UNIVERSIDADE DE SÃO PAULO

FACULDADE DE FILOSOFIA, LETRAS E CIÊNCIAS HUMANAS

DEPARTAMENTO DE LINGUÍSTICA

PROGRAMA DE PÓS-GRADUAÇÃO EM

SEMIÓTICA E LINGUÍSTICA GERAL

\title{
ENTRE DUAS METRÓPOLES: (-R) EM ITANHANDU
}

(Versão corrigida)

MARIANE ESTEVES BIELER DA SILVA

\begin{abstract}
Dissertação apresentada ao Programa de Pós-Graduação em Semiótica e Linguística Geral do Departamento de Linguística da Faculdade de Filosofia, Letras e Ciências Humanas da Universidade de São Paulo para a obtenção do título de mestre em Linguística.
\end{abstract}

Orientador: Prof. Dr. Ronald Beline Mendes

SÃO PAULO

2015 
Ao Dindo (em memória), por todo amor que meu deu.

Ao Marq, por todo o amor que me dá. 


\section{Agradecimentos}

Agradeço à CAPES pelo apoio financeiro indispensável ao longo de 24 meses.

Agradeço ao Professor Ronald Beline Mendes, meu orientador, por ter acreditado em mim desde a iniciação científica e por ter me ajudado nessa caminhada rumo à concretização de meu trabalho de mestrado.

Agradeço aos professores Paulo Chagas e Felipe Venâncio por terem gentilmente aceitado participar de meu exame de qualificação e dado generosas contribuições ao meu trabalho.

Agradeço enormemente à colega Livia Oushiro, sem quem este trabalho seria muitas vezes mais árduo. Agradeço pelas horas gentilmente cedidas para as leituras (e foram muitas) de meu trabalho, para conversas muito produtivas e pela disponibilidade e interesse em me fazer uma pesquisadora cada vez melhor e mais completa.

Agradeço à amiga Marilia por ter me ajudado a manter a saúde mental durante todo esse tempo. Suas conversas sempre bastante realistas (e motivadoras) foram essenciais para que eu não "ficasse pelo caminho". Agradeço também pelas "espairecidas" na Teodoro Sampaio e por sempre estar disposta a ouvir minhas lamúrias com carinho e muita (muita mesmo) paciência.

Agradeço ao amigo Wendel pelas inúmeras risadas e por sempre me botar para cima. Agradeço também pela oportunidade de conhecer um pouco mais do mundo pelo seu olhar, pelo olhar de um nordestino determinado que saiu do Maranhão para buscar seus sonhos em São Paulo.

Agradeço aos amigos Fernando, Larissa, Dayane e Júlia pelas numerosas conversas e trocas acadêmicas e pessoais.

Agradeço a todas as pessoas que fizeram parte desta caminhada, a todos aqueles que me ajudaram nesses dificeis anos em São Paulo e tornaram a minha vida aqui mais confortável e tranquila.

Agradeço muito aos trinta e seis itanhanduenses que, mesmo desconfiando, confiaram em mim e permitiram que eu entrasse em suas casas e gravasse entrevistas com eles. Este trabalho também é de vocês e de todos os itanhanduenses. 
Agradeço aos meus pais, à minha irmã e, sobretudo, à minha mãe, por terem acreditado, mais do que eu mesma, na minha capacidade. Agradeço à minha mãe por ter trabalhado muito para que eu conseguisse realizar o sonho de estudar na Universidade de São Paulo e por não ter deixado que eu me desviasse do propósito de cursar a universidade ao longo desses sete anos da minha estada em São Paulo.

Agradeço ao Marq por sua enorme paciência comigo. Agradeço por sempre ter me dado todo apoio necessário para que eu conseguisse terminar este trabalho e por ter feito com que eu acreditasse mais em mim enquanto pesquisadora e enquanto pessoa.

radeço ao Dindo (em memória) por me fazer conhecer o amor. Quando ele partiu, percebi que o valor da vida está nas pessoas e nas relações que podemos estabelecer com elas. Percebi que DEUS não é um ser superior e inalcançável, mas sim um ente que reside em cada um de nós e faz com que possamos ser cada dia melhores a partir das trocas que fazemos com as pessoas que nos cercam. Muito obrigada, Dindo! 
Quem não passou no Rio Verde de noitinha, não sabe como é bela Itanhandu. Tem sombras debruçadas pela estrada enluarada, tem pomba, tico-tico e tem nhambu.

Quem não rezou junto ao altar-mor da capelinha, Não sabe o que é pecar como eu pequei. Olhando tanta moça bonitinha e amando tanta gente como amei. Mas nunca o meu Brasil foi tão lindo como aqui, aonde canta triste de manhã a juriti. E onde a lua branca é como um simbolo da paz, que vem abençoar Minas Gerais. (Hino de Itanhandu) 


\section{Resumo}

Com base nos pressupostos teórico-metodológicos variacionistas (LABOV, 2006 [1966]; 2008 [1972]; 1999; 2001; 2010) e em alguns conceitos caros à terceira onda (ECKERT, 2012) da Sociolinguística, este trabalho objetiva estudar a comunidade de fala sul-mineira de Itanhandu.

Itanhandu se localiza em uma região de triplice divisa entre os estados de Minas Gerais, São Paulo e Rio de Janeiro. Além dessa posição geográfica singular, os itanhanduenses revelam possuir com as capitais fluminense e paulista uma relação de identificação maior do que possuem com a própria capital de seu estado, o que parece influenciar o falar local, sobretudo na realização de $(-r)$.

O estudo de Itanhandu iniciou-se com uma coleta de 36 entrevistas sociolinguísticas na cidade, que possibilitaram constatar a presença não só de retroflexos, pronúncia considerada a mais prototípica na comunidade, mas também de tepes e fricativos, variantes comumente associadas às capitais de São Paulo e do Rio de Janeiro, respectivamente.

Diante da verificação da ocorrência de tais variantes em Itanhandu, aventou-se a hipótese de que elas estariam correlacionadas aos dois grupos de identificação presentes na cidade, um que se compõe de itanhanduenses que gostam de morar lá e não desejam se mudar ou que tenham saído dela, mas desejam voltar; e outro que se define por itanhanduenses que desejam tentar a vida fora de Itanhandu ou que já se mudaram e não desejam retornar.

Entretanto, a análise quantitativa dos dados mostra que as variantes não prototípicas em Itanhandu estão mais ligadas ao tempo de permanência que os itanhanduenses passaram fora de sua cidade natal, ou seja, pronúncias tepes e fricativas são menos correlatos de uma questão identitária e mais de um fenômeno que se dá naturalmente em um processo de acomodação linguística (GILES, 1973) pelo qual passam os itanhanduenses que moram em outras cidades, principalmente localizadas nos estados de São Paulo e Rio de Janeiro.

Além disso, este trabalho também investiga a existência de graus de retroflexão em Itanhandu. Retroflexos fortes, ou seja, mais duradouros e intensos, opõem-se a retroflexos fracos, ou melhor, mais curtos e com intensidade reduzida. A análise quantitativa dos dados mostra que tal variação correlaciona-se, principalmente, a variáveis linguísticas: são os grupos de fatores Classe Morfológica da Palavra com (-r) e Frequência do Item Lexical com $(-r)$ os que mais explicam a existência de tal fenômeno em Itanhandu.

Por fim, esta dissertação mostra a complexidade da identidade itanhanduense, composta não só de relações sociais, econômicas e linguísticas estabelecidas com cidades paulistas e fluminenses, mas também a partir das vivências individuais dos itanhanduenses, das cidades em que eles já moraram, da forma com que se relacionam com Itanhandu e com os itanhanduenses, das posturas que assumem diante de fatos da vida cotidiana e, principalmente, diante de fatos da realidade linguística da comunidade de fala em que se inserem.

Palavras-chave: Itanhandu. Variação linguística. Identificação com a Cidade. Retroflexo, tepe e fricativo. Graus de retroflexão. 


\section{Abstract}

Based on variationist theory and methods (LABOV, 2006 [1966]; 2008 [1972]; 1999; 2001; 2010), including "third wave" sociolinguistics (ECKERT, 2012), this master's thesis focuses Itanhandu, a town in Southern Minas Gerais, located near the border between Minas Gerais and São Paulo e Rio de Janeiro.

Itanhanduenses tend to identify themselves with the capitais of these two states more than with Belo Horizonte, the capital of Minas Gerais. Such identification has an influence in their local speech, especially when it comes to variable $(-r)$. In a sample of 36 sociolinguistic interviews collected in Itanhandu, there are fricative and tap ocurrences of $(-r)$, aside from the retroflex - which is prototypical in the community. The fricative and tap variants are commonly associated with the capitals São Paulo and Rio de Janeiro, respectively.

The main initial hypothesis is that this case of variation correlates with how Itanhanduenses identify themselves: those who like to live in Itanhandu and do not wish to move to another city (and those who have moved out but would like to return to Itanhandu); and those who would like to leave their birth town (including those who live somewhere else and would not like to move back to Itanhandu).

The quantitative analyses suggest that fricative and tap occurrences of (-r) are less correlated to these subgroups, and more strongly associated with how long a period Itanhanduenses spend outside of their birth town. There seems to be a process of accomodation (GILES, 1973) in the speech of those Itanhanduenses who have lived in other cities, especially in the states of São Paulo and Rio de Janeiro.

This thesis also looks into degrees of (-r) retroflexion. Strong retroflex (lengthier and more intense) and weak retroflex (shorter and less intense) are analyzed as a variable, which correlates more strongly to linguistic factors: Word Class and Word Frequency.

This thesis shows that the Itanhanduense identity is composed not just by social, economic and linguistic relations to São Paulo and Rio de Janeiro, but also by individual experiences, both in Itanhandu itself and in other cities. Such experiences are revealed in stances taken during the sociolinguistic interviews, in relation to facts of their day-to-day life, including their linguistic experiences.

Keywords: Itanhandu. Language Variation. Identification. Retroflex /-r/. Tap /-r/. Fricative /-r/. 


\section{Sumário}

Introdução.

Capítulo 1: Itanhandu

1. A cidade e seus habitantes.

2. O predomínio da pronúncia retroflexa de (-r) em Itanhandu.

2.1. O (-r) em Itanhandu

2.2. Características acústicas do /-r/ retroflexo.

3. A existência de Graus de Retroflexão.

4. Avaliações e percepções sociolinguísticas.

Capítulo 2: Pressupostos Teóricos e Metodologia.

1. Arcabouço teórico

2. Metodologia.

2.1. A construção da amostra

2.2. As entrevistas e os informantes.......................................... 54

2.3. Tratamento dos dados................................................. 57

2.4. Paradigmas da análise quantitativa....................................... 59

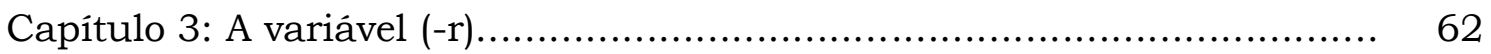

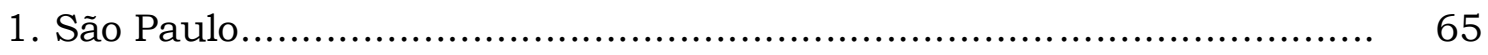

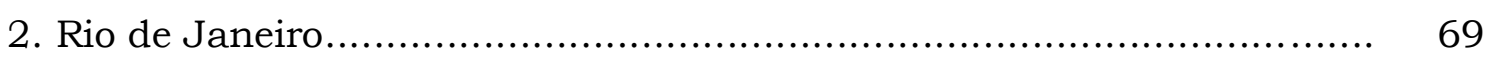

3. Minas Gerais................................................................... 71

3.1. (-r) na Carta 2 do EALMG.............................................. 74

Capítulo 4: Hipóteses de correlação e grupos de fatores....................... 78

1. Variáveis independentes estratificadoras da amostra...................... 78

1.1. Identificação com a Cidade.................................................. 79

1.2. Sexo/gênero............................................................ 82

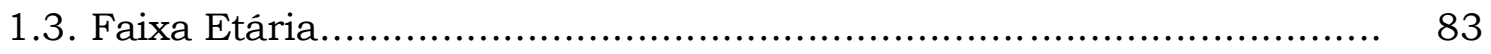

2. Demais variáveis independentes............................................ 84

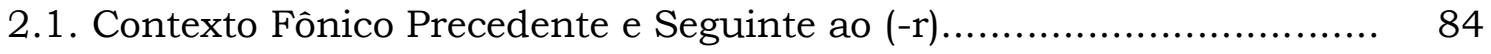

2.2. Posição da sílaba com (-r) em relação à tônica............................. 85

2.3. Posição do (-r) na palavra........................................................ 86 
2.4. Classe Morfológica da palavra com (-r)................................. 86

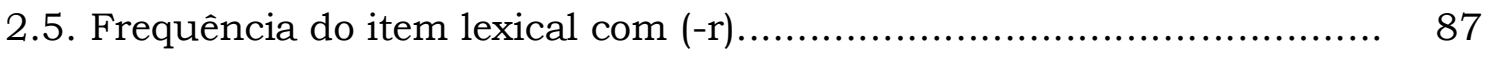

2.6. Parentes fora de Itanhandu ............................................ 88

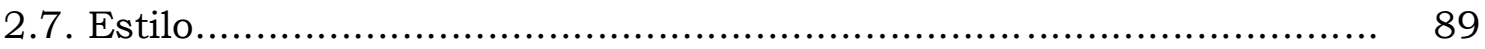

2.8. Tópico Tratado.......................................................... 90

2.9. Tempo Fora de Itanhandu................................................ 91

Capítulo 5: Análises quantitativas........................................... 94

1. Reorganização dos Grupos de Fatores....................................... 95

2. Tepes e fricativos versus retroflexos........................................ 99

2.1. Tempo Fora..................................................................... 102

2.2. Faixa Etária................................................................... 102

2.3. Classe Morfológica da Palavra com (-r)................................... 106

2.4. Tópico Tratado............................................................... 107

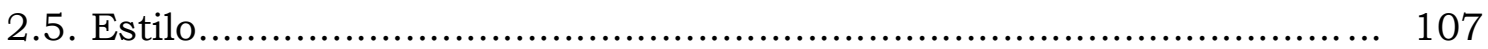

2.6. Sexo/Gênero................................................................. 108

2.7. Contexto Fônico Seguinte ao (-r) .......................................... 111

2.8. Identificação com a Cidade................................................... 112

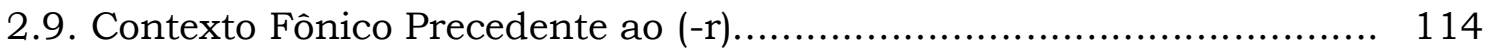

3. Graus de retroflexão....................................................... 114

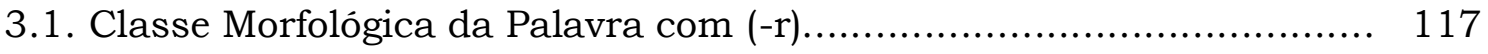

3.2. Frequência do Item Lexical.............................................. 117

3.3. Contexto Fônico Precedente.................................................. 118

3.4. Contexto Fônico Seguinte ao $(-\mathrm{r})$........................................ 119

3.5. Faixa Etária........................................................................ 119

3.6. Demais Grupos de Fatores............................................ 120

Capítulo 6: Análise no Nível do Indivíduo........................................ 122

1. Retroflexos e Tepes............................................................. 124

2. Retroflexos e Fricativos.......................................................... 128

3. Retroflexos, Tepes e Fricativos................................................. 135

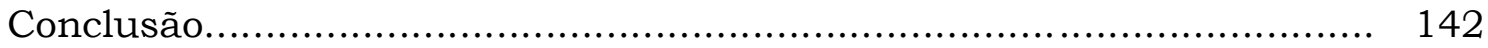

Referências...................................................................... 145 
ANEXO I

ANEXO II.

166

ANEXO III.

169

ANEXO IV

170 


\section{Lista de Tabelas}

Tabela 1: Migração itanhanduense

Tabela 2: Distribuição geral das ocorrências de (-r) em Itanhandu

Tabela 3: Taxas do retroflexo em diferentes amostras em São Paulo (adaptado de OUSHIRO, 2015)

Tabela 4: Vocábulo "arco-íris" no Sul de Minas Gerais

Tabela 5: Distribuição dos informantes de acordo com o Grupo de Fatores Parentes Fora

Tabela 6: Células vazias no cruzamento entre Faixa Etária e Parentes fora de Itanhandu

Tabela 7: Distribuição dos dados de (-r) realizados em Itanhandu

Tabela 8: Grupos de fatores correlacionados à ocorrência de tepes (T) e fricativos $(\mathrm{F})$

Tabela 9: Outros grupos de fatores correlacionados à ocorrência de tepes (T) e fricativos $(\mathrm{F})$

Tabela 10: Cruzamento entre Faixa Etária e Tempo Fora

Tabela 11: Correlação entre Faixa Etária $x$ Tempo Fora e a variável independente

Tabela 12: Cruzamento entre Sexo/Gênero e Tempo Fora com a distribuição dos informantes dentro dos fatores

Tabela 13: Correlação entre o grupo de fatores Sexo/Gênero e Tempo Fora com a variável dependente

Tabela 14: Cruzamento entre Tempo Fora e Identificação com a cidade

Tabela 15: Correlação entre Identificação com a Cidade e Tempo Fora

Tabela 16: Distribuição de retroflexos fortes e fracos em Itanhandu - MG

Tabela 17: Grupos de fatores correlacionados ao (-r) retroflexo fraco

Tabela 18: Outros grupos de fatores correlacionados ao (-r) retroflexo fraco

Tabela 19: Vocábulos mais frequentes na mostra itanhanduense

Tabela 20: Distribuição dos informantes por ocorrência de (-r) realizado 


\section{Lista de Quadros}

Quadro 1: Variáveis estratificadoras das entrevistas coletadas entre 20102012

Quadro 2: Variáveis estratificadoras da amostra itanhanduense

Quadro 3: Informantes da amostra itanhanduense

Quadro 4: Grupos de Fatores incluídos na análise

Quadro 5: Resumo dos grupos de fatores

Quadro 6: Reorganização dos grupos de fatores 


\section{Lista de Figuras}

Figura 1: Divisão do estado de Minas Gerais em zonas para a coleta dos dados do EALMG (RIBEIRO et al., 1977)

Figura 2: Isoglossas delimitadas pelo Atlas Linguístico do Estado de Minas Gerais (ALEMIG)

Figura 3: Microrregiões de Minas Gerais segundo divisão do IBGE

Figura 4: Localização de Itanhandu em relação ao Rio de Janeiro, a São Paulo e a Belo Horizonte

Figura 5: Itanhandu e região

Figura 6: Número de migrações em Itanhandu, Itamonte e Passa Quatro

Figura 7: Dados da economia itanhanduense

Figura 8: Forma da onda e espectrograma da sequência "redor pra e" na sentença "digo redor pra ele" (FERRAZ, 2005)

Figura 9: /-r/ considerado forte

Figura 10: /-r/ considerado fraco

Figura 11: Adjetivos atribuídos ao "falar itanhanduense"

Figura 12: Diferenças entre o falar itanhanduense e o carioca

Figura 13: Diferenças entre o falar itanhanduense e o paulistano

Figura 14: Tabela gerada pelo RStudio

Figura 15: Exemplo de codificação dos dados feita no Microsoft Excel 2010

Figura 16: espectrograma da sequência "portu" retirada do vocábulo "portugueses"; traçado de forma da onda corresponde a (a), espectrograma de banda larga corresponde a (b) e transcrição ortográfica corresponde a (c) (GRECIO, 2012: 87)

Figura 17: espectrograma do vocábulo "por"; traçado de forma da onda corresponde a (a), espectrograma de banda larga corresponde a (b) e transcrição ortográfica corresponde a (c) (GRECIO, 2012: 88)

Figura 18: Mesorregiões do Estado de Minas Gerais

Figura 19: Carta 2 - ocorrência do vocábulo "arco-íris"

Figura 20: Carta 47 - região isófona da variante retroflexa

Figura 21: Correlação entre faixa etária e a pronúncia de (-r) como tepe ou fricativo 
Figura 22: Resultados quantitativos para o cruzamento entre Faixa Etária e Tempo Fora

Figura 23: Cruzamento entre Sexo/Gênero e Tempo Fora

Figura 24: Resultados para a correlação entre Identificação com a Cidade e Tempo Fora com a variável dependente

Figura 25: Correlação entre Faixa Etária e (-r) retroflexo 


\section{Introdução}

No Brasil, já foram realizados muitos estudos sociolinguísticos sobre a pronúncia variável de $(-\mathrm{r})^{1}$ (ROSSI et al., 1963; ZÁGARI, 2005 [1977]; ARAGÃO; MENEZES, 1984; CALLOU, 1987; FERREIRA et al., 1987; CALLOU; MORAES; LEITE, 1996; KOCH et al., 2002; CRUZ, 2004; RAZKY, 2004; LIMA, 2006; BRANDÃO, 2007; PEREIRA, 2007; BRESCANCINI; MONARETTO, 2008; MENDES, 2010; LOURDES, 2011; MENDES; OUSHIRO, 2012, OUSHIRO, 2015, entre outros), sobretudo em contexto pós-vocálico medial e final. O interesse por tal variável linguística evidencia sua relevância como marca regional: os diferentes trabalhos aqui citados foram realizados em vários estados brasileiros com o intuito geral de caracterizar sociolinguisticamente cada região.

Segundo Ladefoged e Maddieson (1996), as principais variantes róticas são: vibrantes, tepes ${ }^{2}$, fricativas e aproximantes. As vibrantes, consideradas pronúncias róticas prototípicas por estes autores, são produzidas a partir da vibração da ponta da língua contra a região dental/alveolar ou a partir da vibração da úvula contra a região dorsal da língua. Os tepes resultam de um breve contato entre a ponta da lingua e a região dental ou alveolar. As fricativas são resultantes de uma estreita constrição em algum ponto específico do trato vocal; no caso das fricativas velares, ocorre uma fricção da parte posterior da língua no palato mole, já nas fricativas glotais, são os músculos da glote que se movimentam e causam a fricção. Por fim, as aproximantes são sons produzidos não pelo contato entre os articuladores, mas apenas pela aproximação entre eles, as aproximantes alveolares são produzidas pela aproximação entre o ápice/lâmina da língua e os alvéolos; enquanto as aproximantes retroflexas resultam da realização do som com a ponta da lingua voltada para a parte posterior do trato vocal.

\footnotetext{
${ }_{1}^{1}$ Seguindo Labov 2008 [1972], adota-se a notação “(-r)” para fazer referência à variável sociolinguística.

${ }^{2}$ Os autores fazem distinção entre tepes e flaps, mas, seguindo Lindau (1985) e outros linguistas, essa diferenciação não foi considerada.
} 
A reunião dos diferentes sons de $/ \mathrm{R} /{ }^{3}$ em um mesmo grupo baseia-se no que Lindau (1985) chama de "semelhança de família", ou seja, na semelhança que alguns subgrupos, que formam tal classe, compartilham entre si e no fato de serem todos representados pela mesma letra ' $r$ '.

Embora haja alguns subgrupos de sons (vibrantes, tepes, etc) incluídos na classe dos róticos, no geral, a unidade da classe parece residir principalmente nas conexões históricas entre estes subgrupos e na escolha da letra ' $r$ ' para representar todos eles. (LINDAU, 1985 apud LADEFOGED; MADDIESON, 1996: 245).

Em posição de coda silábica no Português Brasileiro (doravante PB), a pronúncia fricativa é, de modo geral (CALLOU et al., 1996; SILVA, 2002; BARBOSA; ALBANO, 2004; GRECIO, 2012), atribuída aos falantes do Rio de Janeiro (cidade e estado), Belo Horizonte e cidades da região nordeste, como Salvador e Recife. A variante tepe, por sua vez, associa-se à cidade de São Paulo (OUSHIRO, 2015) e a Porto Alegre. A variante vibrante aparece em algumas regiões do estado de São Paulo e nas regiões do sul do país. Finalmente, a variante retroflexa aparece relacionada ao interior de São Paulo, Norte do Paraná, Mato Grosso do Sul e sul de Minas Gerais. Esta última região é o foco de interesse do presente trabalho.

Quanto à origem da variante retroflexa, Aguilera e Silva (2011) apontam a hipótese de que teria surgido do contato entre o português e o tupi, língua que não apresenta os fonemas /1/ e /r/ em coda silábica. Assim, os indígenas, devido à dificuldade com a realização lusitana do /1/ alveolar e velar em coda silábica em contexto CVC, como nas palavras mal e sol, e em uma tentativa de aproximar a lâmina da língua para a produção de tal som, poderiam ter dado início ao (-r) retroflexo. Segundo as autoras: "Tal fone teria se formado entre os paulistas, mamelucos e indígenas e se irradiado pelos territórios conquistados e ocupados pelos bandeirantes no século XVII e XVIII” (2011: 126).

Como pode ser percebido na divisão dialetal proposta por Nascentes (1953), o estado de Minas Gerais é bastante diverso no que diz respeito aos seus usos e costumes linguísticos no geral, mas também no tocante à variável

3 Tal notação é utilizada para se referir ao arquifonema $R$, aquele que congrega os diferentes sons relacionados a tal fonema no Português Brasileiro. 
(-r). A classificação linguística que vale para o norte de Minas modifica-se para o centro e também para o sul do estado. Dessa forma, mostra-se bastante difícil, como afirmara Serafim da Silva Neto (1963), determinar isoglossas dentro do território nacional e, especificamente, dentro do estado de Minas Gerais.

Com o objetivo de compor o que foi denominado Esboço de um Atlas Linguístico de Minas Gerais (EALMG), os professores José Ribeiro e Mário Roberto Zágari (UFJF), na década de 1970, coletaram dados por meio de questionários em 116 municípios mineiros distribuídos por todo o estado, somando, ao fim da pesquisa, mais de 6.000 horas de gravação.

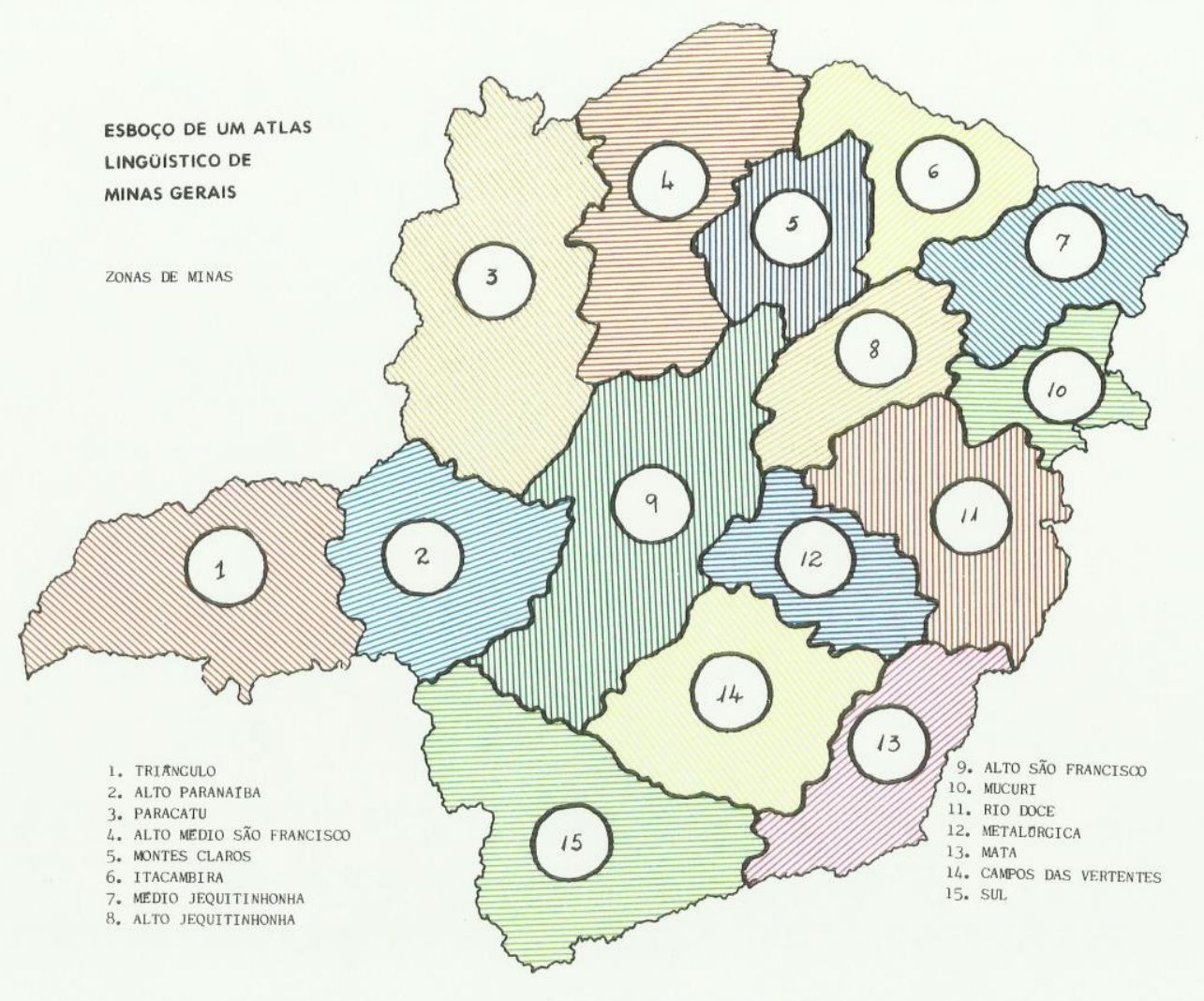

Figura 1: Divisão do estado de Minas Gerais em zonas para a coleta dos dados do EALMG (RIBEIRO et al.,1977)

O questionário elaborado era composto de 415 perguntas, pelas quais caberia aos informantes indicar não só o modo como pronunciavam determinadas palavras, mas também suas preferências lexicais acerca de 5 campos semânticos: tempo e folguedos infantis, homem, animais, água e terra. As entrevistas foram semidirigidas, ou seja, os entrevistadores dispunham de um conjunto fechado de perguntas que deveriam ser 
respondidas pelo informante, tendo este a liberdade de responder às perguntas conforme lhe conviesse.

Com tal estudo, os pesquisadores chegaram a uma divisão do estado em 3 sub-regiões. Ao norte do estado, os costumes linguísticos foram aproximados aos do estado da Bahia (com o qual Minas faz divisa). Segundo Zágari (1996), nessa região há

(...) predominância de vogais baixas, quando pretônicas, como

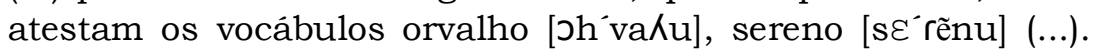
Outro fato fonético não menos importante é a presença das africadas [t $\mathrm{t}]$ ou [d $\mathbf{3}$ ] como se visualiza em ['mutfu], ['ot $\left.\int \mathrm{u}\right]$ (...). Esse alteamento, essa fricativização é exclusiva dessa região e fica, em Minas, circunscrita àquela fronteira, notando-se, apenas, que, à medida em que se elevam os estratos sociais vai-se diminuindo, sem desaparecer, o grau de incidência da regra que faz altear o [d] e o [t] imediatamente após a vogal alta anterior. (Zágari, 1996:16-17)

As cidades que compõem a região do Triângulo Mineiro e o Sul de Minas foram caracterizadas pela presença marcante da pronúncia retroflexa de (-r), produção que se aproxima do que se verifica no interior do estado de São Paulo. Mais uma vez, a situação de divisa estadual pareceu contribuir para a explicação das produções linguísticas observadas.

Já a região central de Minas Gerais seria um contraponto às duas anteriores, por revelar características peculiares do "falar mineiro" (NASCENTES, 1958; ZÁGARI, 1996). Segundo estudos do grupo de Variação Fonético-Fonológica em Minas Gerais (VarFon-Minas) da Faculdade de Letras (FALE) da UFMG (PAES, 2014) e também seguindo o estudo de CristófaroSilva (2008), a pronúncia variante mais comum de (-r) nessa região é a fricativa glotal. 


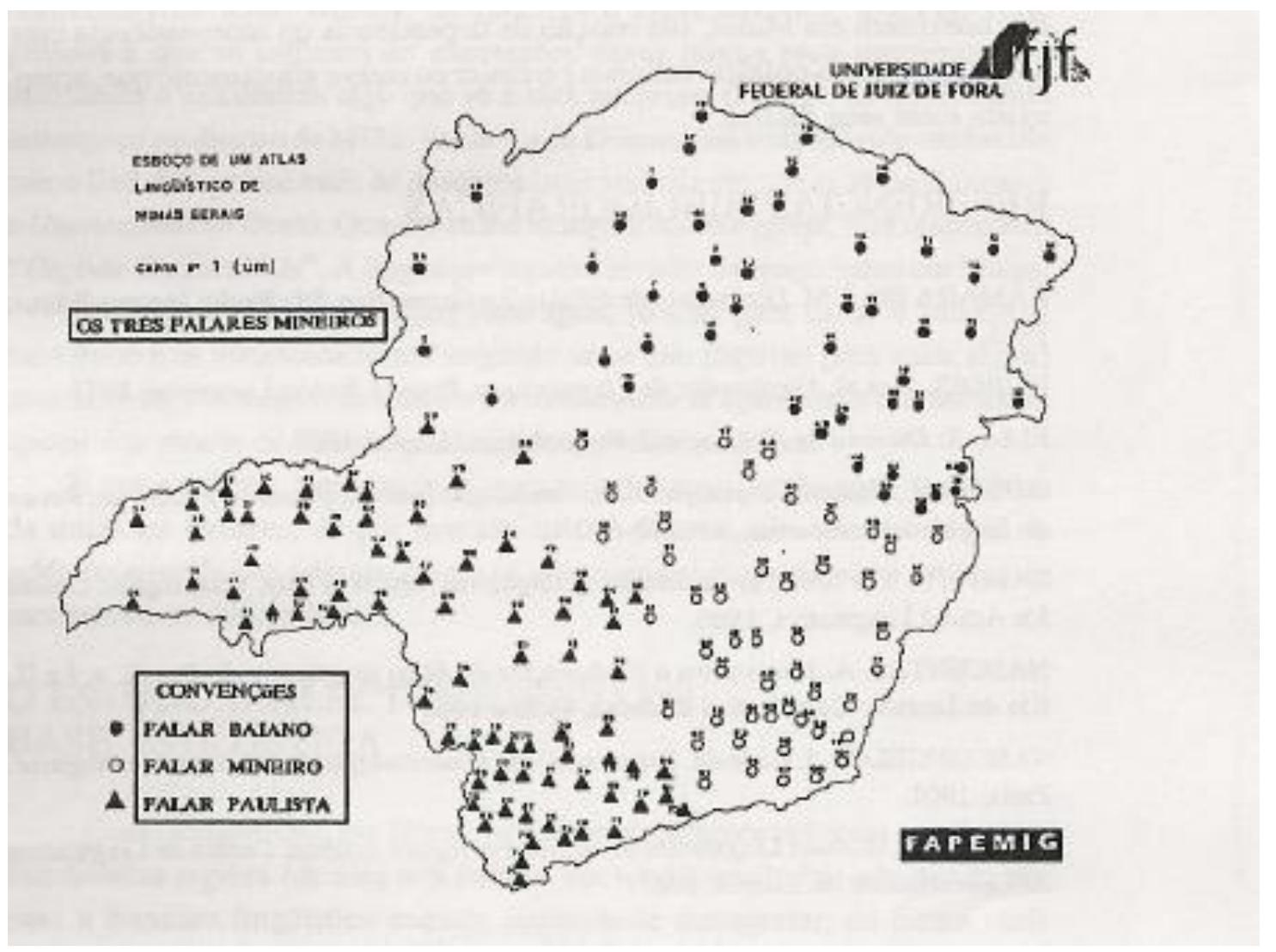

Figura 2: Isoglossas delimitadas pelo Atlas Linguístico do Estado de Minas Gerais (ALEMIG) - (ZÁGARI, 1998: 46)

O estudo de Ribeiro et al. (1977), apesar de bastante abrangente (já que contemplou dezenas de cidades espalhadas por todo o estado de Minas Gerais), permite entrever problemas em algumas generalizações. Os pesquisadores observaram que os costumes linguísticos de determinadas regiões do estado pareciam ter ligação com outros estados ou regiões, com os quais Minas faz divisa - com exceção do centro do estado, aparentemente imune a influências externas (daí a percepção de que seria esta a região mais “autenticamente mineira”).

Um aparente equívoco, contudo, foi desconsiderar Rio de Janeiro, Espírito Santo, Goiás, Distrito Federal e Mato Grosso do Sul, demais estados com os quais Minas Gerais também faz divisa, como outros possíveis influenciadores dos falares mineiros, sobretudo na realização do (-r).

Segundo afirma Martins (2006), os equívocos decorrentes das generalizações propostas por Ribeiro et al. (1977) - tal como classificar indistintamente todo o sul de Minas como "falar apaulistado" (devido à "presença marcante" do retroflexo) - seriam resultado de uma dificuldade que os dialetólogos encontram para limitar as zonas de ocorrência de um 
determinado traço fonético ou gramatical de um falar. No caso da variação linguística em Minas, como ocorre via de regra, não há como demarcar as fronteiras dessas três regiões dialetais de forma definitiva, no sentido de se verificar onde começa uma e acaba outra, pois as zonas limitrofes estão em constante contato.

O trabalho que aqui se apresenta evidencia tal dificuldade, uma vez que o estado do Rio de Janeiro também se mostra como influenciador da fala itanhanduense, objeto de estudo desta pesquisa.

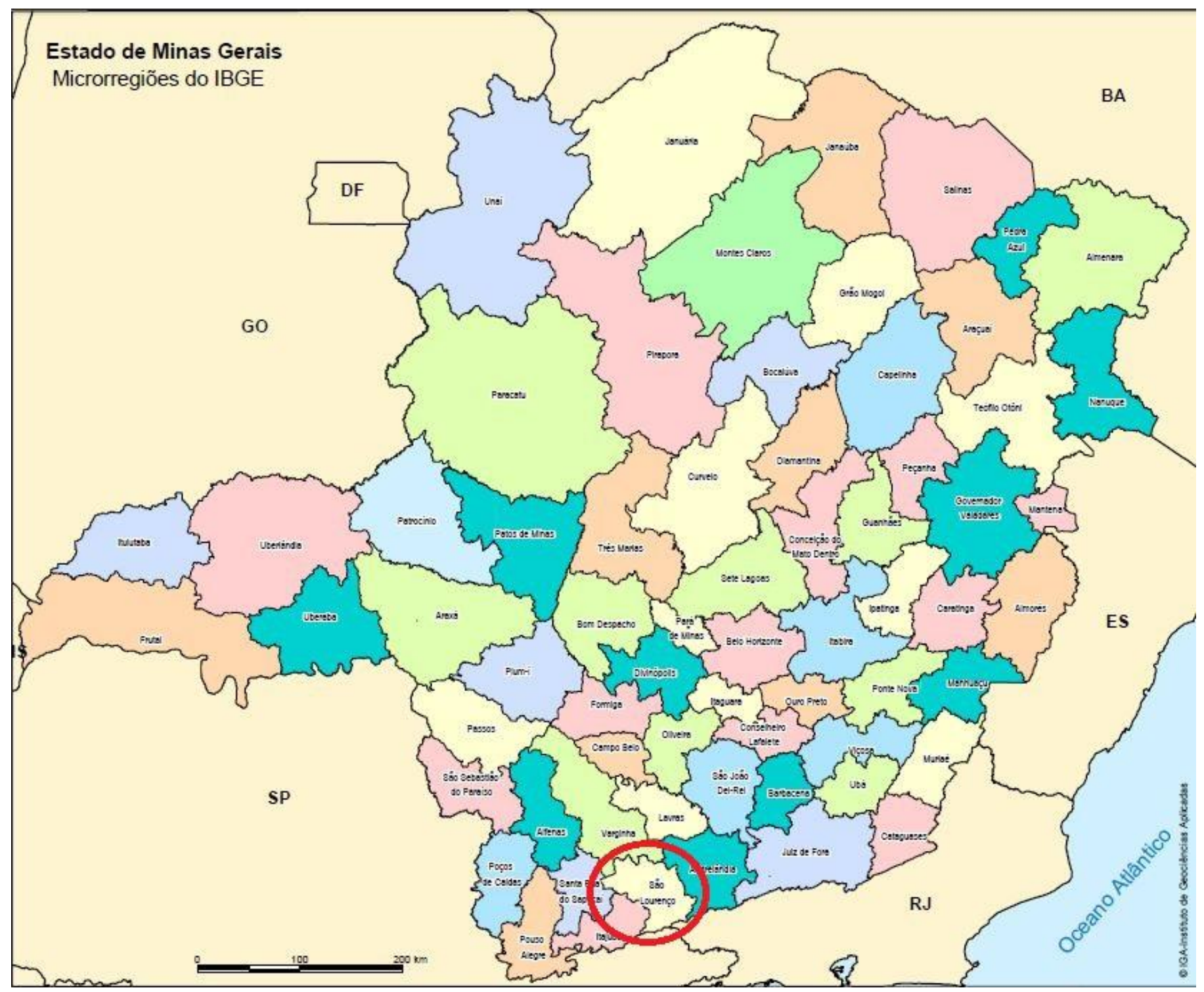

Figura 3: Microrregiões de Minas Gerais segundo divisão do IBGE ${ }^{4}$

${ }^{4}$ Disponível em: http://www.iga.br/SiteIGA/mapas/cgi/Imagens/MG_microColor.pdf Último acesso em 08 de Abril de 2015. 
Itanhandu localiza-se na microrregião de São Lourenço (Figura 3) e revela-se como uma sorte de evidência do equívoco anteriormente apontado. Por sua localização, em princípio, entender-se-ia que compartilha do "falar apaulistado". Esta pesquisa mostrará que não há dúvidas de que os itanhanduenses pronunciam o (-r) de maneira retroflexa a maior parte do tempo. Contudo, vai chamar atenção para o fato de que a região onde se localiza Itanhandu está numa área de divisa não só com o estado de São Paulo, mas também com o estado do Rio de Janeiro. Talvez por esse fato, itanhanduenses também pronunciem o (-r) de maneira fricativa - um fato linguístico que não é comumente associado ao estado de São Paulo ou ao Sul de Minas.

Além disso, interessa notar que a influência dos costumes linguísticos cariocas e paulistas no falar itanhanduense parece ser mais presente do que a influência do falar belorizontino (com sua ausência de ditongação em vogais finais sucedidas de sibilantes, com em ['nos] e com sua prosódia característica).

Esse fato parece decorrer da localização de Belo Horizonte - bem mais distante de Itanhandu do que as duas maiores metrópoles brasileiras (ver Figura 4). Além da questão geográfica, parece haver em Itanhandu uma relação identitária complexa que os habitantes desenvolvem com as capitais fluminense e paulista e não com a capital mineira. É comum o trânsito de itanhanduenses para as duas maiores metrópoles brasileiras, a fim de fazer compras, ir a médicos, visitar parques e exposições e também para estudar em suas universidades. Dessa forma, parece que os itanhanduenses desenvolvem uma identificação com Rio de Janeiro e São Paulo que por vezes parecem não desenvolver com Belo Horizonte. 


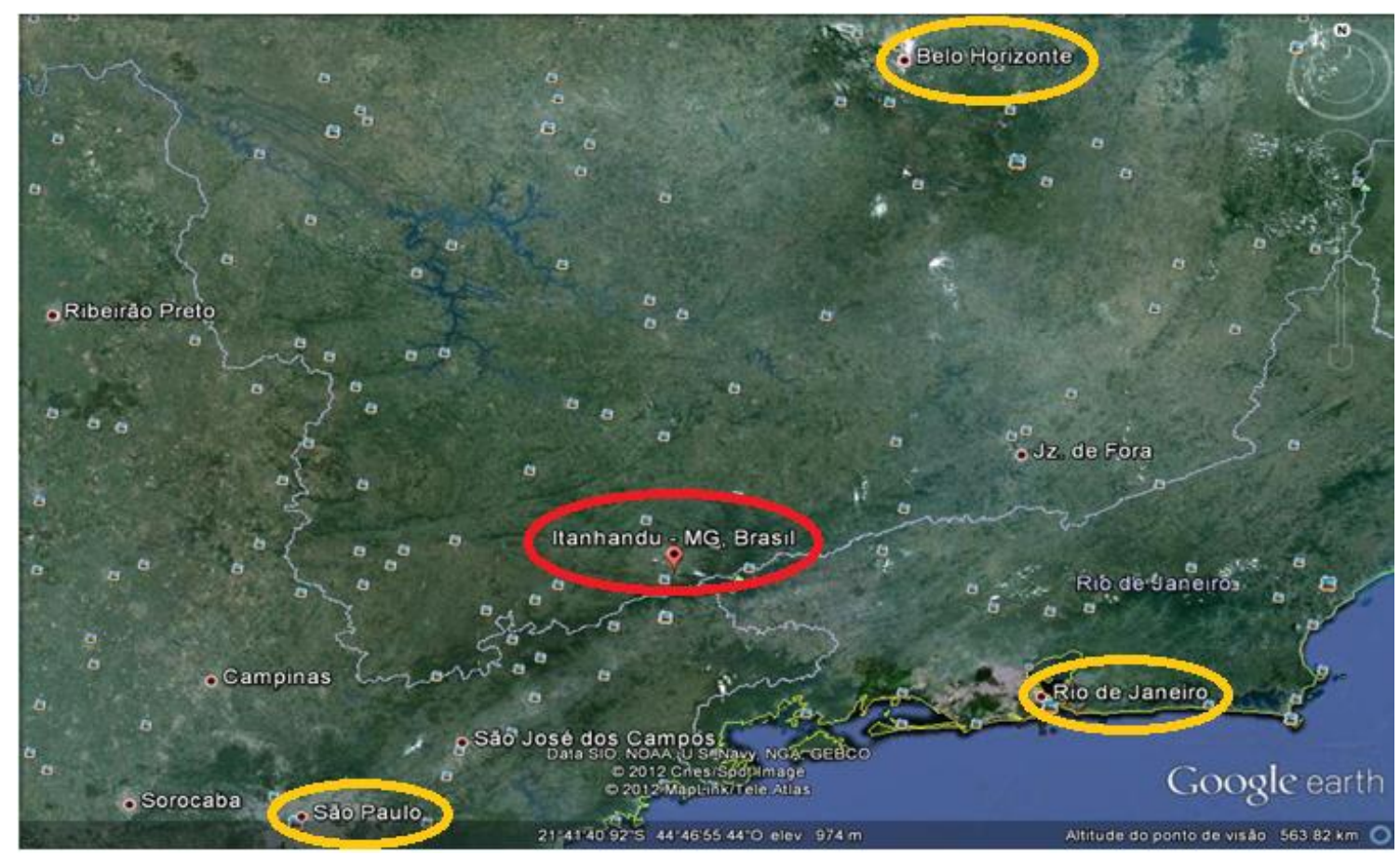

Figura 4: Localização de Itanhandu em relação ao Rio de Janeiro, a São Paulo e a Belo Horizonte 5

Outra consideração a se fazer é que não só estados como um todo parecem influenciar os falares mineiros, mas também cidades específicas. Esse parece ser o caso da capital paulista que, possivelmente por sua proximidade em relação a Itanhandu e por sua maior relação (social e econômica) com a cidade, parece ter influência sobre o falar local dos itanhanduenses: é notável a ocorrência da pronúncia tepe na cidade.

Considerando-se que se trata de uma cidade do Sul de Minas, essas pronúncias não prototípicas de (-r) (tepes e fricativas) parecem destacar-se, na medida em que se tem o que se chama aqui de "expectativa dialetológica" de que a "única" variante de (-r) ali realizada seria a retroflexa.

Dessa foram, interessa ao presente estudo investigar a pronúncia de $(-\mathrm{r})$ em posição de coda medial e final como retroflexo, tepe ou fricativo em Itanhandu. Para isso, analisaram-se 36 entrevistas sociolinguísticas gravadas nessa cidade sul-mineira entre 2010 e 2013. Os informantes foram estratificados de acordo com: (i) seu sexo/gênero; (b) sua faixa etária (18 a 30 anos; 31 a 45 anos; 46 anos ou mais) e (c) sua identificação com a cidade.

\footnotetext{
${ }^{5}$ A distância entre Itanhandu e Rio de Janeiro é de $225 \mathrm{Km}$; de Itanhandu a São Paulo são $255 \mathrm{Km}$ e, finalmente, de Itanhandu a Belo Horizonte tem-se $348 \mathrm{Km}$.
} 
Esta última variável divide os itanhanduenses em dois grupos: (A) aqueles que moram na cidade e não desejam sair ou que, morando fora, desejam voltar e (B) itanhanduenses que desejam deixar a cidade ou, uma vez já morando fora, não desejam retornar a ela.

O estabelecimento desse grupo de fatores foi uma tentativa de objetivar as relações identitárias que os itanhanduenses mantêm com a cidade de que são naturais e com cidades com as quais possuem estreita relação social e econômica, com destaque para São Paulo e Rio de Janeiro.

As pronúncias de $(-r)$ foram codificadas como: retroflexas $(R)$, fricativas $(\mathrm{H})$, tepes (T). Marcaram-se ainda os casos de apagamento (A) e de "usos metalinguísticos" $(\mathrm{M})$, casos que não representavam uma realização autêntica desse elemento fônico, por vezes uma imitação de falantes de outras localidades. Os casos de apagamento e usos metalinguísticos foram descartados das análises quantitativas.

Os exemplos (1), (2) e (3) abaixo trazem ocorrências de (-r) na amostra da fala itanhanduense ${ }^{6}$, marcadas de acordo com os códigos acima:

D1: por que você acha que o computador ele atrai tanto assim

S1: mas ele

D1: o mundo virtual?

$\mathrm{S} 1$ : é o mundo virtual $<R>$ pois no computador $<R>$ tem tudo que eles querem no computador $<R>$ tem músicas tem jo/jogos (F3A_rose) ${ }^{7}$

$\mathrm{S} 1$ : a cidade é fria... é fria porque $<H>$ pela distância das pessoas

D1: aham

S1: mas...

D1: como que é morar na cidade... que é sede administrativa do país assim?

S1: normal $<H>$

D1: que é bem diferente daqui né

S1: é normal $<H>$ é porque $<A>$ a sede administrativa é do país (M3B_leonardo)

\footnotetext{
${ }^{6}$ Os áudios estão disponíveis no CD anexo ao trabalho.

${ }^{7}$ Os informantes foram identificados de acordo com seu sexo/gênero (M para homens e F para mulheres); sua faixa etária (1 para a primeira faixa etária, que vai de 18 a 30 anos; 2 para a segunda, que vai de 31 a 45 anos; e 3 para a terceira, que abarca pessoas de 46 anos ou mais) e seu grupo de identificação (A para maior identificação com a cidade e B para menor identificação com a cidade).
} 
S1: tipo que nem lá em Vassouras eu tinha muito contato com as meninas eu ia para a casa delas... mas parece que não era a mesma coisa

D1: uhum

$\mathrm{S} 1$ : entendeu? você tem aquela amizade assim mas você acha que não vai durar $\angle A>\ldots$ porque $\langle T>$ você sabe que daqui a quatro anos acaba vai ser $\langle A>$ difícil de se ver $\langle A>$ complica (F1B_heloísa)

(4)

D1: você acha que dá para perceber $<R><A>$ pelo sotaque também que a pessoa tem?...

$\mathrm{S} 1:$ então... eu [hes.] assim dá para perceber pelo sotaque sim

D1: uhum

S1: só que tem muita gente que pega muito fácil sotaque

D1: ah entendi

S1: né e outra coisa o [hes.] nosso sotaque aqui... o pessoal acha que mineiro que fala 'leite' ['t' na forma oclusiva alveolar] [risos - D1] 'porta' $\langle M>$ [erre retroflexo exagerado] 'portão' $<M>$ [erre retroflexo exagerado] 'porteira' $<M>$ [erre retroflexo exagerado] e não é D1: uhum

S1: isso é interior de São Paulo [S1 bate na mesa]

Embora os trechos acima tragam concentrações de uma ou outra variante, esse fato é menos comum nas entrevistas coletadas com os itanhanduenses para esta pesquisa, nas quais é frequente a ocorrência das três variantes num mesmo momento da conversa. O interesse principal dessa pesquisa é, de fato, verificar: de que maneira as relações que os itanhanduenses estabelecem com Itanhandu, mas também com São Paulo e Rio de Janeiro, influenciam a ocorrência de tepes e fricativos na sua fala?

A dissertação se organiza em seis capitulos. O Capítulo 1 apresenta Itanhandu, um pouco da sua história e economia, bem como aspectos que se mostram fundamentais para o entendimento dos fatos linguísticos observados nessa cidade. Traz também algumas considerações sobre as produções de (-r) em tal comunidade de fala e discute questões linguísticas e sociais locais a partir do próprio "discurso" dos itanhanduenses. Por fim, o capítulo traz as percepções e avaliações dos itanhanduenses sobre seu próprio falar, sobre o falar carioca e paulistano e sobre a variante retroflexa.

O Capítulo 2 dedica-se aos fundamentos teóricos e metodológicos da análise: as premissas da Sociolinguística Variacionista, o que se vem chamando de "ondas da Sociolinguística" (ECKERT, 2012) e paradigmas de análise quantitativa multivariada com o uso do pacote estatístico GoldVarb X (ROBINSON; LAWRENCE; TAGLIAMONTE, 2001). Além disso, o capítulo apresenta o passo a passo da metodologia utilizada na coleta, transcrição e análise dos dados.

O Capítulo 3 revisa trabalhos já desenvolvidos sobre a pronúncia de (-r), iniciando-se por alguns trabalhos seminais sobre o tema, passando pelo 
tratamento dessa variante no Brasil até chegar a estudos mais recentes sobre o rótico em posição de coda silábica.

O Capítulo 4 apresenta a amostra de dados e os grupos de fatores linguísticos e extralinguísticos (variáveis independentes) estabelecidos para as análises de correlação com a variável dependente, ou seja, desenvolve as análises qualitativas dos dados do envelope de variação que se define, justificando-se as hipóteses aventadas sobre a variável (-r).

O Capítulo 5 traz as análises quantitativas e a discussão dos resultados. Apresentam-se duas análises quantitativas distintas: (1) retroflexos versus tepes e fricativos; (2) retroflexos fortes versus retroflexos fracos. As justificativas para essas duas análises se desenvolvem ao longo do trabalho.

Por fim, o Capítulo 6 expande as análises, com foco nos informantes que apresentam maior taxa de realização de tepes e fricativos, visando a explicar esses usos, vistos como dialetologicamente "externos" à realidade linguística sul-mineira. 


\section{Capitulo 1: Itanhandu}

1. A cidade e seus habitantes

O município sul-mineiro de Itanhandu - onde vivem aproximadamente 14 mil pessoas (IBGE, 2010) - foi oficializado como tal em 7 de setembro de 1923. Teve suas origens com um pequeno aglomerado de casas no século XVIII, circundado por várias fazendas - o arraial da Barra Verde (IBGE). ${ }^{8}$

Segundo dados do IBGE,

Acerca do nome Itanhandu, que serve desde tempos remotos de denominação ao ribeirão que nasce no município e conflui com o rio Verde nos mesmos limites, constam referências nos anais da Diocese de Campanha datados do século XVIII.

Obscura é a origem do nome do ribeirão Itanhandu, único vestígio dos primórdios do núcleo inicial de longínqua era; quanto à toponímia, conhecidos tupinólogos fazem a seguinte definição: "ita" (pedra) - "nhandu" (ema): - pedra da ema ou pedra da avestruz, segundo tradução de Alfredo de Carvalho. (...) Correndo venturoso o ano de 1882, o promissor arraial da Barra do Rio Verde - mais tarde Estação de Capivari e, hoje Itanhandu - viu atendida uma das suas aspirações, assistindo festivamente à chegada das primeiras turmas de ferroviários, vindos para darem início aos trabalhos de construção das linhas da Estrada de Ferro Minas e Rio, hoje Rede Mineira de Viação.

É a partir da chegada da linha ferroviária Minas/Rio que Itanhandu começa a se desenvolver economicamente. Atualmente, a cidade vive da agropecuária, indústria e serviços.

\footnotetext{
8 Disponivel em:

<http://www.ibge.gov.br/cidadesat/painel/painel.php?codmun=313310\&search=min as-gerais |itanhandu\#historico > Último acesso em 08 de Junho de 2015.
} 


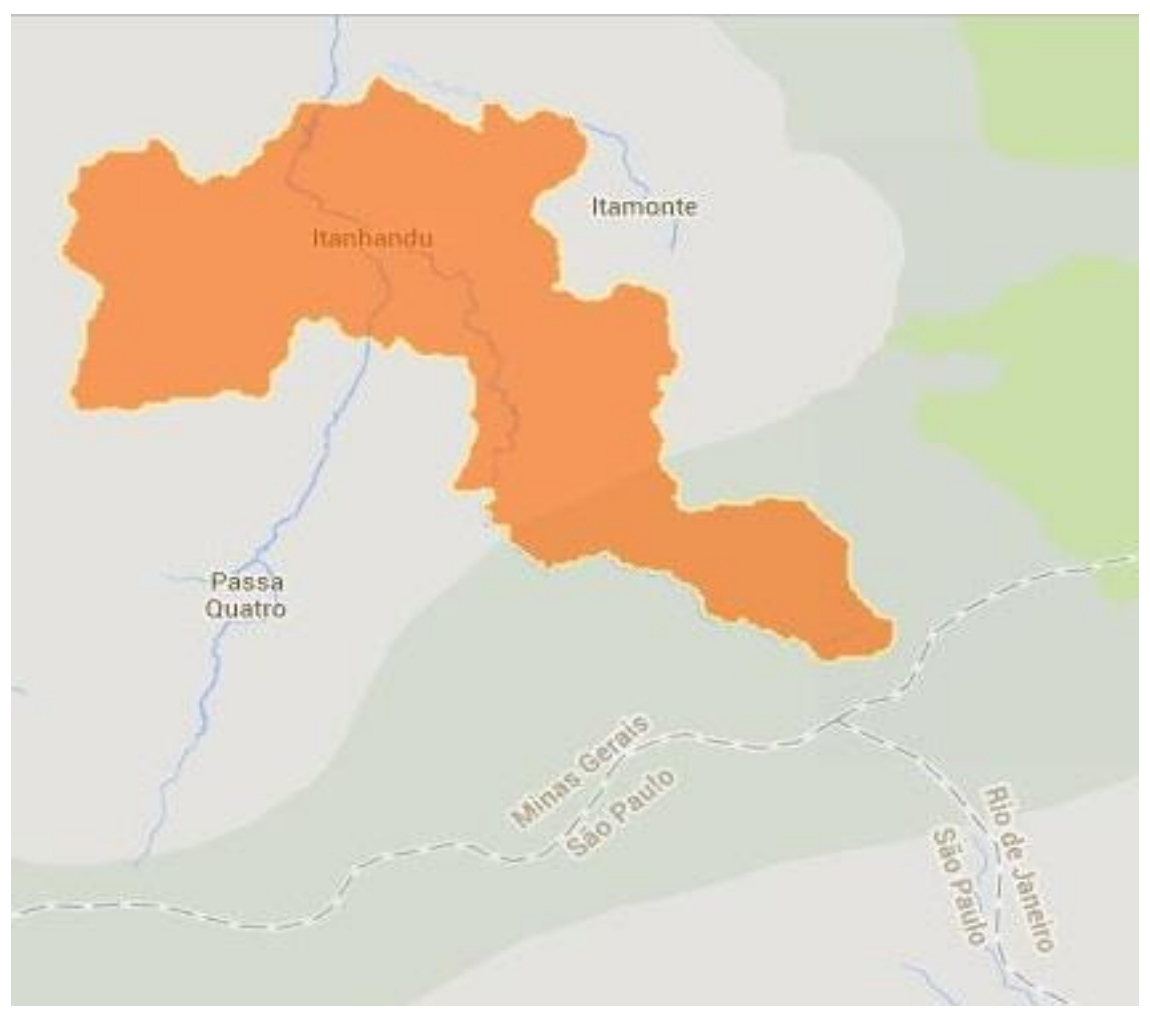

Figura 5: Itanhandu e região9

Pacata, pequena e culturalmente rica, Itanhandu fica próxima à divisa entre os estados de Minas Gerais, São Paulo e Rio de Janeiro (Figura 5) e congrega características culturais, sociais e linguísticas dos três estados.

Em muitas entrevistas, os itanhanduenses destacam a localização geográfica da cidade como uma de suas qualidades. No trecho abaixo, é possivel observar que, para a informante, ao lado da tranquilidade, do fato de possuir boas escolas e bons médicos, a posição geográfica de Itanhandu é amplamente valorizada. Também fica perceptível a relação mais próxima de Itanhandu, localizada no estado de Minas Gerais, e de seus habitantes com os estados de São Paulo e Rio de Janeiro, e suas respectivas capitais.

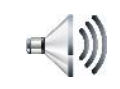

S1: moramos pertinho de Rio e São Paulo... que você qualquer coisa você sai e chega lá em... três horas no máximo em três horas

D1: você acha que é maior o contato com Rio de Janeiro e São Paulo do que com \{Belo Horizonte que é a nossa capital?\}

\footnotetext{
9 Disponivel em:

$<$ http:/ / cidades.ibge.gov.br/painel/painel.php?lang=\&codmun=313310\&search=mina s-gerais | itanhandu |infograficos:-dados-gerais-do-municipio> Acesso em 08 de Junho de 2015.
} 
S1: \{muito mais ué\} pois eh Belo Horizonte eh [hes.] eu fui conhecer Belo Horizonte eu já era casada [risos - D1] tinha minhas duas/ meus dois filhos... aqui eu eu eu conheço o Rio desde que eu tinha três anos de idade

D1: é verdade...

S1: Belo Horizonte é longe demais... \{para a gente\}

D1: \{você acha\} que a gente que a gente tem menos contato com Belo Horizonte porque é longe ou porque a gente se identifica menos com Belo Horizonte?

$\mathrm{S} 1$ : eu acho que a gente se identifica menos exatamente porque é longe

D1: uhum

S1: né...

D1: entendi

$\mathrm{S} 1$ : até o jeito de falar de belorizontino é diferente do nosso daqui do sul de Minas (F3A_rose)

Sobre a influência paulista/paulistana ${ }^{10}$ e carioca na cidade de Itanhandu, a informante Lorena afirma:

S1: eu acho que é uma influência muito grande de São Paulo né

D1: uhum

S1: São Paulo é um dos países mais ricos do [hes.] do do

D1: uhum

S1: dos paises

D1: um dos estados

S1: é um dos estados mais ricos aqui do do Brasil

D1: uhum

S1: então a gente tem muita influência de São Paulo

D1: entendi

S1: e tem a... uma marrentice do Rio né [risos - D1] então juntou (F2B_lorena)

É para São Paulo e Rio de Janeiro, e também para suas capitais, que Itanhandu "exporta" a maioria de seus migrantes. Entre os 36 itanhanduenses entrevistados, 21 deles (ou seja, 58\%) possuem parentes (considerados pais ou irmãos) que vivem fora de Itanhandu. Quinze entrevistados possuem parentes morando ou no estado de São Paulo ou no estado do Rio de Janeiro, 6 deles possuem parentes em outras cidades de Minas Gerais, 1 possui parente em Goiás, 1 em Brasília e 1 no estado do Pará.

Em alguns casos, como o mesmo informante possui mais de um parente morando fora, a quantidade de pessoas que deixaram a cidade supera a quantidade de itanhanduenses entrevistados que possuem familiares em outras cidades que não Itanhandu.

São reconhecidamente numerosos os jovens e adultos (Tabela 1 abaixo) que deixam sua cidade de origem em busca de melhores condições de vida, de

10 Os itanhanduenses usam, muitas vezes, indistintamente os adjetivos "paulista" e "paulistano" para se referir ora ao estado de São Paulo ora à cidade de São Paulo. 
instituições de ensino de maior mérito e de melhores empregos. Aproximadamente $10 \%$ dos itanhanduenses não moram em sua cidade natal. A esse respeito, o informante Gustavo explica:

D1: você gostava de morar aqui na época que você morava?...

S1: eu gostava... eu gostava sim... eu senti necessidade porque [hes.] de sair daqui... mais é por estudo sabe?

D1: uhum

S1: eu não acho uma cidade ruim... com o tempo assim [hes.] é porque eu também não conhecia outra coisa né? [risos - D1] então por isso/ mas hoje em dia eu não conseguiria morar aqui pelo menos não agora

D1: uhum

S1: nessa etapa da minha vida... porque tanto por carreira profissional quanto acho que [hes.] eu [hes.] São Paulo é mais meu estilo de vida sabe? (M1B_gustavo)

Tabela 1: Migração itanhanduense ${ }^{11}$

Pessoas a partir de 5 anos de idade que não residiam em Itanhandu em 31/07/2005: 1.393 pessoas

\begin{tabular}{c|c|c|c}
\hline \multicolumn{2}{c|}{ Homens } & \multicolumn{2}{c}{ Mulheres } \\
\hline Área Urbana & Área Rural & Área Urbana & Área Rural \\
597 & 144 & 521 & 131 \\
\hline
\end{tabular}

O trânsito de pessoas para fora de Itanhandu é tão costumeiro que há na cidade uma festa anual conhecida como "Festa do itanhanduense ausente" (o nome oficial é "Encontro de itanhanduenses \& amigos"12). A intenção da festa é promover um encontro entre pessoas que deixaram a cidade, mas que voltam periodicamente a ela.

Ao se comparar a migração existente em Itanhandu com a que se verifica em Passa Quatro e Itamonte, duas cidades mineiras com as quais possui limite geográfico (Figura 5), vê-se que a quantidade de itanhanduenses morando fora $(9,8 \%$ da população total da cidade) é bem superior à quantidade de passaquatrenses (546 pessoas ou $5 \%$ ), praticamente o dobro, e

11 Dados retirados do Censo Demográfico de 2010. Acesso pelo site http:/ / www.cidades.ibge.gov.br/xtras /temas.php?lang=\&codmun=313310\&idtema $=9$ 7\&search=minas-gerais $\mid$ itanhandu | censo-demografico-2010:-resultados-da-amostramigracao--. Último acesso em 08 de Junho de 2015.

em:

http://www.itanhandu.mg.gov.br/portal/index.php?option=com_content\&view=catego $\underline{\text { ry\&layout }=\text { blog\&id=7\&Itemid=8 }}$. Último acesso em 08 de Junho de 2015. 
levemente maior do que a de itamontenses (1.349 pessoas ou $9,6 \%)^{13}$ que vivem fora de Itamonte. Os dados referentes às migrações nestes três municípios são apresentados na Figura 6 abaixo.

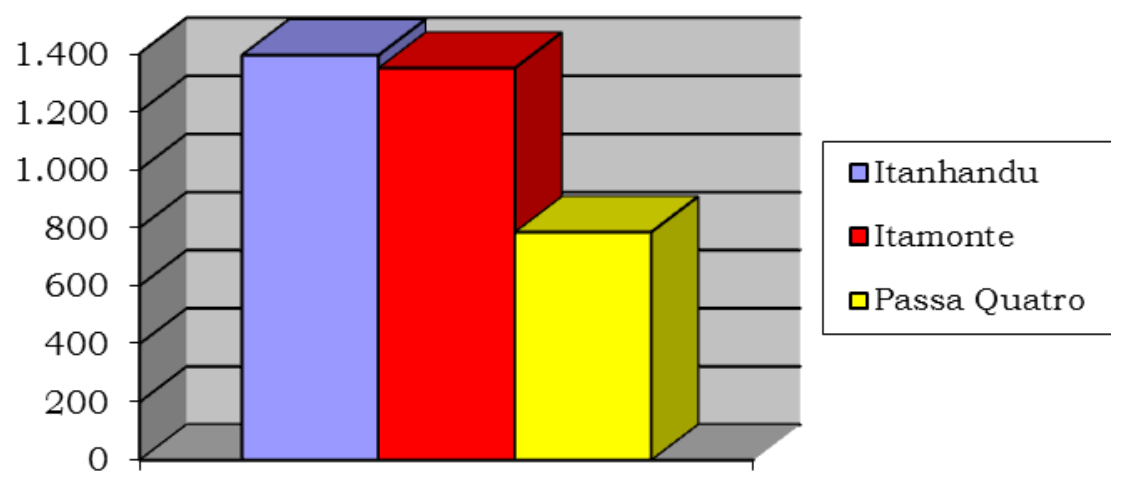

Figura 6: Número de migrações em Itanhandu, Itamonte e Passa Quatro

As trocas sociais, econômicas, culturais e mesmo linguísticas entre Itanhandu e o estado de São Paulo parece ser tão grande que a informante Lúcia chega a argumentar que a pequena cidade em que ela mora não é composta de "mineiros legitimos". Ela diz:

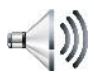

S1: o pessoal realmente eles vão para São Paulo

D1: para comprar roupa também né... o pessoal

S1: para comprar roupa... para ir na vinte e cinco [risos - D1] tudo se faz em São Paulo [risos - S1] é eu acho/

D1: por que as pessoas não vão tanto para Belo Horizonte? você acha/

$\mathrm{S} 1$ : pela distância

D1: pela distância?

S1: é bem/ eu que vou para Belo Horizonte sempre... é pela distância e aqui é uma coisa engraçada porque o mineiro de Itanhandu não é um mineiro legítimo não [risos - D1] porque aqui é uma/ você vai fazer uma pesquisa você vai perguntar time de futebol todo mundo torce ou para o botafogo corinthians [risos - D1] aqui não tem [barulho de ônibus] atleticano não tem cruzeirense... então quer dizer realmente parece que a capital deles é São Paulo...

D1: entendi

13 Dados obtidos do Censo Demográfico de 2010. Os dados referentes a Passa Quatro podem ser obtidos pelo link: http:/ / www.cidades.ibge.gov.br/xtras / temas.php?lang=\&codmun $=314760 \&$ idtema $=9$ 7\&search=minas-gerais $\mid$ passa-quatro $/$ censo-demografico-2010:-resultados-daamostra-migracao--. Último acesso em 08 de Junho de 2015.

Já os dados referentes a Itamonte podem ser acessados pelo link: http://www.cidades.ibge.gov.br/xtras/temas.php?lang $=\&$ codmun $=313300 \&$ idtema $=9$ 7\&search=minas-gerais $\mid$ itamonte $\mid$ censo-demografico-2010:-resultados-da-amostramigracao--. Último acesso em 08 de Junho de 2015. 
S1: que eles não tem refe/ eh Belo Horizonte como referência... é médico.. qualquer coisa mais grave que você tem eles vão/ eles recorrem para São Paulo... então aqui não é o mineiro de verdade sabe assim? (F3B_lúcia)

Somando-se a isso, alguns itanhanduenses argumentam que o modo como se fala na cidade parece ser resultado de uma mistura do falar mineiro com o carioca e o paulista/paulistano.

S1: não... eu acho que [hes.] em Belo Horizonte fala muito mais... cantado puxado... eu acho que aqui... por ser uma região entre São Paulo e Rio fica meio influenciado assim D1: uhum

$\mathrm{S} 1$ : pelos dois [hes.] pelas duas regiões e não tão influenciado pela ci/ pelo [hes.] por Belo Horizonte

D1: é porque fica bem longe da capital né?

S1: é... então o sotaque não é tão puxado (...) o pessoal de Passa Quatro... falava [ruído] [risos - S1] o pessoal de Passa Quatro falava que a gente falava puxado porque a gente era [hes.] Itanhandu capital do Rio sabe? eles falavam assim [risos - S1, D1] é porque a gente pux/falava muito puxado e eu não acho... sabe? assim eu não sei se são deles com a gente (F1B_cristina)

S1: Itanhandu mesmo não tem um sotaque né? o itanhanduense eu acho que ele é uma... uma mistura né? porque a gente não tem um [hes.]

D1: você acha que é mistura do que assim?...

S1: eu acho que é mais parecido com o paulista

D1: com o paulista?

S1: eu acho... sem o porta [imitação do erre tepe] o [hes.] né? (F2B_marcela)

Lúcia também tece comentários sobre a classificação de Itanhandu de acordo com um possivel "indice de mineiridade" por ela imaginado.

S1: aqui é uma cidade que... fria... que você não con/ que você não acha um restaurante com fogão a lenha [risos - D1] então quer dizer... aqui é uma região de truta... de queijos os melhores queijos né todos os tipos de queijos nós temos parmesão todos os tipos... aqui não tem um restaurante que serve os queijos da região [risos - D1] não tem um fogão a lenha para explorar...

D1: uhum

S1: a minei/ né

D1: a comida né

$\mathrm{S} 1$ : a comida mineira... não tem nada [sinos tocando] não tem a truta que a região forte de truta é Itamonte

D1: uhum

S1: quer dizer... é do lado dez quilômetros daqui... as pessoas também não sabe explorar... a [hes.] as trutas... e Itamonte e Passa Quatro eles exploram isso direitinho então eu acho [risos - D1] que Itanhandu falta administração falta gente para olhar esse lado... para melhorar o turismo

D1: mas você acha que... Itamonte e Passa Quatro é mais mineiro do que Itanhandu? 
S1: bem mais

D1: $e$

$\mathrm{S} 1$ : bem mais mineiro [risos - D1] bem mais mineiro e exploram mais esse lado (F3B_lúcia)

De acordo com Lúcia, as cidades imediatamente vizinhas a Itanhandu Itamonte e Passa Quatro - exploram seu potencial turístico. Nelas, há grandes hotéis, a prática de esportes radicais, passeio turístico em trem antigo e outras tantas atividades. Itanhandu, ao contrário das duas, tem sua economia voltada ao agronegócio (Figura 7 abaixo). A avicultura é bastante estimulada na cidade, com destaque para a produção de ovos (a maior granja da cidade chega a produzir 360.000 por dia) ${ }^{14}$.

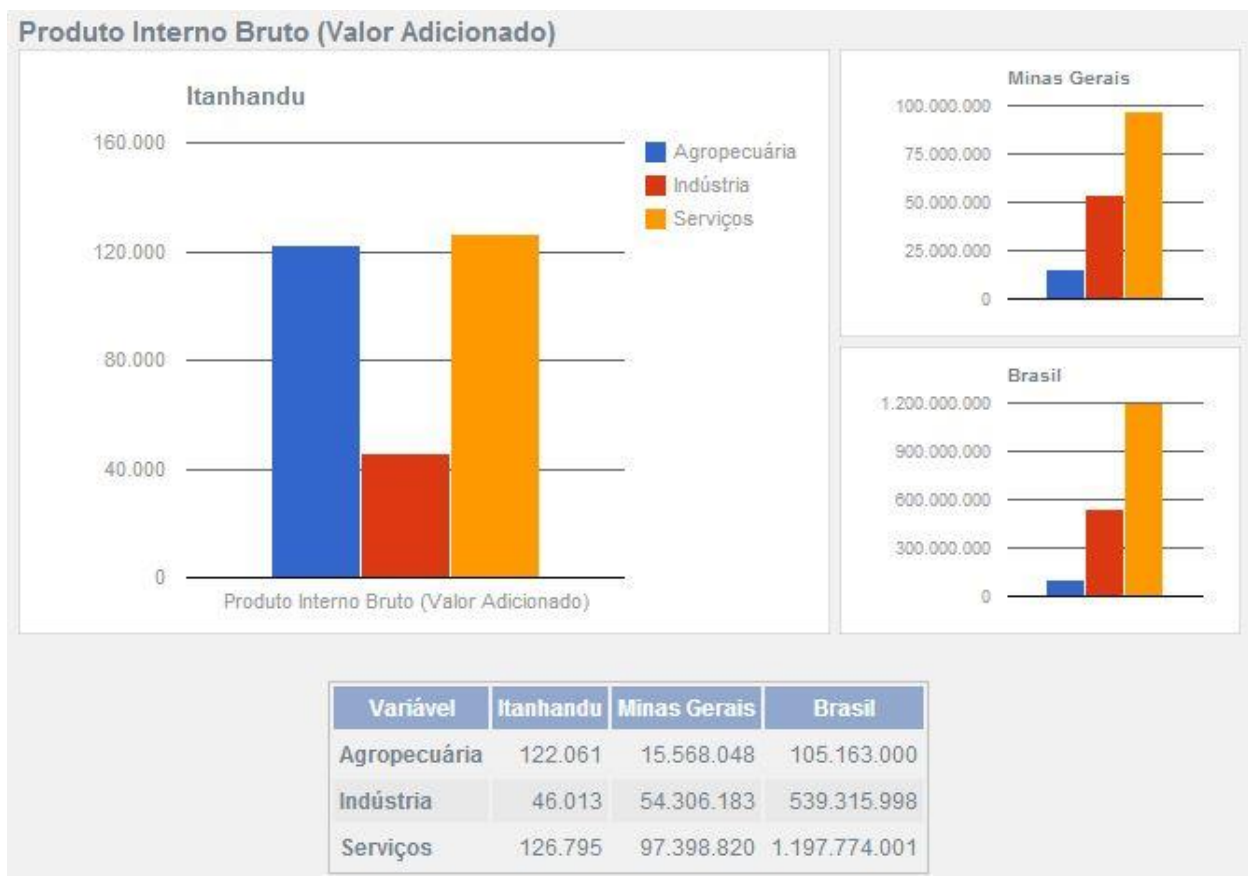

Figura 7: Dados da economia itanhanduense ${ }^{15}$

Se, por um lado, o que a informante acima aponta como "falta de mineiridade" pode ser entendido como opção econômica, por outro, existem numerosos dados para se investigar, de maneira mais detida, a identidade

\footnotetext{
14 http://www.granjasantamarta.com.br/home/. Último acesso em 08 de Junho de 2015.

15 Disponivel em:

$<$ http: / / cidades.ibge.gov.br/painel/economia.php?lang $=8$ codmun $=3133108$ search $=\mathrm{m}$ inas-gerais |itanhandu |infogr\% E1 ficos:-despesas-e-receitas-or\% E7ament\%E1rias-epib> Acesso em 08 de Junho de 2015.
} 
itanhanduense, algo que pode acarretar, como se verá mais adiante, consequências linguísticas.

2. O predomínio da pronúncia retroflexa de (-r) em Itanhandu

2.1. O (-r) em Itanhandu

Corroborando o que afirmam muitos autores (RIBEIRO et al., 1977, ZÁGARI, 1996, 2005; BRANDÃO, 2007, AGUILERA; SILVA, 2011) acerca da presença bastante marcante do retroflexo no Sul de Minas Gerais, a Tabela 2 abaixo ilustra a alta frequência dessa pronúncia em Itanhandu $(90,8 \%$ de 10.916 dados), extraídos das entrevistas com itanhanduenses.

Tabela 2: Distribuição geral das ocorrências de (-r) em Itanhandu 16

\begin{tabular}{ccc}
\hline Casos de (-r) & $\mathrm{N}^{\circ}$ & $\%$ \\
\hline Retroflexo & 9.913 & 90,8 \\
Fricativo & 917 & 8,4 \\
Tepe & 86 & 0,8 \\
\hline TOTAL & 10.916 & 100 \\
\hline
\end{tabular}

A primeira referência à realização da variante retroflexa - que também parece ser o passo primeiro no caminho da descrição acústica desse som - foi feita por Amadeu Amaral em O dialeto Caipira no início dos anos 20. Segundo Amaral (1976):

r inter e post-vocálico (arara, carta) possui um valor peculiar: é línguo-palatal e guturalizado. Na sua prolação, em vez de projetar a ponta contra a arcada dentária superior, movimento este que produz a modalidade portuguesa, a língua leva os bordos laterais mais ou menos até os pequenos molares da arcada superior e vira a extremidade para cima, sem tocá-la na abóbada palatal. Não há quase nenhuma vibração tremulante. Para o ouvido, este $r$ caipira assemelha-se bastante ao $r$ inglês post-vocálico. É, muito provavelmente, o mesmo $r$ brando dos autóctones. Estes não possuíam o rr forte ou vibrante, sendo de notar que com o modo de produção acima descrito é impossivel obter a vibração desse último fonema. (AMARAL, 1976: 47).

16 Por causa dos objetivos desse trabalho, os casos de apagamentos, apesar de bastante numerosos (6.733 ocorrências), não foram considerados nas análises. 


\subsection{Características acústicas do /-r/ retroflexo}

Segundo Maia (1985 apud FERRAZ, 2005, p.15), a articulação do /-r/ retroflexo no Português Brasileiro evidencia-se como mais recuada do que a articulação de um alveolar. Na produção do [.]. a língua flexiona-se para trás e sua superficie inferior se aproxima do céu da boca, o que, de certa forma, aproxima esse som de descrições já feitas para o retroflexo no inglês norteamericano (LADEFOGED; MADDIESON, 1996).

De modo geral, o /-r/ retroflexo é caracterizado por um abaixamento de F3, que passa a ter valores abaixo ou iguais a $2.000 \mathrm{~Hz}$ (LEHISTE, 1962; LINDAU, 1985 apud FERRAZ, 2005, p. 23 e 26) e uma consequente aproximação deste em relação a F2.

Entretanto, Ferraz (2005) constatou, em seu estudo sobre a comunidade de fala de Pato Branco/PR, que o valor de F3 do /-r/ retroflexo é muito próximo do valor de F3 da aproximante alveolar, às vezes até mais alto. O autor também nota em seus dados a existência de médias bastante frequentes acima de $2.000 \mathrm{~Hz}$ para F3:

(...) são poucas as ocorrências de F3 do [.] abaixo de $2.000 \mathrm{~Hz}$ para os contextos vocálicos adjacentes anteriores; por outro lado, é rara a incidência do F3 do [r] acima de $2.000 \mathrm{~Hz}$ para os contextos vocálicos adjacentes posteriores. (FERRAZ, 2005: 91).

Todavia, o mesmo autor destaca "um acentuado abaixamento de F3 no contexto vocálico posterior" (FERRAZ, 2005, p. 82). Dessa forma, no PB, parece ser forte o efeito de co-produção das vogais sobre a realização do [.]. Segundo Ferraz (2005), "F2 e F3 se apresentam mais altos para as vogais anteriores e mais baixos para as posteriores (...)" (FERRAZ, 2005: 84).

No espectrograma a seguir, extraído de Ferraz (2005), é possivel visualizar o comportamento de F2 e F3 no /-r/ retroflexo que se realiza após a vogal média baixa / ว/. O segmento retroflexo está destacado em amarelo. 


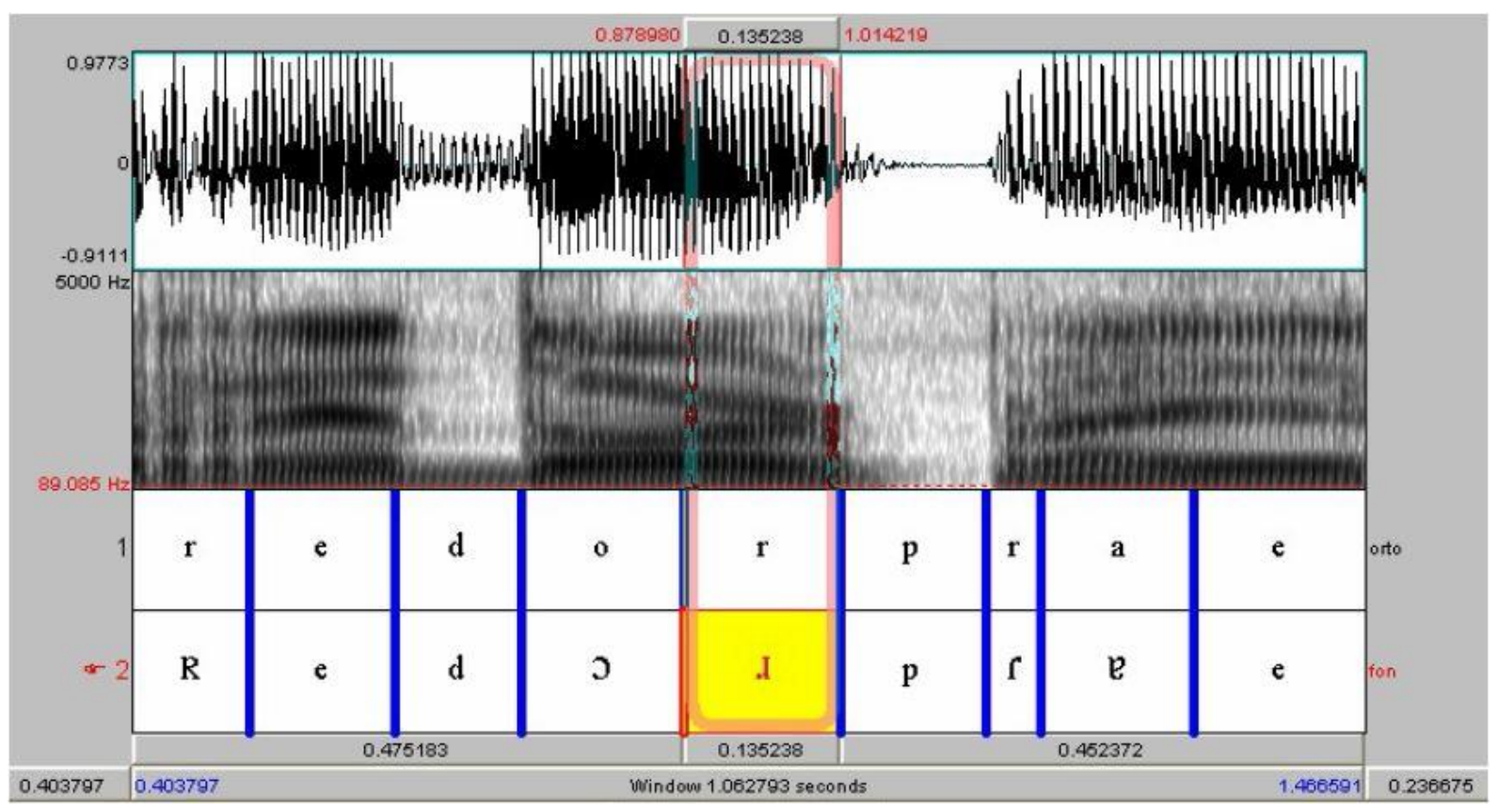

Figura 8: Forma da onda e espectrograma da sequência "redor pra e" na sentença “digo redor pra ele” (FERRAZ, 2005)

Segundo o mesmo autor, a posição que tal variante ocupa na palavra, medial ou final, não produz diferenças significativas na medição de F1, F2 e F3 da variante retroflexa. Ele afirma:

Podemos, por enquanto, apenas dizer que, acusticamente, as produções de [r] nas posições de coda silábica no meio e no final de palavra - para os vocábulos dissílabos paroxítonos e oxítonos - conforme os nossos dados apontaram, são semelhantes. (FERRAZ, 2005: 63).

Ferraz (2005) argumenta que, no PB, não há um abaixamento de F3, mas sim um efeito de bemolização (JAKOBSON; FANT; HALLE, 1976) do [.] em relação ao contexto vocálico adjacente, ou seja, há uma queda brusca do F3 do rótico em comparação com o F3 da vogal, mas isso não significa necessariamente que o F3 do retroflexo seja baixo. O autor utiliza o termo "bemolizado" em referência ao traço [bemolizado] sistematizado por Jakobson, Fant e Halle (1952) e que envolve em sua definição uma queda brusca do valor da frequência ou o enfraquecimento de alguns componentes.

Em Itanhandu, a análise dos dados, e sua consequente classificação em retroflexos, tepes e fricativos, foi feita de oitiva, uma vez que apenas parte dos dados recebeu uma análise acústica mais sistematizada com o auxílio do programa Praat (BOERSMA; WEENINK, 2015). 


\section{A existência de Graus de Retroflexão}

Conforme mostra a Tabela 2, tepes e fricativos totalizam 1.003 ocorrências em 10.916 dados de (-r) itanhanduenses, o que representa $9.2 \%$.

Além de ser um número considerável qualitativamente (OUSHIRO, 2015), já que se trata de uma comunidade do interior sul mineiro que, como já se viu, é caracterizada pela alta frequência de [.]. também é quantitativamente (GUY; ZILLES, 2007).

Dessa maneira, a primeira análise que será apresentada no Capítulo 5 abarcará os casos de (-r) realizados como retroflexos versus /-r/ não prototípicos em Itanhandu (fricativos e tepes).

Outro fato linguístico evidenciado em Itanhandu, à semelhança do que já foi constatado para outras comunidades de fala (LEITE, 2004, 2010, FERRAZ, 2005), é a existência de diferentes realizações da variante retroflexa. É possivel perceber a realização de, pelo menos, dois "graus de retroflexão": casos de (-r) mais duradouros e intensos (Figura 9); casos de (-r) mais curtos e "fracos" (Figura 10).

Nos espectrogramas abaixo, é possivel visualizar a diferença entre esses dois tipos de retroflexos. O primeiro espectrograma traz o (-r) na palavra "parte" e o segundo traz a mesma variável na palavra "curso" (palavras retiradas dos excertos 12 e 13 abaixo).

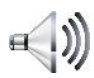

S1: ah... pode falar no contexto geral assim de escola?

D1: pode

S1: ah... eu vejo que hoje em dia mudou muito a parte de [hes.] estudo também (F1A_viviane)

D1: até que série você estudou?

S1: eu fiz o curso superior (F1A_viviane) 


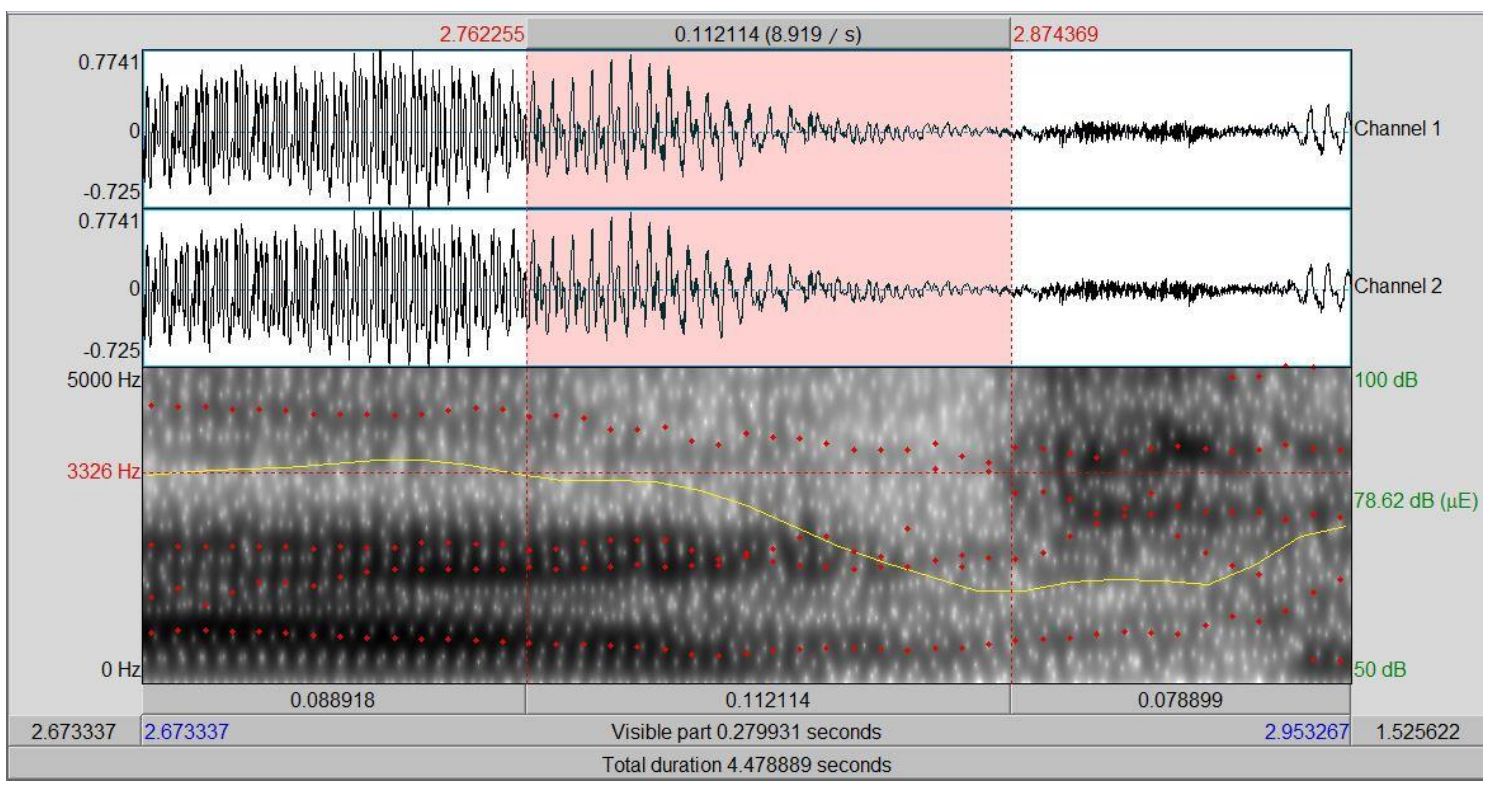

Figura 9: /-r/ considerado forte

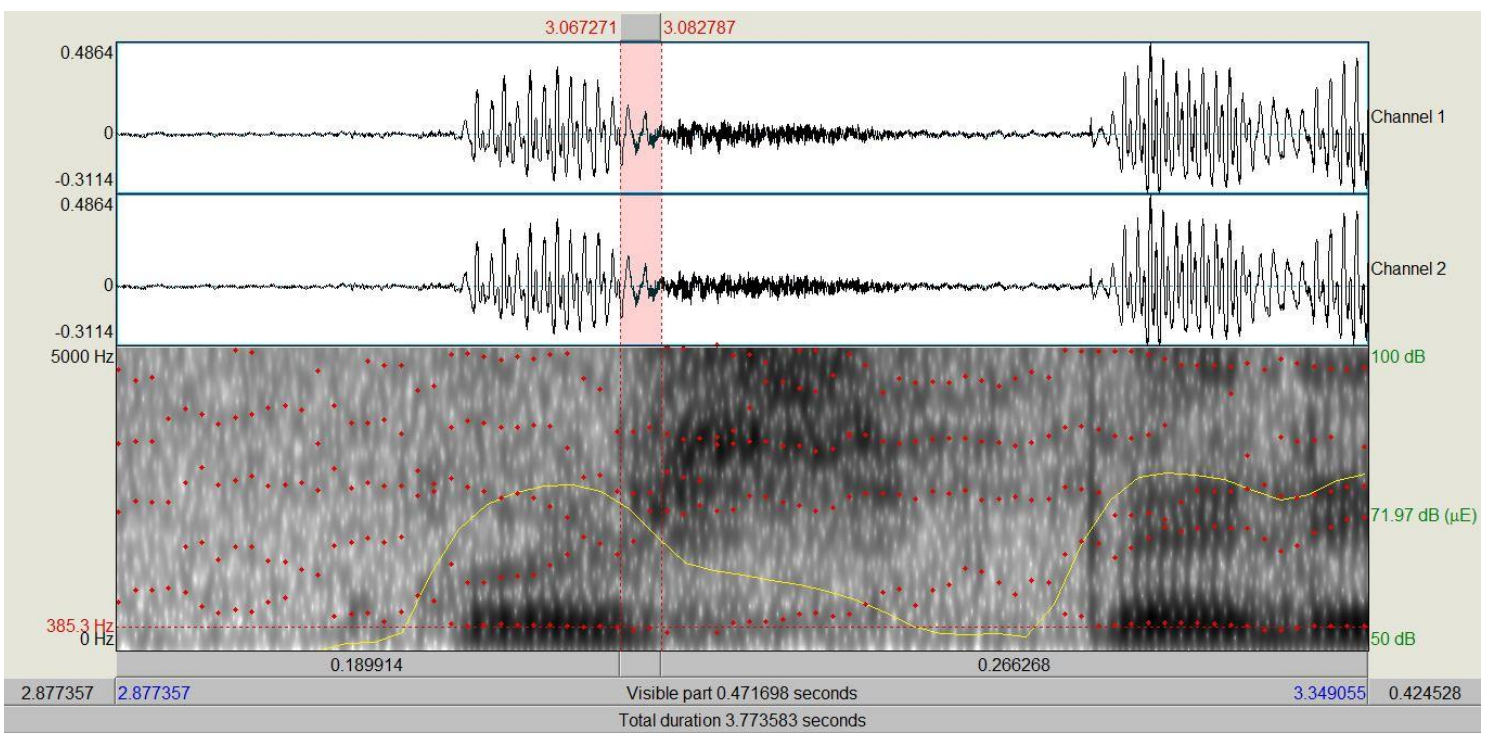

Figura 10: /-r / considerado fraco

Ao compararmos as realizações de $(-r)$ nas duas figuras acima, podemos perceber que se trata de duas realizações marcadamente distintas.

$\mathrm{Na}$ Figura 9, o /-r/ considerado tem uma duração de, aproximadamente, 0.112 segundo e uma alta intensidade, quando comparado ao /-r/ presente na Figura 10. A intensidade de um som é marcada pela linha amarela que aparece no espectrograma. Para o /-r/ considerado forte, observa-se que a intensidade é alta e, logo depois, sofre uma queda porque a consoante que virá depois é uma oclusiva. 
Já na Figura 10, a duração do /-r/ é de, aproximadamente, 0.472 segundo e a intensidade é comparativamente menor. O /-r/ fraco aparece após a vogal $u$ e é nítida a queda de intensidade que ocorre entre a vogal e o rótico, algo menos evidente quando se considera a transição entre a vogal $a$ e o /-r/ forte.

Os dois primeiros formantes dos mais diversos sons trazem informações acústicas importantes sobre eles e tais informações mostram-se intimamente ligadas aos movimentos articulatórios envolvidos na produção desses sons. F1 traz informações sobre o movimento de abertura e fechamento da mandíbula. Já F2 fornece informações sobre o movimento do principal articulador, a lingua.

Duração e intensidade foram os dois critérios utilizados na diferenciação dos dois graus de retroflexão observados em Itanhandu. Isso porque o fator frequência dos formantes, com destaque para o F3, que é o parâmetro que traz informações acústicas sobre os sons de erres realizados como retroflexos, não contribui muito para diferenciar os dois /-r/ retroflexos presentes nas Figuras 9 e 10 apresentadas acima.

A percepção da existência de graus de retroflexão também pareceu perceptível a alguns dos informantes que compõem a amostra. É claro que os itanhanduenses não dizem literalmente que "existem duas formas diferentes de realização do retroflexo na cidade", mas, quando afirmam que lá "não se puxa tanto o erre", eles querem dizer também há uma retroflexão "mais branda".

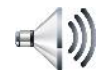

S1: jeca né? [risos] mó jecão/ não que tipo assim que nem quando eu fui as meninas falavam assim nossa você não parece de interior... porque num falava puxando tanto $o$ erre (F1B_heloísa)

Dessa forma, o Capítulo 5 também traz uma análise quantitativa dos dados da perspectiva de dois graus de retroflexão, pois os dados de /-r/ retroflexos contabilizam quase dez mil ocorrências, o que exige um olhar concentrado nelas.

Novamente, deve-se destacar que não se realizou uma análise acústica de todas as ocorrências. Os dados foram codificados de oitiva, a partir da análise acústica de algumas ocorrências. 


\section{Avaliações e percepções sociolinguísticas}

Ao fim das entrevistas sociolinguísticas, fizeram-se perguntas acerca das características do "falar itanhanduense", e sobre possiveis diferenciações notadas entre o falar da cidade em que nasceram e o "falar carioca e paulistano/paulista" (ver roteiro Anexo I).

Esse ponto das entrevistas tinha o objetivo de obter dos informantes avaliações e percepções sobre o modo como se fala em Itanhandu e verificar se manifestam, em relação a ele, algum tipo de avaliação em termos de prestígio ou desprestígio social dentro da comunidade.

A primeira pergunta foi sobre características que poderiam ser atribuídas ao falar itanhanduense. Vê-se, na figura abaixo, que o adjetivo mais frequentemente associado ao modo de falar itanhanduense é "mistura" (13 ocorrências), seguido, de longe, por "normal", citado 7 vezes.

Tal questão foi feita a trinta e quatro entrevistados. Àqueles que foi perguntada, somente um não soube responder.

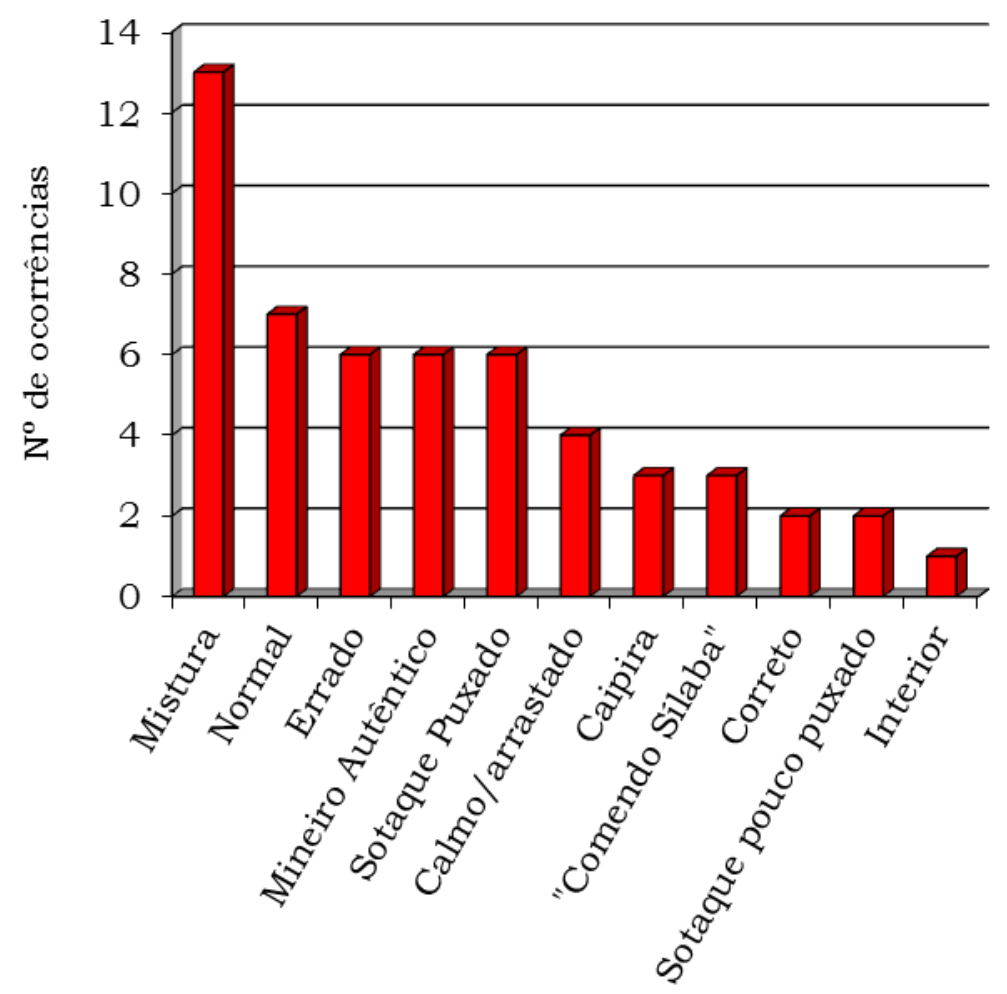

Figura 11: Adjetivos atribuídos ao "falar itanhanduense"

O gráfico acima indica que grande parte dos itanhanduenses vê seu "sotaque" como uma mistura, de modo geral, resultante da mescla entre os 
falares mineiro, carioca e paulista. Além disso, não há nenhuma característica fonético-fonológica (como a referência ao (-r)) que "salte aos olhos" dos itanhanduenses na classificação do modo como falam. Isso, de certa forma, está indicado indiretamente pelo adjetivo "normal", que é o segundo mais utilizado para caracterizar a fala da cidade.

A segunda pergunta feita aos itanhanduenses no sentido de investigar percepções e avaliações sobre o falar local realizou-se após a leitura da lista de palavras. Nela, os itanhanduenses deveriam indicar diferenças entre o falar itanhanduense e os falares carioca e paulistano. Na figura 12 abaixo, é possivel visualizar o que os itanhanduenses citaram como as principais diferenças entre o falar itanhanduense e o falar carioca. Na figura 13, é possivel ver as respostas referentes a diferenciações em relação ao falar paulistano.

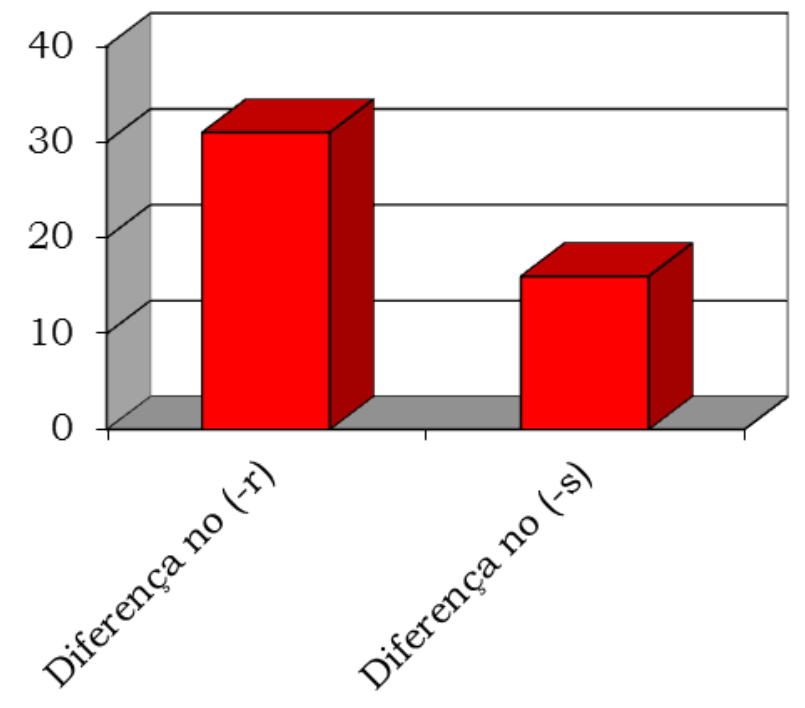

Figura 12: Diferenças entre o falar itanhanduense e o carioca

As principais diferenças residem na pronúncia do rótico e da sibilante quando em posição de coda silábica. Ou melhor, para os itanhanduenses, é bastante saliente a forma como os cariocas pronunciam o (-r) e o (-s). 


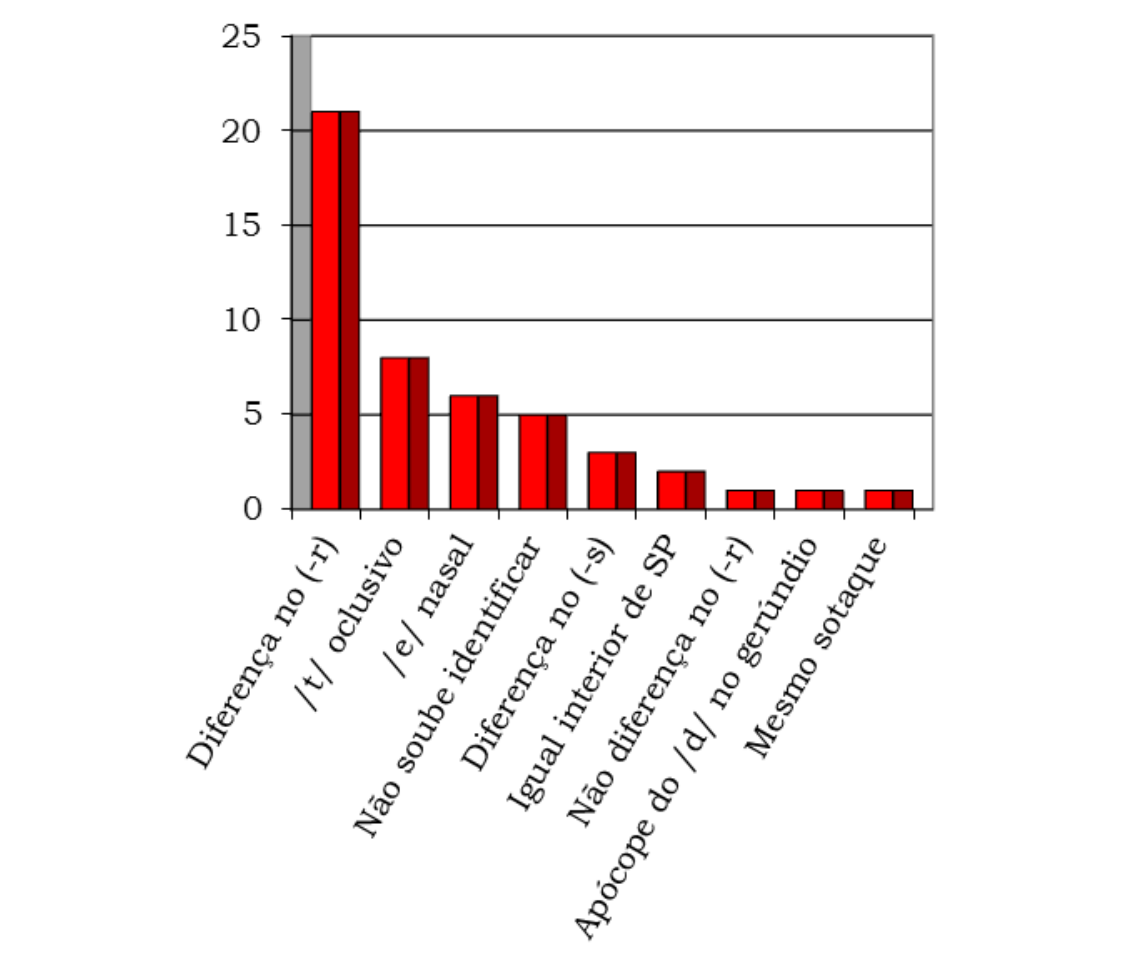

Figura 13: Diferenças entre o falar itanhanduense e o paulistano

Relativamente ao falar paulistano, os aspectos indicados como diferenciadores são da mais variada natureza. $O$ mais frequentemente apontado é a pronúncia distinta para o (-r), seguido de longe pela pronúncia oclusiva do (t-) em vocábulos como 'tia', 'dia', 'dente' etc.

Comparando a Figura 12 com a Figura 13, pode-se dizer que, para os itanhanduenses, é mais saliente a diferenciação do falar da cidade, no que diz respeito ao (-r), relativamente ao falar carioca do que ao paulistano. Talvez por isso, conforme pode ser visto na Tabela 2 (Cf. Item 2.1. O (-r) em Itanhandu), a taxa de realização da variante fricativa na cidade seja bastante superior a de (-r) realizados como tepe, ou melhor, quando os itanhanduenses buscam se indexicalizar como "urbanos" ou "metropolitanos", fazem-no mais por meio do emprego da variante utilizada na capital fluminense e menos com o uso daquela empregada na maior metrópole brasileira. Os capítulos a seguir discutem tal questão com maior profundidade.

Outra pergunta que se fez aos informantes, com a utilização de uma pronúncia retroflexa exagerada para os róticos destacados, foi: "O que você acha de 'ocê fica sem ter o que fazer'?" Essa pergunta objetivava verificar a saliência do uso dessa variável dentro da comunidade de fala itanhanduense. 
As respostas foram bastante reveladoras. Dos trinta e seis informantes entrevistados, somente seis notaram o uso exagerado do retroflexo e o avaliaram. Os demais entrevistados notaram apenas o uso do pronome 'você' com a apócope do v- e, no geral, o avaliaram negativamente, associando tal fenômeno às pessoas com baixa escolaridade ou moradoras de zona rural.

Quatro dos seis entrevistados que notaram o uso exagerado do (-r) retroflexo associaram-no ao sul de Minas e dois o avaliaram negativamente (como variante "feia"), mas afirmaram utilizá-lo quando não estão se monitorando. Um último informante afirmou ainda que o exagero no uso do (-r) retroflexo não é algo praticado pelos itanhanduenses, mas sim uma realidade existente "mais para o interior" do país.

A baixa frequência de avaliações sobre o (-r) retroflexo (30 dos 36 informantes não comentaram nada a respeito) pode ser interpretada de dois modos distintos, mas complementares. A sentença utilizada para obtenção de avaliações linguísticas continha dois fenômenos (apócope do v- de 'você' e uso exagerado do retroflexo) e um deles - o uso de 'ocê' - mostrou-se mais saliente, uma vez que recebeu atenção e avaliação negativa da maioria dos entrevistados. Por ter sido colocado junto a um fenômeno passível de avaliação social em Itanhandu, o (-r) retroflexo teria recebido menor atenção em consequência de sua relativamente menor saliência social para os itanhanduenses.

Complementarmente, pode-se vislumbrar que o uso exagerado do (-r) retroflexo não é passivel de avaliação social, ou seja, em princípio, o retroflexo não chama a atenção em Itanhandu (da mesma forma que o fricativo, por exemplo). Entretanto, parece que o retroflexo passa a receber avaliação social quando oposto ao uso de tepes e fricativos, frequentemente empregados em Itanhandu para marcar uma identidade "urbana" e "metropolitana" e, consequentemente, distante da realidade itanhanduense.

À semelhança do que propõe Oushiro (2015) em relação às variantes de (-r) encontradas na cidade de São Paulo, é possivel pensar na existência de uma forma default em Itanhandu, ou seja, uma variante não marcada, que seria o (-r) retroflexo, a partir da qual “(...) múltiplas outras variantes estabelecem 'outros' linguísticos” (OUSHIRO, 2015: 101).

O capítulo a seguir apresenta os pressupostos teóricos e a metodologia que embasam a pesquisa sociolinguística realizada em Itanhandu. 


\section{Capitulo 2: Pressupostos Teóricos e Metodologia}

\section{Arcabouço teórico}

Este trabalho se desenvolve de acordo com os pressupostos teóricometodológicos da Sociolinguística Variacionista (LABOV, 2006; 1972; 1994; 2001; 2010) e de trabalhos da chamada "terceira onda" da Sociolinguística (ECKERT, 2008, 2010, 2012; IRVINE, 2001; SILVERSTEIN, 2003; CAMPBELLKIBLER, 2007; 2008). Destaca-se que apenas alguns termos e conceitos da "terceira onda" são importantes para este trabalho e não todas as suas premissas. Em outras palavras, as análises quantitativas (Capítulo 5) são feitas de acordo com os pressupostos teórico-metodológicos da Sociolinguística Variacionista (LABOV, 2006; 1972; 1994; 2001; 2010), ao passo que a análise qualitativa de dados de percepção e de produção se vale de conceitos da "terceira onda", tais como "tomada de posição", "significado social" (CAMPBELL-KIBLER, 2007; ECKERT 2008, 2010); e "identidade" (CAMPBELLKIBLER, 2007; ECKERT 2008, 2010), que serão melhor definidos a seguir, quando se trata especificamente dessa onda da sociolinguística. Um último conceito a ser definido é o de "comunidade de fala", termo também bastante importante para este trabalho.

Segundo Eckert (2012), a primeira onda da sociolinguística se caracterizou pelo estudo das correlações entre variáveis linguísticas e categorias macrossociais, tais como classe social, sexo, etnia e idade. Essa primeira fase teve início nos anos 1960 e um dos trabalhos seminais foi Social Stratification of English in New York City (Labov, 1966 [2006]). Os estudos sociolinguísticos se multiplicaram a partir de então e inúmeros podem ser citados, não só para o inglês (WOLFRAM, 1969; TRUDGILL, 1974; MACAULAY, 1977 apud ECKERT, 2012, p. 88; LABOV, 1966), mas também para muitas outras línguas (CEDERGREN, 1973 apud ECKERT, 2012; MODARESSI, 1978 apud ECKERT, 2012; CALLOU, 1979; 1987; BRANDÃO, 2007).

De acordo com Eckert (2012): 
Esses estudos estabeleceram um padrão regular de estratificação socioeconômica da forma linguística, com maior diferenciação regional e étnica na extremidade inferior da hierarquia socioeconômica bem como um maior uso de formas não padrão mais difundidas. Estas formas, estigmatizadas no "mercado linguístico" padrão (Bourdieu \& Boltanski 1975), diminuem em frequência quando se move para cima através da hierarquia de classes. (ECKERT, 2012: 88). (tradução nossa). ${ }^{17}$

Nos estudos sociolinguísticos típicos de primeira onda, os padrões de variação observados na fala do indivíduo são normalmente explicados em correlação ao seu auto monitoramento, que, por sua vez, depende da situação de entrevista (conversa, leitura de um texto, leitura de listas de palavras). A isso Labov chama "estilo".

Além disso, os trabalhos de primeira onda tendem a compreender o fenômeno linguístico da variação a partir de categorias macrossociológicas, ou seja, é comum que padrões de uso verificados apareçam correlacionados ao sexo/gênero do informante, sua classe social e sua faixa etária. Dessa forma, nas palavras de Eckert (2012), dentro dos trabalhos de primeira onda "os falantes emergem como símbolos humanos - conjunto de características demográficas" (tradução nossa). ${ }^{18}$

Já nos trabalhos considerados de segunda onda, utilizam-se métodos etnográficos na busca de uma aproximação entre variação linguística e uma dinâmica local específica. Sobre essa vertente metodológica, Eckert (2012) afirma:

Esses estudos procuraram categorias locais que pudessem lançar luz sobre a relevância de categorias macrossociológicas para a vida em contextos locais, desenhando uma relação direta entre as dinâmicas sociais que dão origem a essas categorias e o uso de variáveis linguísticas. (ECKERT, 2012: 90-91). (tradução nossa) ${ }^{19}$.

17 Texto original: These studies established a regular pattern of socioeconomic stratification of linguistic form, with greater regional and ethnic differentiation at the lower end of the socioeconomic hierarchy as well as greater use of more widespread nonstandard forms. These forms, stigmatized on the standard language market (Bourdieu; Boltanski 1975), decrease in frequency as one moves upward through the class hierarchy. (ECKERT, 2012: 88).

18 Texto original: In this way, speakers emerged as human tokens-bundles of demographi characteristics.

19 Texto original: These studies sought out local categories that could shed light on the relevance of macrosociological categories for life in the local setting, drawing a direct relation between the social dynamics giving rise to these categories and the use of linguistic variables. (ECKERT, 2012: 90-91). 
Esta corrente metodológica é iniciada nos estudos variacionistas por Milroy (1980), que realiza uma pesquisa sobre variação fonológica dentro de redes sociais ${ }^{20}$ em Belfast. O estudo evidenciou uma forte correlação entre a produção de variantes locais e o engajamento do informante em redes sociais definidas étnica e localmente. Este estudo constatou ainda que uma forma vernacular (LABOV, 1972b), embora passivel de ser estigmatizada globalmente, pode ser associada a práticas locais e, então, receber localmente uma valoração positiva.

Considere-se, para dar um exemplo no cenário brasileiro, a concordância de $1^{a}$ pessoa do plural no PB. Vários estudos (SCHERRE; NARO; CARDOSO, 2007; OUSHIRO, 2015) têm mostrado que a não realização de concordância é estigmatizada em $\mathrm{PB}$, ou seja, produzir formas como "nóis vai" ou "eles faz" significa distanciar-se do "padrão culto". Entretanto, Coelho (2006), ao analisar 24 entrevistas sociolinguísticas de migrantes ou filhos de migrantes residentes no Jardim Paulistano (sub-distrito do bairro Brasilândia), região periférica e de origem favelada na cidade de São Paulo, observou que a ausência de concordância na primeira pessoa do plural (como na expressão "nóis é") é uma característica de toda a comunidade, marcando o pertencimento de seus membros a ela. Assim, vê-se que a variável linguística passa a ser ressignificada localmente e torna-se bem avaliada.

Diferentemente dos estudos de primeira e segunda ondas, que deram destaque a categorias aparentemente estáticas de falantes e entendem, no geral, identidade como afiliação a determinada categoria social (classe, idade, etnia), os estudos de terceira onda trouxeram uma visão de variação como um reflexo de categorias e identidades sociais construídas na prática linguística, em que falantes localizam-se no panorama social estilisticamente (ECKERT, 2012: 94).

Aqui, a noção de identidade torna-se fluida (IRVINE, 2001), à medida que, considera-se, pode ser "manipulada" pelo informante de acordo com suas intenções comunicativas e com os significados sociais de determinada variante que se deseja destacar.

Nas palavras de Eckert (2012):

20 Tradução para o termo "social networks" (BATTISTI, 2014). 
A variação constitui um sistema semiótico social capaz de expressar a total variedade das preocupações sociais de uma comunidade. Como as preocupações são mutáveis, as variáveis igualmente não podem ter significado fixo. Ao contrário, a propriedade central das variáveis é a mutabilidade indexical. Essa mutabilidade é alcançada na prática estilística, conforme os falantes marcam movimentos semióticos e sociais, reinterpretando as variáveis e combinando-as em um processo contínuo de bricolagem. (HEBDIGE, 1984 apud ECKERT, 2012: 94). (tradução nossa). ${ }^{21}$

Entretanto, é necessário relativizar o grau de agentividade com que o falante atua, pois, se por um lado não se deve entender o indivíduo como um simples produto das categorias macrossociais às quais se afilia, por outro não se pode atribuir a ele um papel tão decisivo na construção de sua própria fala e identidade. Segundo Oushiro (2015):

\begin{abstract}
Além da improbabilidade de que um indivíduo possa monitorar e manipular conscientemente cada traço linguístico de sua fala a todos os momentos, uma série de construtos sociais que servem de parâmetros identitários pré-existe e ultrapassa o domínio da ação individual. (OUSHIRO, 2015: 25).
\end{abstract}

A discussão que se fará no Capítulo 6 sobre a atuação dos grupos de fatores Identificação com a Cidade e Tempo Fora de Itanhandu sobre a variável independente (-r) ilustra a questão acima acerca do grau de agentividade do informante sobre sua própria fala.

Nos estudos de terceira onda, estilo não se define como atenção dada à própria fala por um falante (LABOV, 1972b; ECKERT, 2012:88); não se trata de uma manifestação superficial, mas sim que se origina no conteúdo. Diferentes maneiras de dizer a mesma coisa estão correlacionadas a diferentes "maneiras de ser". O significado social e a ideologia passam, então, a ser o centro da prática estilística. Cada movimento estilístico é resultado de uma interpretação do mundo social e do significado dos elementos dentro dele, bem como um posicionamento do falante em relação a esse mundo.

Neste sentido, imagine-se uma pessoa que sai do interior de São Paulo e migra para a cidade do Rio de Janeiro. Na capital fluminense, "seu" /-r/ é logo

21 Texto original: Variation constitutes a social semiotic system capable of expressing the full range of a community's social concerns. And as these concerns continually change, variables cannot be consensual markers of fixed meanings; on the contrary, their central property must be indexical mutability. This mutability is achieved in stylistic practice, as speakers make social-semiotic moves, reinterpreting variables and combining and recombining them in a continual process of bricolage (Hebdige 1984 apud ECKERT, 2012: 94). 
percebido como diferente do padrão da cidade e pode se tornar alvo de piadas. Enfrentando as piadas e numa tentativa de assumir uma identidade "caipira", o indivíduo pode não deixar de realizar "seu erre" como retroflexo. Assim, marca sua diferença em relação aos demais e assume uma postura ideológica de valorização de sua origem, através da produção de uma forma linguística frequentemente associada ao interior do país, com destaque para o interior de São Paulo. Com o tempo, pode ser que a frequência do retroflexo na fala desse indivíduo diminua (assim como a frequência de fricativas pode aumentar), mas o retroflexo pode continuar funcionando como marca de identidade.

Sendo a identidade algo fluido, os significados com que as variáveis linguísticas são empregadas na fala não são precisos ou fixos, mas constituem um campo de significados potenciais - o campo indexical (ECKERT, 2008; SILVERSTEIN, 2003) -, que é um conjunto de significados ideologicamente relacionados, sendo que qualquer um deles pode ser ativado por um certo falante numa certa situação de fala. Assim, cada variável linguística tem seu próprio campo indexical. Dessa maneira, o campo indexical é igualmente fluido, pois qualquer ativação de significados pode mudá-lo através de novas conexões ideológicas, que abrirão espaço a novos significados sociais atribuíveis àquela variável considerada.

Diferentemente do que se vê nas duas primeiras ondas dos estudos sociolinguísticos, nos estudos de terceira onda, as variáveis não são associadas a categorias sociais em si, mas sim a características que constituem essas categorias e a "tomadas de posição"22 (CAMPBELL-KIBLER, 2007; ECKERT 2008, 2010).

Se alguém se utiliza de uma variante específica de uma cidade ou região, por exemplo, ela não necessariamente se identifica com tudo o que diz respeito a esse lugar, mas com apenas alguma (ou algumas) característica(s) que o próprio falante atribui ao local.

Este parece ser o caso do fenômeno linguístico observado em Itanhandu. A produção das formas não prototípicas de (-r) na cidade (tepes e fricativos) parece indicar que (alguns) itanhanduenses identificam-se com certas características de São Paulo e do Rio de Janeiro (por exemplo, urbanidade, desenvolvimento, oportunidade de emprego) atribuídas por eles mesmos a essas cidades. Ou seja, os itanhanduenses podem identificar-se não

22 Tradução nossa para o termo "stances", ainda pouco utilizado na sociolinguística brasileira. 
com a realidade factual de São Paulo e Rio de Janeiro, mas sim com o que eles imaginam ser a realidade desses locais.

De acordo com Kiesling (2009), entende-se o conceito de "tomada de posição" (KIESLING, 2009) como uma identidade que o falante assume para si diante de seu interlocutor durante determinada situação comunicativa. Assim, "Tomada de Posição" (Stance) é uma atitude realizada pelo informante no "aqui e agora" da situação interacional (KIESLING, 2009). Isso significa que é uma atitude de momento e que, por isso, pode não corresponder à realidade do informante em sua vida cotidiana. Como exemplo, pode-se pensar em uma mulher que assume o papel de "mãe" frente a um filho, um papel de "esposa" diante do marido ou mesmo o papel de "empregada" frente a um chefe. Essas diferentes tomadas de posição podem influenciar a seleção linguística que tal mulher faz durante sua fala. Dessa maneira, as "tomadas de posição" estão relacionadas não só com o conteúdo da fala, mas também com a sociabilidade dela, ou seja, há uma preocupação com o que se diz e também com a maneira como isso será interpretado pelo interlocutor.

Para um estudo linguístico que se pretenda fazer em Itanhandu, comunidade de fala complexa do ponto de vista linguístico e identitário (no sentido da descrição feita no Capítulo 1), é necessário discutir alguns conceitos, como "identidade", "significado social", "lugar", "acomodação linguística" e "comunidade de fala". Tal atitude se faz imperativa, visto que as ocorrências de tepes e fricativos na fala local parecem não se dar apenas em decorrência da posição geográfica da cidade, mas também em razão de diferentes identidades (MENDOZA-DENTON, 2002) expressas em relação a diferentes "lugares" (JOHNSTONE, 2004).

Mendoza-Denton (2002) define identidade como uma negociação ativa de um indivíduo com construtos sociais maiores. Essa negociação pode se evidenciar através de formas linguísticas ou outros significados semióticos. Consequentemente, "identidade" não é nem um atributo, nem uma possessão, mas sim um processo de semiose, tanto no nível individual quanto no nível coletivo. A autora também destaca a importância de fatores socio-históricos e ideológicos na construção e na atribuição de identidades. O presente trabalho se coaduna com tal conceito de identidade.

Já Johnstone (2004) argumenta que há dois modos distintos de compreender o conceito de "lugar". Referindo-se à sua acepção mais comum na maioria dos estudos de cunho dialetológico e variacionista, a autora afirma 
que o termo "lugar" tem sido empregado em termos fisicos e objetivos. Dessa maneira, assume-se ser possivel identificar algo ou alguém a partir da localização espacial ocupada por eles ou mesmo a partir do lugar (físico ou espacial) do qual são originários. Dentro desta concepção, "lugar" é entendido como "a localização relativa de objetos no mundo" (ENTRIKIN, 1991: 10 apud JOHNSTONE, 2004: 66).

\begin{abstract}
Lugar nesse sentido (...) é fisico, identificável por uma série de coordenadas em um mapa; um lugar é diferente de outro porque tem localização diferente e possui características físicas diferentes. Lugares, nesse sentido da palavra, podem ser vistos objetivamente, através de um mapa ou pela janela de um avião, por exemplo. Lugares se relacionam à atividade humana em virtude de ser o contexto fisico e natural dela; lugar pode afetar a vida humana através de suas características físicas, por exemplo, possibilitando um certo tipo de agricultura ou provendo outros recursos naturais ou formas de transporte. (JOHNSTONE, 2004: 66). (tradução nossa). ${ }^{23}$
\end{abstract}

Os discursos sobre "lugar", quando este termo é entendido como localização física, são expositivos, já que eles existem independentemente de interpretações pessoais, pois os "lugares" podem ser objetivamente descritos e explicados. Assim, os "lugares" podem ser considerados como "valor neutro", ou seja, uma pessoa está em um lugar se ela está fisicamente localizada nele ou é de algum lugar se nasceu lá.

No começo dos anos 1970, surge um ramo da geografia, a "geografia humanística", disposta a conceber "lugar" de uma maneira diferente. Eles consideram "espaço" e "lugar" como dois conceitos socialmente construídos. Dentro dessa segunda concepção, a experiência humana é vista como fundamentalmente "localizada", pois há um interesse em entender a diferença entre "estar em um lugar" e "habitar um lugar" e nos significados e usos de ideias sobre região. Assim, "lugar" somente pode ser concebido como construção social.

${ }^{23}$ Texto original: Place in this sense, (...) is physical, identificable by a set of coordinates on a map; one place is diferente from another place because it is in a diferente location and has diferente physical characteristics. Places, in this sense of the word, can be seen objectively, on a map or out of an airplane window, for example. Places relates to human activity by virtue of being the natural, physical setting for it; place might affect human life via its physical characteristics, for example, by enabling a certain kind of agriculture or providing other natural resources or transportation arteries. (JOHNSTONE, 2004: 66). 
Nelson Rossi (1984: 106) afirma que "os lugares, as áreas, não existem nas ciências humanas como espaços físicos em si, mas como espaços sociais".

Segundo Yi-Fu Tuan (1974, apud JOHNSTONE, 2004:68), "lugar não é somente um fato a ser explicado no amplo campo do espaço, mas é também uma realidade a ser elucidada e entendida a partir da perspectiva das pessoas que dão significado a ele". ${ }^{24}$ Nesta segunda perspectiva, o conceito incorpora aspectos materiais, mas também experimentais (TUAN, 1974; ENTRIKIN, 1991 apud JOHNSTONE, 2004:68).

(...) um espaço se torna um lugar através da interação humana com ele, seja por meio da manipulação física, como agricultura, arquitetura e paisagismo, seja simbolicamente, através de lembranças, "formulações" (Schegloff, 1972), representações e narrações. (JOHNSTONE, 2004: 68). (tradução nossa). ${ }^{25}$

Johnstone (2004) toma esta segunda concepção de "lugar" como algo de grande importância para os estudos sociolinguísticos atuais. Os falantes são vistos como construtores do "lugar" por meio de suas experiências físicas e sociais com ele. Diferentes falantes podem orientar o "lugar", linguisticamente, de diferentes modos e com diferentes propósitos (JOHNSTONE, 2004: 66). Esta é a concepção de "lugar" que se adota neste trabalho para o entendimento da "identidade itanhanduense".

Outro conceito a ser definido é o de "acomodação linguística". Giles (1973) propõe que um indivíduo pode induzir outro a avaliá-lo mais favoravelmente por meio da redução de dissimilaridades existentes entre eles, ou seja, para ser avaliado positivamente (seja no aspecto social, econômico ou linguístico), aquele que fala busca aproximar-se daquele com quem fala. Para a autora, o processo de acomodação linguística opera dentro desse princípio e, como tal, pode ser um reflexo de um desejo pessoal por aprovação social. Tal

${ }^{24}$ Texto original: "place is not only a fact to be explained in the broader frame of space, but it is not only a fact to be explained in the broader frame of space, but it is also a reality to be clarified and understood from the perspectives of the people who have given it meaning".

25 Texto original: (...) a space become a place through human's interaction with it, both through physical manipulation, via such activities as agriculture, architecture, and landscaping, and symbolically, via such activities as remembering, "formulating" (Schegloff, 1972), depicting, and narrating. (JOHNSTONE, 2004: 68). 
conceito será de extrema importância quando da interpretação dos resultados para o grupo de fatores Tempo Fora de Itanhandu (Capitulos 5 e 6).

O último conceito a ser definido é o de comunidade de fala. Entende-se comunidade de fala à maneira laboviana (LABOV, 2008 [1972]), ou seja, conjunto de indivíduos que compartilham normas e usos linguísticos. A respeito da definição laboviana para tal conceito, afirma Oushiro (2015):

De acordo com sua teorização, os critérios para a delimitação de uma comunidade de fala são o compartilhamento de normas (ainda que inconscientes, pois não se limitam à avaliação do indivíduo) e a uniformidade linguística. É importante notar que essa "uniformidade" não é sinônimo de uma suposta "homogeneidade"; ao contrário, o prospecto é a existência de heterogeneidade ordenada (Weinreich et al., 1968) através do emprego variável e sistemático de diferentes variantes linguísticas. O compartilhamento e a uniformidade são entendidos como definidores de um "padrão", concebido e descrito a partir de um paradigma quantitativo (ver seção 2.3), em que o papel de diferentes fatores pode ser testado e comparado. (OUSHIRO, 2015: 21).

Considerando tal definição e o que já foi dito sobre Itanhandu no Capítulo 1, dentro deste trabalho, a cidade investigada será entendida como uma única comunidade de fala.

Baseando-se nos conceitos acima expostos, essa pesquisa pretende estudar também, ainda que de modo preliminar, como se constrói a "identidade itanhanduense" (em termos sociolinguísticos), à luz das correlações entre localidade e variação nas produções linguísticas. Para tanto, serão analisadas as pronúncias de (-r) e os graus de retroflexão em Itanhandu, tanto quantitativa quanto qualitativamente, bem como as percepções, por parte dos itanhanduenses, acerca de tais pronúncias.

\section{Metodologia}

2.1. A construção da amostra 
A construção da amostra utilizada nessa dissertação de mestrado foi realizada de 2010 a 2013. Como trabalho de Iniciação Científica ${ }^{26}$, entre 2010 e 2012, foram gravadas e transcritas 18 entrevistas sociolinguísticas em Itanhandu, com informantes estratificados de acordo com sexo/gênero, faixa etária (entre 18 e 30 anos, 31 a 45 anos, 46 a 65 anos) e identificação com a cidade (falantes que se identificam "totalmente" com a cidade e dizem não pretender mudar para outros lugares; falantes que não se identificam com Itanhandu e que prefeririam "morar fora" ou que, já morando "fora", tiveram que voltar à sua cidade natal; e, finalmente, falantes que saíram de Itanhandu e não pretendem retornar).

\begin{tabular}{c|c|c}
\hline Sexo/gênero & Faixa Etária & Graus de identificação \\
\hline M: Masculino & $1: 18$ a 30 anos & $\begin{array}{c}\text { I: mora em Itanhandu } \\
\text { e não quer sair } \\
\text { S: mora em Itanhandu e } \\
\text { quer sair ou teve que } \\
\text { voltar }\end{array}$ \\
F: Feminino & 2: 31 a 45 anos & $\begin{array}{c}\text { N: mora fora de Itanhandu } \\
\text { e não quer voltar }\end{array}$ \\
\hline
\end{tabular}

Quadro 1: Variáveis estratificadoras das entrevistas coletadas entre 2010-2012

Em 2013, a fim de ampliar tal amostra, coletaram-se mais 18 entrevistas sociolinguísticas na cidade sul-mineira, a partir dos mesmos critérios sociais. Entretanto, o grupo de fatores Identificação com a Cidade foi alterado, criando-se apenas dois grupos opostos entre si: itanhanduenses que não revelam desejo de deixar a cidade ou que almejam retornar a ela; itanhanduenses que desejam sair da cidade ou que não desejam retornar a ela.

Ao longo do Capítulo 1, introduziu-se uma discussão acerca da existência de, pelo menos, dois graus de identificação dos itanhanduenses com a cidade da qual são originários. Uma segunda discussão mais aprofundada acerca desse grupo de fatores e da motivação de sua escolha na análise dos dados itanhanduenses se desenvolve no item 1.1. do Capítulo 4, quando se trata dos grupos de fatores que estratificaram a amostra.

A alteração dos fatores iniciais que compunham tal grupo de fatores foi realizada porque o conjunto inicialmente nomeado "N" (Quadro 1),

26 A pesquisa foi, inicialmente, financiada pela CAPES e, em seu segundo ano de realização, pela Pró-Reitoria de Pesquisa da USP. 
itanhanduenses que moram fora e não desejam retornar à cidade, revelou comportamento social e linguístico muito próximo ao do conjunto nomeado "S". Na verdade, a reorganização feita no grupo de fatores Identificação com a Cidade apenas uniu os conjuntos inicialmente chamados de "N" e "S".

A variável Faixa Etária também precisou ser alterada. Em vez de se estabelecer o limite de 65 anos para a terceira faixa etária, ela passou a ser composta por informantes com 46 anos ou mais. Esse alargamento proposto para a terceira faixa tinha como objetivo aumentar a quantidade de possíveis informantes para a amostra, já que, em Itanhandu, cidade bastante atrativa para as pessoas da $3^{a}$ faixa etária, ou seja, para pessoas que já "ganharam" a vida e que agora almejam viver sossegadas em uma cidade pequena, mostrouse dificil encontrar informantes mais velhos que se classificassem entre aqueles que desejavam sair da cidade ou não tinham o desejo de retornar a ela.

O quadro a seguir resume, então, como se organiza a amostra da fala itanhanduense.

\begin{tabular}{|c|c|c|}
\hline Sexo/gênero & Faixa Etária & Graus de identificação \\
\hline \multirow{4}{*}{$\begin{array}{l}\text { M: Masculino } \\
\text { F: Feminino }\end{array}$} & & A: mora em Itanhandu \\
\hline & 1: 18 a 30 anos & e não quer sair ou mora \\
\hline & 2: 31 a 45 anos & B: mora em Itanhandu e \\
\hline & & quer sair ou mora fora e \\
\hline
\end{tabular}

Quadro 2: Variáveis estratificadoras da amostra itanhanduense

Combinados, esses fatores geram 12 perfis sociolinguísticos, para cada um dos quais foram gravados três informantes. Dentro dos estudos sociolinguísticos (LABOV, 2008 [1963]), conforme se discutirá no item 4 a seguir, busca-se a representatividade quantitativa. Dessa maneira, postula-se que cada perfil sociolinguístico deve ser representado no mínimo por três informantes, de modo que o total de entrevistas coletadas deva ser três vezes maior do que a quantidade de perfis sociolinguísticos obtidos a partir da multiplicação dos fatores que formam as variáveis independentes estratificadoras da amostra. Esse postulado tem como objetivo diminuir a possibilidade de que, trabalhando-se com apenas um ou dois informantes por perfil, esteja-se diante de individuos idiossincráticos, ou seja, alguém que, mesmo imerso dentro da comunidade de fala investigada, não a represente. 
Anteriormente à entrevista, perguntou-se aos informantes em qual grupo identitário se posicionariam, ou seja, com qual se identificavam. Afinal, esse foi um dos critérios utilizados na escolha dos informantes que comporiam a amostra e, por isso, era algo que precisava ser conhecido antes que a entrevista fosse realizada.

Alguns poucos informantes (dois ou três) hesitaram na categorização de si mesmos como membros de um ou de outro grupo de identificação, o que reflete a ideia de Mendoza-Denton (2002) a respeito do caráter instável da identidade. Apesar disso, eles conseguiram optar pelo grupo de identificação que mais se aproximava de suas escolhas em relação à cidade de Itanhandu.

\subsection{As entrevistas e os informantes}

A estratégia de amostragem utilizada para a coleta dos dados foi mista: não só houve contato com o contexto cultural e o arranjo social da comunidade de fala (a amostra foi coletada "in situ"), mas também utilizou-se o método conhecido como "redes sociais" (MILROY, 1980), ou seja, informantes foram contatados através de "amigos de amigos".

Tratando-se de uma comunidade de fala interiorana com aproximadamente $14 \mathrm{mil}$ habitantes, tornou-se praticamente inviável encontrar informantes que não conhecessem uns aos outros (o que garantiria, de certa forma, maior "independência linguística" entre os entrevistados). Além disso, o contato com os possiveis informantes mostrou-se facilitado quando uma pessoa já entrevistada indicava outra para uma possivel entrevista.

Assim, apesar do esforço em construir uma amostra minimamente aleatória, em alguns momentos, a rede de informantes ligou-se por relações fraternas e paternas. Entretanto, tal fato não diminui a representatividade nem a validade da amostra coletada, pois foram entrevistados informantes de bairros diferentes da cidade, com formações educacionais e sociais bastante distintas e, o mais importante, com produções e percepções linguísticas variadas.

As entrevistas foram gravadas, geralmente, nas residências dos informantes, objetivando minimizar o paradoxo do observador (LABOV, 1994; 2006), ou seja, a fim de que o informante produzisse sua fala o mais espontaneamente possível, como se não estivesse sendo observado por aquele que o está gravando. 
Alguns poucos informantes sentiram-se desconfortáveis com a situação de entrevista, principalmente quando lhes foi solicitado que lessem pequenos trechos escritos. Dois informantes precisaram ser auxiliados pela documentadora nesses momentos. Eles tiveram dificuldade nos trechos de leitura por terem passado por uma escolarização falha e terem tido pouco contato com o mundo da escrita.

Inseguro, um dos informantes pediu pra ver o roteiro da entrevista antes que ela começasse. Ele mostrou-se bastante amedrontado com o fato de ter que falar sobre Itanhandu. Disse que não sabia se conseguiria responder a tudo que lhe seria perguntado. Isso não parece ser comum na coleta de entrevistas sociolinguísticas, ou melhor, o informante não possui contato prévio com o conteúdo acerca do qual deverá discorrer, pois o roteiro de perguntas é apenas um apoio para o documentador e não algo que deva ser lido pelo informante. Esses cuidados são tomados para que a entrevista transcorra, tanto quanto possível, como um diálogo espontâneo.

Entretanto, no caso de Antônio, a concessão foi feita no momento em que se percebeu que a realização da entrevista estava ameaçada. Apesar do impasse, a entrevista com tal informante transcorreu sem problemas. Depois de iniciada a conversa, ela se deu o mais naturalmente possível até o fim da gravação.

O roteiro (Anexo I) preparado para as entrevistas trazia perguntas relacionadas à cidade, à infância do informante, à sua família, ao seu trabalho/ocupação e ao seu lazer. Trazia ainda, conforme visto (Capítulo 1), um conjunto de perguntas que objetivavam levar o informante a dar opiniões sobre algumas produções linguísticas, ou seja, a emitir algumas avaliações sociolinguísticas.

A concepção de tal roteiro segue estratégias adotadas pelo Grupo de Estudo e Pesquisas em Sociolinguística (GESOL) e que estão sistematizadas no Projeto SP 2010 (MENDES; OUSHIRO, 2013).

O roteiro previa também a leitura de uma lista de palavras, de uma notícia de jornal e de um depoimento (com características orais). A leitura desses textos visava a verificar uma possivel diferenciação nas produções linguísticas, comparativamente à conversação na entrevista. Isso se inspira em Labov (1966) e na sua definição de estilo, definido como grau de monitoramento que a pessoa faz de sua própria fala. 
Ao fim da entrevista, o documentador perguntava ainda a opinião do informante ("O que você acha de...") acerca de algumas sentenças que foram pronunciadas, propositalmente, com o uso exagerado de aspectos da fala mineira, como o (-r) fortemente acentuado como retroflexo, ou ainda com a redução do sufixo de diminutivo -nho em palavras como 'pouquinho' e 'potinho'.

Os informantes que compõem a amostra são, em sua maioria, itanhanduenses de nascimento. Aqueles que não nasceram na cidade (apenas 4 informantes, sendo que dois deles nasceram na cidade de Passa Quatro, cidade mineira vizinha de Itanhandu) passaram a viver lá ainda pequenos. O Quadro 3 organiza os informantes em seus perfis.

\begin{tabular}{|c|c|c|c|c|c|c|}
\hline Informante & $\begin{array}{c}\text { Grupo de } \\
\text { Identificação }\end{array}$ & $\begin{array}{l}\text { Sexo/ } \\
\text { Gênero }\end{array}$ & $\begin{array}{l}\text { Faixa } \\
\text { Etária }\end{array}$ & $\begin{array}{l}\text { Cidade Natal } \\
\text { (em MG) }\end{array}$ & $\begin{array}{c}\text { Parentes } \\
\text { Fora }\end{array}$ & $\begin{array}{l}\text { Anos } \\
\text { Fora }\end{array}$ \\
\hline Manoel & $\mathrm{A}$ & Masculino & $1^{\mathrm{a}}$ & Itanhandu & Não & 0 \\
\hline Daniel & A & Masculino & $1^{a}$ & Oliveira & Irmãos & 6 \\
\hline Rogério & $\mathrm{A}$ & Masculino & $1^{a}$ & Itanhandu & Não & 2,5 \\
\hline Mauro & $\mathrm{B}$ & Masculino & $1^{\mathrm{a}}$ & Itanhandu & Não & 1 \\
\hline Gustavo & B & Masculino & $1^{a}$ & Itanhandu & Irmã & 3 \\
\hline Ricardo & $\mathrm{B}$ & Masculino & $1^{\mathrm{a}}$ & Passa Quatro & Não & 6 \\
\hline Jorge & A & Masculino & $2^{a}$ & Itanhandu & Não & 0 \\
\hline Marcos & A & Masculino & $2^{a}$ & Itanhandu & Não & 0 \\
\hline Guilherme & A & Masculino & $2^{a}$ & Itanhandu & Não & 9 \\
\hline Humberto & $\mathrm{B}$ & Masculino & $2^{a}$ & Itanhandu & Irmãs & 12 \\
\hline Mário & B & Masculino & $2^{a}$ & Itanhandu & Não & 18 \\
\hline André & $\mathrm{B}$ & Masculino & $2^{a}$ & Itanhandu & Irmãs & 11 \\
\hline Antônio & $\mathrm{A}$ & Masculino & $3^{a}$ & Itanhandu & Irmã & 8 \\
\hline Josué & A & Masculino & $3^{a}$ & Itanhandu & Irmã & 0 \\
\hline Augusto & A & Masculino & $3^{a}$ & Itanhandu & Irmãos & 0 \\
\hline Leonardo & $\mathrm{B}$ & Masculino & $3^{\mathrm{a}}$ & Itanhandu & Irmãs & 41 \\
\hline Joaquim & B & Masculino & $3^{a}$ & Itanhandu & Irmãos & 23 \\
\hline Letícia & A & Feminino & $1^{\mathrm{a}}$ & Itanhandu & Não & 0 \\
\hline Raquel & A & Feminino & $1^{\mathrm{a}}$ & Itanhandu & Não & 0 \\
\hline Viviane & A & Feminino & $1^{\mathrm{a}}$ & Itanhandu & Irmão & 0 \\
\hline Miranda & B & Feminino & $1^{\mathrm{a}}$ & Itanhandu & Irmãos & 8,5 \\
\hline Cristina & $\mathrm{B}$ & Feminino & $1^{\mathrm{a}}$ & Itanhandu & Irmãos & 10 \\
\hline Heloísa & B & Feminino & $1^{\mathrm{a}}$ & Itanhandu & Irmão & 5 \\
\hline Fernanda & $\mathrm{A}$ & Feminino & $2^{a}$ & Itanhandu & Irmã & 0 \\
\hline Luiza & A & Feminino & $2^{a}$ & São Paulo & Não & 5 \\
\hline Clarice & A & Feminino & $2^{a}$ & Itanhandu & Irmãos & 0 \\
\hline Lorena & B & Feminino & $2^{a}$ & Itanhandu & Não & 9 \\
\hline Marcela & $\mathrm{B}$ & Feminino & $2^{a}$ & Itanhandu & Irmã & 12,5 \\
\hline Regina & B & Feminino & $2^{a}$ & Passa Quatro & Não & 11 \\
\hline Rose & A & Feminino & $3^{a}$ & Itanhandu & Não & 5 \\
\hline Luciana & A & Feminino & $3^{a}$ & Itanhandu & Irmãs & 10 \\
\hline Joana & A & Feminino & $3^{a}$ & Itanhandu & Não & 8 \\
\hline Rosângela & B & Feminino & $3^{a}$ & Itanhandu & Irmão & 22 \\
\hline Lúcia & $\mathrm{B}$ & Feminino & $3^{a}$ & Itanhandu & Irmãos & 18 \\
\hline Vânia & B & Feminino & $3^{a}$ & Alagoa & Irmão & 27 \\
\hline
\end{tabular}

Quadro 3: Informantes da amostra itanhanduense 
Assim que a gravação era encerrada, o documentador solicitava ao informante que assinasse uma declaração de consciência da gravação da entrevista e de reconhecimento de que seus dados pessoais não seriam divulgados publicamente.

\subsection{Tratamento dos dados}

Os áudios foram gravados em formato wav ou $\mathrm{mp} 3$, variando de acordo com o gravador utilizado. Utilizou-se o gravador Sony ICD-PX820 na coleta das dezoito primeiras entrevistas sociolinguísticas. Já na segunda metade da amostra, foi possivel utilizar o gravador Tascam DR-100, que possui qualidade bastante superior ao gravador empregado inicialmente.

Após coletadas, as 36 entrevistas sociolinguísticas foram transcritas semiortograficamente, segundo critérios do Grupo de Estudo em Sociolinguística da Universidade de São Paulo (GESOL - USP):

- Por não se tratar de uma transcrição fonética, a ortografia das palavras não foi alterada. Mesmo que, por exemplo, o falante tivesse pronunciado "minino", "rapidim", "purque", transcreveu-se "menino", "rapidinho" e "porque", respectivamente.

- Por outro lado, não foram feitas "correções" gramaticais. Por exemplo, se o informante pronunciou "os irmão que eu tenho", sem concordância nominal, foi transcrito dessa forma, ou seja, sem a concordância. Da mesma forma, se o informante pronunciou "Eu acho que que vou viajar", a transcrição foi realizada com a repetição da conjunção "que".

- Pontos finais e vírgulas não são utilizados por não corresponderem à realidade da língua oral. Entretanto, exclamações e interrogações são transcritas com seus respectivos símbolos ortográficos.

Os critérios gerais utilizados nas transcrições das entrevistas que formam a amostra itanhanduense estão disponiveis no Anexo IV.

Após as transcrições, as entrevistas foram ouvidas novamente para que cada ocorrência de (-r) pudesse ser marcada com <>, com uma letra no meio, que representava o código da variante de (-r) empregada naquela posição do vocábulo. Eram cinco as possibilidades de marcação: 
$\checkmark<$ F $>$ se a variante pronunciada fosse o retroflexo forte;

$\checkmark<\mathrm{C}>$ se a variante pronunciada fosse o retroflexo fraco;

$\checkmark<\mathrm{T}>$ para tepe;

$\checkmark<\mathrm{H}>$ para fricativo;

$\checkmark<$ A $>$ se o rótico fosse apagado;

$\checkmark<\mathrm{M}>$ se o dado correspondesse a um uso metalinguístico, ou seja, fosse um caso de imitação da fala de alguém. Por exemplo, em determinado momento da entrevista, um dos informantes poderia pronunciar o (-r) como fricativo porque estaria imitando um carioca.

Concluída a marcação de todas as ocorrências do rótico, utilizou-se um script do programa estatístico R (OUSHIRO, 2014), através de sua interface RStudio, para extrair automaticamente os dados. Como resultado, o programa forneceu uma tabela (excel) com os dados organizados. A Figura 14 traz uma seção da tabela gerada.

\begin{tabular}{|c|c|c|c|c|c|c|c|}
\hline B & c & & D & E & $\mathrm{F}$ & G & H \\
\hline Variavel.Dependente - & Contexto.Precedente & $\nabla$ & Ocorrencia & Contexto.Seguinte - & sexo.gene - & faixa.etar - & aus.de.identific \\
\hline A & que a cidade cresceu bastante & & que $\langle>\rangle$ & no bairro em que & $\mathrm{F}$ & 1 & A \\
\hline A & tem nem lote mais pra & & vender $\langle>\rangle$ & D1: entendi & $\mathrm{F}$ & 1 & A \\
\hline $\mathrm{F}$ & S1: nÃfo estÃi tendo & & lugar <F> & D1: entendi & $\mathrm{F}$ & 1 & A \\
\hline A & entÃfo estã̃i... ela abre pode & & deixar $\langle>>$ & que ela abre & $\mathrm{F}$ & 1 & A \\
\hline A & D1: uhum S1: & & comprar $\langle>>$ & D1: uhum & $\mathrm{F}$ & 1 & A \\
\hline $\mathrm{F}$ & agora eu nÃ fo sei o & & porquÃ̃a $<F\rangle$ & D1: uhum & $\mathrm{F}$ & 1 & A \\
\hline $\mathrm{F}$ & que estã̃i mais cara o & & lugar $\langle\mathrm{F}\rangle$ & que tem/ que nÃfo & $\mathrm{F}$ & 1 & A \\
\hline $\mathrm{F}$ & S1: Ã@ bem localizado sim & & porque $\langle F\rangle \ldots$ & Ã@ tudo perto $\langle F\rangle$ & $\mathrm{F}$ & 1 & A \\
\hline $\mathrm{F}$ & sim porque $<F>\ldots \tilde{A} \cong$ tudo & & perto <F> & $\mathrm{D} 1$ : perto & $\mathrm{F}$ & 1 & A \\
\hline A & D1: aham S1: pra & & poder $<>>$ & chegar $<>>$. entÃfo a & $\mathrm{F}$ & 1 & A \\
\hline A & S1: pra poder $\langle>\rangle$ & & chegar $\langle>\rangle$ & entÃ̃fo acho que aqui & $\mathrm{F}$ & 1 & A \\
\hline $\mathrm{F}$ & D1: aham S1: Ãœ & & perto <F> & de cidade grande que & $\mathrm{F}$ & 1 & A \\
\hline A & minha avÃ $\tilde{A}^{3}$ que [hes.] foi & & fazer $<>>$ & ressonÃcncia D1: entE & $\mathrm{F}$ & 1 & A \\
\hline A & igual minha avÃ $\tilde{A}^{3}$ que foi & & fazer $<>>$ & ressonÃ cncia S2: licer & $\mathrm{F}$ & 1 & A \\
\hline $\mathrm{F}$ & S1: entãfo pra um & & doutor <F> & trazer uma aparelhag & $\mathrm{F}$ & 1 & A \\
\hline A & muito cara pra ele vai & & ficar $\langle>>$ & difÃ̃-cil D1: uhum & $\mathrm{F}$ & 1 & A \\
\hline A & entÃfo Ã@ preferÃ-vel pra eles & & fazer $<>>$ & numa cidade maior $<\mathrm{F}$ & $\mathrm{F}$ & 1 & A \\
\hline $\mathrm{F}$ & eles fazer $<\mid>$ numa cidade & & maior $\langle\mathrm{F}\rangle$ & D1: ah entendi & $\mathrm{F}$ & 1 & A \\
\hline A & S1: e a cidade pequena & & recorrer $\langle/\rangle$ & D1: mas vocÃ̃a & $\mathrm{F}$ & 1 & A \\
\hline A & ah eu acho que poderia & & $\operatorname{dar}\langle>\rangle$ & $\operatorname{sim} n A \tilde{D} \odot \mathrm{D} 1:$ & $\mathrm{F}$ & 1 & A \\
\hline c & S1: estÃi trazendo muita gente & & porque $\langle C\rangle$ & estã̃i com os equipan & $\mathrm{F}$ & 1 & A \\
\hline A & gente vindo pra cÃi pra & & poder $\langle>\rangle$ & ser atendido nÃ $\odot$ & $\mathrm{F}$ & 1 & A \\
\hline $\mathrm{F}$ & entendi S1: entãfo com & & certeza 〈F> & daria certo $\langle\mathrm{F}\rangle$ & $\mathrm{F}$ & 1 & A \\
\hline $\mathrm{F}$ & entÃfo com certeza $<F>$ daria & & certo <F> & D1: aham & $\mathrm{F}$ & 1 & A \\
\hline A & S1: tem o PSF pra & & atender $\langle>\rangle$ & ... tem as agente & $\mathrm{F}$ & 1 & A \\
\hline c & vÃåm pelo menos uma vez & & por $<C>$ & mã̃as estã̃i na nossa & $\mathrm{F}$ & 1 & A \\
\hline
\end{tabular}

Figura 14: Tabela gerada pelo RStudio

$\mathrm{Na}$ coluna $\mathrm{B}$, estão os códigos correspondentes às variantes produzidas pelo informante. Nas colunas $\mathrm{C}$ e E estão os contextos precedentes e seguintes, respectivamente, às variantes. Já a coluna D traz os vocábulos em que os róticos foram realizados, enquanto as colunas $\mathrm{F}, \mathrm{G}$ e $\mathrm{H}$ trazem os grupos de fatores estratificadores da amostra (sexo/gênero, faixa etária e identificação do informante com a cidade respectivamente).

Alguns erros de incompatibilidade de fontes podem ocorrer. O pesquisador deve corrigi-los manualmente antes de prosseguir na codificação 
dos dados. A partir daí, cabe ao pesquisador codificar cada dado de acordo com os demais grupos de fatores a serem considerados na análise que deseja realizar. Para esta pesquisa, conforme se detalha no capitulo a seguir, os dados foram codificados para um total de treze grupos de fatores.

Após a codificação dos dados, criou-se, na coluna A, um amálgama formado por todos os grupos de fatores a serem considerados na análise. Parte do amálgama gerado pode ser visualizada na Figura 15.

\begin{tabular}{|c|c|c|c|c|c|c|c|c|c|}
\hline$\Delta$ & A & B & c & D & E & $\mathrm{F}$ & G & H & \\
\hline 1 & Amálgama & velDepe & nforma $-\pi$ & exo/Gêl & FaixaEta & entific & ItemLexical & quência do item & - \\
\hline 13869 & (AF3AbaftvfLEOM nasci mas aí eu fui [ $[\epsilon$ & A & Joana & $\mathrm{F}$ & 3 & A & estudar & 110 & \\
\hline 13870 & (AF3Ac3wtvfLEOM aqui [risos - S1, D1] [l & A & Joana & $\mathrm{F}$ & 3 & A & quer & 261 & \\
\hline 13871 & (AF3AbentvfLEOM - S1, D1] quer $\langle/>$ [[ $d$ & A & Joana & $\mathrm{F}$ & 3 & A & dizer & 166 & \\
\hline 13872 & (FF3Aaom1vmLEOM não lembro quandc & $\mathrm{F}$ & Joana & $\mathrm{F}$ & 3 & A & formei & 9 & \\
\hline 13873 & (FF3Aaom 1vmLEOM fiquei cinco anos fc & $\mathrm{F}$ & Joana & $\mathrm{F}$ & 3 & A & formei & 9 & \\
\hline 13874 & (AF3AceftvfLEOM isso setenta e oito fiu & A & Joana & $\mathrm{F}$ & 3 & A & fazer & 383 & \\
\hline 13875 & (AF3AbaltvfLETM S1: quando eu começe & A & Joana & $\mathrm{F}$ & 3 & A & trabalhar & 170 & \\
\hline 13876 & (AF3Acok1cmLEOM preocupação era arr & A & Joana & $\mathrm{F}$ & 3 & A & porque & 1695 & \\
\hline 13877 & (AF3Acok1cmLEOM de confiança S1: é [I & A & Joana & $\mathrm{F}$ & 3 & A & porque & 1695 & \\
\hline 13878 & (AF3AaaftvfLEOM isso tranquilidade de & A & Joana & $\mathrm{F}$ & 3 & A & criar & 13 & \\
\hline 13879 & (AF3AcoktcfLEOM que [hes.] a gente sai & A & Joana & $\mathrm{F}$ & 3 & A & por & 762 & \\
\hline 13880 & (FF3AaimtsmLEDM Belo Horizonte mas 1 & $\mathrm{~F}$ & Joana & $\mathrm{F}$ & 3 & A & firma & 22 & \\
\hline 13881 & (HF3AbentsmLEDM firma $<F>$ que era dc & $\mathrm{H}$ & Joana & $\mathrm{F}$ & 3 & A & governo & 55 & \\
\hline 13882 & (AF3AbaktvfLEFM cá ser autônomo aqui & A & Joana & $\mathrm{F}$ & 3 & A & trabalhar & 170 & \\
\hline 13883 & (AF3AcamtsfLEOM eu pedi transferêncié & A & Joana & $\mathrm{F}$ & 3 & A & lugar & 186 & \\
\hline 13884 & (HF3Ac3ttamLEOM para o lugar $</>$ mais & $\mathrm{H}$ & Joana & $\mathrm{F}$ & 3 & A & perto & 202 & \\
\hline 13885 & (FF3Ac3ttamLEOM onde tinha o banespi & $\mathrm{F}$ & Joana & $\mathrm{F}$ & 3 & A & perto & 202 & \\
\hline 13886 & (AF3Acok1cmLEOM acha?... S1: ah entãc & A & Joana & $\mathrm{F}$ & 3 & A & porque & 1695 & \\
\hline 13887 & (FF3Ab3ttamLEOM porque $</>$ não tinha & $\mathrm{F}$ & Joana & $\mathrm{F}$ & 3 & A & certo & 133 & \\
\hline 13888 & (CF3AaimtsmLEOM S1: ele estava em un & C & Joana & $\mathrm{F}$ & 3 & A & firma & 22 & \\
\hline 13889 & (AF3AcaftvfLEOM aí o pessoal que fosse & A & Joana & $\mathrm{F}$ & 3 & A & ficar & 188 & \\
\hline 13890 & (AF3Acok1cmLEOM D1: uhum S1: [[ porc & A & Joana & $\mathrm{F}$ & 3 & A & porque & 1695 & \\
\hline
\end{tabular}

Figura 15: Exemplo de codificação dos dados feita no Microsoft Excel 2010

Uma vez gerado o amálgama com a totalidade de dados de (-r) codificados para as variáveis independentes consideradas, a coluna A foi copiada para o programa estatístico GoldVarb X. A partir daí, deu-se início à análise multivariada dos dados.

\subsection{Paradigmas da análise quantitativa}

Acerca do paradigma quantitativo, Oushiro (2011) afirma que

se baseia no conceito de competência comunicativa: os membros de uma comunidade têm internalizadas não apenas as regras da gramática mas também as regras de seus usos apropriados, de forma semelhante ao domínio de outras regras culturais (Sankoff, 1980). A partir da premissa de que as flutuações observadas na língua em uso são ordenadas e formam padrões, o paradigma quantitativo busca modelar a 
competência comunicativa do falante através de um conjunto de princípios teóricos. (OUSHIRO, 2011: 13-14).

Acerca dos princípios teóricos, Bayley (2003) propõe a existência de dois dentro do paradigma quantitativo. O primeiro deles é o Princípio do Modelo Quantitativo, que postula a natureza quantitativa da correlação entre as formas variantes de uma variável e o contexto linguístico e social em que elas se realizam. A partir de uma grande quantidade de dados, é possivel verificar padrões de variação.

O segundo principio é o das Múltiplas Causas, de acordo com o qual é improvável que um único fator (linguístico ou extralinguístico) seja capaz de explicar a variabilidade observada nos dados de línguas naturais. Muitos estudos sociolinguísticos têm de fato evidenciado que as variáveis se correlacionam com múltiplos fatores.

Aproximando-se do Princípio do Modelo Quantitativo, Guy (2007) propõe que, para estudar tanto a estrutura linguística quanto a estrutura social, é necessária a coleta de grande quantidade de dados (GUY, 2007). Esses dados, além de serem representativos das comunidades de fala investigadas, devem obedecer a um "controle de qualidade".

A necessidade de se trabalhar com grande quantidade de dados vem do fato de que a variação linguística não é "aleatória" ou "livre", mas segue um padrão - o que é chamado por Weinreich, Labov e Herzog (2006 [1975]) de "heterogeneidade ordenada". Por esse motivo, quando se atribui certa característica linguística a uma comunidade de fala ou grupo de indivíduos é necessário apoiar-se na análise estatística de muitos dados coletados dentro desses grupos, pois só analisando muitas ocorrências é possivel perceber a manifestação dessa "heterogeneidade ordenada".

Faz-se necessária também a coleta de grande quantidade de dados porque não há como falar com segurança acerca das características de um dialeto apoiando-se apenas em poucos dados (GUY, 2007; MARTINS, 2006). Pode haver uma cidade ou região que não se insira totalmente dentro de uma isoglossa ou que não se insira em só uma delas, quando se consideram diferentes aspectos linguísticos. Esse é o caso da cidade sul-mineira investigada neste trabalho. Por isso, parece que quanto maior a quantidade de dados de que se dispõe, mais confiável se torna a análise feita deles. 
Por suas enormes contribuições é que os estudos sociolinguísticos têm, cada vez mais, utilizado a metodologia quantitativa de análise de dados. O ponto mais importante é que esta metodologia permite medir estatisticamente eventuais correlações entre a variação em foco e determinado grupo de fatores.

O uso desse pacote estatístico difere de outros que também realizam análise multivariada, pois considera as ações dos diferentes grupos de fatores sobre as variantes como independentes entre si. Entretanto, deve-se estar sempre atento a interações entre grupos de fatores, caso em que variáveis independentes deixam de agir dessa forma. Quando interações ocorrem, o programa não funciona da melhor maneira e pode fornecer dados enviesados. O mesmo ocorre quando as células formadas pelo cruzamento de grupos de fatores distintos revelam-se vazias ou com pouca quantidade de dados. Estes aspectos serão tratados mais detalhadamente, quando for o caso, nos Capitulos 4 e 5 .

A seguir, o Capitulo 3 apresenta os primeiros trabalhos realizados sobre a variável (-r) e algumas pesquisas já desenvolvidas no Brasil sobre esse mesmo tema. 


\section{Capitulo 3: A variável (-r)}

A revisão bibliográfica sobre (-r) tem como objetivo retomar os primeiros estudos sociolinguísticos sobre o tema, mostrar um panorama do estudo desse elemento fônico no Brasil, indicando as poucas pesquisas sobre tal variável em regiões de divisa estaduais e, assim, reforçar o interesse de se estudar Itanhandu.

Serão retomados dois trabalhos seminais sobre tema, Labov (1966) e McDavid's (1948 apud CASEY, 2013). Após, serão discutidos alguns trabalhos brasileiros sobre tal variável, com destaque para os estudos já feitos sobre ela em São Paulo, Rio de Janeiro e Minas Gerais, os três estados imbricados na "composição linguística" de Itanhandu.

No tocante a São Paulo, são retomados os trabalhos que investigam apenas a capital paulista, algo que difere do que se faz com os estados de Minas Gerais e Rio de Janeiro, em que se consideram não só suas capitais. Tal diferença se justifica na medida em que se aventa a hipótese da influência da cidade de São Paulo (com seu (-r) tepe) e do estado do Rio de Janeiro (com o seu emprego majoritário de fricativas velares e aspiradas) nos usos linguísticos itanhanduenses.

Os estudos sociolinguísticos sobre o (-r) tiveram em McDavid's (1948 apud CASEY, 2013) e Labov (1966) seus precursores. Dentro do território norte-americano, McDavid's investigou tal elemento na Carolina do Sul e Labov realizou um estudo na cidade de Nova York.

Ao investigar o (-r) pós-vocálico, Labov (1966) constatou que, no dialeto nova-iorquino - em que tipicamente não se realizava o (-r) - tinha início um processo de mudança pelo qual tal elemento vinha sendo mais frequentemente realizado. Na terminologia do autor, $\mathrm{R}-\mathrm{O}$ - (a variante apagamento), através de uma mudança lenta na comunidade, caminhava em direção a R-1 (a realização do (-r), a variante prestigiada dentro da comunidade).

Labov verificou que as realizações de (-r) pós-vocálico estavam fortemente correlacionadas a determinadas variáveis sociais, tais como: (a) classe social; (b) estilo (enquanto atenção dada à fala pelo próprio informante LABOV, 1966); (c) acentuação e (d) contexto fônico seguinte. 
Os membros de classes mais altas tendiam a realizar mais o (-r) pósvocálico em todos os contextos (linguísticos e não linguísticos), assim como, em um estilo mais formal, todos os informantes tendiam a usar mais o (-r) (relativamente ao estilo menos monitorado ou "casual").

No Brasil, os estudos dialetológicos e sociolinguísticos acerca do (-r) começam, sobretudo, com o interesse de encontrar fenômenos fonéticos capazes de embasar uma proposta de divisão dialetal do país (NASCENTE, 1953; 1958; SILVA NETO, 1963).

Ao lado de outros fenômenos fonéticos, como a realização das vogais pretônicas ou das consoantes fricativas surdas e sonoras [s] e $[z]$ em coda silábica, a pronúncia variável do (-r) tem despertado o interesse de muitos estudiosos no Brasil, conforme já se citou anteriormente na Introdução.

De acordo com Cristófaro Silva (2002 [1998]: 142 e 143), os sons de /R/ no PB são distintos acusticamente. Para a autora, são sete as possibilidades de realização deste som consonantal:

- X (fricativa velar desvozeada), como em "carta" ['caX.ta]. A autora chama essa realização de "pronúncia típica do dialeto carioca";

- y (fricativa velar vozeada), como em ['kay.ga], também pertencente ao dialeto carioca;

- h (fricativa glotal desvozada), como em ['mah], que a autora chama de "pronúncia típica de Belo Horizonte";

- h (fricativa glotal vozeada), como em ['kaf.ga], também atribuída a Belo Horizonte;

- ؟ (tepe alveolar vozeado), como em ['bar];

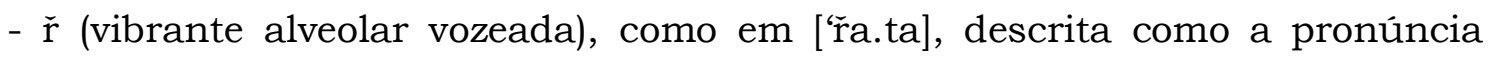
típica do português europeu e de alguns dialetos do português paulista;

- . I (aproximante alveolar), atribuída ao "dialeto caipira”.

Callou et al. (1998) destacam a alta variabilidade do rótico em posição de coda, interna (meio da palavra) ou externa (no fim da palavra), e afirmam que tal variabilidade pode estar correlacionada não só com fatores estruturais da língua, mas também com fatores sociais.

Segundo Mendes e Oushiro (2011), os inúmeros trabalhos realizados sobre a distribuição e condicionamentos das variantes de /R/, “(..) destacam a alta variabilidade de sua realização, tanto em posição de ataque ou coda silábica, em meio ou final de palavra, e a sua saliência como indexicalizador 
de identidades sociais - diatópicas, diastráticas e diafásicas”. (MENDES; OUSHIRO, 2011: 229).

Em meados dos anos 90, Callou, Moraes e Leite (1996) investigaram a produção de (-r) em cinco capitais brasileiras: Porto Alegre, São Paulo, Rio de Janeiro, Salvador e Recife. A partir de uma distribuição geral dos dados, sem considerar fatores linguísticos e sociais, as autoras observaram que a vibrante apical simples (tepe) (32\% dos casos) é a mais frequente, seguida de apagamento (26\% dos casos), fricativa velar (21\% dos casos) e, finalmente, fricativa laríngea (aspirada) (18\% dos casos). A vibrante uvular também ocorre no corpus, mas representa apenas $1 \%$ dos dados.

Nesse mesmo estudo, as autoras mostram que o tepe é a variante que caracteriza linguisticamente a região sul, o que inclui Porto Alegre e São Paulo, ao passo que Rio de Janeiro, Recife e Salvador possuem as fricativas velares e aspiradas como suas marcas linguísticas.

Monaretto (1997) constatou que o emprego das variantes do rótico encontra-se correlacionado principalmente ao contexto silábico em que o (-r) aparece e às localidades geográficas a que pertencem os informantes.

Em trabalho posterior, Monaretto (2002) investigou o (-r) em três amostras da fala de Porto Alegre extraídas de três corpora coletados em épocas distintas: (i) Nurc, 1970; (ii) Varsul, 1989 e (iii) Varsul ampliada, 1999. Neste estudo, a autora verificou um alto índice de apagamento do elemento rótico (25\%), predominância da forma tepe e baixa frequência de emprego da fricativa velar (1\%), da vibrante alveolar (9\%) e da forma retroflexa (5\%).

Já no estudo realizado em 2009, Monaretto investigou as realizações do (-r) nos três estados que formam a região Sul do Brasil - nas cidades de Porto Alegre, Flores da Cunha, Panambi, Florianópolis, Lages, Blumenau, Chapecó, Curitiba, Londrina e Pato Branco. Nos três estados investigados, a pesquisadora percebeu a presença de variantes anteriores (vibrantes e fricativas) seja em posição de ataque ou em posição de coda silábica, e afirmou que essas realizações se tornam marcas típicas da variedade do português falado por lá, não só pela alta frequência (95\% dos casos de / R/ em ataque e $71 \%$ dos casos de /R/ em coda) em que ocorrem, mas também por sua distribuição em todo território geográfico da região. A autora afirma ainda que a variante retroflexa é pouco frequente (5\% dos dados) no corpus investigado, com exceção do estado do Paraná, em que essa forma mostra-se bastante produtiva. 
Monguilhott (1998), que investigou a realização de (-r) nas cidades catarinenses de Lages, Blumenau, Chapecó e Florianópolis, verificou o predomínio da forma fricativa na capital catarinense, enquanto a forma tepe mostrou-se mais frequente nas demais localidades. A autora verificou também uma correlação entre a etnia (alemães, açorianos, italianos) presente nas cidades investigadas, todas elas resultados de imigrações, e as produções linguísticas constatadas.

Em 2007, Monguilhott investigou a variação do (-r) em diferentes pontos da cidade de Florianópolis. Das 173 ocorrências do rótico em posição de coda (final ou medial), 60\% são de fricativa glotal, $24 \%$ de fricativa velar e $16 \%$ da variante tepe. Segundo a autora, as fricativas variam seu vozeamento de acordo com o contexto linguístico em que ocorrem.

Os estudos sobre o rótico no sul do Brasil evidenciaram a predominância por lá das variantes fricativas e vibrantes, com exceção do estado do Paraná, em que há certa hegemonia do (-r) retroflexo. Assim, vê-se que o uso da forma retroflexa liga-se mais aos estados ao norte (Paraná, Minas Gerais, Mato Grosso, por exemplo) em relação às regiões investigadas.

\section{São Paulo}

Um dos primeiros estudos sociolinguísticos realizados sobre o português paulistano foi empreendido por Callou, Moraes e Leite (1996) com dados do NURC - SP - projeto que teve o objetivo de caracterizar a modalidade culta da lingua falada em cinco capitais brasileiras.

$\mathrm{Na}$ cidade de São Paulo, as autoras constataram que a pronúncia mais frequente para o (-r) é o tepe, com uma taxa de $41 \%$ quando o (-r) encontra-se em final de palavra (neste contexto ocorre apagamento em $47 \%$ dos dados), e $87 \%$ em posição medial. Elas constataram ainda que, nos estados ao norte de São Paulo, a produção de tepe é bastante infrequente, tanto em posição final quanto em posição medial. Já as taxas de realização da variante retroflexa na cidade de São Paulo foram bastante baixas: $5 \%$ em meio de palavra e $2 \%$ em contexto final.

Entretanto, o português paulistano, no que tange especificamente à distribuição e aos condicionamentos das variantes de (-r), sobretudo em relação a grupos de fatores sociais, tem sido apenas recentemente estudado (OUSHIRO; MENDES, 2013; MENDES; OUSHIRO, 2012; MENDES; OUSHIRO, 
2011; MENDES, 2010; SANTOS, 2012; VIEIRA, 2014; SORIANO, 2014; GOMES DA SILVA, 2014; OUSHIRO, 2015).

A partir de uma amostra de 24 falantes paulistanos "prototípicos" (nascidos em bairros mais centrais ${ }^{27}$ e identificados com as noções de "paulistanidade" e "cosmopolitismo") estratificados de acordo com seu sexo/gênero, três faixas etárias e dois níveis de escolarização, Mendes (2010) verificou uma taxa de $12 \%$ de ocorrência da variante retroflexa e um indício de mudança em progresso a favor da variante tepe.

Já Mendes e Oushiro (2011b), valendo-se de uma amostra de 48 informantes estratificados da mesma maneira que no trabalho anterior, constataram uma taxa média de $31 \%$ de uso do retroflexo na capital paulista e um indicativo de variação estável na comunidade.

Em 2012, Oushiro e Mendes realizaram outra pesquisa sociolinguística na cidade de São Paulo. Desta vez, com 102 entrevistas sociolinguísticas coletadas junto a informantes paulistanos ou que se mudaram para a cidade antes dos 10 anos de idade e viveram ali a maior parte de suas vidas. Os informantes foram estratificados de acordo com quatro variáveis sociais: (i) Sexo/Gênero (masculino, feminino); (ii) Faixa Etária (20 a 34 anos, 35 a 59 anos, 60 anos ou mais); (iii) Nivel de Escolaridade (até Ensino Médio, Curso Superior); e (iv) Região de Residência (bairro mais central, bairro mais periférico).

Os pesquisadores evidenciaram a presença da pronúncia retroflexa em $33,2 \%$ dos casos em 25.950 ocorrências - apesar de ser essa uma variante desprestigiosa entre os paulistanos "prototípicos".

Em análise recente, Oushiro (2015) investigou a fala paulistana através de 118 entrevistas sociolinguísticas estratificadas tal como em Oushiro; Mendes (2012). Como resultado, a pesquisadora encontrou uma taxa média de $28,3 \%$ para a realização do retroflexo e um indicativo de variação estável na comunidade, resultado que se mostrou consonante com os de Mendes; Oushiro (2011b). Na Tabela 3 a seguir, comparam-se esses estudos:

\footnotetext{
${ }^{27}$ O termo "central" refere-se não só ao centro da cidade de São Paulo, mas também a outros bairros que ocupam uma posição mais centralizada dentro da capital.
} 
Tabela 3: Taxas do retroflexo em diferentes amostras em São Paulo (adaptado de

OUSHIRO, 2015)

\begin{tabular}{|c|c|c|c|c|}
\hline & $\begin{array}{c}\text { Mendes } \\
2010\end{array}$ & $\begin{array}{l}\text { Mendes; } \\
\text { Oushiro } \\
2011 \mathrm{~b}\end{array}$ & $\begin{array}{l}\text { Oushiro; } \\
\text { Mendes } \\
2012 \\
\end{array}$ & Oushiro 2015 \\
\hline $\begin{array}{l}\text { Tamanho e } \\
\text { estratificação } \\
\text { da amostra }\end{array}$ & $\begin{array}{l}24 \text { falantes } \\
\text { Sexo/Gênero } \\
\text { Faixa Etária } \\
\text { Escolaridade }\end{array}$ & $\begin{array}{l}48 \text { falantes } \\
\text { Sexo/Gênero } \\
\text { Faixa Etária } \\
\text { Escolaridade }\end{array}$ & $\begin{array}{c}102 \text { falantes } \\
\text { Sexo/Gênero } \\
\text { Faixa Etária } \\
\text { Escolaridade } \\
\text { Região } \\
\end{array}$ & $\begin{array}{c}118 \text { falantes } \\
\text { Sexo/Gênero } \\
\text { Faixa Etária } \\
\text { Escolaridade } \\
\text { Região }\end{array}$ \\
\hline $\begin{array}{l}\text { Taxa de } \\
\text { retroflexo }\end{array}$ & $12,0 \%$ & $31,0 \%$ & $33,2 \%$ & $28,3 \%$ \\
\hline $\begin{array}{l}\text { Análise em } \\
\text { tempo } \\
\text { aparente }\end{array}$ & $\begin{array}{l}\text { Mudança em } \\
\text { favor do tepe }\end{array}$ & $\begin{array}{l}\text { Variação } \\
\text { estável }\end{array}$ & $\begin{array}{c}\text { Variação } \\
\text { estável }\end{array}$ & $\begin{array}{c}\text { Variação } \\
\text { estável }\end{array}$ \\
\hline
\end{tabular}

Os três trabalhos mais recentes se aproximam entre si e, ao mesmo tempo, distanciam-se de Mendes (2010). Segundo Oushiro (2015):

\begin{abstract}
Os motivos para as diferentes conclusões certamente residem nas amostras utilizadas que, apesar de semelhantes, guardam certas propriedades: a amostra de Mendes (2010) restringiu-se a falantes mais prototípicos, residentes em bairros mais tradicionais em São Paulo e que se identificam com a cidade; Mendes \& Oushiro (2011b), ao aumentar a amostra de informantes, não levaram em consideração tal critério; a presente análise, por sua vez, incluiu na estratificação dos falantes a variável Região de Residência, que se revelou como uma das mais importantes para a pronúncia de $(-r)$. As taxas semelhantes (cerca de 30\% de emprego do retroflexo) nas duas amostras maiores permite concluir que essa deve ser a proporção atual da variante no português paulistano de modo geral. (OUSHIRO, inédito: 111-112).
\end{abstract}

Em um estudo realizado com os dados coletados pelo $\mathrm{ALiB}^{28}$, Castro (2009) investigou 38 localidades do estado de São Paulo (capital e interior). Em coda interna, o (-r) foi realizado como retroflexo em $27 \%$ dos casos na capital. Esse índice foi muitíssimo maior nas cidades interioranas, chegando a $93 \%$. Em coda final, o retroflexo ocorreu em $17 \%$ das realizações entre os paulistanos e $92 \%$ entre os paulistas do interior.

É importante destacar a confluência dos trabalhos de Mendes e Oushiro (2011b), Oushiro e Mendes (2012), Oushiro (2015) e Castro (2009), já que todos apontam para uma taxa próxima de realização de [.] na cidade de São

${ }^{28}$ http://twiki.ufba.br/twiki/bin/view/Alib/WebHome

Último acesso em 08 de Junho de 2015. 
Paulo, cerca de $30 \%$ dos dados (considerando, para o trabalho de Castro (2009), os casos de coda interna).

Os trabalhos citados mostram uma presença bastante notável do retroflexo na cidade de São Paulo, todos os trabalhos citados, com exceção de Callou, Moraes e Leite (1996), mostram uma taxa de cerca de 30\% de realização do retroflexo, mesmo se tratando de uma comunidade de fala em que há a supremacia do tepe. A divergência entre os resultados encontrados na primeira pesquisa realizada sobre o (-r) na capital paulista e os demais trabalhados pode estar relacionada aos diferentes corpora analisados. Callou, Moraes e Leite (1996) trabalham com dados da fala culta paulistana, ou seja, são considerados apenas dados de pessoas mais escolarizadas e que, talvez por isso, tendam a evitar o uso da forma menos prestigiosa na capital, o (-r) retroflexo.

Em uma análise acústica do tepe, variante do rótico mais frequentemente empregada na capital paulistana, Silva (1996) verificou que esse som se caracteriza por ter curta duração, descontinuidade espectral marcada por um espaço praticamente vazio e com energia bastante baixa, seguida por uma batida e retomada do vozeamento.

A seguir, pode-se visualizar um espectrograma da variante tepe.

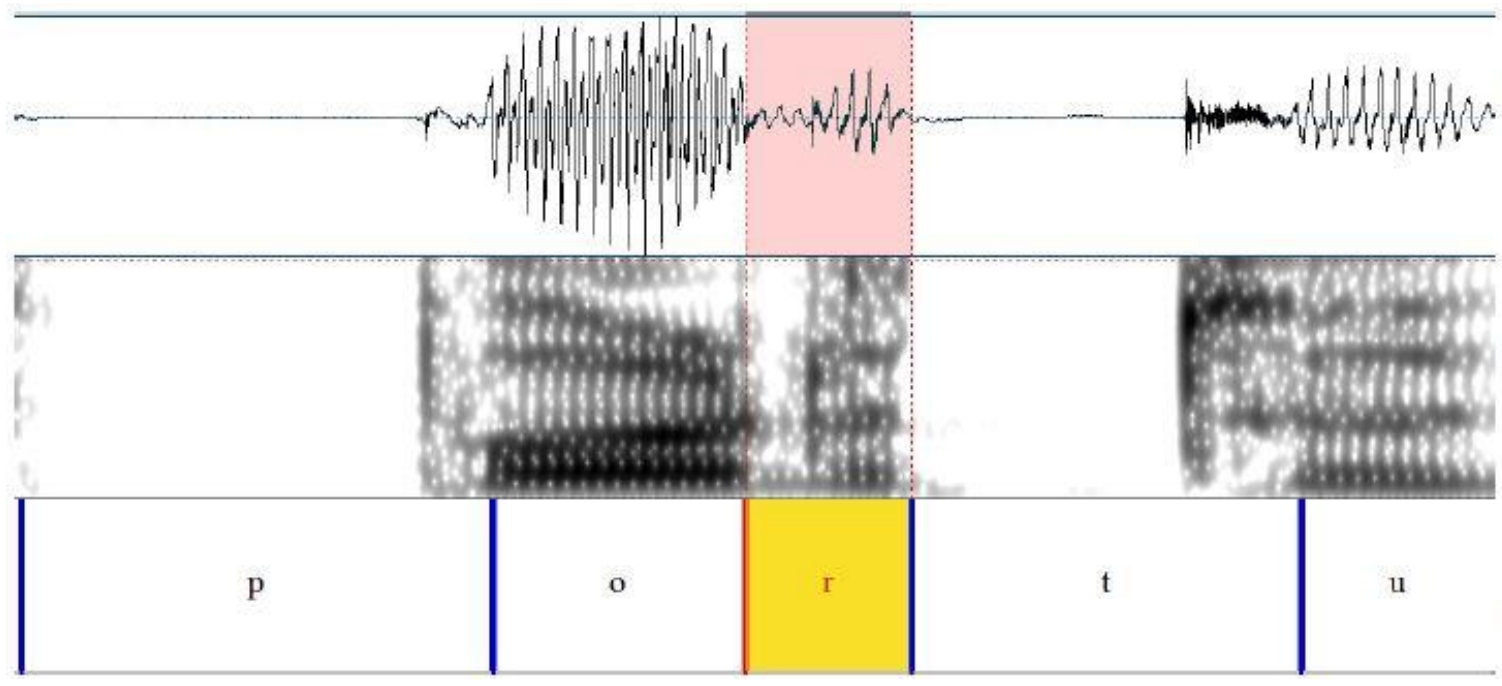

Figura 16: espectrograma da sequência "portu" retirada do vocábulo "portugueses"; traçado de forma da onda corresponde a (a), espectrograma de banda larga corresponde a (b) e transcrição ortográfica corresponde a (c) (GRECIO, 2012: 87) 


\section{Rio de Janeiro}

A respeito do Rio de Janeiro (cidade e estado), as pesquisas sociolinguísticas são mais numerosas (CALLOU, 1987; BRANDÃO, 1988, 1995, 1997, 2007, 2008; BRANDÃO; BRACONI, 2012; CALLOU; MORAES; LEITE, 1996; NARO; SCHERRE, 2004; SCHERRE, 1998, 2007).

Se no item anterior, a preocupação foi descrever as pesquisas sociolinguísticas sobre (-r) na cidade de São Paulo, aqui a preocupação será a de descrever os estudos realizados no estado fluminense. Essa distinção de tratamentos é consequência, conforme dito anteriormente, dos interesses da pesquisa apresentada neste trabalho. Em Itanhandu, além da pronúncia retroflexa, o (-r) pode ser realizado também à maneira fricativa (o que parece ser uma marca de todo o Estado do Rio de Janeiro e não só da capital) ou tepe (característico da capital paulista, conforme visto no item anterior).

Brandão (1988), em uma pesquisa de cunho dialetológico, investigou a fala de comunidades pesqueiras (Mundéus, São Benedito, Furadinho, Ponta Grossa dos Fidalgos, e Farol de São Tomé) de perfil rural no município de Campos, na região norte do estado do Rio de Janeiro. Seu interesse foi buscar uma descrição e explicação mais ampla para o retroflexo em um estado fortemente caracterizado pelas fricativas.

Para a coleta dos dados, a pesquisadora aplicou um questionário de 145 perguntas a um homem (de 34 a 47 anos) de cada comunidade - das quais 71 enfocavam / R/ em diferentes contextos. Na amostra recolhida, as ocorrências de retroflexo se realizaram nos seguintes contextos linguísticos: intervocálico $\left(V_{-} V\right)$, em ataque complexo de sílaba $\left(C_{-} V(C)\right)$ e em final de sílaba interna $\left((\mathrm{C})(\mathrm{C}) \mathrm{V}_{-}\right)$.

Nas palavras da pesquisadora,

Há, ainda, a mencionar o forte contraste entre as realizações dos informantes, que acabam por distribuir-se em dois grupos. Do primeiro, fazem parte os representativos de Mundéus, Furadinho e Farol de São Tomé, em cuja fala predominava a retroflexa. Do segundo, constam os de São Benedito e Ponta Grossa dos Fidalgos, que tinham no tepe e na fricativa velar/vibrante alveolar/tepe sua norma de pronúncia, respectivamente nos contextos $\mathrm{V}-\mathrm{V}, \mathrm{C}-\mathrm{V}$ e no contexto interno (C)(C) V-. (BRANDÃO, 2007: 275). 
O trecho acima evidencia a existência de outras variantes de (-r) no estado do Rio de Janeiro (inclusive da retroflexa), para além da majoritária presença da variante fricativa.

Em pesquisas mais recentes, BRANDÃO (1995, 1997 apud BRANDÃO, 2007) desenvolve um estudo sociolinguístico sobre o (-r) em 13 comunidades do norte e do noroeste do estado do Rio de Janeiro. Ela constata que “(...) em contexto interno, num total de 1.845 ocorrências, $(5 \%)$, correspondiam ao tepe, $21 \%$ à vibrante alveolar, 13\% à aproximante retroflexa, 44\%, à fricativa velar, 8\% à aspirada e 10\% a cancelamento". (BRANDÃO, 2007: 276).

Todos esses trabalhos - Brandão (1988; 1995; 1997) - evidenciam variação na pronúncia do (-r) no Rio de Janeiro, mas deixam claro que, a despeito da variação observada, as variantes fricativas (velar e aspirada) se realizam com maior frequência em todo o estado $(52 \%$ das ocorrências nas regiões norte e noroeste).

Segundo Kent e Read (1992), as variantes fricativas, aquelas mais frequentemente empregadas no estado do Rio de Janeiro, caracterizam-se por uma "estreita aproximação dos articuladores, que gera turbulência na corrente de ar em determinado ponto do trato vocal" (KENT; READ, 1992 apud GRECIO, 2012: 82). Os pontos de articulação dessa variante podem ser velar, uvular ou glotal. Do ponto de vista acústico, esse tipo de rótico apresenta ruído contínuo, alterando a faixa de frequência de amplificação do ruído de acordo com o ponto de articulação.

As variantes fricativas formam um traçado de forma de onda através de um sinal aperiódico, que ocorre simultaneamente ao ruído contínuo que aparece no espectrograma de banda larga (GRECIO, 2012).

A seguir, pode-se visualizar o espectrograma do vocábulo "cerca" em que o (-r) é produzido como uma variante fricativa. 


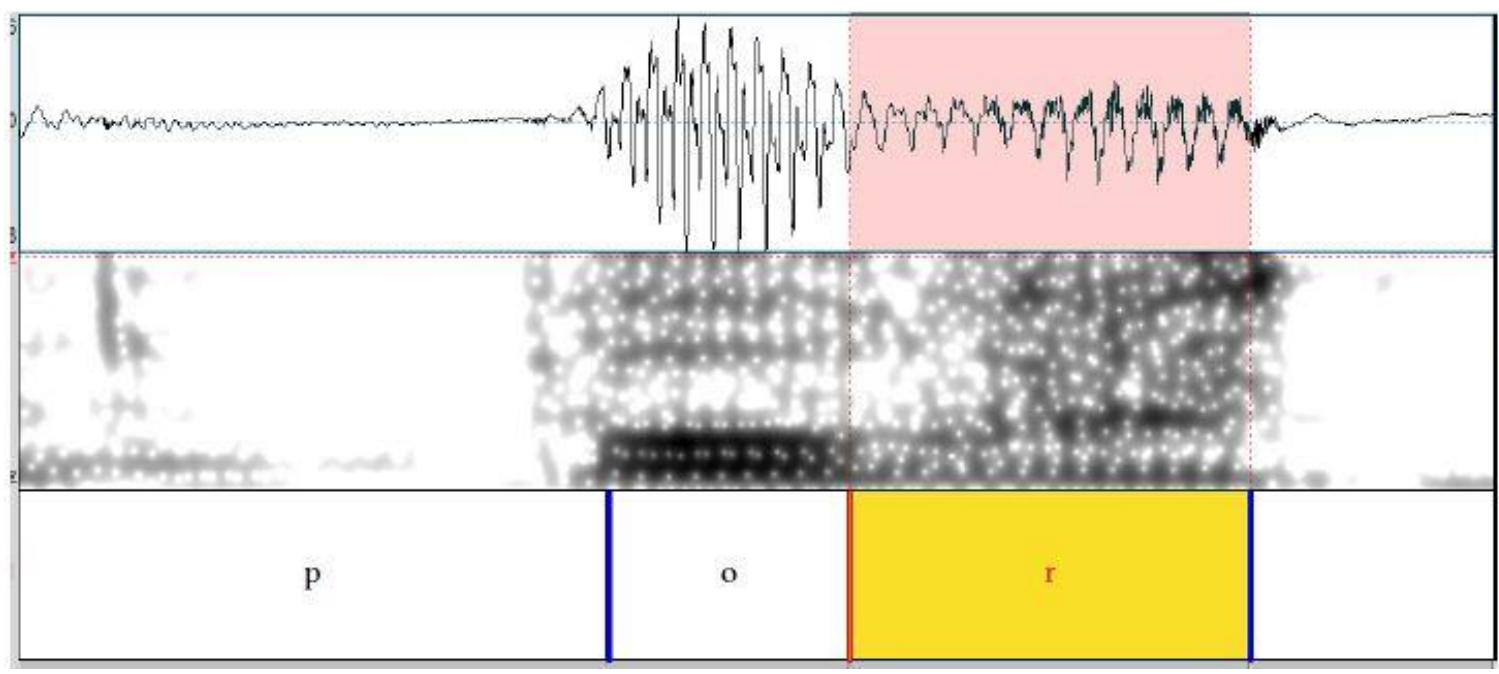

(a)

(b)

(c)

Figura 17: espectrograma do vocábulo "por"; traçado de forma da onda corresponde a (a), espectrograma de banda larga corresponde a (b) e transcrição ortográfica corresponde a (c) (GRECIO, 2012: 88)

É importante destacar que, neste trabalho, as diferenças acústicas e articulatórias entre fricativas velares e fricativas laringeas (aspiradas) não foram consideradas em detrimento de um mesmo significado social atribuído pelos itanhanduenses (BIELER, 2012) a esses alofones de /R/, nomeados, de modo geral dentro deste trabalho, como fricativas.

A produção das fricativas velares e aspiradas é uma característica fortemente relacionada e atribuída ao estado do Rio de Janeiro (CALLOU; MORAES; LEITE, 1996), apesar das fricativas também fazerem parte da realidade da capital mineira (GRECIO, 2012). Nesse sentido, os itanhanduenses parecem avaliar a realização dessa variante na mesma direção, uma vez que entendem as fricativas como uma característica dos cariocas ou daqueles que desejam "se passar" (sociolinguisticamente) por cariocas.

\section{Minas Gerais}

Conforme já se mencionou na Introdução, ZÁGARI (2005) propõe divisão dos falares mineiros em três sub-regiões distintas:

(i) um falar abaianado que, partindo do Norte vai até a linha, no sentido Leste-Oeste, que abarca as localidades de Mantena, Galileia, Governador Valadares, Nacip Raydan, Água Boa, São Sebastião do Maranhão, Itamarandiba, Várzea da Palma, João Ribeiro e termina em Paracatu (...).

(ii) um falar apaulistado que, partindo do Sul, na cidade de Passa Vinte e, rumando para o Norte, pega Liberdade, Andrelândia, Lavras, Oliveira, Pará de Minas, Divinópolis e, 
dobrando para o Oeste, vai até Vazante, passando por Bom Despacho, Dores do Indaiá, São Gotardo, Patos de Minas e São Gonçalo do Abaeté, englobando o Sul e o Triângulo (...). (iii) um falar mineiro (utilizando-se a nomenclatura de Nascente, 1958), preso entre essas duas áreas, além de não possuir as características acima enumeradas, desfaz constantemente os ditongos [ay], [ey], [oy], quando tônicos e não finais, como em ['kala], [mi'neru] ou ['toru] (...). (grifos do autor). (ZÁGARI, 1996:16 e 17)

Não se pode negar a contribuição de ZÁGARI (2005) e RIBEIRO et al. (1977) para o conhecimento linguístico que se tem sobre o estado de Minas Gerais. Entretanto, deve-se atentar para o fato de que certas generalizações podem esconder especificidades (sub-regionais, por exemplo).

O trabalho de LOURDES (2011) destaca a existência de uma cidade no triângulo mineiro, chamada Patos de Minas, em que o (-r) retroflexo não é um fato linguístico na fala de todos os habitantes. Apesar de localizada numa região de sotaque próximo ao do interior de São Paulo (de acordo com RIBEIRO et al., 1977 e ZÁGARI, 2005), essa pronúncia aparece em poucos casos e é mais comum na fala de pessoas que têm mais de 50 anos.

Em suas considerações sobre o "falar apaulistado", Zágari (1996) chega a mencionar que há, em algumas localidades que compõem esse falar, pessoas que afirmam não produzir o " $r$ caipira" (variante retroflexa), mas o autor desconsidera essas afirmações, pois acredita que $(-r)$ de outras naturezas ocorrem apenas "num diálogo tenso ou formal. Perdida a formalidade, $\underline{\text { o }}$ retroflexo retorna" (grifo nosso) (ZÁGARI, 1996:17).

Em seu trabalho sobre o retroflexo na cidade sul-mineira de Lavras, Aguilera e Silva (2011) investigaram a "vitalidade ou debilidade" dessa variante dentro da comunidade de fala estudada, a partir de dados coletados em momentos históricos distintos. Dados registrados no Esboço de um atlas linguístico de Minas Gerais (EALMG) (RIBEIRO et al., 1977) foram comparados a dados coletados pelo AliB (Atlas Linguístico do Brasil), que advêm de quatro entrevistas realizadas junto a informantes lavrenses divididos segundo sexo, duas faixas etárias e com nível Fundamental de escolaridade.

A respeito dos dados referentes a Lavras advindos do EALMG afirmam as autoras:

(...) a variante retroflexa foi registrada nas cartas 2 (arco-íris) e 3 (arco da velha). A carta 8 (mormaço) traz o /r/ vibrante velar sonoro e a de $\mathrm{n}^{\circ} 29$ (salto mortal) o mesmo informante realiza o rótico como vibrante alveolar sonoro. (AGUILERA; SILVA, 2011:127). 
Segundo dados do $\mathrm{ALiB}$, o retroflexo ocorre em quatro mesorregiões mineiras: (a) Campo das Vertentes; (b) Oeste de Minas; (c) Sul e Sudoeste de Minas e (d) Triângulo Mineiro e Alto Paranaíba. Um dos pontos que se localiza em meio a essas mesorregiões é a cidade sul-mineira de Lavras.

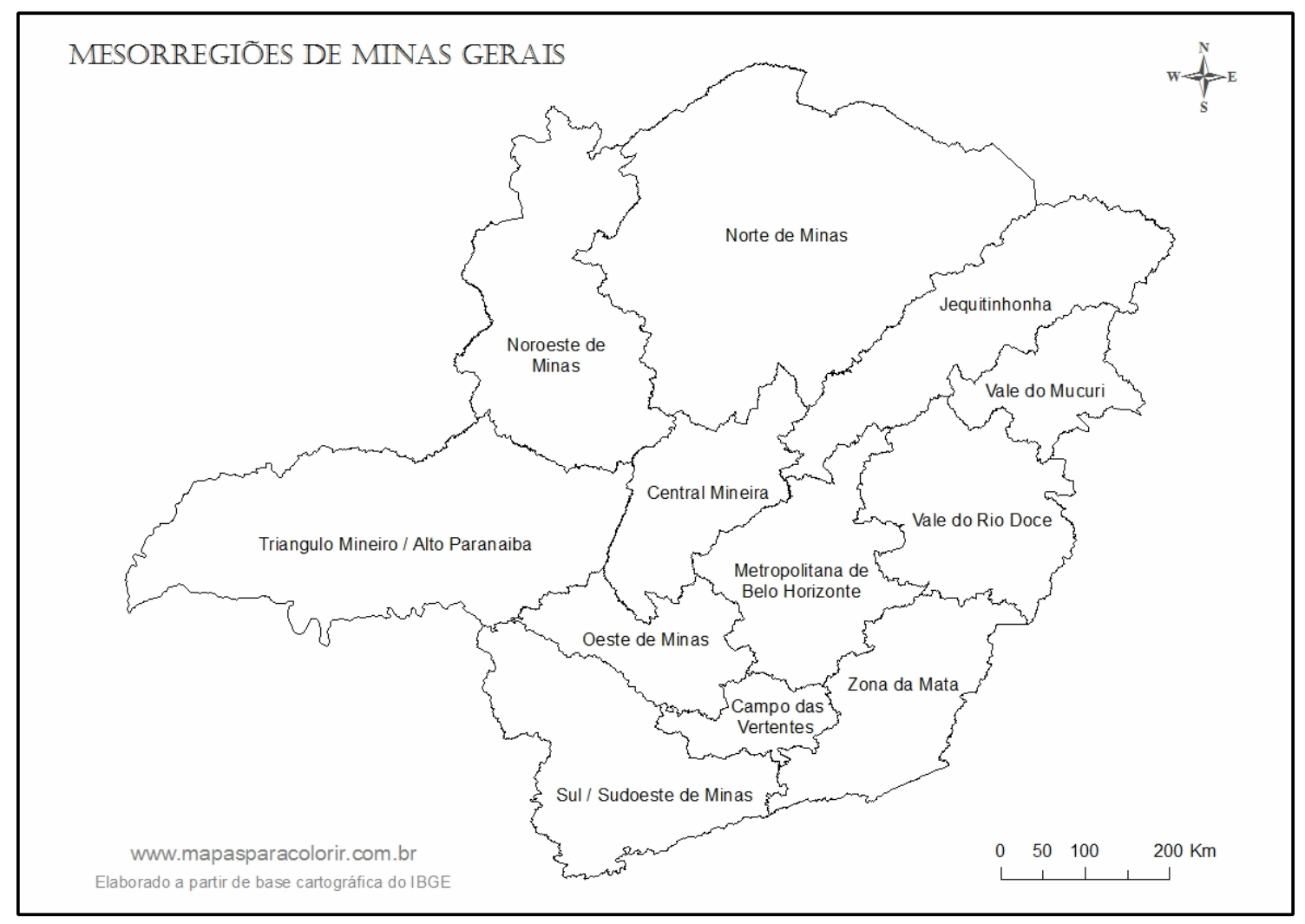

Figura 18 - Mesorregiões do Estado de Minas Gerais ${ }^{29}$

Ainda em relação aos dados coletados pelo AliB, foi constatada uma porcentagem de realização de (-r) como retroflexo de $46 \%$, enquanto os outros $54 \%$ se compôs de realizações fricativas glotais.

A afirmação presente em Zágari (1996) a respeito da existência de outros (-r) que não somente o retroflexo na região do sul de Minas Gerais abre caminhos para investigações do tipo empreendidas por Bieler (2012), Lourdes (2011) e Aguilera; Silva (2011) e fornece indícios para a existência de relações sociais complexas subjacentes ao uso de (-r) nessa região do estado.

29 Disponivel em: http://www.mapasparacolorir.com.br/mapa/estado/mg/estadominas-gerais-mesorregioes-nomes.png. Acesso em 08 de Junho de 2015. 


\section{1. (-r) na Carta 2 do EALMG}

A fim de ilustrar a existência de outras variantes de (-r) na região do "falar apaulistado" (ZÁGARI, 1996), considera-se a Carta 2 do Esboço de um Atlas Linguístico de Minas Gerais.

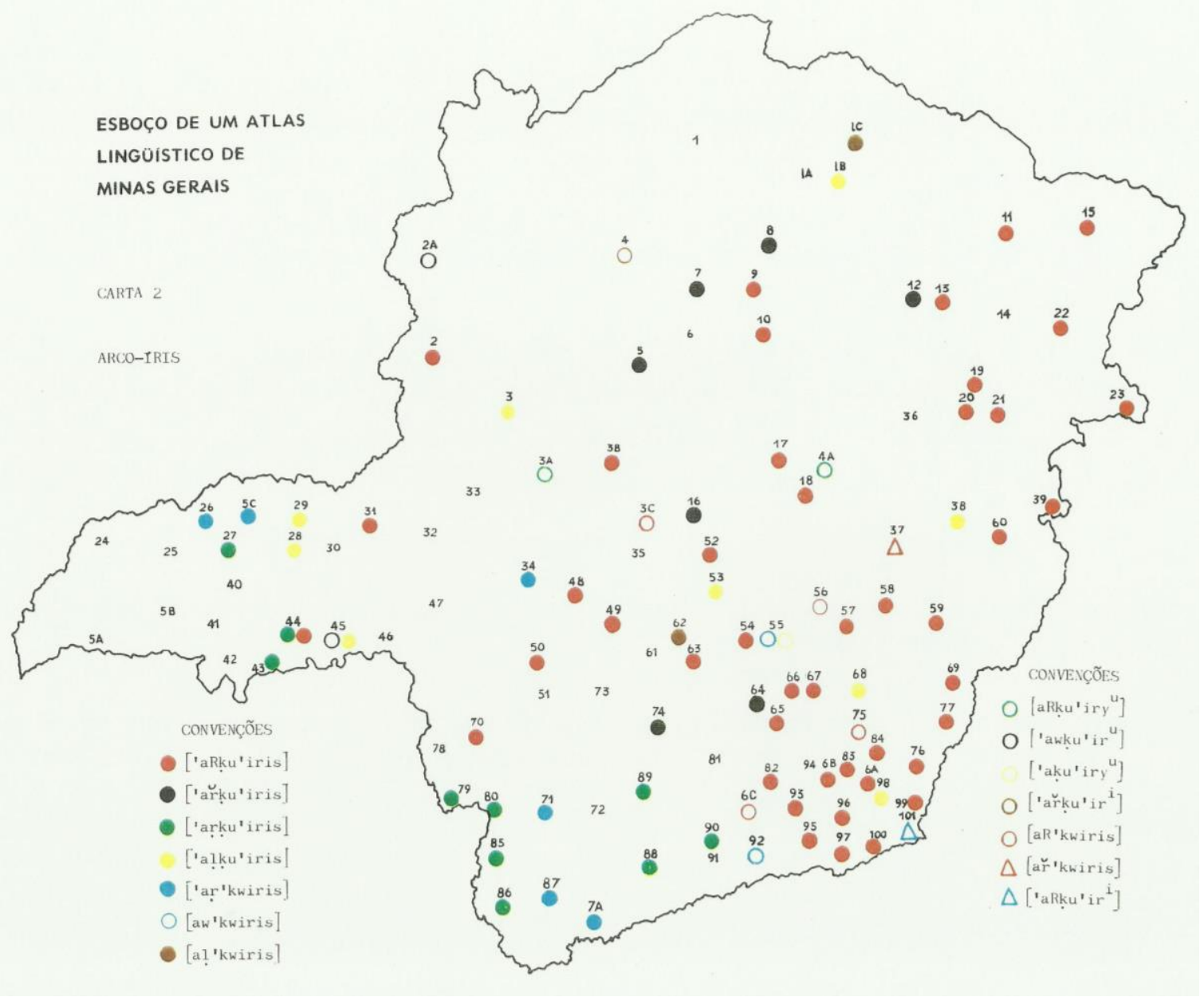

Figura 19: Carta 2 - ocorrência do vocábulo "arco-íris"

Essa carta traz o vocábulo "arco-íris", em suas diversas possibilidades de realização fonética, como reposta dada à questão: "Costuma, às vezes, após a chuva vir logo o sol e, então, aparecem no céu umas faixas coloridas. Dizem mesmo que se um menino passar debaixo vira menina. Como se chama isso?” Não interessa aqui tratar de outros vocábulos que possam ser igualmente fornecidos como resposta para a questão acima, pois o objeto deste trabalho é a realização de $(-\mathrm{r})$, ou seja, o rótico presente no vocábulo arco.

Catorze localidades compõem o que RIBEIRO et al. (1977) chamam de Sul de Minas Gerais. São elas: Itajubá; Passos; Alfenas; Varginha; São 
Sebastião do Paraíso; Guaxupé; Muzambinho; Poços de Caldas; Ouro Fino; Pouso Alegre; Caxambu; Lavras; Andrelândia e Liberdade.

Tabela 4: Vocábulo "arco-íris" no Sul de Minas Gerais

\begin{tabular}{ccc}
\hline Ponto & Município & (-r) em "arco-íris" \\
\hline $7 A$ & Itajubá & ['ar 'kwiris] \\
\hline $\mathbf{7 0}$ & Passos & ['aRku 'iris] \\
\hline 71 & Alfenas & ['ar 'kwiris] \\
\hline 72 & Varginha & - \\
\hline 78 & São Sebastião do Paraíso & - \\
\hline$\underline{79}$ & $\underline{\text { Guaxupé }}$ & ['arku 'iris] \\
\hline$\underline{80}$ & $\underline{\text { Muzambinho }}$ & ['arku 'iris] \\
\hline$\underline{85}$ & $\underline{\text { Poços de Caldas }}$ & ['arku 'iris] \\
\hline$\underline{86}$ & $\underline{\text { Ouro Fino }}$ & ['arku 'iris] \\
\hline 87 & Pouso Alegre & ['ar 'kwiris] \\
\hline$\underline{88}$ & $\underline{\text { Caxambu }}$ & ['arku 'iris] \\
\hline$\underline{89}$ & $\underline{\text { Lavras }}$ & ['arku 'iris] \\
\hline$\underline{90}$ & $\underline{\text { Andrelândia }}$ & ['arku 'iris] \\
\hline 91 & Liberdade & \\
\hline
\end{tabular}

As transcrições fonéticas na Tabela 4 seguem os critérios de Ribeiro et al. (1977), de acordo com os quais:

- $[r]$ representa a vibrante retroflexa sonora;

- $[\mathrm{R}]$ representa a vibrante velar sonora.

$\mathrm{Na}$ Tabela 4, as localidades que revelaram uma mesma realização para o vocábulo "arco-íris" estão marcadas igualmente. São basicamente duas possibilidades de realização desse vocábulo: a forma que se dá entre as localidades destacadas em itálico e a forma que se dá entre as localidades sublinhadas.

Os pontos 72, 78 e 91 (Varginha, São Sebastião do Paraíso e Liberdade respectivamente) não tiveram formas registradas desse vocábulo, provavelmente porque a questão correspondente a ele não foi respondida pelo informante. Já no ponto 70, a cidade de Passos (em negrito na Tabela 4), o vocábulo foi realizado de forma diferente das demais cidades.

Se para os pontos $7 A, 71,79,80,85,86,87,88,89$ e 90, o (-r) foi produzido como vibrante retroflexa sonora, no ponto 70 , foi produzido como uma vibrante velar sonora, um tipo de (-r) não prototípico na região e que 
parece indicar, ao lado de Itanhandu, Lavras (AGUILERA; SILVA, 2011) e Pato de Minas (LOURDES, 2011), a existência de outros tipos de (-r) nessa região.

$\mathrm{Na}$ Figura 20 a seguir, a parte hachurada no mapa, que abrange sul e triângulo mineiro, é assim marcada a fim de identificar a presença hegemônica do (-r) retroflexo na região. A região pontilhada, por sua vez, também marca a presença do retroflexo, mas indica a sua convivência com outras variantes de $(-\mathrm{r})$.

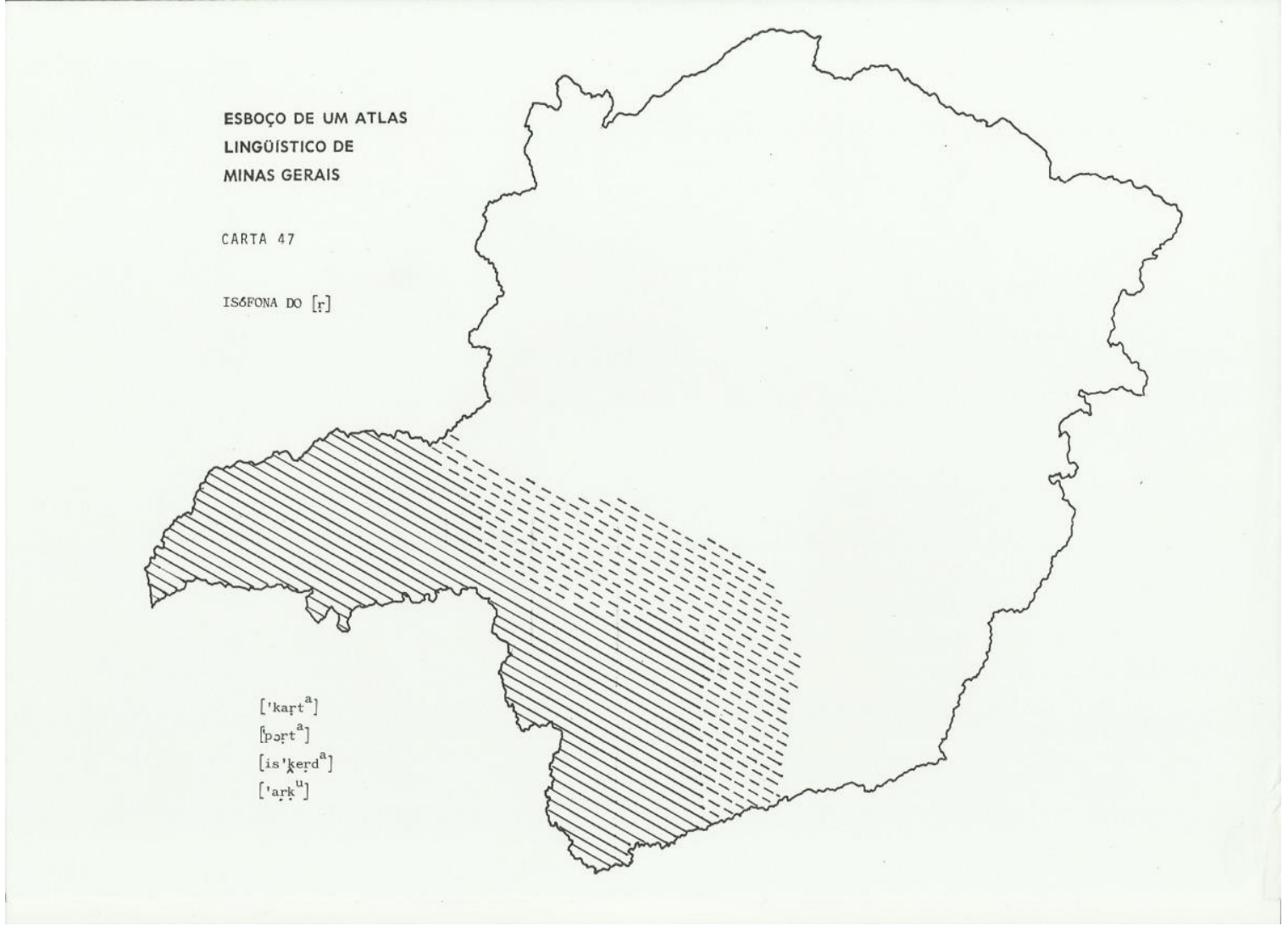

Figura 20: Carta 47 - região isófona da variante retroflexa

Itanhandu localiza-se na parte hachurada do mapa, em uma região bastante próxima à área que aparece pontilhada. $\mathrm{O}$ objetivo aqui é problematizar a divisão proposta por Ribeiro et al. (1977), apesar de localizada em uma região em que se verificou apenas a presença do retroflexo, tepes e fricativos fazem-se também presentes na cidade sob investigação.

A fim de investigar os fatores correlacionados ao uso das diferentes variantes de (-r) em Itanhandu, o Capitulo 4 a seguir apresenta as variáveis independentes consideradas nas análises quantitativas. Primeiro serão apresentados os grupos de fatores estratificadores da amostra, ou seja, 
aqueles que foram usados como critérios para a seleção dos informantes que formaram a amostra de fala itanhanduense, e depois serão apresentados os demais grupos de fatores analisados. 


\section{Capítulo 4: Hipóteses de correlação e grupos de fatores}

As 36 entrevistas sociolinguísticas descritas no Capítulo 2 totalizam mais de 36 horas de gravação, que foram ouvidas no intuito de marcar as ocorrências de $(-r)$ como retroflexos $(R)$, tepes $(T)$ e fricativos $(H)$.

Foram estabelecidas treze variáveis sociais e linguísticas como hipóteses de correlações com a variação na pronúncia de (-r), tanto para a análise de retroflexos versus tepes e fricativos, quanto para a análise de retroflexos "fortes" versus retroflexos "fracos".

1. Identificação do Informante com a Cidade

2. Sexo/ Gênero do Informante

3. Faixa Etária do Informante

4. Contexto Fônico Precedente ao (-r)

5. Contexto Fônico Seguinte ao (-r)

6. Posição da Sílaba com (-r) em Relação à Tônica

7. Posição do (-r) na Palavra

8. Classe Morfológica da Palavra com (-r)

9. Frequência da Palavra com (-r)

10. Parentes Fora de Itanhandu

$$
\text { 11. Estilo }
$$

13. Tempo Fora de Itanhandu

Quadro 4: Grupos de Fatores incluídos na análise

1. Variáveis independentes estratificadoras da amostra

Os grupos de fatores estratificadores da amostra representam, também eles, hipóteses a serem verificadas em relação ao caso de variação em foco. Tais hipóteses são apresentadas a seguir. 


\subsection{Identificação com a Cidade 30}

Retomando o que foi dito no Capítulo 1, é possivel afirmar que, em Itanhandu, há diferenciações sociais baseadas no modo como as pessoas se relacionam com o "lugar" (em sentido sociolinguístico; JOHNSTONE, 2004). Os itanhanduenses declaram-se, nem sempre de maneira bastante assertiva, participantes de um dos dois subgrupos sociais existentes no município: aquele é que composto por pessoas que não desejam se mudar da cidade, ou que, tendo saído de Itanhandu, desejam voltar a viver lá; outro formado por pessoas que desejam se mudar de Itanhandu, ou que, uma vez já morando fora, não desejam retornar à cidade.

Para alguns informantes, querer sair da cidade, ou não querer retornar a ela, não é negar o fato de que se é itanhanduense ou de que se gosta de lá. Por outro lado, em certos casos, sair da cidade é sinônimo de ir em busca de oportunidades financeiras ou educacionais enquanto que retornar a ela passa a significar limitação espacial, social e econômica. Os excertos a seguir exemplificam isso.

D1: e você gosta de morar aqui em Itanhandu?

$\mathrm{S} 1$ : gosto mas queria ir embora

D1: se tivesse chance você ia embora?

S1: ia... ia embora

D1: por quê? que que você vê aqui que te faz querer ir embora?...

S1: ah porque aqui o [hes.] aqui é gostoso vim morar mas o [hes.] custo de vida é muito caro

D1: é?...

S1: e tudo que você faz é só um salário só um salário... e lá fora não...

D1: uhum...

S1: lá fora é mais mas tem que te(r) estudo né? senão...

D1: é complicado né?

S1: é...

D1: mas você acha que aqui [hes.] a qualidade de vida é boa mas não compensa

S1: não compensa...

D1: que que você acha que seria melhor assim? que oportunidades você acha que você teria fora daqui?...

S1: nossa! ia ter nossa! [risos] ia ter muita opor/ nossa muita oportunidade... as/ comprar as coisa né?... e aqui é dificil... só um salário

D1: você acha que emprego [hes.] você ia conseguir emprego melhor?

30 Inicialmente, vislumbrou-se a divisão dos itanhanduenses em três grupos de acordo com sua maior, menor ou intermediária identificação com a cidade. Por esse motivo, esse grupo de fatores havia recebido o nome de "Graus de Identificação com a Cidade". Entretanto, tal divisão foi alterada (cf. Capítulo 2), passando os itanhanduenses a serem divididos em apenas dois grupos. Sendo assim, tal grupo de fatores passou a se chamar "Identificação com a cidade". 
S1: é... mas tem que es/ mas tem que ter o estudo também né? (F2B_regina)

D1: e [hes.] tem outra cidade que você gostaria de morar?... que você acha que você teria melhores condições?...

S1: olha eu não parei para pensar isso não eu acho que [hes.] sei lá

D1: que São Paulo seria sei lá se você tivesse uma boa opção de emprego você iria para São Paulo?

S1: iria sim

D1: iria... tem muitas cidades dessa regi/ da região aqui que estão se desenvolvendo bastante né? por exemplo São Lourenço

S1: \{está crescendo\}

D1: \{uma cidade\} que está crescendo pra caramba se você tivesse oportunidade de emprego em São Lourenço por exemplo você iria?...

S1: bom iria

D1: iria?

S1: iria... São Lourenço é cidade bonita grande (da região) (M1B_ricardo)

D1: você foi para lá... você foi para lá para [hes.] por causa de emprego?

$\mathrm{S} 1:$ é isso exatamente por causa de emprego

D1: ah tá...

S1: né? aí eu fui para trabalhar porque aqui você sabe que as condições é mais difíceis

D1: é

S1: né?

D1: uhum

S1: então o pessoal não dava muita oportunidade

D1: uhum

S1: ainda mais quando se é pobre é pior ainda

D1: uhum

$\mathrm{S} 1:$ você não tem aquele nome né?

D1: é

S1: então fica mais difícil... então eu fui para lá para isso para trabalhar (...)

D1: para trabalhar

S1: para trabalhar

D1: e voltou para cá

S1: por causa da minha mãe

D1: uhum

S1: mas eu tenho casa lá [hes.]

D1: você tem vontade de voltar para lá?...

S1: olha eu tenho vontade sim de voltar porque eu gosto de São José... mas [hes.]... hoje se você me perguntar assim [hes.] "hoje você quer voltar?"... eu tenho um monte de coisa que me prende aqui agora

D1: uhum (F3B_vânia)

A correlação entre esse grupo de fatores e a variável (-r) (retroflexos versus tepes e fricativos), pode-se dar de seguinte maneira:

- Fricativos e tepes são mais frequentes entre os itanhanduenses que não se identificam (ou se identificam menos) com Itanhandu. Neste caso, 
essas pronúncias poderiam ser uma maneira de evidenciar um distanciamento desses informantes em relação à cidade.

- Diferentemente, fricativos e tepes seriam relativamente menos frequentes entre os itanhanduenses que, sim, se identificam com a cidade, uma vez que haveria por parte deles uma tendência de uso da variável que marca a "identidade itanhanduense".

A hipótese não será confirmada se não se verificar diferenciação entre os dois subgrupos, no que toca à ocorrência de fricativos e tepes em sua fala. Poderia ser o caso, então, de que essas pronúncias funcionem como uma marca ou um índice (ECKERT, 2008, SILVERSTEIN, 2003) que caracterizaria toda cidade (talvez em relação a outras cidades do Sul de Minas) e não apenas um grupo de seus falantes.

Após reportar os resultados da análise quantitativa retroflexo versus tepes/fricativos, analisa-se, no Capítulo 6, a fala dos indivíduos também à luz dos grupos de identificação com cidade, entre outros elementos linguísticos e sociais considerados. Tal análise se justifica na medida em que análises no nível do individuo ajudam a explicar e aprofundam resultados obtidos estatisticamente (apresentados no Capítulo 5) e também porque permitem apreender aspectos da variação intrafalante (o que, consequentemente, permite uma sistematização do uso linguístico da comunidade de fala no todo e em seus elementos particularizantes).

Já em relação aos "graus" de retroflexão (forte e fraco), a hipótese a ser testada é a seguinte:

- retroflexos fracos seriam favorecidos entre os itanhanduenses que se identificam menos com a cidade e com o modo de vida de seus habitantes. Diferentemente, tal variante seria desfavorecida entre os informantes que se identificam com Itanhandu. Tal expectativa baseiase no fato de que os retroflexos fortes são a variante mais prototípica na cidade e que, assim, tenderia a ser mais empregada por aqueles que desejam evidenciar uma maior aproximação (inclusive linguística) com a realidade de Itanhandu. 


\title{
1.2. Sexo/gênero
}

Essa variável tem se mostrado relevante nos estudos sociolinguísticos, tanto quando se trata de fenômenos de variação estável, quanto de casos de mudança linguística.

Em casos de variação estável, nos quais não há evidências de que uma variante possa estar se tornando mais frequentemente utilizada do que outra, as mulheres têm mostrado, segundo Labov (2001), preferência pelo emprego das formas linguísticas de maior prestígio social. Já nos casos de mudança linguística, em que uma das formas vai passando a ser mais usada, as mulheres tendem a liderar a propagação do emprego da forma não padrão. A respeito disso, sumariza Chambers (2003),

\begin{abstract}
Este resultado provou-se forte em muitos contextos socioculturais de tal modo que levou os sociolinguistas à conclusão geral de que "mulheres são mais sensiveis do que os homens aos padrões de prestígio" (Labov, 1972) e que "mulheres são claramente mais preocupadas com a pressão exercida pelas normas locais e afirmam seu status dentro da estrutura social" (Romaine, 1978). Holmes (1997) diz que "a linguagem é um importante recurso pelo qual mulheres afirmam sua autoridade e posição, uma forma de capital simbólico para elas". (CHAMBERS, 2003: 4) ${ }^{31}$
\end{abstract}

É comum nos estudos sociolinguísticos cruzar a variável sexo/gênero com outras variáveis de natureza social, como a faixa etária do informante (CALLOU; MORAES; LEITE, 1996; GOMES DA SILVA, 2014, OUSHIRO, 2015, por exemplo). Muitas vezes, a realização de uma forma linguística está não só correlacionada ao fato do informante ser homem ou mulher, mas também ao fato de ser homem mais jovem, mulher mais velha, e assim por diante.

No caso da variação na pronúncia de (-r) e de graus de retroflexão por itanhanduenses, a hipótese geral acerca do sexo/gênero do informante pode ser assim formulada:

\footnotetext{
31 Texto original: This result has proven so robust in so many sociocultural settings as to lead sociolinguistics to the general conclusion that "women are more sensitive than men to the prestige pattern" (Labov, 1972) and that "females are clearly more concerned with the pressure exerted by local norms and asserting their status within the social structure" (Romaine, 1978). Holmes (1997) says, "language is an important means by which women assert their authority and position, a form of symbolic capital for women". (CHAMBERS, 2003:4).
} 
- As mulheres tenderiam a liderar a mudança, favorecendo a produção das formas inovadoras, ou seja, as formas não prototípicas de (-r) em Itanhandu (fricativos e tepes) e dos retroflexos fracos.

- As mulheres tenderiam a empregar mais fricativos e tepes em caso de variação estável, no momento em que essas formas adquirem certo prestígio na cidade.

- Ainda no caso de variação estável, as mulheres não favoreceriam as pronúncias tepe, fricativa e nem retroflexo fraco por ser a retroflexa a pronúncia "padrão" da comunidade.

\subsection{Faixa Etária}

A faixa etária do informante tem sido de grande importância nos estudos sociolinguísticos por conta do construto teórico do "tempo aparente" (LABOV, 2001), de acordo com o qual se pode vislumbrar se um caso de variação é estável ou se se trata de mudança em progresso.

Uma variação é considerada estável quando um fenômeno linguístico observado a certa taxa na primeira faixa etária é igualmente encontrado em taxas próximas na segunda ou terceira faixas etárias ou quando uma variante linguística possui a mesma frequência de ocorrência entre a primeira e a terceira faixas, mas difere no que diz respeito à segunda.

Tem-se mudança em progresso quando um fenômeno linguístico passa a ser sistematicamente mais (ou menos) usado quando se parte da primeira faixa etária, passa-se pela segunda e chega-se na terceira.

Em seus estudos sobre Martha's Vineyard (1963) e sobre Nova York (1966), Labov introduziu uma metodologia que tornou possivel o estudo sincrônico da mudança. Em vez de trabalhar com amostras linguísticas de épocas diferentes da história de uma comunidade de fala ("tempo real”), coleta-se uma amostra que contemple informantes de diferentes faixas etárias - o que permite ter um indicativo de mudanças linguísticas em "tempo aparente".

Esse construto se baseia na hipótese clássica que considera que o processo de aquisição de linguagem se encerra por volta dos quinze anos. Dessa forma, a língua que utilizamos ao longo de nossas vidas teria sido adquirida até essa idade. Por exemplo, um indivíduo de 40 anos de idade, no 
ano 2000, fala como já falava aos 15 anos, ou seja, no ano de 1975. Com uma amostra que inclui três faixas etárias, têm-se, então, em tempo aparente, dados de três épocas diferentes (apesar de coletados num mesmo recorte sincrônico).

Assim, há indício de mudança em progresso quando os informantes da primeira faixa etária empregam mais frequentemente formas linguísticas inovadoras relativamente à segunda e, esta, relativamente à terceira. Para o presente estudo, são vários os resultados possiveis:

Num caso de mudança,

- Tepes, fricativos e retroflexos fracos tenderiam a ser mais frequentes entre os mais jovens da amostra e relativamente menos frequentes entre aqueles da segunda e menos frequentes ainda entre os informantes da terceira faixa etária.

Caso haja variação estável,

- Não haveria diferenciação entre os falantes das três faixas, e tepes, fricativos e (-r) fracos seriam empregados nas três com tendências semelhantes.

- Os mais jovens e os mais velhos usariam mais frequentemente tepes, fricativos e retroflexos fracos em oposição aos de idade intermediária, que desfavoreceriam tais variantes, uma vez que, inseridos no mercado de trabalho, sofrem a ação do mercado linguístico (BOURDIEU, 1998 apud MORATO; BENTES, 2002), ou seja, tenderiam a empregar o retroflexo forte por ser a variante padrão dentro da comunidade.

2. Demais variáveis independentes

2.1. Contexto Fônico Precedente e Seguinte ao (-r)

O processo fonológico que interessa para a consideração dos grupos de fatores Contexto Fônico Precedente e Contexto Fônico Seguinte ao (-r) é o processo de assimilação. De modo geral, pode-se definir assimilação como um processo fonológico em que um som adquire traços de outros sons que o rodeiam (SOUZA; SANTOS, 2007). Ela pode ser total, se o segmento torna-se igual ao que o precede ou sucede, ou parcial, se houver assimilação apenas do ponto de articulação, modo de articulação ou vozeamento (no caso das 
consoantes); altura do corpo da língua ou posição da língua (no caso das vogais).

O processo fonológico de assimilação se divide ainda em "progressivo" ou "regressivo". Quando há a propagação de determinada característica no sentido do começo para o fim da palavra trata-se de uma assimilação "progressiva".

Da mesma forma, tem-se "assimilação regressiva" quando a propagação da característica fonético-fonológica se dá do fim para o início da palavra, ou seja, quando um elemento linguístico assimila características de uma forma que o sucede. Por exemplo, considerando-se a palavra “carga”, em que o (-r) fosse realizado como variante fricativa velar, poderia aventar-se a hipótese de que tal fato se devesse a uma assimilação regressiva de traços, ou seja, o rótico teria assimilado o traço velar da consoante /g/ que o sucede.

Esse grupo de fatores é sempre considerado quando se está realizando análise de variáveis fonético-fonológicas (CALLOU; MORAES; LEITE, 2002; BRANDÃO, 2009; GRECIO, 2012; OUSHIRO, 2015). A inclusão recorrente deste grupo de fatores evidencia sua grande importância nos estudos sociolinguísticos, sobretudo pela atuação do processo linguístico da assimilação de traços, apresentado acima.

O grupo de fatores Contexto Fônico Precedente ao (-r) é formado por todas as vogais orais do PB. Já o grupo de fatores Contexto Fônico Seguinte ao $(-r)$ é composto por todas as consoantes, além de "pausa".

\subsection{Posição da sílaba com (-r) em relação à tônica}

A variante de (-r) pode estar em sílabas distintas dentro do vocábulo:

- Duas ou mais posições antes da sílaba tônica;

- Uma posição antes da sílaba tônica;

- Na própria sílaba tônica;

- Na sílaba seguinte à sílaba tônica.

Em trabalho realizado sobre a pronúncia do (-r) na cidade de São Paulo, Oushiro (2015) verificou que o retroflexo, forma menos frequente na cidade (cerca de 30\% versus 70\% da variante tepe), é levemente favorecido em sílabas tônicas (peso .55). A respeito desse resultado e de um possível continuum de enfraquecimento na pronúncia do (-r) no PB, a autora afirma: 
Embora [r] seja um segmento [-anterior] do que [r], o fato de que é favorecido em segmentos que tendem a ter proeminência prosódica na sentença (sílabas tônicas e palavras de conteúdo, sobretudo verbos) indica que se trata antes de um processo de fortificação do que de lenição. (OUSHIRO, 2015: 104).

\subsection{Posição do (-r) na palavra}

Esse grupo de fatores diz respeito à hipótese de que a pronúncia do (-r) e dos diferentes graus de retroflexão em Itanhandu varia de acordo com sua posição no meio ou no final da palavra.

Callou et al. (2002) afirmam que “(...) é preciso distinguir a posição interna e a posição externa do vocábulo, não só no que diz respeito à distribuição das variantes, mas também em relação aos fatores favorecedores dos processos ocorrentes nessas posições (...)".

Em trabalho sobre o (-r) em São Paulo, Oushiro e Mendes (2013 [2011]) verificaram que a posição final favorece, ainda que levemente, a pronúncia do retroflexo, que é a forma menos comum em tal cidade.

De modo semelhante, interessa verificar se a pronúncia variável de $(-r)$ correlaciona-se à sua posição na palavra, em Itanhandu.

Especificamente com relação aos graus de retroflexão, pode-se comparar o (-r) fraco com casos de apagamento de (-r). Em termos fonéticos, apagamentos e (-r) fracos são mais próximos entre si do que apagamentos e (-r) fortes. Numerosos estudos (p.ex., VOTRE, 1978 apud REIS; DIAS, 2006; CALLOU, 1979 apud REIS; DIAS, 2006; MOLLICA, 1997) verificaram que o apagamento do rótico ocorre, principalmente, em final de palavra.

\subsection{Classe Morfológica da palavra com (-r)}

Os fatores que integram esse grupo são: substantivo, adjetivo, numeral, verbo, preposição, conjunção e advérbio.

No mesmo estudo citado acima, Oushiro e Mendes (2013 [2011]) verificaram que o retroflexo era levemente favorecido entre verbos e advérbios (.55) e fortemente desfavorecido (.39) entre conjunções e preposições. Ou seja, a forma retroflexa do rótico era favorecida entre "palavras de conteúdo" e desfavorecida em palavras com função mais gramatical.

Especificamente no que diz respeito aos graus de retroflexão, a semelhança fonética entre apagamentos e (-r) fracos e os resultados obtidos 
por alguns estudos (VOTRE, 1978; CALLOU, 1979; MOLLICA, 1997 apud REIS; DIAS, 2006) acerca do favorecimento do apagamento quando o segmento rótico encontra-se na classe morfológica dos verbos, permite aventar a seguinte hipótese:

- A ocorrência de retroflexo fraco em Itanhandu estaria correlacionado à classe morfológica dos verbos, à semelhança do que ocorre com os dados de apagamento.

Outra opção de análise para os graus de retroflexão em Itanhandu é pensar em termos de proeminência prosódica na sentença, ou seja, de um lado têm-se os elementos de maior proeminência prosódica (substantivos e verbos) e de outro se têm elementos de menor proeminência (adjetivos, numerais, preposições, conjunções e advérbios). Assim, pode-se hipotetizar que os elementos de maior proeminência tenderiam a preservar o $(-r)$ retroflexo como forte, ao passo que os elementos de menor destaque tenderiam a enfraquecer o (-r) retroflexo.

\subsection{Frequência do item lexical com (-r)}

A inclusão desse grupo de fatores na análise se justifica na medida em que, para a Teoria dos Exemplares (PIERREHUMBERT, 2001a; 2012b; BYBEE, 2001), que também entende a lingua como um sistema em uso, a frequência de uso de um item lexical é a força que modela o armazenamento das formas linguísticas na memória.

Dessa maneira, dentro da memória, palavras mais frequentes são encontradas em níveis de ativação mais altos, o que faz com elas sejam facilmente acessadas e utilizadas na produção da fala cotidiana (GOLDINGER, 1996, DAHAN et al., 2001, ABRAMOWICZ, 2007). Por isso, de acordo com Jurafsky el al. (2000), palavras bastante frequentes na lingua tendem a sofrer vários processos linguísticos, como encurtamento da duração de algum segmento ou apagamento de algum elemento, mais do que itens menos frequentes.

Alguns autores, como Pierrehumbert (2001a, 2002b), Bybee; Hopper (2001) e Walker (2012) têm dado destaque à importância da frequência dos itens lexicais nos processos de variação e mudança linguísticas. Esses autores entendem que tais processos são liderados por palavras de alta frequência. 
Buscando testar a proposição de Bybee e Pierrehumbert, Labov (2003) fez um estudo sobre a anteriorização do núcleo dos ditongos posteriores / uw/, /aw/, /ow/ (em palavras como "two", "house" e "home" respectivamente, que são fonemas presentes em várias comunidades de fala dos Estados Unidos). Entretanto, nesse estudo, Labov não verifica uma correlação entre a variação investigada e a frequência de realização das palavras. O fato de a palavra ser mais ou menos frequente parece ser indiferente à mudança sonora analisada.

Diante disso, Dinkin $(2004,2007)$ propõe que o efeito da frequência é restrito a mudanças lenitivas, ou seja, mudanças que envolvem um processo fonológico de enfraquecimento da articulação das consoantes provocando desvozeamento, aspiração ou apagamento desses segmentos linguísticos. Dinkin chama esse fenômeno de Principio de Phillips: palavras frequentes lideram mudanças sonoras de lenição, mas não mudanças sonoras no geral. Esse princípio poderia, por exemplo, ser generalizado para os casos de apagamento de t/d no inglês, que foram classificados como mudança sonora em progresso por Bybee; Hopper (2001).

Os dados que compõem este grupo de fatores no presente estudo são divididos em três categorias: (a) palavras que aparecem até 39 vezes no corpus; (b) palavras que se realizam entre 40 e 180 vezes e (c) palavras que ocorrem mais de 180 vezes no corpus. O estabelecimento dos grupos de frequência, bem como do limite da quantidade de vezes de cada vocábulo que seria classificado em cada grupo, objetivou formar três grupos de frequência com quantidades de dados equilibrados e comparáveis entre si. Assim, como há muitas palavras pouco frequentes e poucas palavras muito frequentes $o$ número de vezes que cada vocábulo é usado e que determinou o limite de cada fator dentro desse grupo é bastante espaçado entre si.

\subsection{Parentes fora de Itanhandu}

A inclusão desse grupo de fatores na análise aqui apresentada se deve ao interesse em investigar casos de itanhanduenses que afirmam se identificar com a cidade, seus costumes e habitantes, mas ainda assim produzem casos de variantes de (-r) que não a prototípica retroflexa ou que produzem frequentemente retroflexos fracos, variante menos frequente na cidade, em geral.

Um dos casos que ilustra isso é o da informante Clarice. Em determinado momento da entrevista, ela produz um (-r) fricativo. Investiga-se 
a hipótese de que produções desse tipo estejam correlacionadas ao fato do informante ter parentes morando fora de Itanhandu. Dessa forma, esta categoria de informantes estaria em maior contato com a realidade sociolinguística de outras localidades.

Os informantes, segundo essa variável independente, foram divididos em dois grupos: itanhanduenses que têm pais ou irmãos morando fora da cidade e itanhanduenses que não possuem pais e irmãos fora de Itanhandu. De acordo com a categorização proposta, os itanhanduenses ficaram assim distribuídos:

Tabela 5: Distribuição dos informantes de acordo com o Grupo de Fatores Parentes

Fora

\begin{tabular}{cc}
\hline Possuem Parentes Fora & Não Possuem Parentes Fora \\
\hline M1A_daniel & M1A_manoel \\
M2A_jorge & M1A_rogério \\
M3A_antônio & M2A_guilherme \\
M3A_augusto & M2A_marcos \\
M3A_josué & M1B_mauro \\
M1B_gustavo & M1B_ricardo \\
M2B_andre & M2B_mário \\
M2B_humberto & F1A_leticia \\
M3B_frederico & F1A_raquel \\
M3B_joaquim & F2A_luiza \\
M3B_leonardo & F3A_joana \\
F1A_viviane & F3A_rose \\
F2A_clarice & F2B_lorena \\
F2A_fernanda & F2B_regina \\
F3A_luciana & \\
F1B_cristina & \\
F1B_heloísa & \\
F1B_miranda & \\
F2B_marcela & \\
F3B_lúcia & \\
F3B_rosângela & \\
F3B_vânia & \\
\hline
\end{tabular}

O grau de parentesco considerado para a classificação dos itanhanduenses nesse grupo de fatores foi paterno ou fraterno, ou seja, foram considerados apenas pais e irmãos, já que quase a totalidade dos moradores de Itanhandu tem um tio, primo ou parente mais distante que decidiu construir sua vida fora da cidade.

\subsection{Estilo}

Labov (1966 apud LABOV, 2001) entende estilo como diferentes graus de monitoramento dedicados à fala. Consequentemente, o autor propõe a 
divisão da fala em "Cuidadosa" e "Casual". A primeira caracterizar-se-ia por uma atenção maior do falante em relação ao que está dizendo, enquanto na segunda, haveria um relaxamento maior do falante e ele prestaria menor atenção às formas linguísticas que emprega.

Baseando-se em Labov (2001), as entrevistas sociolinguisticas que formam o corpus itanhanduense foram divididas em quatro tipos de textos: lista de palavras; notícia de jornal; depoimento e entrevista semi-espontânea (também chamada de conversação).

O objetivo dessa divisão, juntamente com a concepção de estilo considerada para esse grupo de fatores, é verificar a existência de correlação entre o emprego variável de (-r) em Itanhandu, bem como dos graus de retroflexão existentes na cidade, e o tipo de texto que está sendo empregado.

Oushiro (2015) verificou diferença significativa entre os estilos textuais empregados e a variável (-r) na cidade de São Paulo. Enquanto conversação, leitura de notícia e leitura de depoimento favoreceram o uso de (-r) retroflexo na capital (.58), a leitura da lista de palavras desfavoreceu fortemente tal variante (.24).

Em Itanhandu, devido à distribuição bastante irregular dos dados entre os estilos textuais, os dados de entrevista são bem mais numerosos do que os dados de leitura de depoimento, notícia e lista de palavras, será realizada uma análise que oponha dados de conversação (entrevista) e dados de leitura. Além disso, tal análise objetiva opor dados de um estilo mais casual (conversação) a dados de estilos mais cuidadosos (leituras).

\subsection{Tópico Tratado}

Esse grupo de fatores é composto de todos os assuntos abarcados pelo informante ao longo de sua entrevista sociolinguística. Tais assuntos são introduzidos pelo documentador e devem ser desenvolvidos pelos entrevistados.

Assim, seguindo a estrutura organizacional das entrevistas, tais tópicos são: cidade (de Itanhandu ou outras consideradas comparativamente a ela); infância, família, trabalho/ocupação, lazer, produção/percepção/avaliação linguística, lista de palavras, leitura de notícia e leitura de depoimento (Anexo I).

Os três últimos elementos dessa lista de palavras não são "tópicos de fato", ou melhor, não são assuntos sobre os quais os informantes podem falar 
livremente, mas sim tarefas que são solicitadas aos entrevistados de modo que cabe a eles apenas executá-las por meio de leitura. Dessa maneira, esses três fatores, apenas a título de classificação, foram analisados qualitativamente em conjunto e com valor de "não se aplica".

Em seu estudo sobre o inglês do Lower East Side em Nova York, Becker (2009) observou que, paralelamente ao avanço na marcação do elemento rótico em posição de coda, o apagamento de tal fonema passou a ser usado por um grupo de residentes brancos a fim de marcar uma identidade ligada ao lugar. A pesquisadora constatou também que o uso da não roticização aumentava quando estes informantes falavam sobre tópicos relacionados ao bairro.

De modo semelhante, ao se investigar tal grupo de fatores intenciona-se verificar se a realização da variante retroflexa versus a realização das variantes tepes e fricativas e a ocorrência de retroflexos fracos versus a ocorrência de retroflexos fortes também se correlaciona aos tópicos dos quais se fala.

\subsection{Tempo Fora de Itanhandu}

Para o estabelecimento dos fatores que compõem esse grupo, foi considerado o tempo de permanência de cada itanhanduense fora de Itanhandu proporcionalmente a sua idade. Dessa forma, o que se obteve foi uma porcentagem que traduz o tempo de permanência fora da cidade sob investigação em relação ao tempo de vida de cada informante.

Esse grupo de fatores compôs-se de 3 categorias: informantes que nunca moraram fora da cidade; que moraram fora até $29 \%$ de suas vidas e informantes que moraram fora da cidade $30 \%$ de suas vidas ou mais. As duas últimas categorias são formadas não só por pessoas residentes em Itanhandu, mas também por aquelas que moram em outras cidades. Esses fatores visam a uma distribuição equilibrada dos informantes.

É importante destacar que, nas análises quantitativas, esse grupo de fatores interage com o grupo de fatores Identificação com a Cidade.

Esses grupos testam hipóteses distintas, conforme já se descreveu, pois pode haver itanhanduenses que, mesmo se identificando bastante com a cidade em que nasceram e cresceram, tenham saído de lá, seja em busca de empregos melhores ou por outros motivos. De modo parecido, pode haver informantes que, mesmo não se identificando com o modo de vida itanhanduense, não tenham tido oportunidade de viver em outras cidades. 
Dentro do grupo de fatores Tempo de permanência fora de Itanhandu, os informantes que nunca saíram da cidade sempre são do grupo de identificação A. De modo semelhante, os informantes que estão há $30 \%$ ou mais de suas vidas fora de Itanhandu são todos do grupo de identificação B. Por esse motivo, esses dois grupos foram inseridos em análises estatísticas distintas.

Além disso, em outra análise, tais grupos de fatores foram cruzados, passando a formar um único e novo grupo de fatores. Tal cruzamento teve como objetivo entender mais profundamente o comportamento da cada fator desses grupos em relação à variação estudada (os resultados e interpretações dessa análise podem ser vistos no Capítulo 5 a seguir).

O Quadro 5 a seguir resume os grupos de fatores, com os fatores que os compõem, considerados nas duas análises quantitativas realizadas e relatadas no capítulo a seguir.

Primeiramente, apresenta-se a análise quantitativa que opõe retroflexos a tepes e fricativos; em seguida, a análise sobre os dois graus de retroflexão.

\begin{tabular}{cl}
\hline \multicolumn{2}{c}{ Grupos de Fatores Estratificadores da Amostra } \\
\hline \multicolumn{1}{c}{ Identificação com a Cidade } & Não quer sair; quer voltar \\
& Quer sair; não quer voltar \\
\hline Sexo/Gênero & Mulheres \\
& Homens \\
\hline Faixa Etária & De 18 a 30 anos \\
& De 31 a 45 anos \\
& 46 anos ou mais \\
\hline Contexto Fônico Precedente ao (-r) & Todas as vogais orais do PB \\
\hline Contexto Fônico Seguinte ao (-r) & Todas as consoantes do PB \\
\hline Posição da sílaba com (-r) em relação à tônica & Uma antes da tônica \\
& Duas ou mais antes da tônica \\
& Na tônica \\
& Uma após a tônica \\
\hline Posição do (-r) na palavra & Meio \\
& Fim \\
\hline Classe Morfológica da palavra com (-r) & Substantivo \\
& Adjetivo \\
& Numeral \\
& Verbo \\
& Preposição \\
& Conjunção \\
& Advérbio \\
\hline Frequência do item lexical com (-r) & Até 39 vezes \\
& De 40 a 180 vezes \\
& Mais de 180 vezes \\
\hline Parentes fora de Itanhandu & Presença de parentes fora \\
& Não presença de parentes fora \\
\hline & Entrevista \\
& Leitura de lista de palavras \\
\hline
\end{tabular}


Leitura de notícia de jornal

Leitura de depoimento

Cidade

Infância

Família

Trabalho

Tópico Tratado

Lazer

Produção/percepção/ avaliação

linguística

Lista de palavras

Leitura de notícia

Leitura de depoimento

Tempo Fora da Cidade

Nunca saiu

Até $29 \%$ fora

$30 \%$ ou mais fora

Quadro 5: Resumo dos grupos de fatores 


\section{Capitulo 5: Análises Quantitativas}

A partir das 36 entrevistas sociolinguísticas coletadas em Itanhandu entre 2010 e 2013, este capítulo traz duas análises quantitativas. A primeira trata dos retroflexos versus tepes e fricativos. A segunda focaliza os retroflexos, em dois graus de retroflexão - fortes (mais longos e intensos) e fracos (mais curtos e menos intensos).

As duas análises visam a testar várias hipóteses (conforme visto no Capítulo 4) sobre as ocorrências dessas pronúncias e descartam, portanto, os casos de apagamento (em que a forma não é realizada pelo falante) e usos metalinguísticos (que geralmente ocorrem quando o informante imita outro falante, normalmente de outra região).

Durante as análises quantitativas, algumas amalgamações de fatores e procedimentos analíticos foram necessários, uma vez que, quando cruzados certos grupos de fatores, revelaram-se algumas células vazias ou com pouca quantidade de dados. Esse fato constitui falta de ortogonalidade entre variáveis (GUY, 2007 [1988]; GUY; ZILLES, 2007): em virtude da distribuição de dados, um grupo de fatores pode não atuar independentemente de outro.

Por exemplo, o grupo Posição do (-r) na palavra (medial ou final) e Contexto Fônico Seguinte ao (-r) não são verdadeiramente independentes entre si, já que "pausa" no contexto fônico seguinte só pode ocorrer quando o (-r) estiver em fim de palavra. Em outro caso de interação, a pouca quantidade de dados por célula leva à interdependência de grupos de fatores, do modo como se observa na Tabela 6 a seguir. 
Tabela 6: Células vazias no cruzamento entre Faixa Etária e Parentes fora de Itanhandu

\begin{tabular}{|c|c|c|c|c|c|c|c|c|c|c|}
\hline & & & & & Faix & Etár & & & & \\
\hline & & & $\begin{array}{c}18 \mathrm{a} \\
30 \\
\text { anos }\end{array}$ & $\%$ & $\begin{array}{c}1 \mathrm{a} \\
45 \\
\text { anos }\end{array}$ & $\%$ & $\begin{array}{c}46 \\
\text { anos } \\
\text { ou } \\
\text { mais }\end{array}$ & $\%$ & Total & $\%$ \\
\hline \multirow{9}{*}{$\begin{array}{l}\text { Parentes } \\
\text { fora de } \\
\text { Itanhadu }\end{array}$} & \multirow{3}{*}{ Possui } & $\begin{array}{c}{[\mathrm{r}] \mathrm{e}} \\
{[\mathrm{h}] \mathrm{ou}[\mathrm{X}]}\end{array}$ & 1 & 0 & 7 & 0 & 35 & 7 & 43 & 1 \\
\hline & & {$[-]$} & 1.974 & $\begin{array}{c}10 \\
0\end{array}$ & 1.926 & $\begin{array}{c}10 \\
0\end{array}$ & 489 & 93 & 4.389 & 99 \\
\hline & & Total & 1.975 & & 1.933 & & 524 & & 4.432 & \\
\hline & \multirow{3}{*}{$\begin{array}{l}\text { Não } \\
\text { possui }\end{array}$} & $\begin{array}{c}{[\mathrm{r}] \mathrm{e}} \\
{[\mathrm{h}] \mathrm{ou}[\mathrm{X}]}\end{array}$ & 327 & 17 & 61 & 4 & 572 & 20 & 960 & 15 \\
\hline & & {$[-1]$} & 1.594 & 83 & 1.663 & 96 & 2.267 & 80 & 5.524 & 85 \\
\hline & & Total & 1.921 & & 1.724 & & 2.839 & & 6.484 & \\
\hline & \multirow[t]{3}{*}{ Total } & $\begin{array}{c}{[\mathrm{r}] \mathrm{e}} \\
{[\mathrm{h}] \mathrm{ou}[\mathrm{X}]}\end{array}$ & 328 & 8 & 68 & 2 & 607 & 18 & 1003 & 9 \\
\hline & & {$[-1]$} & 3.568 & 92 & 3.589 & 98 & 2.756 & 82 & 9.913 & 91 \\
\hline & & Total & 3.896 & & 3.657 & & 3.363 & & 10.916 & \\
\hline
\end{tabular}

A Tabela 6 acima mostra que não é "perfeita" a ortogonalidade entre os grupos de fatores Faixa Etária e Parentes Fora de Itanhandu: há pouca quantidade de dados de tepes e fricativos entre informantes da primeira e da segunda faixa etária que possuem parentes fora de Itanhandu.

\section{Reorganização dos Grupos de Fatores}

Com o GoldVarbX, versão do pacote VARBRUL utilizada nas análises quantitativas deste trabalho, o modelo estatístico não funciona no seu melhor quando o cruzamento entre fatores de diferentes grupos resulta em células vazias (GUY, 2007 [1988]).

Por esse motivo, após realizar cruzamentos entre os diversos grupos de fatores, alguns deles foram reorganizados, através de amalgamações, conforme resume o Quadro 6.

\begin{tabular}{|c|c|c|}
\hline Sexo/ Gênero & \multicolumn{2}{|l|}{$\begin{array}{l}\text { Homens } \\
\text { Mulheres }\end{array}$} \\
\hline Faixa Etária & \multicolumn{2}{|c|}{18 a 30 anos } \\
\hline & \multicolumn{2}{|c|}{31 a 45 anos } \\
\hline & \multicolumn{2}{|c|}{46 anos ou mais } \\
\hline Identificação com a Cidade & \multicolumn{2}{|c|}{$\begin{array}{l}\text { Não querem sair ou querem voltar } \\
\text { Querem sair ou não querem voltar }\end{array}$} \\
\hline \multirow[t]{3}{*}{ Contexto Fônico Precedente ao $(-r)^{32}$} & $\begin{array}{l}\text { Vogais } \\
\text { anteriores }\end{array}$ & $\begin{array}{l}\text { Vogais altas e médias- } \\
\text { altas }\end{array}$ \\
\hline & $\begin{array}{l}\text { Vogal } \\
\text { central }\end{array}$ & \multirow[t]{2}{*}{$\begin{array}{l}\text { Vogais baixas e médias- } \\
\text { baixas }\end{array}$} \\
\hline & $\begin{array}{l}\text { Vogais } \\
\text { posteriores }\end{array}$ & \\
\hline
\end{tabular}




\begin{tabular}{|c|c|c|c|}
\hline \multirow[t]{4}{*}{ Contexto Fônico Seguinte ao $(-r)^{32}$} & Velar & Fricativas & Surdas \\
\hline & $\begin{array}{l}\text { Bilabial/ } \\
\text { lábio-dental }\end{array}$ & Oclusivas & Sonoras \\
\hline & $\begin{array}{l}\text { Alveolar/ } \\
\text { pós- } \\
\text { alveolar }\end{array}$ & Nasais & \multirow[t]{2}{*}{ Pausas } \\
\hline & Pausa & Pausas & \\
\hline \multirow{2}{*}{ Tonicidade da Sílaba com $(-\mathrm{r})^{32}$} & \multicolumn{3}{|l|}{ Tônicas } \\
\hline & \multicolumn{3}{|l|}{ Átonas } \\
\hline Posição do (-r) na palavra & \multicolumn{3}{|l|}{$\begin{array}{l}\text { Meio } \\
\text { Fim }\end{array}$} \\
\hline & \multicolumn{3}{|l|}{ Substantivo } \\
\hline & \multicolumn{3}{|l|}{ Verbo } \\
\hline Classe Morfologica da palavra com $(-\mathrm{r})^{32}$ & \multicolumn{3}{|c|}{ Adjetivo e numeral } \\
\hline & \multicolumn{3}{|c|}{ Conjunção, preposição e advérbios } \\
\hline & \multicolumn{3}{|c|}{ Até 39 vezes } \\
\hline Frequência da palavra com (-r) & \multicolumn{3}{|c|}{$\begin{array}{l}\text { De } 40 \text { a } 180 \text { vezes } \\
181 \text { vezes ou mais }\end{array}$} \\
\hline Estilo $^{1}$ & \multicolumn{3}{|c|}{$\begin{array}{l}\text { Leitura de lista de palavras, notícia de } \\
\text { jornal e depoimento }\end{array}$} \\
\hline Tempo fora de Itanhandu & \multicolumn{3}{|c|}{$\begin{array}{l}\text { Nunca saiu de Itanhandu } \\
\text { Ficou (ou ainda está) até } 29 \% \text { de sua } \\
\text { vida fora } \\
\text { Ficou (ou ainda está) } 30 \% \text { ou mais de } \\
\text { sua vida fora }\end{array}$} \\
\hline Tópico Tratado 32 & $\begin{array}{l}\text { Cidade } \\
\text { Opinião } \\
\text { Vida pessoal } \\
\text { Produção e p } \\
\text { Não se aplica }\end{array}$ & ercepção lin & tica \\
\hline Parentes Fora & \multicolumn{3}{|c|}{$\begin{array}{l}\text { Possui } \\
\text { Não possui }\end{array}$} \\
\hline
\end{tabular}

Quadro 6: Reorganização dos grupos de fatores

Os fatores que compõem o grupo Contexto Fônico Precedente ao (-r) foram amalgamados de duas maneiras distintas: (i) pela posição da língua dentro da cavidade oral, ou seja, anterior, posterior e central e (ii) pela altura do corpo da lingua no trato vocal, ou seja, vogais altas e médias-altas em oposição a vogais baixas e médias-baixas. O objetivo aqui é verificar se esses diferentes modos de organizar tal grupo revela correlações com a variável independente.

${ }^{32}$ Os grupos identificados sofreram algum tipo de modificação em seus fatores iniciais. Abaixo, essas alterações serão comentadas. 
No grupo Contexto Fônico Seguinte ao (-r), as consoantes foram organizadas de acordo com: (i) seu vozeamento - consoantes surdas; consoantes sonoras e pausas; (ii) seu modo de articulação - fricativas; oclusivas; nasais e pausa; e (iii) seus pontos de articulação - velar; bilabial e lábio-dental; alveolar e pós-alveolar e pausa.

Quanto à Posição da Sílaba com (-r), inicialmente foram estabelecidos quatro fatores: (-r) na sílaba tônica; (-r) uma sílaba antes da tônica, (-r) duas ou mais sílabas antes da tônica e (-r) após a tônica. Entretanto, a distribuição das ocorrências de $(-r)$ é bastante irregular, tanto quando se trata de retroflexos versus tepes e fricativos, quanto no caso de retroflexos fortes versus fracos. Esse fato, unido à falta de ortogonalidade envolvendo este e outros grupos de fatores, levou à amalgamação dos fatores 1 posição antes da tônica, 2 posições antes da tônica e depois da tônica em um único fator chamado "sílabas átonas". Assim, este grupo opõe a posição tônica da sílaba com (-r) ao conjunto das outras posições possíveis, ou seja, as posições átonas. Dessa maneira, esse grupo de fatores passou a se chamar Tonicidade da Sílaba com (-r).

Em relação ao Estilo, tepes, fricativos e retroflexos fracos (considerados não prototípicos) são muito mais numerosos na conversação em entrevista do que na leitura da lista de palavras, da notícia e do depoimento. Por isso, estes três últimos fatores foram amalgamados, de modo que tal grupo passou a se compor de dois fatores.

O último grupo de fatores a ser comentado é Tópico Tratado. De início, tal grupo estava organizado de acordo com cada um dos tópicos sobre os quais informante e documentador conversaram ao longo da entrevista sociolinguística (Anexo I).

Entretanto, foi necessário reorganizar tais fatores. O primeiro fator refere-se a assuntos relacionados à cidade de Itanhandu e aos comentários que os informantes tecem sobre ela ou sobre outras cidades comparativamente a ela; o segundo traz opiniões dos informantes acerca dos temas que lhes são propostos para conversação, como política na cidade, por exemplo; o terceiro reúne informações sobre a vida pessoal dos informantes, onde nasceu, para onde já viajou etc; outro abarca a parte da entrevista em que os informantes exprimem suas percepções linguísticas acerca de dados que lhes são apresentados, ou ainda quando são requeridos a produzir algo linguístico característico do itanhanduense, carioca, paulistano etc; por fim, 
um último fator é composto pelos dados em que a categorização "Tópico Tratado" não se aplica. Tal fator é formado pelos trechos de leitura que ocorrem ao fim das entrevistas e que, portanto, não são assuntos que podem ser livremente conversados, mas sim atividades requeridas pelo documentador.

A classificação dos dados em "não se aplica" foi interessante qualitativamente, ou seja, esses dados não foram analisados com os outros dados de tópicos abordados pelos informantes, já que não se tratam de tópicos propriamente ditos. Em outras palavras, os dados que compõem o fator "não se aplica" não são analisados quantitativamente, mas são considerados dentro do grupo de fatores Estilo, uma vez que formam os trechos "lidos", um dos fatores que compõe esse último grupo.

Além dessas amalgamações, vale destacar que alguns grupos de fatores foram analisados separadamente em relação a outros: Posição do (-r) na Palavra, Tópico Tratado e Tempo Fora de Itanhandu foram considerados em análises distintas daquelas em que se incluíram os grupos Contexto Fônico Seguinte ao (-r), Estilo e Identificação com a Cidade, respectivamente. ${ }^{33}$ Tal separação fez-se necessária em face das interações entre tais grupos. Posição do (-r) na Palavra, conforme já se comentou anteriormente, interage intrinsecamente com Contexto Fônico Seguinte ao (-r). O mesmo se observa entre Tópico Tratado e Estilo (já que o estilo "mais cuidadoso" é formado pelos trechos de leitura e dentro do Tópico Tratado há um fator composto pelos trechos lidos), bem como entre Tempo Fora de Itanhandu e Identificação com a Cidade, visto que todos os informantes que nunca saíram de Itanhandu classificaram-se como pertencentes ao grupo mais identificado com a cidade (A) e todos que estão $30 \%$ ou mais de suas vidas fora são do grupo que menos se identifica com a cidade (B).

O grupo Parentes Fora de Itanhandu não foi considerado na primeira análise reportada a seguir por sua falta de ortogonalidade com a maioria dos demais grupos de fatores. Entretanto, ele é considerado na segunda análise quantitativa, ou seja, aquela que trata de retroflexos fortes versus fracos.

\footnotetext{
33 Outra estratégia utilizada para eliminar interação é cruzar os grupos de fatores que interagem, a fim de que se forme um único grupo de fatores a partir dos dois anteriores. Tal estratégia foi empregada com os grupos de fatores Tempo Fora de Itanhandu e Identificação com a Cidade, mas não com os demais. Fica para trabalhos posteriores a possibilidade de investigar tal análise alternativa.
} 
2. Tepes e fricativos versus retroflexos

A Tabela 7 mostra novamente a distribuição dos dados de (-r) realizados em Itanhandu:

Tabela 7: Distribuição dos dados de (-r) realizados em Itanhandu

\begin{tabular}{ccc}
\hline Variantes de $(-\mathrm{r})$ & $\mathrm{N}(\mathrm{T}=10.916)$ & $\%$ \\
\hline Retroflexo & 9.913 & 90,8 \\
\hline Fricativo & 917 & 8,4 \\
\hline Tepe & 86 & 0,8 \\
\hline
\end{tabular}

É notável a supremacia numérica da variante fricativa em relação à variante tepe dentro do grupo composto por (-r) não prototípicos em Itanhandu (conforme pôde ser visto na Tabela 7 acima).

Dessa forma, durante a interpretação dos resultados, principalmente no que diz respeito aos grupos de fatores linguísticos, deve-se ter em mente que as tendências observadas referem-se, sobretudo, aos dados de (-r) fricativos mais do que às ocorrências de (-r) tepes.

Como se pode perceber, retroflexos $(90,8 \%$ dos dados) ocorrem aproximadamente 10 vezes mais do que a soma de fricativos $(8,4 \%$ dos dados $)$ e tepes $(0,8 \%$ dos dados $)$.

Apesar dos tepes serem bem menos frequentes do que os fricativos, tais dados não foram excluídos das análises, uma vez que se mostraram tão não prototípicos em Itanhandu quanto a outra variante (não prototípica) considerada.

Assim, tepes e fricativos foram analisados conjuntamente, em oposição aos retroflexos, com a hipótese de que sua ocorrência pode estar correlacionada ao subgrupo de itanhanduenses que revelam uma relação mais distanciada com Itanhandu.

Em outras palavras, as análises visam a entender os mecanismos linguísticos e sociais envolvidos na ocorrência (do conjunto) dessas pronúncias menos frequentes em Itanhandu, uma comunidade de fala do interior sulmineiro, onde há forte predomínio da pronúncia retroflexa para a coda (-r), conforme vimos no Capítulo 1, considerando-se ainda os significados sociais das pronúncias fricativa e tepe, conforme vimos nos capitulos 1,2 e 3 . 
A Tabela 8 traz os grupos de fatores selecionados na análise estatística como estatisticamente significativos para as ocorrências de tepes e fricativos. O único grupo de fatores que não faz parte dessa lista e que, portanto, não integra os resultados é Tonicidade da Sílaba com (-r).

Tabela 8: Grupos de fatores correlacionados à ocorrência de tepes (T) e fricativos $(\mathrm{F})$

\begin{tabular}{cccccc}
\hline \multicolumn{2}{c}{ Grupos de Fatores } & T+F / total & T + F \% & Peso & Range $^{34}$ \\
\hline Faixa Etária & 18 a 30 anos & $328 / 3896$ & 8,4 & .57 & \\
& De 31 a 45 anos & $68 / 3657$ & 1,9 & .21 & 55 \\
& 46 anos ou + & $607 / 3363$ & 18 & .76 & \\
\hline Classe & verbo & $178 / 1644$ & 10,8 & .57 & \\
Morfológica da & adjetivo/numeral & $215 / 2086$ & 10,3 & .54 & \multirow{2}{*}{ Palavra } \\
& substantivo & $430 / 4970$ & 8,7 & .48 & 13 \\
& conjunção/preposiç. & $180 / 2216$ & 8,1 & .44 & \\
\hline Estilo & Leituras & $257 / 2096$ & 12,3 & .58 & 10 \\
& Entrevista & $746 / 8820$ & 8,5 & .48 & \\
Sexo/ & $\mathrm{M}$ & $597 / 5599$ & 10,7 & .55 & 10 \\
Gênero & $\mathrm{F}$ & $406 / 5317$ & 7,6 & .45 & \\
\hline Contexto & velar & $249 / 2488$ & 10 & .55 & \\
Fônico & bilabial/labiodental & $181 / 1826$ & 9,9 & .51 & \multirow{2}{*}{9} \\
Seguinte & alveolar/pós-alveolar & $457 / 5135$ & 8,9 & .48 & \\
\multicolumn{1}{c}{ pausa } & $116 / 1467$ & 7,9 & .46 & \\
\hline Identificação & - identificação & $564 / 5385$ & 10,5 & .54 & 8 \\
com a Cidade & identificação & $439 / 5531$ & 7,9 & .46 & \\
& & & & & \\
\hline Contexto & posterior & $502 / 5193$ & 9,7 & .53 & 6 \\
Fônico & anterior & $339 / 3725$ & 9,1 & .48 & \\
Anterior & central & $162 / 1998$ & 8,1 & .47 & \\
\hline & TOTAL & $1003 / 10.916$ & 9,2 & & \\
\hline
\end{tabular}

Input: 0.063

Significância: 0.017

A Tabela 9 abaixo traz os resultados da análise que, diferentemente da anterior, incluiu os grupos Posição do (-r) na Palavra, Tempo Fora, Tópico Tratado, em vez de Contexto Fônico Seguinte ao (-r), Identificação com a Cidade, Estilo e Presença de Parentes Fora. Os demais grupos de fatores (Sexo/Gênero, Faixa Etária, Frequência do Item Lexical, Contexto Fônico Precedente ao (-r), Tonicidade da Sílaba com (-r) e Classe Morfológica da Palavra) permaneceram nesta análise. Dos três grupos de fatores incluídos especificamente nesta análise, dois se revelaram correlacionados à ocorrência de tepes e fricativos

${ }^{34}$ Range é uma medida obtida a partir da subtração entre o peso relativo mais alto e o peso relativo mais baixo e dá informações acerca da importância do grupo de fatores considerado em relação à variante analisada. 
em Itanhandu: Tempo Fora e Tópico Tratado. Posição do (-r) na palavra não foi selecionado aqui, assim como Tonicidade não o havia sido na análise anterior.

Tabela 9: Outros grupos de fatores correlacionados à ocorrência de tepes $(\mathrm{T})$ e fricativos $(\mathrm{F})$

\begin{tabular}{cccccc}
\hline \multicolumn{2}{c}{ Grupos de Fatores } & $\mathrm{T}+\mathrm{F} /$ total & $\mathrm{T}+\mathrm{F} \%$ & Peso & Range \\
\hline Tempo Fora & 30\% ou mais & $423 / 2997$ & 14,1 & .81 & 76 \\
& Até $29 \%$ & $318 / 3445$ & 9,2 & .69 & \\
& Nunca & $5 / 2378$ & 0,2 & .05 & \\
\hline \multirow{4}{*}{ Tópico } & Produção/ & $171 / 1411$ & 12,1 & .56 & \\
Tratado & Percepção & & & & \\
& Linguística & & & & \\
& Opinião & $252 / 2803$ & 9 & .54 & 11 \\
& Cidade & $168 / 2376$ & 7,1 & .46 & \\
& Vida Pessoal & $155 / 2230$ & 7 & .45 & \\
\hline & TOTAL & $746 / 8820$ & 8,4 & &
\end{tabular}

Input:0.027

Significância: 0.017

O grupo de fatores Frequência do Item Lexical foi descartado das análises uma vez que só se mostrou correlação com a ocorrência de tepes e fricativos quando as palavras mais frequentes foram amalgamadas com as menos frequentes, em oposição às palavras de frequência intermediária. Tal amalgamação se baseia em razões quantitativas (GUY; ZILLES, 2007), mas parece não ligar-se a razões teóricas (GUY; ZILLES, 2007): unir palavras mais e menos frequentes contraria a hipótese inicialmente aventada (Capítulo 4).

Seguindo os ranges nas tabelas 8 e 9, os resultados sugerem que fricativos e tepes, no seu conjunto, são favorecidos: (a) entre itanhanduenses que já moraram fora; (b) entre aqueles que são da primeira e da terceira faixas etárias; (c) entre verbos e adjetivos/numerais; (d) nas leituras e nos trechos de produção e percepção linguística, ainda que o favorecimento seja leve nestes últimos casos; (e) no estilo mais cuidadoso, ou seja, na leitura da lista de palavras, da notícia e do depoimento; (f) entre os homens; (g) quando há consoantes velares no contexto fônico seguinte; (h) entre os informantes que querem sair da cidade ou que, uma vez já tendo saído, não desejam retornar a ela e (i) quando há vogais posteriores no contexto antecedente.

A seguir, trata-se detidamente de cada um desses resultados. Em cada grupo de fatores, será considerado com maior destaque o maior e o menor peso relativo, servindo o ponto neutro (.50) como parâmetro de comparação. Assim, dentro de cada variável independente, pode ser que o favorecimento/desfavorecimento seja expresso por pesos relativos distintos. 


\subsection{Tempo Fora}

Esse foi o grupo de fatores que se mostrou mais fortemente correlacionado à ocorrência de tepes e fricativos em Itanhandu (range 76, o mais alto dentre os grupos selecionados).

O conjunto dessas pronúncias é fortemente favorecido (.81) entre os itanhanduenses que estão fora da cidade $30 \%$ ou mais de suas vidas. Há também um favorecimento dessas formas, ainda que menor (relativamente ao primeiro), entre aqueles que estão até $29 \%$ de suas vidas fora de Itanhandu (.69).

De modo geral, pode-se dizer que essas variantes não prototípicas são favorecidas entre aqueles que saíram da cidade e fortemente desfavorecidas (.05) entre os itanhanduenses que nunca buscaram outros tipos de oportunidades fora de sua cidade natal. Pode-se argumentar, portanto, que a ocorrência de tepes e fricativos na fala itanhanduense parece resultar do seu contato com as variedades linguísticas de outras cidades.

Assim, quanto mais tempo se permanece fora de Itanhandu, mais os itanhanduenses tendem a produzir tepes e fricativos, já que estão, também há mais tempo, expostos a essas variantes nos outros lugares para os quais eles migraram. Os itanhanduenses também podem lançar mão dessas variantes para marcar um afastamento em relação à realidade itanhanduense ou para indexar a noção de que tiveram "boas oportunidades" fora de Itanhandu.

A seleção do grupo de fatores Tempo Fora como o mais fortemente correlacionado à ocorrência de tepes e fricativos em Itanhandu relativiza a hipótese inicial de que tais variantes estariam correlacionadas aos grupos de identificação presentes na cidade, sobretudo quando se constata que o grupo de fatores Identificação com a Cidade é o penúltimo a ser selecionado (tabela 8 - segundo menor range). Assim, parece que pronunciar a coda (-r) como tepe ou fricativo é antes algo que se dá naturalmente entre aqueles que possuem maior contato dialetal com outras variantes, do que uma questão de identidade propriamente dita. Essa questão será discutida mais detidamente no Capítulo 6.

\subsection{Faixa Etária}

Este é o segundo grupo de fatores mais fortemente correlacionado (range 55) com a variável dependente. Tepes e fricativos são favorecidos entre os informantes da terceira faixa etária (.76), mas também entre os da primeira 
(ainda que levemente) (.57). Por outro lado, essas pronúncias são fortemente desfavorecidas entre os itanhanduenses da segunda faixa etária. Não se configura, portanto, um caso de mudança em progresso - tal como ilustra a Figura 21.

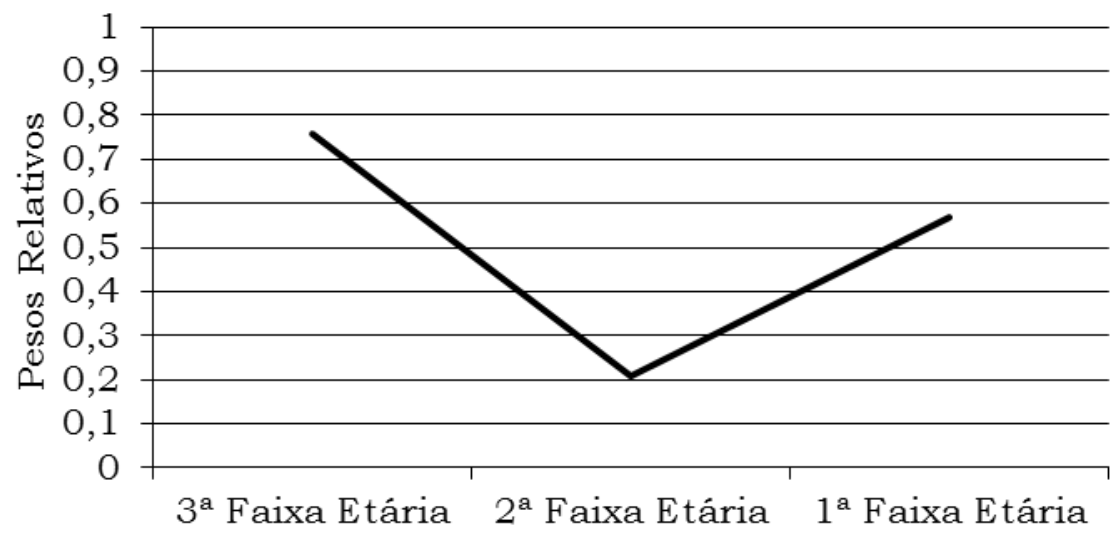

Figura 21: Correlação entre faixa etária e a pronúncia de (-r) como tepe ou fricativo

Entretanto, Faixa Etária é um grupo que pode não ser totalmente independente de Tempo Fora. Dentre os doze informantes que compõem a terceira faixa, quatro moram fora (2 no estado do Rio de Janeiro e dois no estado de São Paulo), ao passo que dos oito que moram atualmente em Itanhandu, seis já moraram fora (ou no estado de São Paulo ou no estado fluminense). Em outras palavras, apenas dois informantes da terceira faixa etária nunca moraram fora da cidade em que nasceram.

Para os itanhanduenses de terceira faixa etária que atualmente residem fora de Itanhandu, parece fácil entender sua maior tendência a usar tepes e fricativos: parece haver entre eles uma preservação do "sotaque" adquirido em outras cidades. Em certo sentido, essas pronúncias marcam aqueles que tiveram oportunidade de sair da cidade, de experimentar outro tipo de vida, de conhecer novas pessoas e novos lugares.

Dentre os informantes de primeira faixa, três moram fora (dois no estado de São Paulo e um no estado do Ceará) e dos nove que atualmente moram em Itanhandu, apenas três deles já moraram fora (um no estado de São Paulo, um no estado do Rio de Janeiro e o último no norte de Minas Gerais).

Já no que toca à segunda faixa etária, apenas dois informantes moram fora (um no estado de São Paulo e um no estado no Rio Janeiro) e dos dez 
informantes que moram atualmente na cidade, apenas quatro tiveram a oportunidade de sair de Itanhandu (três para cidades do estado de São Paulo e Rio de Janeiro e um para outra cidade de Minas Gerais).

Dessa forma, a diferença observada entre as faixas etárias no que diz respeito às ocorrências das pronúncias tepe e fricativa deve estar mais correlacionada às experiências migracionais desses indivíduos do que à sua faixa etária propriamente.

Realizou-se, então, nova análise quantitativa - agora com um grupo de fatores formado pelo cruzamento entre Faixa Etária e Tempo Fora, de acordo com o esquema da Tabela 10.

Tabela 10: Cruzamento entre Faixa Etária e Tempo Fora

\begin{tabular}{|c|c|c|c|c|}
\hline & \multicolumn{4}{|c|}{ Tempo Fora } \\
\hline \multirow{4}{*}{ Faixa Etária } & & Nunca saiu & $\begin{array}{c}\text { Saiu até } 29 \% \text { de } \\
\text { sua vida }\end{array}$ & $\begin{array}{c}\text { Saiu } 30 \% \text { ou } \\
\text { mais de sua } \\
\text { vida }\end{array}$ \\
\hline & $\begin{array}{c}1^{\text {a }} \text { Faixa } \\
\text { Etária }\end{array}$ & $\begin{array}{c}\text { Letícia } \\
\text { Raquel } \\
\text { Viviane } \\
\text { Manoel }\end{array}$ & $\begin{array}{c}\text { Heloísa } \\
\text { Daniel } \\
\text { Gustavo } \\
\text { Mauro } \\
\text { Ricardo } \\
\text { Rogério }\end{array}$ & $\begin{array}{l}\text { Cristina } \\
\text { Miranda }\end{array}$ \\
\hline & $\begin{array}{c}2^{a} \text { Faixa } \\
\text { Etária }\end{array}$ & $\begin{array}{c}\text { Clarice } \\
\text { Fernanda } \\
\text { Jorge } \\
\text { Marcos }\end{array}$ & $\begin{array}{c}\text { Lorena } \\
\text { Luiza } \\
\text { Guilherme }\end{array}$ & $\begin{array}{c}\text { Marcela } \\
\text { Regina } \\
\text { André } \\
\text { Humberto } \\
\text { Mário }\end{array}$ \\
\hline & $\begin{array}{c}3^{a} \text { Faixa } \\
\text { Etária }\end{array}$ & $\begin{array}{l}\text { Augusto } \\
\text { Josué }\end{array}$ & $\begin{array}{c}\text { Joana } \\
\text { Luciana } \\
\text { Rose } \\
\text { Antônio }\end{array}$ & $\begin{array}{c}\text { Lúcia } \\
\text { Rosângela } \\
\text { Vânia } \\
\text { Frederico } \\
\text { Joaquim } \\
\text { Leonardo }\end{array}$ \\
\hline
\end{tabular}

Tabela 11: Correlação entre Faixa Etária x Tempo Fora e a variável independente

\begin{tabular}{|c|c|c|c|c|c|}
\hline & rupos de Fatores & \multirow{2}{*}{$\begin{array}{c}\mathrm{T}+\mathrm{F} / \text { total } \\
371 / 1332\end{array}$} & \multirow{2}{*}{$\begin{array}{c}\mathrm{T}+\mathrm{F} \% \\
27,9\end{array}$} & \multirow{2}{*}{$\begin{array}{r}\text { Peso } \\
.95\end{array}$} & Range \\
\hline \multirow{9}{*}{$\begin{array}{c}\text { Faixa Etária e } \\
\text { Tempo Fora }\end{array}$} & $3^{\mathrm{a}}$ faixa etária; $30 \%$ ou + fora & & & & \multirow{9}{*}{90} \\
\hline & $3^{a}$ faixa etária; até $29 \%$ fora & $52 / 889$ & 5 & .75 & \\
\hline & $3^{\mathrm{a}}$ faixa etária; nunca saiu & $1 / 477$ & 0,2 & .09 & \\
\hline & $2^{a}$ faixa etária; $30 \%$ ou + fora & $48 / 1057$ & 4,5 & .70 & \\
\hline & $2^{a}$ faixa etária; até $29 \%$ fora & $1 / 1001$ & 0,1 & .05 & \\
\hline & $2^{a}$ faixa etária; nunca saiu & $3 / 879$ & 0,3 & .14 & \\
\hline & $1^{\mathrm{a}}$ faixa etária; $30 \%$ ou + fora & $4 / 608$ & 0,7 & .25 & \\
\hline & $1^{\text {a }}$ faixa etária; até $29 \%$ fora & $265 / 1555$ & 17 & .91 & \\
\hline & $1^{a}$ faixa etária; nunca saiu & $1 / 1022$ & 0,1 & .05 & \\
\hline & TOTAL & $746 / 8820$ & 8,4 & & \\
\hline
\end{tabular}

Input: 0.019

Significância: 0.005 
Tais resultados ficam mais claros do modo como expressos na Figura 22:

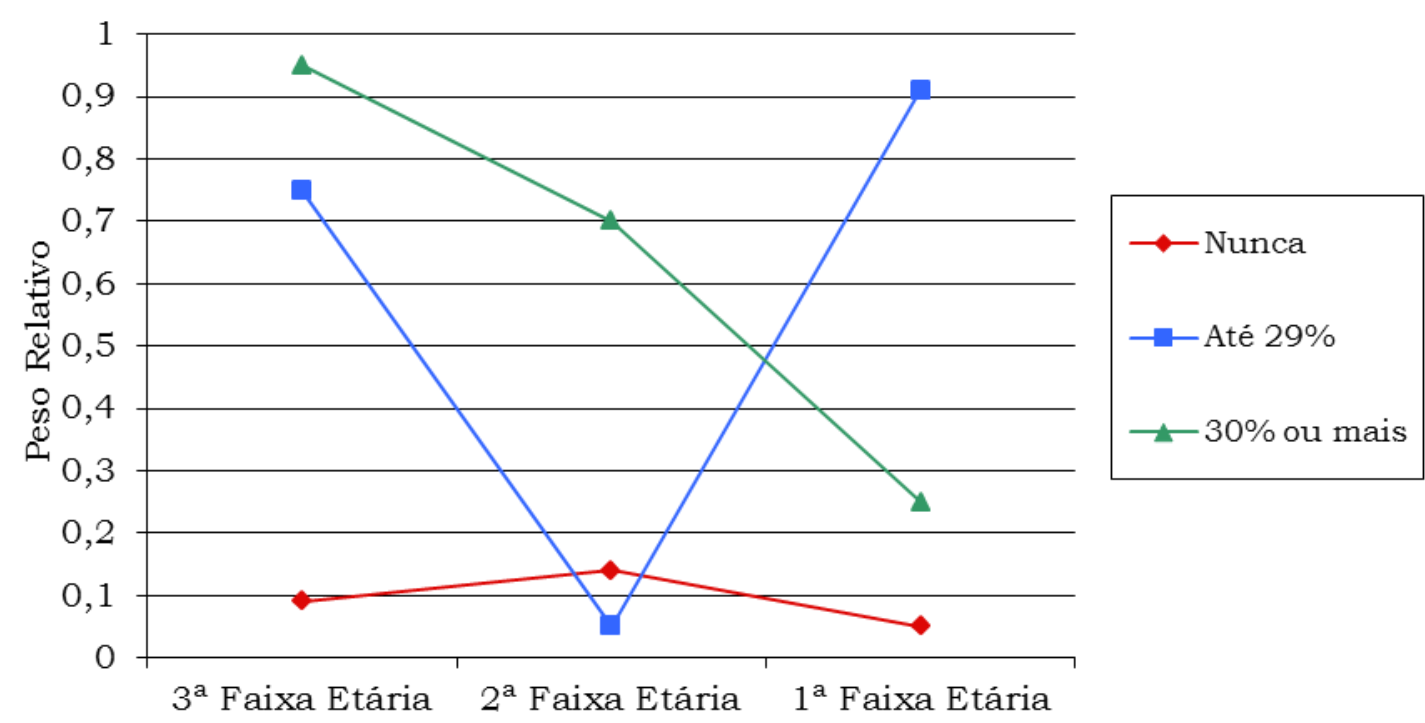

Figura 22: Resultados quantitativos para o cruzamento entre Faixa Etária e Tempo Fora

Claramente, são diferentes os padrões de variação para faixa etária em cada conjunto de itanhanduenses. Entre aqueles que nunca moraram fora (linha vermelha), praticamente não há variação, com taxas muito baixas de tepes e fricativos em todas as faixas etárias. Já entre os itanhanduense que passaram até $29 \%$ de suas vidas fora de sua cidade natal, o padrão que se revela é parecido com aquele verificado anteriormente: mais novos e mais velhos se assemelham no favorecer de tepes e fricativos, enquanto que os de idade intermediária os desfavorecem fortemente.

Já entre os informantes que passaram mais tempo fora $(30 \%$ de suas vidas ou mais), temos uma curva típica de mudança em curso - mas não em favor de tepes e fricativos, e sim em favor do retroflexo. Em outras palavras, são os mais velhos, dentre aqueles que passaram mais tempo fora de Itanhandu, que favorecem as formas não prototípicas da cidade. Relativamente a eles, os mais novos tendem bem menos a pronunciar a coda (-r) como tepe ou fricativo, mas, ainda assim, mais que os informantes dos outros subgrupos dos que nunca moraram fora.

No entanto, os valores extremos dos pesos relativos nos fatores correspondentes ao cruzamento entre até $29 \%$ e as três faixas etárias (muito 
alto para $1^{a}$ faixa etária/até $29 \%$ e muito baixo pra $2^{a}$ faixa etária/até $29 \%$ ) levam a pensar que tal resultado se deva à composição dos fatores envolvidos.

No fator até $29 \% / 2^{a}$ faixa etária, há apenas três informantes e, entre eles, ocorre tepe uma única vez. Já no fator até $29 \% / 1^{a}$ faixa etária, são seis os informantes e quatro deles produzem tepes e fricativos. De modo semelhante, no fator até $29 \% / 3^{a}$ faixa etária, há 4 informantes e essas variantes ocorrem na fala de todos.

Dessa maneira, parece que os resultados referentes aos fatores resultantes do cruzamento até $29 \%$ e as três faixas etárias se devem mais a falantes idiossincráticos do que, de fato, a uma tendência geral da comunidade de fala itanhanduense.

\subsection{Classe Morfológica da Palavra com (-r)}

O terceiro grupo com maior range é Classe Morfológica da Palavra, no qual se destacam os fatores "verbo"35 e "conjunção/preposição/advérbio". O primeiro fator evidencia-se como favorecedor (.57) e o segundo desfavorecedor (.44) de tepes e fricativos. Os dois outros fatores que compõem tal grupo de fatores ("adjetivo/numeral" e "substantivo") exibem pesos relativos bastante próximos ao ponto neutro, .54 e .48 respectivamente.

Assim, é maior a tendência de ocorrer tepes e fricativos quando a coda (-r) está presente num verbo.

Sendo os verbos palavras de conteúdo (OUSHIRO, 2015), parece que em Itanhandu tende-se ao uso de tepes e fricativos nestes elementos por terem eles grande destaque dentro das sentenças em que aparecem. Essa "preferência" se dá porque, as variantes de (-r) não prototípicas em Itanhandu recebem valorização positiva quando comparadas ao retroflexo, expectativa dialetológica local.

Opostamente, são os elementos de natureza mais gramatical, e que ocupam posições não nucleares nos sintagmas em que aparecem (conjunções, preposições e advérbios), aqueles que, com mais força, desfavorecem (-r) não prototípicos na comunidade de fala investigada. Estes elementos morfológicos possuem um destaque menor nas sentenças em que são produzidos e, por isso, tenderiam a ser realizados com o uso da variante retroflexa.

35 Nas análises realizadas, os dados de (-r) ocorrentes no morfema de infinitivo não foram separados dos (-r) ocorridos na raiz verbal. Em análises futuras, tal investigação poderá vir a ser feita. 


\subsection{Tópico Tratado}

Entre os assuntos tratados, há leve favorecimento das pronúncias tepe e fricativa nos trechos de produção e percepção linguística (.56) e naqueles em que os informantes expressam opiniões sobre alguns assuntos (.54).

Pode-se entender que tepes e fricativos sejam favorecidos nos trechos de percepção linguística por serem estes os momentos em que o informante tem certa consciência acerca de seus usos linguísticos, uma vez que discorre sobre eles e expressa julgamentos sobre seu próprio falar e sobre o falar de outras regiões.

D1: que que você acha desse jeito de dizer '(v)ocê fica sem ter o que fazer'?...

S1: olha essa é uma linguagem eu acho que mais antiga do que hoje

D1: aham

S1: eu acho que perdeu muito tanto é que quando nós (conseguimos) o nome "Arraiá do Sô João"

D1: aham

S1: foi uma brincadeira com a questão do modo de falar antigo

D1: entendi

S1: tá? porque hoje você não observa o pessoal falando "(v)ocê vai" "(v)ocê foi"

D1: aham

S1: "(v)ocê gosta?"

De modo semelhante, ao expressar opiniões, o informante tem certa preocupação com o modo pelo qual é visto pelo entrevistador - daí a ocorrência de tepes e fricativos, que tendem a ser positivamente avaliadas (Cf. Capítulo 1 , item 4) dentro da comunidade de fala itanhanduense.

No outro polo, encontram-se os tópicos "cidade" e "vida pessoal". Eles desfavorecem (.46 e .45 respectivamente) a pronúncia tepe e fricativa para o (-r). Pode-se explicar tal resultado na medida em que se entende que, como desfavorecedores de (-r) não prototípicos em Itanhandu, tais tópicos favorecem o uso de retroflexos.

Ao falar da cidade e de sua vida nela, infância, família, lazer etc, os informantes parecem aproximar-se afetivamente da realidade local e, assim, utilizar com mais frequência a variante típica da cidade, ou seja, o (-r) retroflexo.

\subsection{Estilo}

Quanto ao Estilo, é nas leituras que tepes e fricativos são favorecidos (.58). Retomando-se o conceito laboviano de estilo (Labov, 1966, 2001), quando o informante lê os textos solicitados pelo documentador, dedica 
grande atenção a essa tarefa e acaba empregando as variantes positivamente avaliadas.

Trechos da entrevista com Cristina ilustram bem fatos de atenção dedicada à leitura e o nível de consciência linguística com que o falante atua sobre sua própria fala. A informante nota, durante sua leitura da lista de palavras, sua pronúncia de (-r) como retroflexo. Ela justifica a presença de tal variante em sua fala dizendo que ainda possui muita "influência mineira".

D1: tem uma lista de palavras aqui eu queria que você lesse se você quiser ler em voz baixa primeiro

S1: tá alma amargo... está plantando... argola atitude barqueiro... biscoito caldo carteiro cerca chácara está vendo o er? [referência ao uso da variante retroflexa para o (-r)] (F1B_cristina)

Durante a leitura da notícia de jornal, a mesma informante faz mais uma vez uma avaliação acerca de seus usos linguísticos. Ela destaca a presença de nasais ditongadas em sua fala, característica fonético-fonológica comumente atribuída à cidade de São Paulo (OUSHIRO, 2015). Em momento anterior da entrevista, ela atribui esses usos linguísticos (tepes e nasais ditongadas, como no vocábulo 'tempo') ao período em que morou com "meninas de São Paulo" e adquiriu o "sotaque forte" delas.

S1: então eu até até hoje eu ainda falo aqueles enta lá aqueles trinta [vogal longa e nasalizada] ainda pego

D1: uhum

$\mathrm{S} 1$ : ainda peguei isso das meninas influência das meninas de São Paulo porque não dá para você não pegar

D1: é

S1: o sotaque de São Paulo ele é muito forte e eu morava com três de São Paulo (F1B_cristina)

\subsection{Sexo/Gênero}

A ocorrência de fricativos e tepes é levemente favorecida entre os homens (.55) e desfavorecida entre as mulheres (.45). Embora a proximidade desses pesos ao ponto neutro indique que não há grande diferenciação entre homens e mulheres no que diz respeito a essas variantes, pode-se dizer que se 
trata de um resultado diferente daquele de muitos outros estudos variacionistas que incluem tal grupo de fatores, já que, em Itanhandu, formas positivamente avaliadas (ou prestigiadas) são relativamente mais frequentes na fala de homens.

Assim como se fez com Faixa Etária, contudo, vale verificar o cruzamento do Sexo/Gênero com Tempo Fora. Em Itanhandu, é comum o trânsito de "pais de família" para fora da cidade em busca de melhores empregos. Dessa forma, muitas famílias continuam a habitar a cidade, mas já o fazem sem a presença do principal provedor da casa. Os homens, então, passam toda a semana fora de casa (às vezes por 15 dias ou um pouco mais) e voltam periodicamente aos seus lares em Itanhandu, mas por pouco tempo. Em alguns casos, o homem sai primeiro da cidade e, conseguindo se estabilizar em um "bom" emprego, volta para levar toda a família.

O cruzamento desses dois grupos de fatores objetiva, dessa forma, verificar com maior clareza o papel do sexo/gênero e do tempo fora na ocorrência das pronúncias tepe e fricativa em Itanhandu. $\mathrm{O}$ novo grupo constitui-se de seis fatores (Tabela 12).

Tabela 12: Cruzamento entre Sexo/Gênero e Tempo Fora com a distribuição dos informantes dentro dos fatores

\begin{tabular}{|c|c|c|c|c|}
\hline & & Tempo Fora & & \\
\hline \multirow{14}{*}{ Sexo/Gênero } & & $\begin{array}{l}\text { Nunca morou } \\
\text { fora }\end{array}$ & $\begin{array}{c}\text { Morou fora até } \\
29 \% \text { de sua } \\
\text { vida }\end{array}$ & $\begin{array}{l}\text { Morou fora } \\
30 \% \text { ou mais } \\
\text { de sua vida }\end{array}$ \\
\hline & \multirow{7}{*}{ Homem } & \multirow{7}{*}{$\begin{array}{c}\text { Augusto } \\
\text { Jorge } \\
\text { Josué } \\
\text { Manoel } \\
\text { Marcos }\end{array}$} & Antônio & André \\
\hline & & & Daniel & Frederico \\
\hline & & & Guilherme & Humberto \\
\hline & & & Gustavo & Joaquim \\
\hline & & & Mauro & Leonardo \\
\hline & & & Ricardo & Mário \\
\hline & & & Rogério & \\
\hline & \multirow{6}{*}{ Mulher } & \multirow{6}{*}{$\begin{array}{c}\text { Clarice } \\
\text { Fernanda } \\
\text { Letícia } \\
\text { Raquel } \\
\text { Viviane }\end{array}$} & Heloísa & Cristina \\
\hline & & & Joana & Lúcia \\
\hline & & & Lorena & Marcela \\
\hline & & & Luciana & Miranda \\
\hline & & & Luiza & Regina \\
\hline & & & Rose & Rosângela \\
\hline
\end{tabular}


Tabela 13: Correlação do grupo de fatores Sexo/Gênero e Tempo Fora com a variável dependente

\begin{tabular}{cccccc}
\hline Grupo de Fatores & $\begin{array}{c}\text { Tepe }+ \\
\text { Fricativo } \\
\text { Total }\end{array}$ & $\begin{array}{c}\text { Tepe }+ \\
\text { Fricativo \% }\end{array}$ & Peso & Range \\
& Homens; 30\% ou + & $209 / 1429$ & 14,6 & .82 & \\
Mulheres; 30\% ou + & $214 / 1568$ & 13,6 & .77 & \\
Sexo/Gênero & Homens; até 29\% & $259 / 1876$ & 13,8 & .80 & \multirow{2}{*}{ Tempo Fora } \\
& Mulheres; até 29\% & $59 / 1569$ & 3,8 & .51 & 78 \\
& Homem; nunca saiu & $2 / 1252$ & 0,2 & .04 & \\
& Mulher; nunca saiu & $3 / 1126$ & 0,3 & .08 & \\
\hline Input: 0.027 & TOTAL & $746 / 8820$ & 8,5 & & \\
\hline & & & Significância: 0.003
\end{tabular}

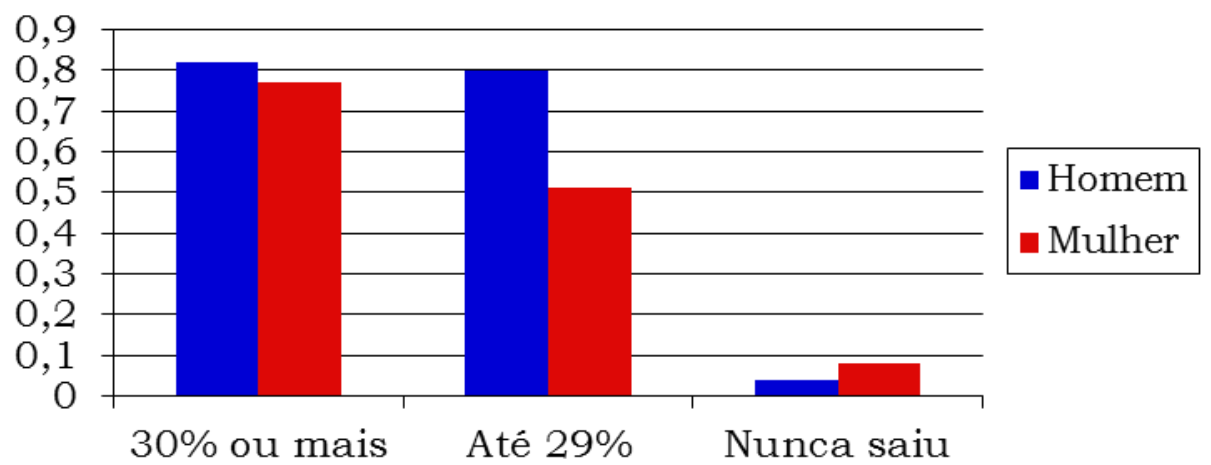

Figura 23: Cruzamento entre Sexo/Gênero e Tempo Fora

Diferentemente do que se havia imaginado, a figura acima mostra que Sexo/Gênero e Faixa Etária são dois grupos de fatores relativamente independentes entre si. Tepes e fricativos são mais frequentes na fala dos homens, nos dois grupos que já viveram um tempo fora de Itanhandu. Esse padrão é diferente entre aqueles que nunca viveram fora de Itanhandu. Observe-se, contudo, que, neste caso, são muito raros os dados: 3 entre as mulheres, 2 entre os homens.

Note-se ainda a distinção entre homens e mulheres a depender de quanto tempo viveram fora: para os primeiros, ter vivido mais de $30 \%$ ou até $29 \%$ de suas vidas fora de Itanhandu praticamente não faz diferença para sua tendência de pronunciar a coda $(-r)$ como tepe ou fricativo $(.82$ e .80 respectivamente); já para as mulheres, o quadro é outro - para aquelas que ficaram mais tempo fora a tendência é semelhante à dos homens do mesmo grupo (.77), mas para aquelas que moraram fora até $29 \%$ de suas vidas, tal tendência cai para .51 (ou seja, pode-se dizer que não há favoreciemento neste caso). 
Tais resultados indicam que, apesar de tepes e fricativos serem variantes bem avaliadas em Itanhandu, elas são mais frequentes na fala dos homens (o que contrasta com grande parte dos trabalhos variacionistas em que são as mulheres as maiores veiculadoras da variante de prestígio). Isso se deve em grande parte à pressão sofrida pelos homens quando se mudam de Itanhandu em busca de melhores oportunidades de emprego e renda e passam por uma "adequação" linguística , ou seja, passam a usar tepes e fricativos, já que, grande parte das vezes, essa migração se dá em direção ao estado do Rio de Janeiro ou à capital paulista.

Além disso, o favorecimento da pronúncia tepe e fricativa entre os homens se originaria no fato de que tais usos teriam, como um de seus significados sociais, a ideia de "pessoa bem sucedida" ou que, ao menos, teve a chance de buscar novas oportunidades para si e para sua família fora da cidade em que nasceu.

\subsection{Contexto Fônico Seguinte ao (-r)}

Para esse grupo de fatores (cujo range é 9), destaca-se que sons velares no contexto seguinte favorecem (.55) a ocorrência de tepes e fricativos, e que pausas os desfavorecem (.46). Os demais fatores (bilabiais/labiodentais e alveolares/ pós-alveolares) ficam bem próximos ao ponto neutro.

As pronúncias de (-r) não prototípicos que ocorrem antes das consoantes velares são, em sua enorme maioria (89,5\% dos casos), exemplos de (-r) fricativos produzidos em sua forma velarizada, variante comumente atribuída ao falar carioca (CRISTÓFARO SILVA, 2002 [1998]). O que parece ocorrer, dessa forma, é uma assimilação regressiva de traços das velares ( $k$ e g). Como os dados de (-r) tepes antes das consoantes velares são poucos (10,5\% dos dados), eles influenciam também pouco o favorecimento notado entre esse tipo de consoante e a presença de (-r) não prototípicos, ou seja, deve-se à presença majoritária de (-r) fricativos, dentre os (-r) não prototípicos, o fato de haver favorecimento do emprego dessas variantes quando se tem uma consoante velar no contexto fônico seguinte.

As outras possibilidades de amalgamações das consoantes, seja por vozeamento, seja por modo de articulação, também foram testadas, mas não se mostraram correlacionadas à variação investigada. 


\subsection{Identificação com a Cidade}

Embora seja baixo o range para esse grupo de fatores (8), confirma-se a hipótese inicialmente aventada. Tepes e fricativos tendem a ocorrer mais na fala dos informantes que compõem o grupo de itanhanduenses menos identificados com a cidade (.54), relativamente aos informantes que compõem o subgrupo de identificação daqueles mais identificados com a realidade local (.46).

Esse resultado, ao mesmo tempo, permite reforçar o que se entende pelo conceito de "identidade" (ver Capítulo 2). Sendo a identidade algo fluido, já que os significados sociais atribuídos às variantes são igualmente fluidos, não é algo fácil de se delinear em Itanhandu, fato que parece estar refletido na posição próxima do ponto neutro ocupada pelos pesos relativos dos fatores que compõem esse grupo de fatores.

Conforme já se indicou anteriormente, os grupos de fatores "Tempo Fora" e "Identificação com a cidade" interagem entre si, pois dois fatores resultantes do cruzamento deles não existem dentro da realidade da amostra coletada: itanhanduenses que nunca tenham saido da cidade e sejam do grupo de identificação B (composto dos informantes menos identificados com a cidade), e itanhanduenses do grupo de identificação A (pessoas mais identificadas com a cidade) que tenham morado $30 \%$ ou mais de suas vidas fora de sua cidade natal.

A Tabela 14 mostra a distribuição dos informantes pelos fatores resultantes do cruzamento entre Tempo Fora e Identificação com a Cidade:

Tabela 14: Cruzamento entre Tempo Fora e Identificação com a cidade

\begin{tabular}{|c|c|c|c|c|}
\hline & \multicolumn{4}{|c|}{ Tempo Fora } \\
\hline & & $\begin{array}{c}\text { Nunca morou } \\
\text { fora }\end{array}$ & $\begin{array}{c}\text { Morou fora até } \\
29 \%\end{array}$ & $\begin{array}{c}\text { Morou fora } \\
30 \%+\end{array}$ \\
\hline $\begin{array}{l}\text { Identificação } \\
\text { com a Cidade }\end{array}$ & Grupo A & $\begin{array}{c}\text { Clarice } \\
\text { Fernanda } \\
\text { Letícia } \\
\text { Raquel } \\
\text { Viviane } \\
\text { Augusto } \\
\text { Jorge } \\
\text { Josué } \\
\text { Manoel } \\
\text { Marcos }\end{array}$ & $\begin{array}{c}\text { Joana } \\
\text { Luciana } \\
\text { Luiza } \\
\text { Rose } \\
\text { Antônio } \\
\text { Daniel } \\
\text { Guilherme } \\
\text { Rogério }\end{array}$ & \\
\hline
\end{tabular}




\begin{tabular}{c|c|c|c|c}
\hline & & & Cristina \\
& & & Lúcia \\
& & & Marcela \\
& & Miranda \\
& & Heloísa & Regina \\
& & Lorena & Rosângela \\
& & Gustavo & Vânia \\
& & Mauro & André \\
& & Ricardo & Frederico \\
& & & Humberto \\
& & & Joaquim \\
& & & Leonardo \\
& & & Mário \\
& & & \\
& & & \\
\end{tabular}

Tabela 15: Correlação entre Identificação com a Cidade $x$ Tempo Fora e a variável dependente

\begin{tabular}{ccccccc}
\hline \multicolumn{2}{c}{ Grupo de Fatores } & $\begin{array}{c}\text { Tepe }+ \\
\text { Fricativo/ } \\
\text { Total }\end{array}$ & $\begin{array}{c}\text { Tepe }+ \\
\text { Fricativo \% }\end{array}$ & Peso & Range \\
& & $303 / 2125$ & 14,3 & .830 & \\
\hline Identificação & Grupo A; até 29\% & 30378 & 0,2 & .06 & \multirow{2}{*}{77} \\
com a Cidade & Grupo A; nunca saiu & $5 / 2378$ & 14,1 & .827 & .25 & \\
e & Grupo B; 30\% ou + & $423 / 2997$ & 1,1 & .25 \\
Tempo Fora & Grupo B; até 29\% & $15 / 1320$ & \multicolumn{5}{c}{ Significância:0.004 }
\end{tabular}

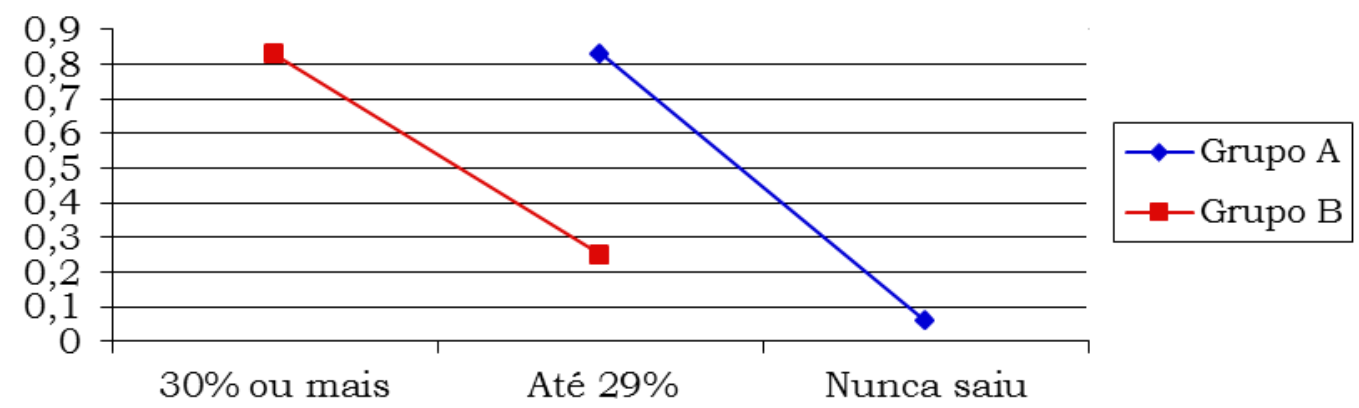

Figura 24: Resultados para a correlação entre Identificação com a Cidade e Tempo Fora com a variável dependente

Os resultados mostram que, independentemente do grupo de identificação, quanto mais tempo se vive fora de Itanhandu, mais se tende ao uso das variantes tepes e fricativas para o $(-\mathrm{r})$ - o que reforça as interpretações no item 2.1. De maneira semelhante ao que se observou para Sexo/Gênero, Tempo Fora é uma variável bastante importante para explicar a atuação do grupo de fatores Identificação com a Cidade. Não basta ser de um ou outro grupo de identificação, mas sim a relação disso com o tempo vivido fora de Itanhandu. 


\subsection{Contexto Fônico Precedente ao (-r)}

Este é o grupo de fatores com menor range (apenas 6): as vogais posteriores no contexto precedente favorecem muito levemente a ocorrência de tepes e fricativos (.53), ao passo que vogais centrais e anteriores os desfavorecem também muito levemente (.47 e .48 respectivamente).

O que parece haver é uma assimilação progressiva de traços, ou seja, as vogais posteriores espraiam o traço [+posterior] e atingem o rótico de modo a favorecer os (-r) não prototípicos, com destaque para os (-r) fricativos.

\section{Graus de retroflexão}

As análises reportadas acima tratam da variável "tepes e fricativos (em conjunto) versus retroflexos". Conforme vimos nos capitulos introdutórios, o interesse de tal análise está em verificar quais variáveis sociais e linguísticas (grupos de fatores) se correlacionam à ocorrência de pronúncias em princípio não esperadas numa cidade do sul de Minas Gerais. Vimos acima que Tempo Fora e Faixa Etária são as variáveis que mais fortemente explicam tais ocorrências, seguidas de Classe Morfológica da Palavra (cujo range é bem menor).

Durante a análise qualitativa das entrevistas, contudo, paralelamente à verificação do total de ocorrências de tepes e fricativos (da ordem de 10\%), verificou-se também que os itanhanduenses reconhecem que a pronúncia do (-r) "comum" na cidade pode ser "mais fraca" ou "mais forte" (Item 3, Capitulo 1) . Tal "pronúncia comum" - a variante retroflexa - constitui, na verdade, ela também, uma variável: retroflexos fracos (menor duração, menor intensidade) e retroflexos fortes (maior duração, maior intensidade). Considerando-se que, na comunidade itanhanduense em geral, essas pronúncias retroflexas são as mais frequentes, interessa verificar sua estratificação sociolinguística. Em outras palavras: que fatores sociais e linguísticos se correlacionam à ocorrência dessas pronúncias?

A Tabela 16 traz a distribuição dessas variantes retroflexas. Conforme vimos na Tabela 7 , são 10.916 ocorrências de (-r) no total, das quais 1003 são casos de tepes e fricativos. O total de retroflexos, então, é 9.913, dos quais $14 \%$ são representados por retroflexos fracos. O retroflexo forte é, portanto, a forma mais frequente na cidade - o que, de certa forma, confirma a expectativa dialetológica para o Sul de Minas (RIBEIRO et al., 1977). O que nos interessa 
no presente item, portanto, é verificar o que se correlaciona à produção de retroflexos fracos pelos itanhanduenses, ou seja, seu estatuto sociolinguístico.

Tabela 16: Distribuição de retroflexos fortes e fracos em Itanhandu - MG

\begin{tabular}{ccc}
\hline Tipo de Retroflexão & $\mathrm{N}^{\circ}$ de ocorrências & $\%$ \\
"Forte" & 8.523 & 86 \\
"Fraco" & 1.390 & 14 \\
\hline TOTAL & 9.913 & 100 \\
\hline
\end{tabular}

Assim como no caso da análise de tepes e fricativos, uma das variantes é bem menos frequente e não há ortogonalidade entre alguns grupos, nos quais foram feitas amalgamações de fatores. Tais grupos e amalgamações são os mesmos da análise anteriormente apresentada (Quadro 6).

Análises quantitativas distintas foram também necessárias uma vez que havia interações intrínsecas entre determinados grupos de fatores, o que fez com que fossem considerados em rodadas diferentes. Tempo de Permanência Fora de Itanhandu, Posição do (-r) na palavra e Tópico Tratado (constantes na Tabela 17 abaixo) foram analisados separadamente de Identificação com a Cidade, Contexto Fônico Seguinte ao (-r) e Estilo (reportados na Tabela 18 também abaixo).

O grupo de fatores Parentes Fora, não incluído na análise anterior (já que não era ortogonal com a maioria dos demais grupos) foi considerado aqui.

As Tabelas 17 e 18 organizam os grupos selecionados como estatisticamente significativos na correlação com a variável em questão.

Tabela 17: Grupos de fatores correlacionados ao (-r) retroflexo fraco

\begin{tabular}{cccccc}
\hline & Grupos de Fatores & $\begin{array}{c}\text { retroflexos } \\
\text { fracos/total }\end{array}$ & $\%$ & Peso & Range \\
& & & & & \\
\hline Classe & conjunção/preposição/advérbio & $609 / 1.916$ & 31,8 & .66 & \\
Morfológica & adjetivo/numeral & $171 / 1.541$ & 11,1 & .49 & \multirow{2}{*}{35} \\
da Palavra & substantivo & $390 / 3.527$ & 11,1 & .47 & \\
& verbo & $63 / 1.090$ & 5,8 & .31 & \\
\hline Frequência & + de 180 vezes & $644 / 2.441$ & 26,4 & .59 & \\
do Item & De 41 a 180 vezes & $316 / 2.463$ & 12,8 & .50 & 16 \\
Lexical & Até 40 vezes & $273 / 3.170$ & 8,6 & .43 & \\
\hline Faixa Etária & 18 a 30 anos & $412 / 2.915$ & 14,1 & .49 & \\
& 31 a 45 anos & $378 / 2.885$ & 13,1 & .46 & \multirow{2}{*}{11} \\
\hline Tempo Fora & 46 anos ou + & $443 / 2.274$ & 19,5 & .57 & \\
de & $30 \%$ ou + & $483 / 2.574$ & 18,8 & .56 & \\
Itanhandu & até $29 \%$ & $443 / 3.127$ & 14,2 & .48 & 10 \\
\hline Sexo/gênero & nunca saiu & $307 / 2.373$ & 12,9 & .46 & \\
\hline
\end{tabular}




\begin{tabular}{cccccc}
\hline & Mulheres & $534 / 3.987$ & 13,4 & .45 & \\
\hline & Opinião & $431 / 2.551$ & 16,9 & .519 & \\
Tópico & Cidade & $348 / 2.208$ & 15,8 & .516 & \\
Tratado & Produção/Percepção & $190 / 1.240$ & 15,3 & .51 & 6 \\
& Vida Pessoal & $264 / 2.075$ & 12,7 & .46 & \\
\hline $\begin{array}{c}\text { Posição da } \\
\text { silaba com } \\
\text { (-r) }\end{array}$ & fim & $400 / 2.090$ & 19,1 & .54 & 5 \\
\hline & meio & $833 / 5.984$ & 13,9 & .49 & \\
\hline Input: 0.126 & TOTAL & $1.233 / 8.074$ & 15,3 & \\
& & & \multicolumn{3}{c}{ Significância: 0.025}
\end{tabular}

Apenas o grupo Presença de Parentes Fora de Itanhandu não foi selecionado como estatisticamente significativo. A produção de retroflexos fracos, portanto, não depende dessa variável e a hipótese inicial não se confirma.

Na segunda análise, vista a seguir, todos os grupos de fatores incluídos foram selecionados como estatisticamente significativos, inclusive Presença de Parentes Fora de Itanhandu (note-se, contudo, que está entre aqueles com menor range).

Tabela 18: Outros grupos de fatores correlacionados ao (-r) retroflexo fraco

\begin{tabular}{|c|c|c|c|c|c|}
\hline \multicolumn{2}{|c|}{ Grupos de Fatores } & $\begin{array}{c}(-\mathrm{r}) \\
\text { fracos } / \text { total }\end{array}$ & $\begin{array}{c}(-r) \\
\text { fracos } \\
\%\end{array}$ & Peso & Range \\
\hline Contexto Fônico & posterior & $971 / 4.691$ & 20,7 & .57 & \multirow{3}{*}{16} \\
\hline \multirow{2}{*}{ Precedente } & anterior & $275 / 3.386$ & 8,1 & .45 & \\
\hline & central & $144 / 1.836$ & 7,8 & .41 & \\
\hline \multirow{4}{*}{$\begin{array}{l}\text { Contexto Fônico } \\
\text { Seguinte }\end{array}$} & velar & $555 / 2.239$ & 24,8 & .58 & \multirow{4}{*}{12} \\
\hline & pausa & $230 / 1.351$ & 17 & .55 & \\
\hline & bilabial/lábio-dental & $163 / 1.645$ & 9,9 & .47 & \\
\hline & alveolar/pós-alveolar & $442 / 4.678$ & 9,4 & .46 & \\
\hline \multirow[t]{2}{*}{ Estilo } & Entrevista & $1233 / 8.074$ & 15,3 & .52 & \multirow[t]{2}{*}{9} \\
\hline & Outros & $157 / 1.839$ & 8,5 & .43 & \\
\hline \multirow{2}{*}{$\begin{array}{c}\text { Graus de } \\
\text { Identificação com } \\
\text { a Cidade }\end{array}$} & - identificação & $746 / 4.821$ & 15,5 & .52 & \multirow[b]{2}{*}{4} \\
\hline & + identificação & $644 / 5.092$ & 12,6 & .48 & \\
\hline \multirow{3}{*}{$\begin{array}{l}\text { Presença (ou não) } \\
\text { de Parentes Fora }\end{array}$} & Possui & $876 / 5524$ & 15,9 & .52 & \multirow[t]{2}{*}{4} \\
\hline & Não Possui & $514 / 4389$ & 11,7 & .48 & \\
\hline & TOTAL & $1.390 / 9.913$ & 14 & & \\
\hline
\end{tabular}

Input: 0.017

Significância: 0.038

É notável que a ocorrência de retroflexos fracos correlaciona-se mais fortemente a grupos de fatores linguísticos - todos os grupos sociais apresentam range menor ou igual a 11. Assim, esta variável não tem o mesmo estatuto sociolinguístico de "tepes/fricativos versus retroflexos". Observe-se 
que Tempo Fora e Faixa Etária (grupos com maiores ranges na análise anterior) aqui apresentam ranges bem menores.

Nos itens a seguir, discutem-se os resultados para cada um desses grupos de fatores.

\subsection{Classe Morfológica da Palavra com (-r)}

Este é o grupo de fatores mais fortemente correlacionado à ocorrência de retroflexos fracos (range 35), que são favorecidos em conjunções, preposições e advérbios (.65) e desfavorecidas em verbos (.36).

O fator "conjunções/preposições/advérbios" reúne sobretudo os itens lexicais "por" e "porque". O que parece ocorrer em Itanhandu, então, é um enfraquecimento do rótico (retroflexo fraco) em palavras mais gramaticais, ou seja, naquelas que desempenham funções mais estruturais na sentença.

Já com os verbos, é possivel que, dada a natureza de seu conteúdo semântico, a tendência de enfraquecimento do elemento rótico diminua notadamente (OUSHIRO, 2015).

\subsection{Frequência do Item Lexical}

Esse grupo é aquele com o segundo maior range (16) na Tabela 17. De acordo com Dinkin $(2004,2007)$, o efeito da frequência restringe-se a mudanças lenitivas, ou seja, aquelas que envolvem um processo fonológico de enfraquecimento da articulação das consoantes, provocando desvozeamento, aspiração ou apagamento desses segmentos linguísticos. Ainda que não se verifique mudança em Itanhandu na direção do retroflexo fraco (conforme se discute mais adiante), observa-se que o enfraquecimento do retroflexo é mais presente em palavras de alta frequência na amostra. Na tabela 19 a seguir, é possivel verificar os vocábulos mais frequentes na amostra:

Tabela 19: Vocábulos mais frequentes na mostra itanhanduense

\begin{tabular}{cc}
\hline Vocábulo & $\mathrm{N}^{\mathrm{o}}$ ocorrências \\
\hline porque/porquê & 1.695 \\
\hline por & 762 \\
\hline falar & 394 \\
\hline fazer & 383 \\
\hline ser & 322 \\
\hline parte & 321 \\
\hline
\end{tabular}




\begin{tabular}{cc}
\hline ter & 303 \\
\hline ir & 273 \\
\hline quer & 261 \\
\hline melhor & 222 \\
\hline perto & 202 \\
\hline ficar & 188 \\
\hline lugar & 186 \\
\hline
\end{tabular}

\subsection{Contexto Fônico Precedente}

Verifica-se que vogais posteriores favorecem a ocorrência de retroflexos fracos (.57), enquanto que vogais centrais os desfavorecem (.41). As anteriores ficam mais próximas do ponto neutro.

Esse resultado se alinha com relações acústicas, de acordo com certos autores (LEITE, 2010; HAGIWARA, 1995). Leite (2010) afirma:

\footnotetext{
A frequência de F2 está associada ao recuo da língua durante a produção da vogal de tal forma que, quanto menos recuado está o corpo da língua, mais alto é o F2. Assim, se há um aumento de F2, significa que, durante a trajetória VR , a língua se move para a frente e, em decorrência, o F2 se aproxima de F3, esse parece ser o comportamento do F3 da sequência VR na PM e PF quando vogais posteriores antecedem o rótico.

(LEITE, 2010: 100)
}

As vogais posteriores, afirma Ferraz (2005), tendem a provocar um maior abaixamento de F2 e F3 da consoante que a segue ou tendem a causar enfraquecimento de algum componente circundante. No caso aqui em análise, parece que a presença de vogais posteriores no contexto fônico precedente favorece a pronúncia de (-r) retroflexo fraco justamente porque, ao enfraquecer o prototípico (-r) retroflexo, geram tal variante.

Já as vogais centrais tenderiam a desfavorecer o (-r) retroflexo fraco porque, em princípio, não haveria nelas nenhum traço passivel de ser assimilado progressivamente por esta consoante, visto que se trata de um som consonantal realizado com a ponta da lingua voltada para a parte posterior do trato vocal em movimento de aproximação (mas não há contato, uma vez que se trata de uma consoante aproximante) com a região palatal. 


\subsection{Contexto Fônico Seguinte ao (-r)}

Os resultados para esse grupo de fatores, cujo range é menor que os anteriores (12), indicam que retroflexos fracos são favorecido quando seguidos de consoantes velares e pausas (P.R .58 e .55 respectivamente). Bilabiais/lábio-dentais e as alveolares/pós-alveolares desfavorecem tal variante (.47 e .46 respectivamente).

O retroflexo fraco parece ser realizado com uma curvatura menor da língua em comparação ao retroflexo forte, o que o faria ser produzido em uma região mais posterior do trato vocal, isto é, em região próxima a das consoantes que o favorecem. Já as bilabiais/labiodentais e alveolares/pósalveolares compartilham o traço [+anterior], desfavorecendo o retroflexo fraco, cuja região de articulação parece ser [+ posterior].

\subsection{Faixa Etária}

O retroflexo fraco é favorecido entre os informantes da terceira faixa etária (.57) e levemente desfavorecido entre os informantes da primeira e da segunda (.48 e .47 respectivamente), conforme ilustra a Figura 25:

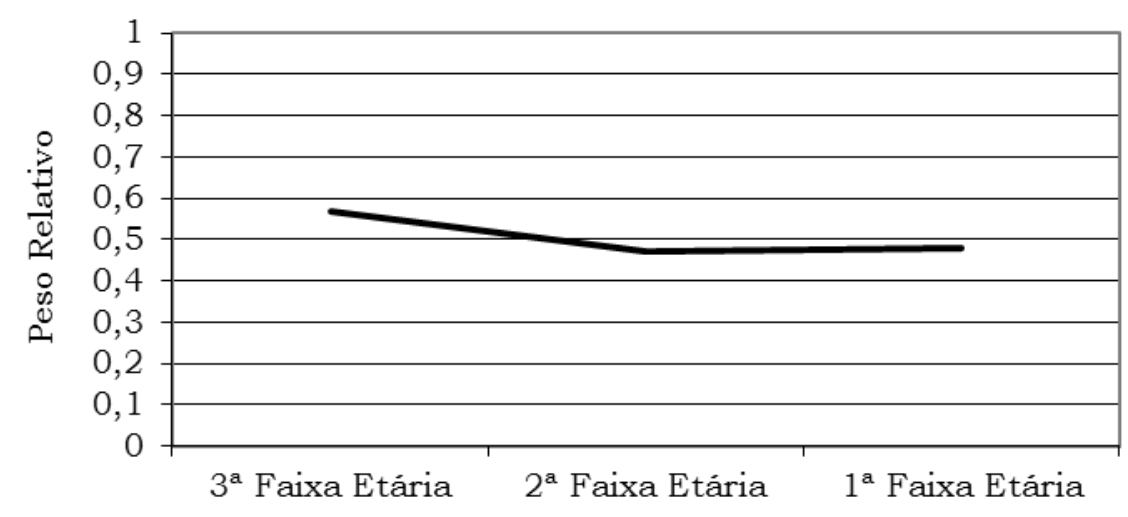

Figura 25: Correlação entre Faixa Etária e (-r) retroflexo fraco

Para os itanhanduenses mais velhos, é possivel que a pronúncia fraca para o retroflexo represente uma "alternativa linguística", entre o retroflexo mais forte (que, pode-se dizer, é mais prototípico na cidade) e as outras variantes - tepes e fricativos (lá presentes ou com as quais tais informantes tenham convivido durante o tempo que passaram fora da cidade). Deve-se lembrar aqui que são os itanhanduenses mais velhos aqueles que em maior quantidade formam o grupo de pessoas que viveram (ou vivem) fora de Itanhandu $30 \%$ ou mais de suas vidas. 


\subsection{Demais Grupos de Fatores}

Os demais grupos de fatores que foram selecionados como estatisticamente significativos - Tópico Tratado, Estilo, Tempo Fora, Sexo/gênero, Presença de Parentes Fora e Identificação com a Cidade apresentam pesos relativos bastante próximos do ponto neutro e são aqui tratados em conjunto.

Para Tópico Tratado, "vida pessoal" desfavorece (.46) o retroflexo fraco. Os demais fatores são neutros. É possível que isso se deva ao fato de que, ao discorrer sobre sua vida pessoal, o informante faça um movimento de aproximação com a cidade na qual nasceu e passou grande parte de sua vida. Como consequência disso, o retroflexo forte ocorrendo ainda mais (relativamente aos outros tópicos).

Quanto a Estilo, retroflexos fracos são desfavorecidos (.43) nas leituras de textos, nos quais o informante dedica maior atenção à sua fala.

Para Tempo Fora, retroflexos fracos são favorecidos levemente (.53) entre informantes que moram (ou moraram) fora por pelo menos $30 \%$ de suas vidas, ao passo que tal variante é desfavorecida (.45) entre itanhanduenses que nunca saíram de sua cidade natal.

Quanto à variável sexo/gênero, o retroflexo fraco é favorecido entre os homens (.54) e desfavorecido entre as mulheres (.46).

Próximo ao que ocorre com o favorecimento de $(-r)$ tepes e fricativos pelos homens em Itanhandu, a pronúncia fraca do (-r) também se liga ao sexo masculino.

Já para a variável Parentes Fora, o retroflexo fraco é muito levemente desfavorecido entre os itanhanduenses que não possuem parentes fora da cidade (.48). Isso parece decorrer de um contato menor com outras variantes de $(-r)$.

Acerca do grupo de fatores Posição da Sílaba com (-r), o resultado indica que fim de palavra favorece (.54) retroflexos fracos. Esse resultado se alinha com a consideração de que há uma aproximação entre pronúncia enfraquecida e apagamento; em outras palavras, esse resultado se aproxima dos achados de Votre (1978 apud REIS; DIAS, 2006), Callou (1979 apud REIS; DIAS, 2006) e Mollica (1997), que indicam maior taxa de apagamento do (-r) quando em posição final, destacadamente em verbos no infinitivo.

Sobre Identificação com a Cidade (que apresenta o menor range - 4), enquanto os retroflexos fracos são levemente favorecidos entre os informantes 
que se identificam menos com a cidade (.52), são levemente desfavorecidos entre os informantes que se identificam bastante com a cidade e seus moradores (.48). Usar (-r) retroflexo forte ou (-r) retroflexo fraco, ao que tudo indica, parece não ajudar a identificar uma pessoa como mais ou menos itanhanduense, uma vez que tais formas parecem não ser avaliadas socialmente dentro de Itanhandu.

O conjunto dos resultados aqui reportados evidencia que a variação, em termos de graus de retroflexão em Itanhandu, não se correlaciona fortemente à diferenciação social entre subgrupos de itanhanduenses - nem em termo de identificação com a cidade ou tempo fora dela, nem em termos de sexo/gênero e faixa etária. Conforme os resultados, a variável "graus de retroflexão" é regulada, sobretudo por fatores linguísticos, notadamente Classe Morfológica e Contexto Fônico.

No capítulo a seguir, a investigação volta-se ao uso de (-r) tepes e fricativos em Itanhandu, propondo uma análise que vá em direção ao nível do indivíduo. Tal análise evidencia-se como relevante porque investiga mais a fundo o grupo de fatores "Identificação com a Cidade" e busca entender mais profundamente o uso de tepes e fricativos, usos, ao que tudo indica, mais ligados a indivíduos específicos do que à comunidade itanhanduense como um todo. 


\section{Capitulo 6: Análise no nivel do individuo}

Diferentemente da hipótese originalmente aventada, o grupo de fatores Identificação com a Cidade, embora se correlacione à ocorrência das variantes tepe e fricativa em Itanhandu, foi um dos últimos grupos de fatores a ser selecionado na análise quantitativa. Por outro lado, o grupo Tempo de Permanência Fora da Cidade mostrou-se fortemente correlacionado a esse caso de variação. Dessa forma, no presente capitulo, procede-se a uma análise mais aproximada dos indivíduos em cuja fala essas pronúncias de fato ocorrem.

Alguns conceitos caros aos estudos sociolinguísticos de terceira onda (Capítulo 2), sobretudo stance (“tomada de posição") (KIESLING, 2009), e o conceito de atitudes linguísticas (ECKERT, 2008), no que diz respeito às variáveis de (-r), também lançam luz à compreensão do fenômeno linguístico estudado neste trabalho.

Nesse sentido, os 36 informantes da amostra coletada dividem-se em quatro grupos: (a) aqueles em cuja fala ocorrem somente retroflexos; (b) aqueles que, além da variante prototípica da cidade, pronunciam o (-r) como tepe; (c) aqueles que produzem retroflexos e fricativos e (d) aqueles em cuja fala ocorrem as três variantes.

Tabela 20: Distribuição dos informantes por ocorrência de (-r) realizado

\begin{tabular}{|c|c|c|c|c|}
\hline \multirow[t]{2}{*}{ Informante } & \multicolumn{4}{|c|}{ Variantes } \\
\hline & \multicolumn{4}{|c|}{ Só Retroflexos } \\
\hline F1A_letícia & \multicolumn{4}{|c|}{311} \\
\hline F1A_raquel & \multicolumn{4}{|c|}{369} \\
\hline F2A_luiza & \multicolumn{4}{|c|}{435} \\
\hline F2B_marcela & \multicolumn{4}{|c|}{242} \\
\hline F3B_vânia & \multicolumn{4}{|c|}{304} \\
\hline M1A_manoel & \multicolumn{4}{|c|}{326} \\
\hline M1A_rogério & \multicolumn{4}{|c|}{367} \\
\hline M2A_guilherme & \multicolumn{4}{|c|}{353} \\
\hline M2A_jorge & \multicolumn{4}{|c|}{266} \\
\hline \multirow[t]{3}{*}{ M1B_mauro } & \multicolumn{4}{|c|}{377} \\
\hline & \multicolumn{4}{|c|}{ Retroflexos e Tepes } \\
\hline & Retroflexo & Tepe & Total & \% Tepe \\
\hline F1A_viviane & 247 & 1 & 248 & 0,4 \\
\hline F2A_fernanda & 294 & 4 & 298 & 1,3 \\
\hline F1B_cristina & 292 & 1 & 293 & 0,3 \\
\hline F1B_heloisa & 307 & 11 & 318 & 3,5 \\
\hline
\end{tabular}




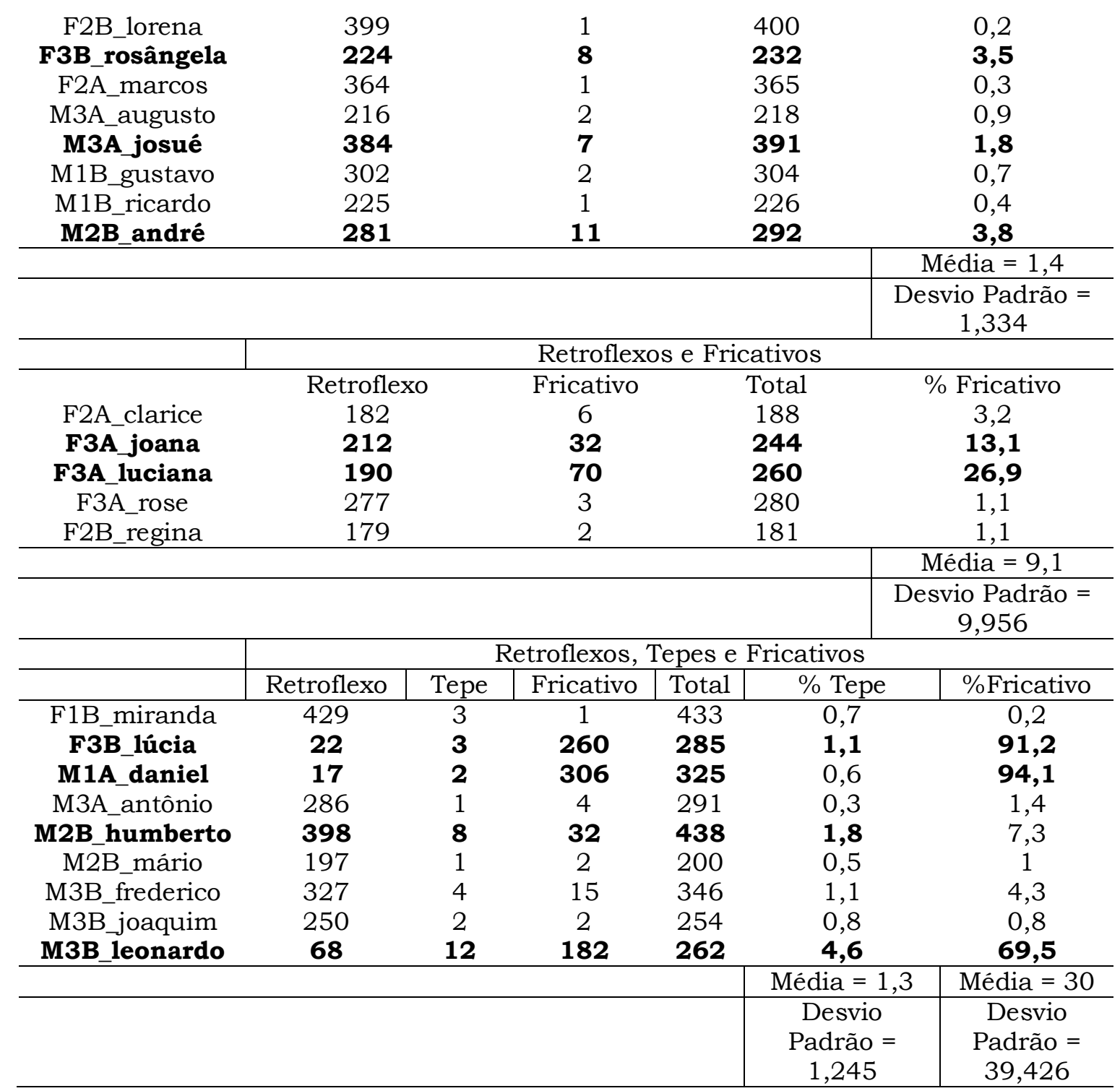

$\mathrm{Na}$ Tabela 20, o desvio padrão, calculado para cada variante nos distintos grupos de informantes, indica o grau de variação de um conjunto de elementos.

No grupo dos cinco itanhanduenses que têm retroflexos e fricativos, o desvio padrão para a variante fricativa é consideravelmente alto, sobretudo se comparado ao valor desse desvio no grupo de falantes que realiza tepes e retroflexos. O desvio padrão para as fricativas fica ainda maior quando se consideram as ocorrências dessa variante no grupo daqueles que possuem tepes, fricativos e retroflexos em sua fala.

Isso mostra que há grande variabilidade entre os informantes em cuja fala ocorre /-r/ fricativo. De um lado, há aqueles que frequentemente empregam tal variante; de outro, há aqueles que o fazem com baixa frequência. 
Entretanto, deve-se notar que, apesar de distribuída irregularmente, tal variante faz-se presente na fala de mais de um terço dos itanhanduenses da amostra (no total, são treze esses falantes).

Outro aspecto a ser observado é que a ocorrência da variante fricativa na fala de itanhanduenses não deve ser fruto apenas da classificação dos informantes em macrocategorias sociais, mas também da identidade sociolinguística que cada um, com maior ou menor nível de consciência, constrói e assume para si.

Dez dos informantes da amostra não exibem variação (pelo menos dentro nas entrevistas coletadas): pronunciam a coda (-r) sempre como retroflexo. Já os demais 26 informantes que compõem a amostra têm ocorrências de tepe e fricativo, além de retroflexo.

A seguir, esses três grupos de itanhanduenses que exibem variação na sua fala são qualitativamente analisados, com destaque para os informantes que, na Tabela 20, aparecem em negrito - por revelarem taxas de ocorrências das variantes não prototípicas mais altas que a média do grupo.

\section{Retroflexos e Tepes}

Dentro do grupo de falantes que exibem ocorrências dessas variantes, a média para o tepe é bastante baixa - 1,4 ocorrências por informante. Quatro deles se destacam, com frequências de tepe um pouco mais altas: Heloísa, Rosângela, Josué e André. Dentre eles, três pertencem ao subgrupo B, que reúne os itanhanduenses que menos se identificam - social, econômica e linguisticamente - com a cidade de Itanhandu e seus habitantes.

Entretanto, ao olhar para os demais informantes que compõem esse mesmo grupo, nota-se que eles se distribuem igualmente entre os dois grupos de identificação presentes na cidade. Viviane, Fernanda, Marcos e Augusto pertencem ao grupo de identificação A, ao passo que Cristina, Lorena, Gustavo e Ricardo são do grupo de identificação B.

Dessa maneira, pode-se afirmar que, para o conjunto de itanhanduenses que exibem pronúncias retroflexas e tepes, o grupo de fatores Identificação com a Cidade não é, sozinho, suficiente para explicar a ocorrência das pronúncias não prototípicas.

Assim como nas análises apresentadas no capítulo anterior, o grupo de fatores Tempo Fora permite melhor compreensão do fenômeno observado. Dos quatro informantes cuja taxa de tepes está acima da média em Itanhandu, 
três moraram fora da cidade (Heloísa morou cinco anos fora; André, onze; e Rosângela mora há vinte e dois anos fora).

Heloísa é uma jovem mulher. Recém-formada à época da gravação de sua entrevista, voltou de Juiz de Fora para Itanhandu porque lá estava grande parte de sua família e também porque teve uma oferta de emprego na cidade. Entretanto, a jovem almeja mudar-se novamente: ela afirma que gostaria de morar em alguma cidade do Vale do Paraíba, como São José dos Campos ou Taubaté.

Além disso, Heloísa possui alguns primos no estado de São Paulo, principalmente em cidades do ABC. Em determinado momento da entrevista, ela afirma que sua fala é "meio paulista" por possuir parentes em São Paulo ("eu falo meio paulista por causa dos meus primos serem paulistas. Querendo ou não você puxa").

As onze ocorrências de tepe na fala de tal informante parecem ser resultado da confluência de três fatos: (1) tempo de permanência fora de Itanhandu e consequente contato com outras variantes linguísticas, o que permitiu a aquisição de certa consciência linguística pela informante sobre o desprestígio do retroflexo em outras comunidades de fala; (2) presença de parentes morando na região metropolitana de São Paulo, o que a tem levado a um contato constante com a variante tepe;e (3) sua vontade de sair novamente de Itanhandu e uma possível busca de afastar-se da realidade, inclusive linguística, da cidade.

Rosângela, outra mulher que "destoa" desse subgrupo de itanhanduenses por exibir uma taxa maior de ocorrências de tepe, tem cinquenta anos e vive há vinte e dois no estado de São Paulo (morou cinco anos em Avaré e mora há dezessete em Guarulhos).

Em alguns momentos da entrevista, tal informante deixa claro que deseja fortemente não ter que voltar a viver em Itanhandu; diz que voltaria apenas para cuidar de seus pais idosos, conforme o trecho abaixo.

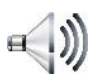

D1: você [hes.] você [hes.] gosta de morar em Guarulhos então? você pensa em voltar para cá?...

S1: não não penso não

D1: não? só em último caso

$\mathrm{S} 1$ : só em último caso de [hes.] de ter que cuidar da minha mãe ou

D1: uhum... por uma necessidade muito forte

S1: por uma necessidade

D1: entendi... 
S1: que me obrigue né? ter que voltar... (F3B_rosângela)

Para Rosângela, voltar para Itanhandu representaria um retrocesso, à semelhança do que ocorre com pessoas que saem da casa dos pais para tentar algo melhor e acabam tendo que regressar a ela.

Rosângela chega a afirmar que tentou "corrigir" seu sotaque mineiro por considerá-lo "ruim", já que, segundo ela, tal sotaque não deve ser empregado por alguém que more em São Paulo, mesmo se tratando de alguém vindo de outros lugares. Ela diz:

$\mathrm{S} 1$ : acho que até já falei mineiro um pouco mais mas [hes.]

D1: uhum

S1: hoje em dia eu falo um pouco menos mas não [hes.] não deixa

D1: uhum

S1: num [hes.]...

D1: não esquece

$\mathrm{S} 1$ : já [hes.] já [hes.] já tentei já [hes.] me corrigir mas exatamente por [hes.] estar lá por estar lá em São Paulo

D1: uhum

S1: no estado de São Paulo

D1: por que você acha que

S1: porque lá eles criticam mesmo eles falam né? você abre a boca o pessoal já fala é mineira né? [risos] então pera lá deixa eu corrigir um pouco esses negócios aqui que está ficando ruim... (F3B_rosângela)

Parece que as oito ocorrências de tepe na fala de Rosângela indicam um forte contato com essa variante, já que a informante mora atualmente na cidade de Guarulhos, e de uma grande identificação com essa metrópole, principalmente no que se refere à ideia de prosperidade e sucesso, qualidades que a informante não atribui à sua cidade natal.

Tomando cada uma das oito ocorrências de tepes na fala de Rosângela, verifica-se que seis delas foram produzidas em situação de leitura. Conforme vimos no Capítulo 4, Labov (2001) postula que são essas situações que propiciam maior monitoramento, por parte do falante, das pronúncias empregadas.

De modo semelhante a Heloísa e Rosângela, André se identifica pouco com a realidade econômica e social de Itanhandu. Ele viveu onze anos em São Paulo e resolveu que se daria um ano de férias em Itanhandu. Para ele, Itanhandu é local de lazer e descanso, mas não uma cidade para morar e construir a vida. São Paulo, por sua vez, é apontada como uma cidade estressante, mas cheia de oportunidades - e que tem mais a ver com seu estilo 
pessoal (além do fato de que suas duas irmãs também moram na capital paulista).

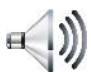

D1: mas que que tem aqui em Itanhandu que você gosta? que você resolveu voltar?

$\mathrm{S} 1:$ as amizades

D1: é?

S1: é eu sinto/ eu sentia falta assim

D1: e na cidade tem alguma coisa assim?

$\mathrm{S} 1:$ não

D1: não?

S1: não nada me atrai aqui aqui é totalmente diferente dos meus gostos assim até de balada esses negócios assim

D1: uhum

S1: não tem muito [hes.] não é muito o meu estilo assim eu não sou forrozeiro sertanejo [risos] essas coisas não curto não

D1: nessa parte você preferia São Paulo?...

S1: bem mais as baladas em São Paulo é outra coisa né? [risos] nossa tem nem comparação (M2B_andré)

Pode-se, então, entender que as onze ocorrências de tepes na entrevista com André advêm de sua forte identificação com São Paulo e dos anos que lá passou em contato direto com esta que é a variante mais frequente na cidade (OUSHIRO, 2015). Metade dessas ocorrências foram produzidas em situação de leitura.

Finalmente, Josué representa um contraponto aos três informantes acima. Trata-se de um homem da terceira faixa etária, que nunca saiu de Itanhandu e afirma identificar-se com a cidade. Como explicar, então, as sete ocorrências de tepe em sua entrevista?

Essa questão interessa particularmente na medida em que Josué chega a afirmar que as pessoas de sua idade falam o "mineiro caipirão mesmo" e que algumas pessoas mais jovens, querendo se passar por cariocas, tentam falar como eles. Além disso, ao fazer comentários sobre o sotaque paulista/paulistano, Josué diz que ele "não pega", ou melhor, que os itanhanduenses não o utilizam:

S1: o sotaque aqui é o normal do mineiro mesmo assim

D1: aham

S1: Itanhandu é bem carregadinho o pessoal gosta muito né... agora tem o [hes.] tem os carioca também né... Itanhandu também já tem os carioca tem tem muita gente... é interessante eh o sotaque tem muita gente que tem o sotaque carioca né D1: aqui em Itanhandu né? 
S1: é o paulista o outro ninguém pega né mas o carioca eu acho que eles acham lindo aqui [risos - D1] aquele negócio de arrastar né... mas eh Itanhandu tem muito [hes.] eu acho que a maioria é o caipirão mesmo

D1: entendi

S1: o mineiro caipira mesmo

D1: o resto que quer ser carioca

S1: é tem uma turma que quer ser carioca e usa esses [hes.] esses funk essas coisa

D1: aham

S1: carioca mas acho que eh [hes.] o pessoal mais velho o pessoal mais... da da da da minha turma ai mas [hes.] um pouquinho para baixo ai é mais [hes.]... mais mineiro mineiro (M3A_josué)

Entretanto, é notável que todas as sete ocorrências de tepe na entrevista com Josué foram realizadas ou na leitura da lista de palavras ou na leitura do depoimento, justamente aqueles estilos (LABOV, 2001) considerados mais monitorados. De fato, entre os quatro informantes que se destacam na presente seção, somente Heloísa não apresenta nenhuma de suas ocorrências de tepe em situação de leitura.

Ao que parece, para Josué, o retroflexo é normal e (por ele) bem avaliado na fala cotidiana, familiar e até mesmo dentro da rede de trabalho itanhanduense. Entretanto, em situações de maior formalidade, ele se adapta ao estilo correspondente, dando espaço para o tepe, variante que considera externa a Itanhandu e menos familiar e "caseira".

É importante notar que, dentre as variáveis independentes consideradas na análise de tepe e fricativo $x$ retroflexo, o estilo é apenas a quinta a ser selecionada como estatisticamente significativa para as ocorrências das variantes não-prototípicas. Entretanto, sua importância para entender as ocorrências das variantes tepe e fricativa aumenta quando são deixados de lado os informantes que produzem categoricamente a variante retroflexa.

\section{Retroflexos e Fricativos}

Entre os informantes que produzem fricativos (além de retroflexos), destacam-se Joana e Luciana - que estão entre aqueles que se identificam com Itanhandu.

Joana é uma mulher da terceira faixa etária que morou fora de Itanhandu por oito anos (cinco em Taubaté, dois em Belo Horizonte e um no Rio de Janeiro). Apesar de ter permanecido fora da cidade apenas $16 \%$ de sua vida (menos do que outros informantes da amostra), ela recebeu muita influência dos locais por onde passou, principalmente do Rio de Janeiro e de 
Belo Horizonte. Ela conta que passou grande parte de sua infância na capital fluminense (Trecho 1) e que também viveu momentos muito importantes na capital mineira (Trecho 2).

\section{Trecho 1:}

S1: eu passava muitas as férias que eu passava que eu lembro da minha infância como o pessoal daqui agora ultimamente como os meus filhos as férias que [hes.] mais passaram foi [hes.] em Ubatuba né?

D1: uhum

S1: maioria do pessoal de Itanhandu [risos] os mais comuns né?... é Ubatuba para mim era o Rio

D1: ah

S1: por causa que eu tinha parente no Rio então eu ia muito no Rio eu tinha uma tia... era irmã era solteirona assim era irmã do meu pai [risos] que ela ela le/ ela é ótima porque ela levava para o Rio assim para os lugares... dife/ todo mundo ia pro Rio ia para a praia né?

D1: uhum

S1: a gente não a gente fazia [hes.] de turista mesmo a gente ia tanto que eu conhecia tudo no Rio essas coisas de turístico eh [hes.] pão-de-açúcar

D1: uhum

S1: o [hes.] eh [hes.] o corcovado [hes.] aqueles o bondinho [risos] que ia para o pão-deaçúcar... eh [hes.] o jardim botânico parque lage... todos os lugares de turista que você possa imaginar navio

D1: uhum

S1: que eu conheci navios assim que chegava atracava no porto

D1: nossa que legal

S1: ela arranjava um jeito de ir então a gente eh [hes.] era ótimo lá porque eu lembro de coisa assim maravilhosa do Rio por isso que as minhas primas adorava aqui e eu também [risos] adorava o Rio (F3A_joana)

\section{Trecho 2:}

D1: em Belo Horizonte que que você achava interessante?...

S1: ah eu gostava do [hes.] do [hes.] naquele tempo

D1: uhum

S1: agora exatamente o oposto eu não gosto de ir loucura

D1: uhn

S1: trânsito [risos] essas coisas (mas) no começo eu gostava de tudo isso

D1: entendi

S1: naquele tempo quando era mais nova então eu gostava da... eh [hes.]... era [hes.] é cidade-barzinho né?

D1: uhn

S1: então eu gostava de fim de semana aqueles barzinhos lá [hes.] assim tudo na calçada é o movimento andar em shopping

D1: uhn

S1: essas coisas

D1: uhum

S1: que a moçada gosta

D1: que a cidade grande tem para oferecer

S1: eh [hes.] eh gostava de cinema...

D1: uhum

S1: lá eu nunca fui no teatro não eu já fui muito no teatro que teve eu morei um ano no Rio eu vivia em teatro [risos] mas logo depois que eu me formei que eu fui procurar 
emprego fui no Rio ai eu estava noiva ai depois que eu vim embora mas eu fiquei quase que um ano no Rio...

D1: uhum

S1: ai no Rio eu adorava teatro essas coisas... (F3A_joana)

Embora os trechos, sobretudo o segundo, evidenciem uma distância atitudinal entre a Joana jovem e a Joana adulta (veja-se, por exemplo, a posição dela em relação à "loucura" do trânsito nas cidades grandes), a informante demonstra ter preservado uma proximidade afetiva com Belo Horizonte, capital em que passou anos iniciais de sua vida adulta, e Rio de Janeiro, cidade em que passou grande parte de sua infância e juventude.

Juntamente a esses fatos, Joana diz acreditar que em Itanhandu se fala "caipira" e que esse jeito de se expressar é "feio". Além disso, mais da metade dos fricativos produzidos por Joana (dezoito ocorrências) ocorreram durante as leituras. Dessa forma, sua ligação afetiva com Rio de Janeiro e Belo Horizonte, sua posição negativa perante o falar itanhanduense e o estilo monitorado nas leituras parecem explicar a relativamente alta taxa de fricativos na fala de Joana.

Luciana é também uma mulher da terceira faixa etária que já morou fora de Itanhandu: viveu três anos em Três Corações (MG) e sete em São José dos Campos (SP). Na presente seção, ela se destaca porque não tem, e não teve, contato suficiente com a variante fricativa para justificar a alta frequência dessa variante em sua entrevista (70 ocorrências ao todo, o que representa aproximadamente $27 \%$ de seus dados).

Além de nunca ter morado no Rio de Janeiro, Luciana não possui parentes ou amigos mais próximos no estado fluminense. Ela afirma identificar-se fortemente com Itanhandu, com o modo de vida da cidade e com os costumes de seus habitantes.

D1: queria começar perguntando há quanto tempo você mora aqui em Itanhandu?

S1: então eu nasci aqui em Itanhandu

D1: uhum

S1: né... sou de mil novecentos e sessenta e um... e até os meus oito anos de idade

D1: uhum

S1: eu morei fora...

D1: morou fora?

S1: é

D1: onde você morou?

S1: eu morei em Três Corações

D1: uhum 
S1: depois eu morei em São José dos Campos... aos oitos anos de idade eu vim para cá D1: entendi

$\mathrm{S} 1$ : só que eu sou uma itanhanduense [risos - D1] nata

D1: $\{$ entendi\}

S1: \{amo\} Itanhandu (F3A_luciana)

Luciana conta sobre o que a faz gostar tanto de morar em Itanhandu e que "tentou" morar fora, mas comenta que sua adaptação à realidade das cidades grandes não foi boa e que, por isso, ela resolveu voltar a Itanhandu.

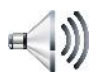

D1: hoje em dia tem alguma outra cidade que você gostaria de morar?

S1: não

D1: não?

S1: tsc quero morrer aqui...

D1: que que te faz querer ficar aqui e não querer escolher nenhuma outra cidade?

S1: nasci aqui aqui eu...

D1: entendi

S1: eu gosto desse... desse [barulho de moedas]...

D1: dessa \{vida que você leva\} aqui

S1: \{dessa vida\} que eu levo aqui

D1: entendi

S1: hoje com a idade que eu estou

D1: aham

S1: eh mas ah [hes.] apesar que que quando eu era mais moça

D1: uhum

S1: eu sempre trabalhei aqui eu nunca nunca eh eu acho que é meu mesmo

D1: entendi

S1: eu nunca tive eh

D1: vontade de sair

$\mathrm{S} 1$ : eh essa vontade de de de de procurar uma cidade maior... entendeu? não tive... $e$ tentei

D1: entendi

S1: mas não consegui ficar...

D1: você não qui/ você não quis ficar?

S1: não quis ficar

D1: onde você tentou ir?

S1: não eu tentei São José (F3A_luciana)

Todavia, apesar de reiterar sua ligação com Itanhandu e com os itanhanduenses, Luciana, ao longo da entrevista, vai revelando que muito do que compõe o "modo de vida itanhanduense" não lhe agrada. Uma característica que ela diz não apreciar é relação de amizade bastante intima que existe entre as pessoas da cidade. Ela argumenta que acha importante a hospitalidade e a amizade que caracterizam a cidade, mas, de modo decidido, diz que não é de ficar indo à casa dos outros nem de permitir que invadam sua privacidade: 
Trecho 1:

D1: você acha que o contato entre as pessoas ele é facilitado quando a cidade é menor? ou por exemplo ele é dificultado quando a cidade é maior?

S1: ah eu acho assim as pessoas [hes.] vai depende da pessoa também sabe?

D1: uhum

S1: eu acho que tem gente que fica muito de futrico

D1: uhum

$\mathrm{S} 1:$ porque cidade pequena tem isso

D1: é verdade

S1: um sabe o que passa na [hes.] né

D1: na vida do outro

S1: do outro mas hoje a vida modificou

D1: uhum

S1: hoje está tudo muito corrido... entendeu? mesmo na cidade pequena todo mundo trabalha o dia inteiro

D1: uhum

S1: chega à noite então não tem mais aquela coisa da visita da [hes.] da casa da comadre entendeu?

D1: uhum

S1: então [hes.] infelizmente eu acho que é o decorrer \{do tempo\}

D1: $\{$ mudou\}

S1: mudou muito

D1: uhum

S1: nessa parte... mas isso não me faz falta

D1: uhum

$\mathrm{S} 1$ : entendeu?

D1: entendi

$\mathrm{S} 1$ : de de estar dentro da casa \{da pessoa\}

D1: $\{$ da pessoa\}

S1: eu encontro "oh faz tempo que eu não te vejo" então eu acho que eu acho que é bom isso eu acho que é o que basta (F3A_luciana)

\section{Trecho 2:}

D1: você gosta de morar aqui?

S1: eu amo morar aqui

D1: que que faz gostar... \{daqui\} e não querer sair?

S1: \{ah eu amo\} as pessoas... eu amo sabe?

D1: uhum

S1: eu acho que [hes.] que que... eh existe um [hes.] um uma familiaridade... né conhece todo mundo

D1: uhum

S1: entendeu? não sou de ficar indo na casa das pessoas

D1: uhum

S1: assim sabe?...

D1: de frequentar

S1: de frequentar demais a casa das pessoas (não sou não) (F3A_luciana)

Durante a entrevista, Luciana assume a posição (no sentido de stance KIESLING, 2009) de uma mulher moderna e madura. Nada parece incomodála. Ela diz conviver bem com a "invasão tecnológica", não se importar com o crescimento das granjas em Itanhandu (uma vez que elas produzem empregos 
na cidade e geram renda para os itanhanduenses) nem com o crescimento dos protestantes. Forte seguidora do catolicismo, Luciana afirma que o protestantismo, ainda que em forte expansão, não alcançará o número de fiéis da doutrina religiosa que ela segue:

D1: teve... marcha para Jesus aqui em Itanhandu uma coisa assim foi... teve carreata uma coisa assim

S1: eu vi sim parece que eu vi o pessoal passar aí com (xxx)

D1: eles estão atrás

S1: é eles estão atrás (estão trabalhando) mas eu acho que esse negócio quanto à religião... eh contanto que não seja macumbaria não seja... coisa eu acho que tudo é válido

D1: entendi

S1: é um Deus só... você está entendendo?

D1: aham

S1: eh eu não mudaria a minha religião porque nasci nela nela vou morrer

D1: crê nela

$\mathrm{S} 1$ : entendeu?

D1: uhum

S1: mas não que tenha para mim alguma diferença não não tem não

D1: entendi

S1: não tem diferença nenhuma... eu acho que [hes.] até até tenho muitos alunos que são evangélicos

D1: aham

S1: e que trazem muita coisa boa para mim

D1: entendi

S1: para mim até para a minha vida

D1: pessoal

S1: é pessoal... (F3A_luciana)

O trecho a seguir também mostra o posicionamento de Luciana como uma mulher "para frente". Ela objetiva marcar sua posição como a de uma mulher que não se prende ao passado e que está sempre disposta a seguir adiante e enfrentar o desconhecido.

D1: entendi e Itanhandu de quando você era pequena e vinha de férias para agora mudou muito?

S1: ah mudou né [risos - D1] mudou um monte de coisas né a gente tem saudade... né mas a gente não pode viver de saudosismo né (F3A_luciana)

Também como um indicativo de sua "modernidade", Luciana conta que tenta manter uma relação bastante próxima com a filha, buscando ser para ela uma confidente: 
S1: você... é uma coisa que a gente tem batido muito aqui dentro da nossa casa

D1: uhum

S1: é isso... eh o diálogo de mãe e filha

D1: uhum

$\mathrm{S} 1$ : entendeu?

D1: uhum

$\mathrm{S} 1$ : então se abrir mesmo

D1: de ter esse diálogo

$\mathrm{S} 1$ : de ter esse diálogo de [hes.] e de se abrir mesmo na na/ é lógico nunca se abre totalmente

D1: é verdade

S1: né mas o máximo que pode se abrir para... para ter a mãe ali como uma apoio e não como

D1: como rival né

$\mathrm{S} 1$ : como rival para te condenar ou para te criticar ou te bater não

D1: uhum

S1: eu acho que é é uma forma de orientar trazendo... (mais próximo) da gente (F3A_luciana)

Buscando mostrar-se como alguém que aceita e valoriza as diferenças, diante de perguntas sobre os "sotaques" mineiro, carioca e paulista, Luciana reconhece distinções entre eles, mas não lhes atribui qualquer tipo de valoração negativa, mas, ao contrário, afirma que todos os sotaques são bonitos e merecem ser valorizados. Entretanto, quando se pede sua opinião sobre que sotaque é mais bonito ou de que gosta mais, Luciana não hesita em responder que seu eleito é o modo como se fala na cidade do Rio de Janeiro:

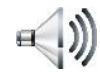

Trecho 1:

S1: ah sim sim o sotaque é uma coisa... né e acho bonito assim como a gente tem... ah eh eu acho que eu tenho a voz meia mole [risos - D1] meia... né

D1: uhum

S1: o mineiro meio "uai" né... mas é bonito eu acho bonito o carioca falar o paulistano falar eu acho [hes.] não tem

D1: qual sotaque do Brasil você mais gosta?

S1: eu acho carioca muito bonito

D1: é?

$\mathrm{S} 1: \dot{e} .$.

D1: e qual que te irrita? tem algum que te irrita?

S1: não não tem nada que me irrita não

D1: não?

S1: acho que tu/ tudo tem a sua beleza né

D1: aham

$\mathrm{S} 1$ : acho que... é porque eles veem/ vamos supor mineiro eles veem como caipira né D1: uhum

S1: e não é isso né não é por aí não... eh [hes.] eh você pega as cidades de São Paulo do interior eh [hes.] de São Paulo eles são [risos - D1] mais caipiras do que os mineiros [risos - D1] se for em termos de sotaque eles são mais caipiras

D1: aham 
$\mathrm{S} 1$ : eles falam muito mais carregado (F3A_luciana)

Trecho 2:

D1: que que você ia falar do belorizontino?

S1: Belo Horizonte tem um sotaque maravilhoso...

D1: aham...

S1: eu acho o sotaque do belorizontino maravilhoso [risos - D1] (F3A_luciana)

No fim de sua entrevista, Luciana diz que, em sua vida diária, tenta corrigir o modo como fala, buscando pronunciar as palavras "como elas realmente são".

Assim, os fatos de que nem tudo o que faz parte da realidade itanhanduense agrada Luciana; de que ela assume uma posição de mulher moderna e decidida durante a realização da entrevista, de que valoriza a variedade carioca e, finalmente, de que ela se revela como alguém que tem o costume de monitorar seus usos linguísticos fornecem, juntos, uma possivel explicação para a alta frequência da pronúncia fricativa de (-r) na fala dessa informante.

Das 70 ocorrências de tal variante na fala de Luciana, 37 são encontradas em situação de leitura, o que reitera os comentários afins na seção anterior, bem como o fato de que essa informante diz "cuidar" do modo como fala.

\section{Retroflexos, Tepes e Fricativos}

Finalmente, são quatro os informantes que se destacam entre aqueles que têm as três variantes na sua fala: Lúcia, Daniel, Humberto e Leonardo. Entre esses, três fazem parte do subgrupo de itanhanduenses que se identificam menos com a cidade.

O único informante que revela taxas de tepes e fricativos acima da média e que se identifica com a cidade e seus habitantes é Daniel. Nascido em Oliveira ${ }^{36}$, a 158 quilômetros de Belo Horizonte, Daniel foi para Itanhandu ainda criança (com 6 anos de idade). Entretanto, sua cidade natal parece ainda viver nele, em sua identidade individual e no modo como fala. Ao falar

36 Fonte: https://www.google.com.br/maps/dir/Belo+Horizonte, + MG/Oliveira+$+\mathrm{MG} / @-20.3251162,-$

$\underline{44.7106645,10 \mathrm{z} / \mathrm{data}=! 3 \mathrm{~m} 1 ! 4 \mathrm{~b} 1 ! 4 \mathrm{~m} 13 ! 4 \mathrm{~m} 12 ! 1 \mathrm{~m} 5 ! 1 \mathrm{~m} 1 ! 1 \mathrm{~s} 0 \times \mathrm{xa} 690 \mathrm{a} 165324289: 0 \times 701 \mathrm{~d}}$ $1 \mathrm{dc} 8 \mathrm{bb} 05 \mathrm{fd} 7 \mathrm{~d} ! 2 \mathrm{~m} 2 ! 1 \mathrm{~d}-43.9352376 ! 2 \mathrm{~d}-$ $19.9245018 ! 1 \mathrm{~m} 5 ! 1 \mathrm{~m} 1$ ! $1 \mathrm{~s} 0 \times a 064 \mathrm{ebd} 2 \mathrm{~b} 07 \mathrm{~b} 31: 0 \times 23 \mathrm{bf} 7 \mathrm{~b} 6 \mathrm{f} 1 \mathrm{c} 727 \mathrm{~b} 95 ! 2 \mathrm{~m} 2 ! 1 \mathrm{~d}-$ 44.8256448!2d-20.6983187 Último acesso em 08 de Junho de 2015. 
sobre nordestinos que vivem em São Paulo por muitos anos, mas não perdem seu sotaque, Daniel fala também sobre seus próprios usos linguísticos:

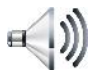

S1: porque eu vim para cá com seis anos já era para mim ter/ falar que nem o pessoal daqui

D1: uhum

$\mathrm{S} 1$ : e eu não falo [risos - S1] às vezes minhas irmã fala e eu não falo

D1: entendi... foi uma opção sua? [voz de criança ao fundo]

S1: acho que não

D1: não?

$\mathrm{S} 1$ : eu acho que seria natural [risos - S1]

D1: não?

S1: eu acho que é natural da pre/ da pessoa

D1: entendi você acha que tem a ver também com uma questão de identidade a pessoa ela... quer mostrar que ela não é dali que ela é do nordeste? você acha que tem a ver?

S1: eu acho que não

D1: não?

$\mathrm{S} 1:$ não... eu acho que para algumas pessoas sim para outras não

D1: uhum

S1: eu acho que para algumas pessoas isso aí seria... normal delas isso veio com ela é uma identidade dela não adianta ela querer mudar que ela não vai conseguir mudar D1: uhum

S1: agora outras pessoas sim acabam forçando o sotaque para mostrar que é de algum lugar (M1A_daniel)

A ocorrência de fricativos na fala de Daniel parece parte integrante de sua identidade, algo que supera sua identificação com Itanhandu e com os itanhanduenses. Afirma ele que, mesmo tentando mudá-la, "não vai conseguir". Tal identidade é muito forte e sobrevive em meio a um "mar" de retroflexos.

Já Lúcia é uma mulher de 48 anos de idade que viveu dezoito anos de sua vida fora de Itanhandu. Foram seis anos em Varginha, cidade também do Sul de Minas Gerais, e doze anos em Curvelo, município a 172 quilômetros de Belo Horizonte 37.

Ao responder à pergunta sobre a qual dos subgrupos de identificação que estratificam a amostra ela pertenceria, a informante afirma que gostaria de sair da cidade em que atualmente mora e de mudar-se para Belo Horizonte:

37 Fonte: https://www.google.com.br/maps/dir/Curvelo+-+MG/Belo+Horizonte++Minas+Gerais/@-19.3373195,-

44.7958727,9z/data $=! 3 \mathrm{~m} 1 ! 4 \mathrm{~b} 1 ! 4 \mathrm{~m} 11 ! 4 \mathrm{~m} 10 ! 1 \mathrm{~m} 5 ! 1 \mathrm{~m} 1 ! 1 \mathrm{~s} 0 \times \mathrm{xa} 87 \mathrm{~d} 533 \mathrm{f} 4 \mathrm{eb} 9 \mathrm{a} 1: 0 \times 8 \mathrm{ba} 556$ 2a80e467b6!2m2! 1d-44.4306733!2d-18.7532048!1m3!2m2!1d-43.9352685!2d19.9245192. Último acesso em 08 de Junho de 2015. 
D1: você se mudaria daqui?... tem outra cidade que você gostaria de morar?

$\mathrm{S} 1$ : não/ tem tenho vontade de ir embora para Belo Horizonte

D1: por quê? que que te atrai lá?... [sinos tocando]

S1: ah porque eu acho Itanhandu está muito parado não tem muita coisa para fazer... para a minha idade

D1: uhum

S1: não tem um cinema não tem um teatro não tem um nada então isso faz falta né (F3B_lúcia)

Em outro trecho da entrevista, Lúcia discorre sobre os motivos que a fazem preferir Belo Horizonte ao Rio de Janeiro ou a São Paulo não só para ela, mas também para seus filhos (dentre os quais, dois de fato moram na capital mineira).

S1: minhas filhas mesmo eu não quero que elas voltem de jeito nenhum

D1: porque você acha que não tem campo para elas trabalharem

$\mathrm{S} 1$ : ah não tem... tantos anos de dedicação de estudo tem que ficar para uma cidade maior

D1: uhum

S1: não São Paulo [risos - D1] mas Belo Horizonte está de bom tamanho [risos - S1, D1] que é uma cidade legal... não Belo Horizonte é um roção né é uma cidade grande mas... eu mesma conheço todos os vizinhos delas sabe? ainda tem esse contato que eu acredito que São Paulo não tenha Belo Horizonte ainda tem isso você ser [hes.] ser mineiro

D1: isso que eu ia te perguntar por que você acha que tem/consegue preservar esse contato?

$\mathrm{S} 1$ : por ser mineiro mesmo

D1: aham

S1: porque mineiro é diferente lá eu chego eu conheço todo mundo... as minhas filhas conhece todo mundo lá eh se minha filha está... com febre eu ligo para uma vizinha a vizinha larga o que está fazendo para acudir quer dizer

D1: aham

$\mathrm{S} 1$ : então continua... é coisa de mineiro mesmo sabe? que não tem isso com carioca

D1: aham

S1: São Pau/ paulista paulistano [risos - D1] não tem esse né

D1: é verdade

S1: porque a vida é mais corrida também né... nesses outros lugares (F3B_lúcia)

Considerando-se seu posicionamente, que vai desenvolvendo durante a entrevista, (inclusive o excerto (7) do Capítulo 1, em que afirma que Itanhandu não é uma cidade composta de mineiros legítimos), Lúcia dá pistas de que a "mineiridade" que ela valoriza e defende vem de Belo Horizonte e de suas características sociais, econômicas e linguísticas. 
Dessa maneira, a alta frequência da variante fricativa em sua fala é indicativa de seu orgulho de ser "mineira de Belo Horizonte". Para tal informante, a variante funciona como um indice de "mineiridade" mais forte do que a variante retroflexa.

Humberto, por sua vez, é um homem de 41 anos que já morou em diversas cidades brasileiras ao longo de doze anos (Angra dos Reis - RJ, Belo Horizonte - MG, Ponta Grossa - PR, Rio de Janeiro - RJ, Sete Lagoas - MG e Taubaté - SP).

A presença de tepes e fricativos em sua fala pode ser explicada pelo fato de que, envolvido com questões culturais e turísticas, Humberto se movimenta bastante entre Rio de Janeiro e São Paulo. Além disso, ele tem duas irmãs que moram fora de Itanhandu. Ambas migraram para São Paulo e, tempos depois, uma delas mudou-se para Angra dos Reis.

Durante a entrevista, Humberto revela vontade de mudar-se para o Rio de Janeiro. Tal desejo teria ganhado força por conta de um curso de pósgraduação que Humberto estava fazendo no Rio de Janeiro e que o obrigava a ir para lá toda semana.

D1: e por que que você escolheu morar aqui em Itanhandu?...

$\mathrm{S} 1$ : eh na verdade não é escolha [risos - S1, D1] eh hoje assim eu tenho uma (vontade) muito grande de voltar para o Rio... né eu estou fazendo um curso na Fundação Getúlio Vargas... eu tentei o mestrado por duas vezes

D1: uhum

S1: não/ uma vez na PUC e uma vez/ que é uma área que eu gosto que é geografia

D1: uhum

S1: e essa questão de desenvolvimento também né... sustentável... e [hes.] e a questão cultural... que é uma das coisas que eu sou [hes.] apaixonado é um dos grandes pilares do turismo né

D1: uhum

S1: preservação cultural... (M2B_humberto)

Segundo ele, é bastante proveitoso, principalmente em termos de atrações culturais, o tempo passado na capital fluminense:

S1: é para o Rio sim... né mas não é mais um [hes.] não é lazer né eu tento [barulho de água] forçar lazer no Rio porque eu sei que lá eu estou próximo de opções baratas

D1: uhum

$\mathrm{S} 1$ : então essa semana que passou por exemplo eu fuçando no jornal descobri que tinha uma peça de quinze reais

D1: nossa!

$\mathrm{S} 1$ : por causa da carteirinha né 
D1: uhum

$\mathrm{S1}$ : do curso... eu falei "não eu tenho que ir" né "para ver a peça quinze reais não vou" D1: uhum

$\mathrm{S} 1$ : então eu fui quinze reais não vai comprometer tanto o orçamento [risos] então assim hoje a gente vive em cima de um orçamento (M2B_humberto)

É notável o fato de que apenas uma entre oito ocorrências de tepe na fala de Humberto tenha se dado em situação de leitura, ao passo que todas as trinta duas ocorrências de fricativa foram realizadas em situação de entrevista. Ou seja, para este informante, não é o estilo que explica seus usos variáveis - o que aumenta a importância dos dois elementos apontados anteriormente, o fato de se movimentar bastante entre Rio de Janeiro e São Paulo e ter irmãs nos dois estados.

O último informante do subgrupo daqueles que se identificam menos com Itanhandu que realiza retroflexos, tepes e fricativos que se destaca é Leonardo. Trata-se de um homem da terceira faixa etária que saiu de Itanhandu quando tinha apenas vinte e dois anos de idade e que, a partir de então, só periodicamente volta a sua cidade natal.

Assim que saiu de Itanhandu, Leonardo viveu um ano em Niterói (RJ) e depois se mudou para Brasília (DF), cidade em que vive há mais de quarenta anos. Em ambas as cidades em que morou, predomina a pronúncia fricativa para o (-r) (BRANDÃO, 2008; BUENO, 2013), o que explica, em parte, o emprego de tal variante pelo informante.

Outro fato que merece destaque é a presença de familiares de Leonardo na capital fluminense. Algumas de suas irmãs moram no Rio de Janeiro e, também por isso, está em contato constante com a variante fricativa.

Além disso, Leonardo deixa clara, logo no início da entrevista, sua identificação com Brasília e afirma que, agora, Itanhandu é para pas sar férias.

D1: e não pensa em voltar para cá?

S1: não... [risos - D1]

D1: não?

S1: ah eu sou de lá

D1: aham

S1: já tenho toda a estabilidade lá aqui é bom para passar férias

D1: entendi

S1: (para a gente) descansar para você morar é lá (M3B_leonardo) (M3B_leonardo) 
$\mathrm{Na}$ vida de Leonardo, Brasília é sinônimo de conquistas. Foi na capital federal que ele conseguiu cursar a universidade e estabelecer-se como profissional "bem sucedido":

S1: minha rotina é ótima... que que eu sou lá?... eu sou psicólogo

D1: uhum

S1: né... eu lecionei treze anos na faculdade

D1: nossa!...

S1: saí em noventa... da faculdade para ficar só no meu consultório

D1: uhum...

S1: hoje eu tenho [hes.]... um consultório... pela minha formação básica eu tenho todos os meus horários fechados

D1: ai que ótimo...

$\mathrm{S} 1:$ né... sou... profissionalmente sou muito conhecido... e reconhecido

D1: uhum...

S1: então... a gente tem uma qualidade de vida... ótima (M3B_leonardo)

O contato com a variante tepe vem da época em que Leonardo disputava campeonatos no estado de São Paulo. Além disso, é fato que esse informante também tem parentes que residem no estado paulista.

S1: né então como eu tinha facilidade para jogar futebol e jogava no industrial

D1: uhum

S1: então eu conheço a região... tanto o estado do Rio o estado de São Paulo... essa região do Vale do Paraíba aí.. o sul de Minas... passaram... passaram a ser regiões comuns

D1: uhum entendi

S1: então então eu tive muito conhecimento (M3B_leonardo)

Das suas doze ocorrências de tepes, oito localizam-se na leitura da lista de palavras e do depoimento. De maneira semelhante ao que se observou para Josué, parece ocorrer com Leonardo uma adaptação ao estilo textual.

Destacou-se, ao longo da análise individual dos informantes proposta neste capítulo, que alguns elementos linguísticos e sociais, tais como o tempo de permanência do informante fora da cidade, "tomadas de posição", atitudes linguísticas em relação a determinadas variantes, adequação aos diferentes estilos textuais, são igualmente, ou mais importantes, do que a identificação (ou não) dos entrevistados com Itanhandu e com os itanhanduenses, hipótese aventada inicialmente, para a explicação da existência das pronúncias tepes e fricativas na cidade. 
A manifestação de diferentes "tomadas de posição", e sua ligação com estilos textuais que permitem maior monitoramento, é um elemento bastante importante para a compreensão do fenômeno variável observado na pequena comunidade de fala sul-mineira investigada. 


\section{Conclusão}

Ao longo desta dissertação de mestrado, buscou-se caracterizar sociolinguisticamente a comunidade de fala mineira de Itanhandu com base na análise da variável (-r). A importância do estudo de tal comunidade reside principalmente no fato de que ela constitui um contraponto à proposta de Ribeiro et al. (1977) e Zágari (2005) acerca da divisão do estado de Minas Gerais em três sub-regiões linguisticamente distintas.

A fala itanhanduense mostrou-se como um objeto de estudo relevante na problematização dos achados do Esboço de um Atlas Linguístico de Minas Gerais (RIBEIRO et al., 1977) e de Zágari (2005), na medida em que Itanhandu se localiza na região caracterizada por um "falar apaulistado" por tais autores, mas revela não apenas a variante retroflexa de (-r), mas também as variantes tepe e fricativa. Além disso, Itanhandu está em uma região geográfica que faz divisa estadual não só com São Paulo, mas também com Rio de Janeiro, estado não considerado no EALMG e por Zágari (2005) como possível influenciador do falar de tal região (RIBEIRO et al., 1977; ZÉGARI, 2005).

Um segundo elemento da relevância no estudo da fala itanhanduense foi a hipótese inicialmente aventada de que as ocorrências de (-r) tepes e fricativos observadas na cidade se explicam pelas relações que os itanhanduenses mantêm com as duas maiores metrópoles brasileiras, para onde é bastante comum sua migração.

As análises quantitativas evidenciaram que a correlação entre o grupo de fatores Identificação com a Cidade e as variantes de (-r) é bastante menos forte do que se imaginava. Em outras palavras, a divisão dos itanhanduenses em subgrupos definidos por identificação mais forte ou mais fraca com sua cidade natal mostrou-se pouco eficiente para entender a presença de tepes e fricativos na sua fala. De fato, esses dois grupos não contemplam os informantes "indecisos" ou aqueles que, por exemplo, desejam ou desejavam sair da cidade apenas por razões econômicas.

As análises aqui apresentadas sugerem que a identidade itanhanduense se constrói para além das relações identitárias com outras cidades ou com a própria Itanhandu; ela se constrói também através das diferentes experiências individuais pelas quais os itanhanduenses passam: lugares em que já moraram, a maneira como entendem a cidade de Itanhandu e a vida de seus 
habitantes, o que almejam para si, a forma como se portam diante das diferentes situações em que são postos cotidianamente em suas vidas etc.

A divisão dos itanhanduenses nos dois grupos identitários mostrou-se mais importante para a explicação das ocorrências de tepes e fricativos quando se consideraram apenas os informantes que produziam tais variantes, excluindo-se, dessa forma, aqueles cuja pronúncia de (-r) é categoriamente retroflexa (Capítulo 6).

Mesmo na análise empreendida no nível individual, foi necessário considerar alguns elementos, como tempo de permanência fora da cidade, tomada de posição e atitudes linguísticas dos informantes, bem como estilos textuais utilizados, para melhor compreender a presença dos róticos não prototípicos na comunidade investigada.

As análises quantitativas de retroflexos versus tepes e fricativos e retroflexos fortes versus (-r) retroflexos fracos revelaram que estes são fenômenos linguísticos distintos no que diz respeito à natureza da variação. Para a primeira variável, o fenômeno observado mostrou-se ser de natureza mais social: os grupos de fatores Faixa Etária e Tempo de Permanência Fora da Cidade foram os que se mostraram mais importantes para explicar a variação estudada. Já para a variável "graus de retroflexão", são linguísticos os dois grupos de fatores mais explanatórios: Classe Morfológica da Palavra com (-r) e Frequência do Item Lexical com (-r).

$\mathrm{Na}$ primeira das análises quantitativas e também na análise no nível individual, destacam-se o grupo Tempo de Permanência Fora da Cidade. Os resultados indicam que a presença das pronúncias tepe e fricativa em Itanhandu se deve a algo que se dá mais naturalmente em decorrência de um processo de acomodação linguística (GILES, 1973) pelo qual passam os itanhanduenses que vão morar em outras cidades (principalmente do estado de São Paulo e Rio de Janeiro).

É claro que tal achado não elimina casos em que o falante monitora ativamente seu próprio discurso, conforme se viu em alguns casos destacados no Capítulo 6. Em muitos momentos, objetivando marcar seu distanciamento em relação à realidade social, econômica e mesmo linguística de Itanhandu, os informantes utilizam-se das variantes não prototípicas na cidade, sobretudo a fricativa - que parece marcar, com maior clareza do que o tepe, o "não pertencimento" (ou, pelo menos, a não afiliação) dos enunciadores à comunidade. 
Muito ainda precisa ser investigado sobre a identidade itanhanduense e a forma como ela se constrói. Ela se revela como uma mescla, um encontro de experiências pessoais, relações sociais, econômicas e linguísticas de Itanhandu e dos itanhanduenses com outras cidades, mas também de relações existentes dentro da própria cidade. 


\section{Referências}

ABRAMOWICZ, L. Sociolinguistics Meets Exemplar Theory: Frequency and Recency Effects in (ing). In: Working Papers in Linguistics, Vol 13. University of Pennsylvania, 2007.

AGUILERA, V. de A. Atlas Linguístico do Paraná. Curitiba: Imprensa Oficial do Paraná, 1994.

Crenças e atitudes linguística: um estudo do português com línguas de contato. 2009. [Projeto desenvolvido pela autora].

; SILVA, H. C. Dois momentos do /-r/ retroflexo em Lavras - MG: no Atlas Linguístico de Minas Gerais e nos dados do projeto do Atlas Linguístico do Brasil. In: Revista Diadorim, UFRJ, Rio de Janeiro, 2011, v.8.

ALENCAR, M. S. M. Aspectos sócio-dialetais da lingua falada em Fortaleza: as realizações dos fonemas /r/ e /r/. Tese de doutorado. Fortaleza, Universidade Federal do Ceará, 2007.

AMARAL, A. O dialeto caipira. São Paulo: Hucitec. Secretaria de Cultura, Ciência e Tecnologia, 1976, 4. Ed.

ARAGÃO, M. S.; MENEZES, C. Atlas Lingüístico da Paraíba. João Pessoa/Brasília: UFPB/CNPQ, 1984. 2v.

BARBOSA, P. A.; ALBANO, E. C. Ilustrations of the IPA: Brazilian Portuguese. J Int Phonet Assoc, 34(2): 227-32, 2004.

BAYLEY, R. The quantitative paradigm. In: CHAMBERS, J. K.; TRUDGILL, P.; SCHILLING-ESTES, N. (Eds.), The Handbook of Language Variation and Change, pp. 117. Oxford and Malden, MA: Blackwell, 2003.

BECKER, K. / r/ and the construction of place and identity on New York City's Lower East Side. Journal of Sociolinguistics 13/5, 2009: 634-658.

BELL, A. Language style as audience design. Cambridge University Press, 1984.

BIELER, M. E. Um estudo sociolinguístico de Itanhandu. Relatório final do primeiro ano de Iniciação Científica entregue ao CNPq em Agosto de 2011.

. Um estudo sociolinguístico de Itanhandu. Relatório final de Iniciação Científica entregue à reitoria da Universidade de São Paulo em Agosto de 2012.

Boersma, Paul; Weenink, David (2015). Praat: doing phonetics by computer [Computer program]. Version 5.4.0. Último acesso em 08 de Junho de 2015. http://www.praat.org/

BOURDIEU, P; BOLTANSKI, L. Le fetichisme de la langue. Actes Rech. Sci. Soc. 1:2-32, 1975 apud ECKERT, P. Three Waves of Variation Study: The 
emergence of Meaning in the Study of Sociolinguistic Variation. Annual Review of Anthropology, 41. 87-100, 2012.

BRANDÃO, S. F. O pescador do Municipio de Campos: universo e linguagem. 490f. Tese (Doutorado em Letras Vernáculas) - Universidade Federal do Rio de Janeiro, Rio de Janeiro, 1988.

O /R/ implosivo no Norte do Estado do Rio de Janeiro. In: PEREIRA, Cilene C.; PEREIRA, Paulo R. D. (org.) Miscelânea de estudos lingüísticos e literários in memorian Celso Cunha. Rio de Janeiro: Nova Fronteira. 1995. p. 49-58.

Aspectos sociolingüísticos de um dialeto rural. In: HORA, Dermeval da (Org) Diversidade lingüistica no Brasil. João Pessoa: Idéia. 1997. p. 6169.

; MOTA, M. A.; CUNHA, C. S. Um estudo contrastivo entre o português europeu e o português do Brasil: o $-\mathrm{R}$ final de vocábulo. In: BRANDÃO, S. F.; MOTA, M. A. (Orgs.). Análise contrastiva de variedades do português: primeiros estudos. Rio de Janeiro: In-Fólio. 2003, p. 163-180.

Nas trilhas do $-\mathrm{R}$ retroflexo. Signum: Estudos Linguísticos, Londrina, 2007. n.10(2), p.265-283.

Variação em coda silábica na fala popular fluminense. Revista da ABRALIN, v. VII, 2008, p. 177-190.

; BRACONI, Clarice . Róticos em coda silábica na fala de Nova Iguaçu-RJ com base em diferentes tipos de corpus. Revista do GELNE (UFC), v. 14, p. 21-40, 2012.

BUENO, L. F. Os róticos do português falado em Brasília por crianças de 03 a 07 anos de idade. Dissertação (Mestrado em Linguística). Brasília: Universidade de Brasília, 2013.

BRESCANCINI, C.; MONARETTO, V. N. D. O. Os róticos no sul do Brasil: panorama e generalizações. Signum: Estudos Linguísticos, Londrina, 2008. n.11/2, p.51-66.

BYBEE, $J$ and HOPPER, P. Frequency and the Emergence of Linguistic Structure. Philadelphia: John Benjamins, 2001.

CALLOU, D. M. I. Variação e distribuição da vibrante na fala culta do Rio de Janeiro. Tese de Doutorado. Rio de Janeiro, Universidade Federal do Rio de Janeiro, 1979 apud REIS, M.; DIAS, A. B. B. A vibrante final de infinitivo na fala de crianças em fase final de aquisição da linguagem: o efeito cumulativo de natureza fonomorfossintática sobre o fonema /r/. Revista Virtual de Estudos da Linguagem - ReVEL. V. 4, n. 7, agosto de 2006.

Variação e distribuição da vibrante na fala urbana culta do Rio de Janeiro. Rio de Janeiro: PROED-UFRJ, 1987. 
; LEITE, Y; MORAES, J. Variação e diferenciação dialetal: a pronúncia do /r/ no português do Brasil. In: $\mathrm{KOCH}$, I. (org.). Gramática do português falado. Campinas: UNICAMP, 1996. v. 6. p. 465-493.

A realização das consoantes posvocálicas no português do Brasil, in Gramática do Português Falado. Campinas: Editora da Unicamp, 1998.

Processo(s) de enfraquecimento consonantal no português do Brasil. In: ABAURRE, B.; RODRIGUES, A. (org) Gramática do Português falado: Novos estudos descritivos. v. VIII. Campinas, UNICAMP, 2002. p. 537-556.

CAMPBELL-KIBLER, K. Accent, (ING) and the social logic of listener perceptions. American speech, 82. 2007. 32-64.

I'll be the judge of that: diversity in social perceptions of (ING). Language in Society, Cambridge, v. 37, n.5, p. 637-659, 2008.

CARDOSO, Suzana Alice Marcelino. Atlas Lingüistico de Sergipe II. Tese (Doutorado), Rio de Janeiro, Universidade Federal do Rio de Janeiro, 2002. v. 1,2 e 3.

CASEY, C. S. Postvocalic /R/ in New Orleans: Language, Place and Commodification. University of Pittsburg, 2013.

CASTRO, V. S. O r "caipira" em São Paulo: estudo com base em dados do Atlas Linguístico do Brasil (ALiB). Comunicação apresentada no SILEL, Uberlândia, 2009.

CEDERGREN, H. The interplay of social and linguistic factors in Panama. PhD thesis. Cornell Univ. Ling. Dep. 1973, 324 pp apud ECKERT, P. Three Waves of Variation Study: The emergence of Meaning in the Study of Sociolinguistic Variation. Annual Review of Anthropology, 41. 87-100, 2012.

CHAMBERS, J. K. "Patterns of Variation incluing Change". In.: Chambers, J. K.; Trudgill, P.; Schilling- Estes, N. The Handbook of Language Variation and Change. Malden / Oxford / Carlton; Blackweel, 2003.

COELHO, R. F. É nóis na fita! Duas variáveis linguísticas numa vizinhança de periferia paulistana. (O pronome de primeira pessoa do plural e a marcação do plural no verbo). Mestrado em Linguística. Universidade de São Paulo (USP). Agosto de 2006.

CRUZ, M. L. C. Atlas lingüístico do Amazonas. Tese (Doutorado em Letras) Universidade Federal do Rio de Janeiro, Rio de Janeiro, 2004. 2v.

DAHAN, J. et al. Time Course of Frequency Effects in Spoken-Word Recognition: Evidence from Eye Movements. Cognitive Psychology 42: 317367, 2001.

DELATTRE, P; FREEMAN, D. A dialect study of American r's by x-ray motion picture. Linguistics, 44,1968, p. 29-68. 
DINKIN, A. The effect of word frequency on F2 of short vowels in American English. Ms., University of Pennsylvania. 2004.

The Real Effect of Word Frequency on Phonetic Variation. Paper presented at PLC 31, University of Pennsylvania. 2007.

DURANTI, A. Linguistic anthropology: history, ideas, issues. In: DURANTI, A. (Ed.). Linguistic anthropology: a reader. Oxford: Blackwell, 2001. p. 01-60.

ECKERT, P. Variation and the indexical field. Journal of Sociolinguistics. 12: 453-76, 2008.

Affect, sound symbolism, and variation. Penn working papers in linguistics. 16.1. 2010.

Three Waves of Variation Study: The emergence of Meaning in the Study of Sociolinguistic Variation. Annual Review of Anthropology, 41. 87$100,2012$.

ENTRIKIN, J. N. Comtemporary Humanism in Geography. Annals of the Association of American Geographers, 66: 615-632, 1976 apud JOHNSTONE, B. Place, Globalization, and Linguistic Variation. In Fought, C. (ed.) Sociolinguistic Variation: Critical Reflections. New York: Oxford University Press: 65-83, 2004.

FERRAZ, I. S. Caracteristicas fonético-acústicas do /r/ retroflexo do português brasileiro: dados de informantes de Pato Branco (PR). Dissertação de Mestrado. Curitiba: Universidade Federal do Paraná, 2005.

FERREIRA, Carlota; MOTA, Jacyra; FREITAS, Judith; ANDRADE, Nadja; CARDOSO, Suzana; ROLLEMBERG, Vera; ROSSI, Nelson. Atlas Linguiistico de Sergipe (ALS). Salvador: UFBA-FUNDESC, 1987.

FLEMMING, E. Auditory representations in phonology. New York: Routledge, 2002.

GILES, H. Towards a theory of interpersonal accommodation through language: some canadian data. Language in society, v. 2, n. 2. P. 177-192. 1973.

GOLDINGER, S. Words and voices: Episodic traces in spoken word identification and recognition memory. Journal of Experimental Psychology 22: 1166-1183, 1996.

GOMES DA SILVA, F. Alagoanos em São Paulo e a Concordância Nominal de Número. Dissertação (Metrado em Linguística). Faculdade de Filosofia, Letras e Ciências Humanas, Universidade de São Paulo - USP, 2014.

GRECIO, F. N. Variantes do " $r$ " em posição de coda silábica: um estudo fonético-acústico. Revista Intercâmbio, v. XXVI: 80-94, 2012. São Paulo: LAEL/PUCSP. ISSN 2237-759x 
GUY, G. R. Introdução à análise quanitativa da variação linguística. 1993. Tradução de Ana M. S. Zilles e Leonardo Z. Maya. In: GUY, Gregory; ZILLES, Ana. Sociolinguistica quantitativa: instrumental de análise. São Paulo: Parábola Editorial, 2007.

Varbrul: análise avançada. Tradução de Ana M. S. Zilles e Leonardo Z. Maya, 1988. In: GUY, Gregory; ZILLES, Ana. Sociolinguística quantitativa: instrumental de análise. São Paulo: Parábola Editorial, 2007.

; ZILLES, Ana. Sociolinguística quantitativa: instrumental de análise. São Paulo: Parábola Editorial, 2007.

HAGIWARA, R. Acoustic realizations of American / $\mathrm{r} /$ as produced by women and men. UCLA Working Papers in Phonetics, nº 90, agosto de 1995.

HEBDIGE D. Subculture: The Meaning of Style. New York: Methuen, 1984 apud ECKERT, P. Three Waves of Variation Study: The emergence of Meaning in the Study of Sociolinguistic Variation. Annual Review of Anthropology, 41. 87-100, 2012.

HOLMES, J. Setting new standards: sound changes and gender in New Zealand English. English World-Wide (18): 107-42. 1997.

HUME, E.; JOHNSON, K (eds.). The role of speech perception in phonology. San Diego: Academic Press, 2001.

IBGE

<http://www.ibge.gov.br/cidadesat/painel/painel.php?codmun=313310\&sear ch=minas-gerais $\mid$ itanhandu\#historico> Acesso em 08 de Junho de 2014.

IRVINE, J. T. "Style" as distinctiveness: the culture and ideology of linguistic differentiation. In: ECKERT, P. and RICKFORD, J. R. (eds.) Style and Sociolinguistic Variation. Cambridge University Press, 2001.

JAKOBSON, R; FANT, G; HALLE, M. Preliminaries to speech analysis. Cambridge, MA, MIT press, 1952.

JOHNSTONE, B. Place, Globalization, and Linguistic Variation. In Fought, C. (ed.) Sociolinguistic Variation: Critical Reflections. New York: Oxford University Press: 65-83, 2004.

JURAFKKY, D. et al. Probabilistic Relations between Words: Evidence from Reduction in Lexical Production. In: Frequency and the Emergence of Linguistic Structure, ed. J. Bybee and P. Hopper, 2000. p. 229-280. Philadelphia: John Benjamins.

KENT, R. D.; READ, C. The acoustic characteristics of consonant. In: KENT, R. D.; READ, C. The acoustic analysis of speech. London - San Diego: Whurr Publishers - Singular Publishing Group, 1992 apud GRECIO, F. N. Variantes do "r" em posição de coda silábica: um estudo fonético-acústico. Revista Intercâmbio, v. XXVI: 80-94, 2012. São Paulo: LAEL/PUCSP. ISSN 2237$759 x$ 
KIESLING, S. F. Style as Stance: Stance as the Explanation for Patterns of Sociolinguistic Variation. In: JAFFE, A. Stance: Sociolinguistic Perspectives. New York: Oxford University Press, 2009.

KOCH, W.; KLASSMAN, M. S.; ALTENHOFEN, C. V. Atlas LingüisticoEtnogáfico da Região Sul do Brasil (ALERS). Vol. 1 Introdução; Vol. 2, Cartas Fonéticas e Morfossintáticas. Porto Alegre/ Florianópolis / Curitiba: Ed. UFRGS/ Ed. UFSC/ Ed. UFPR, 2002.

LABOV, W. The social motivation of a sound change. Word (19): 273-309, 1963.

The social stratification of English in New York City. São Paulo: Cambridge University Press, 1966.

Press, 1972.

Sociolinguistic Patterns. Philadelphia: University of Pennsylvania

Some principles of linguistic methodology. Language and Society 1: 97-120, 1972b.

Principles of linguistic change: Internal factors, v.1. Oxford: Blackwell, 1994.

Principles of Linguistic Change: external factors. Oxford \& Cambridge: Blackwell, 2001.

Tha anatomy of style-shifting. In: ECKERT, P. and RICKFORD, J. R. (eds.) Style and Sociolinguistic Variation. Cambridge University Press, 2001.

Words floating on the surface of sound change. Paper presented at NWAV 32, University of Pennsylvania. 2003.

The Social Stratification of English in New York City. São Paulo/Cambridge: Cambridge University Press. Second Edition, 2006.

A motivação social de uma mudança Sonora. In: Padrões Sociolinguísticos. Tradução: Marcos Bagno, Maria Marta Pereira Scherre, Caroline Rodrigues Cardoso. São Paulo, Parábola Editorial, 2008 [1963].

Principles of linguistic change: Cognitive and cultural factors, v. 3. Oxford: Wiley-Blackwell, 2010.

LACY, P. de. Markedness: Reduction and preservation in phonology. Cambridge, CUP, 2006.

LADEFOGED, P.; MADDIENSON, I. The sounds of the world's languages. Cambridge: Blackwell, 1996: 215-245.

LAVANDERA, B. Where does the sociolinguistic variable stop?. Language in Society, vol. 7, 171-182, 1978.

LEHISTE, I. Acoustical characteristics os selected English consonants. The Hague: Mouton, 1962: 51-115. 
LEITE, C. M. B. Atitudes Linguisticas: A Variante Retroflexa em Foco. 150 p. Dissertação (Mestrado em Linguística). Instituto de Estudos da Linguagem, Universidade Estadual de Campinas - UNICAMP, Campinas, 2004.

O / R/ em posição de coda silábica no falar campineiro. 201 p. Tese (Doutorado em Linguística). Instituto de Estudos da Linguagem, Universidade Estadual de Campinas - UNICAMP, Campinas, 2010.

LIMA, Luciana Gomes de. Atlas Fonético do entorno da Baía de Guanabara - AFeBG. 415f. Dissertação (Mestrado em Língua Portuguesa) - Universidade Federal do Rio de Janeiro, Rio de Janeiro, 2006. 2 v.

LINDAU, M. The story of $/ \mathrm{r} /$, in Victoria Fromkin (org), V. Phonetic Linguistics: Essays in Honor of Peter Ladefoged (edited by Victoria Fromkin). New York: Academic Press, 1985, pp. 157-168.

LOURDES, R. L. DE.; ANTUNES, L. B. A produção do / r/ retroflexo no falar de Patos de Minas. Publicado no XIX SIC - UFOP. 2011. Resumo do trabalho disponivel em: http://www.sic.ufop.br/anais/exibir_trabalho/1348. Último acesso em 08 de Junho de 2015.

MACAULAY, R. K. S. Language, Social Class and Education: A Glasgow Study. Edinburgh: Univ. Edinb. Press, 1977 apud ECKERT, P. Three Waves of Variation Study: The emergence of Meaning in the Study of Sociolinguistic Variation. Annual Review of Anthropology, 41. 87-100, 2012.

MAIA, E. M. No reino da fala: a linguagem e seus sons. São Paulo: Ática, 1985 apud FERRAZ, I. S. Características fonético-acústicas do /r/ retroflexo do português brasileiro: dados de informantes de Pato Branco (PR). Dissertação de Mestrado. Curitiba: Universidade Federal do Paraná, 2005.

MARTINS, Edson Ferreira. Atlas lingüístico do Estado de Minas Gerais: o principio da uniformidade da mudança lingüística nas características fonéticas do português mineiro. In: Revista Virtual de Estudos da Linguagem - ReVEL. V. 4, n. 7, agosto de 2006. ISSN 1678-8931 [www.revel.inf.br].

McDAVID, R. Postvocalic /-r/ in South Carolina: A social analysis. American Speech, 23,194-203, 1948 apud CASEY, C. S. Postvocalic /R/ in New Orleans: Language, Place and Commodification. University of Pittsburg, 2013.

MELO, G. C. A língua do Brasil. 3. ed. Rio de Janeiro: Fundação Getúlio Vargas, 1975.

MELLO, H. Os corpora orais e o C-ORAL-BRASIL. In: RASO, T.; MELLO, H. (orgs.) C-ORAL-BRASIL I: Corpus de referência do português falado informal. 2012. Disponivel em: http://www.c-oral-brasil.org/ Último acesso em 08 de Junho de 2015.

MENDES, R. B. Sounding Paulistano: Variation and Correlation in São Paulo. Trabalho apresentado no NWAV39. 2010. 
Paulo Portuguese. Trabalho apresentado no VaLP2011 - Chester, Inglaterra, $2011 b$.

Percepções sociolinguísticas sobre as variantes tepe e retroflexa na cidade de São Paulo. In: HORA, D.; D.; NEGRÃO, E.V. (orgs.) Estudos da Linguagem: Casamento entre temas e perspectivas. João Pessoa: Ideia. 2012. p. 262-281.

São Paulo, 56 (3): 973-1001, 2012.

O paulistano no mapa sociolinguístico brasileiro. Alfa,

MENDOZA-DENTON, N. Language and Identity. In.: Chambers, J. K.; Trudgill, P.; Schilling- Estes, N. The Handbook of Language, Variation and Change. Malden / Oxford / Carlton; Blackweel, 2002.

MILROY, L. Language and Social Networks. Oxford: Blackwell, 1980.

MODARESSI, Y. A sociolinguistic analysis of modern Persian. PhD thesis. Univ. Kansas. 1978. $257 \mathrm{pp}$ apud ECKERT, P. Three Waves of Variation Study: The emergence of Meaning in the Study of Sociolinguistic Variation. Annual Review of Anthropology, 41. 87-100, 2012.

MOLliCA, M. C. (Org.). Aquisição de padrões fonológicos variáveis. Rio de Janeiro: Tempo Brasileiro, 1997.

MONARETTO, V. N. O. Um reestudo da vibrante: análise variacionista e fonológica. Tese de doutorado. Porto Alegre, PUCRS, 1997.

A vibrante pós-vocálica em Porto Alegre. In: BISOL, L.; BRESCANCINI, C. Fonologia e Variação: recortes do português brasileiro. Porto Alegre: EDIPUCRS, 2002.

. Descrição da vibrante no português do sul do Brasil. In: BISOL, L; COLlisCHONN, G. (Orgs.). Português do sul do Brasil: variação fonológica. Porto Alegre: EdiPUCRS, 2009.

BOURDIEU, P. A economia das trocas linguísticas - O que falar quer dizer. São Paulo: Edusp, 1998 apud MORATO, E.; BENTES, A. C. Das intervenções de Bourdieu no campo da linguística: reflexões sobre competência e língua legitima. Horizontes, Bragança Paulista, v. 20, p. 31-48, jan./dez. 2002. Disponivel em: projetonoisnafita.vl1.net2.com.br/site/pdf/rev06.pdf. Último acesso em 09/12/2014.

MONGUILHOTT, I. O. S. A influência da etnia na vibrante catarinense. In: SEMINÁRIO DE INICIAÇÃO CIENTÍFICA DA UFSC, 8. Anais do VIII Seminário de Iniciação Científica da UFSC: cadernos de resumos. Florianópolis: Imprensa Universitária, 1998. p. 330.

A variação na vibrante florianopolitana: um estudo sóciogeolinguístico. Revista da ABRALIN, v.6, n.1, p. 147-169, jan./jun. 2007. 
MORATO, E.; BENTES, A. C. Das intervenções de Bourdieu no campo da linguistica: reflexões sobre competência e língua legítima. Horizontes, Bragança Paulista, v. 20, p. 31-48, jan./dez. 2002. Disponível em: projetonoisnafita.vl1.net2.com.br/site/pdf/rev06.pdf Último acesso em $09 / 12 / 2014$.

NARO, A. J. Modelos quantitativos e tratamento estatístico. In: Mollica (org.), Introdução à Sociolingüistica variacionista. Rio de Janeiro, UFRJ, 1992.

; SCHERRE, M. M. P. Sobre as origens do português brasileiro -

retrospectiva de um garimpo. 2004. (Apresentação de Trabalho/Comunicação).

NASCENTES, A. O linguajar carioca, $2^{\text {a }}$ edição. Rio de Janeiro: Simões, 1953.

Bases para a elaboração do Atlas Lingüistico do Brasil. Rio

de Janeiro: Casa de Rui Barbosa, 1958.

NASCIMENTO, I. B. do. O uso variável do pronome de segunda pessoa você(s)/cê(s) na cidade de São Paulo. Dissertação de mestrado. Universidade de São Paulo, São Paulo, 2010.

OLIVEIRA, Dercir. Pedro de (Org.) ._ALMS - Atlas Lingüístico de Mato Grosso do Sul._1. ed. Campo Grande: Editora UFMS, 2007. 271 p.

OUSHIRO, LIVIA. Uma análise variacionista para as Interrogativas-Q. Dissertação (Mestrado em Letras). São Paulo, Universidade de São Paulo, FFLCH, 2011.

; MENDES, R. B. A pronúncia de (-R) em coda silábica no português paulistano. Revista do GEL. São Paulo, v.8, n.2, p. 66-95, 2013 [2011].

Tratamento de dados com o $\mathrm{R}$ para análises sociolinguísticas, p.134-177. In Raquel Meister Ko. Freitag (Organizadora). Metodologia de Coleta e Manipulação de Dados em Sociolinguística, São Paulo: Editora Edgard Blücher, 2014.

http://dx.doi.org/10.5151/BlucherOA-MCMDS-10cap

Identidade na pluralidade: avaliação, produção e percepção linguística na cidade de São Paulo. Tese (Doutorado em Linguística). São Paulo, Universidade de São Paulo, FFLCH. 2015.

PAES, M. H. S. A variável (R) em coda silábica medial no Bairro Várzea, em Lagoa Santa/MG. Dissertação de mestrado. Universidade Federal de Minas Ferais (UFMG). 2014.

PEREIRA, Maria das Neves. Atlas Geolingüístico do Litoral PotiguarALiPTG. Tese (Doutorado em Letras) - Universidade Federal do Rio de Janeiro, Rio de Janeiro, 2007.

PIERREHUMBERT, J. Exemplar dynamics: Word frequency, lenition and contrast. In: Frequency and the Emergence of Linguistic Structure, ed. J. Bybee and P. Hopper, 2001a. p. 123-136. Philadelphia: John Benjamis. 
2002b.

Word-specific phonetics. Ms., Northwestern University,

PRINCE, A.; SMOLENSKY, P. Optimality Theory: Constraint interaction in generative grammar. Rutgers Optimality Archive 537, http://ling.rutgers.edu/, 1993.

RAZKY, A. et al. Atlas Lingüístico Sonoro do Pará (ALISPA). Belém: CAPES/UFPA/UTM, 2004.

REIS, M.; DIAS, A. B. B. A vibrante final de infinitivo na fala de crianças em fase final de aquisição da linguagem: o efeito cumulativo de natureza fonomorfossintática sobre o fonema /r/. Revista Virtual de Estudos da Linguagem - ReVEL. V. 4, n. 7, agosto de 2006.

RIBEIRO, J. ; ZÁGARI, M. R. L.; PASSINI, J.; GAIO, A. Esboço de um Atlas Lingüístico de Minas Gerais - v. $1,1^{\text {a }}$ ed. Rio de Janeiro: Fundação Casa de Rui Barbosa, 1977.

ROBINSON, J.; LAWRENCE, H.; TAGLIAMONTE, S. GoldVarb: A multivariate analysis application for Windows. 2001. Disponivel em <http:// privatewww.essex.ac.uk/ patrickp/lg654/GoldVarb2001forPCmanual .htm>. Acesso em 08 de Junho de 2015.

ROMAINE, S. Postvocalic /r/ in Scottish English. In: Peter Trudgill (ed.), Sociolinguistic Patterns in British English. London: Edward Arnold. 1978 apud CHAMBERS, J. K. "Patterns of Variation incluing Change". In.: Chambers, J. K.; Trudgill, P.; Schilling- Estes, N. The Handbook of Language Variation and Change. Malden / Oxford / Carlton; Blackweel, 2003.

ROSSI, N et al. Atlas Prévio dos Falares Baianos. Rio de Janeiro: Ministério de Educação e Cultura - Instituto Nacional do Livro, 1963.

N. Variação diatópica e sociolinguística. Congresso de Sócio-eEtnolinguística, 2./Anais.../Niterói, Universidade Federal Fluminense. p. 101 $-115)$.

SANKOFF, D.; TAGLIAMONTE, S.; SMITH, E. Goldvarb X: A variable rule application for Macintosh and Windows. Department of Linguistics, University of Toronto, 2005.

SANTOS, W. S. A morfologia do indicativo na expressão do subjuntivo em São Paulo e São Luís. Projeto de mestrado apresentado ao Departamento de Linguística da Universidade de São Paulo. 2012.

SCHERRE, M. M. P. Paralelismo lingüístico. Estudos da Linguagem, Belo Horizonte 7/2:9-28, 1998.

Vernacular features in written language: variable use of the imperative form in Brazilian Portuguese. 2007. (Apresentação de Trabalho/Seminário).

NARO, A. J.; C. R. CARDOSO. O Papel do Tipo de Verbo na Concordância Verbal no Português Brasileiro. Revista Delta, 23:esp., 2007: 283-317. 
SILVA, A. H. P. Para a descrição fonética-acústica das líquidas no português brasileiro: dados de um informante paulistano. Dissertação em Linguística. Campinas: UNICAMP, 1996.

SILVA, E. V. Norma, variação e ensino: a concordância verbal. Cadernos de Letras da UFF - Dossiê: Literatura, língua e identidade, no 34, p. 31-41, 2008.

SILVA NETO, S. da. Introdução ao estudo da lingua portuguesa no Brasil, $2^{a}$ edição. Rio de Janeiro: Instituto Nacional do Livro, 1963.

SILVA, T. C. Fonética e fonologia do português brasileiro: roteiro de estudos e guia de exercícios. São Paulo: Contexto, 2002.

SILVERSTEIN, M. Indexical order and the dialectics of sociolinguistic life. Lang. Commun. 23: 193-229, 2003.

SORIANO, L. G. M. Percepções sociolinguísticas do /-r/ em São Paulo. Projeto de mestrado apresentado ao Departamento de Linguística da Universidade de São Paulo. 2014.

SOUZA, P. C.; SANTOS, R. S. Fonologia. In: FIORIN, J. L. (Org.). Introdução à linguística: II. Principios de análise. Capítulo de livro. p. 33-58. $4^{\mathrm{a}}$ ed. $1^{\mathrm{a}}$ reimpressão - São Paulo: Contexto, 2007.

STERIADE, D. Directional asymmetries in place assimilation: A perceptual account. In: HUME, E.; JOHNSON, K. (eds.). The role of speech perception in phonology. New York: Academic Press, 2001, p. 50-219.

TRUDGILL, P. The Social Differentiation of English in Norwich. Cambridge, UK: Cambridge Univ. Press, 1974 apud ECKERT, P. Three Waves of Variation Study: The emergence of Meaning in the Study of Sociolinguistic Variation. Annual Review of Anthropology, 41. 87-100, 2012.

TUAN, YI-FU. Space and Place: Humanistic Perspective. Progress in Geography: 6: 213-252, 1974 apud JOHNSTONE, B. Place, Globalization, and Linguistic Variation. In Fought, C. (ed.) Sociolinguistic Variation: Critical Reflections. New York: Oxford University Press: 65-83, 2004.

VIEIRA, M. S. Aí, dai e então como articuladores de orações em Campo Grande (MS) e São Paulo (SP). Projeto de doutorado apresentado ao Departamento de Linguística da Universidade de São Paulo. 2012.

VOTRE, S. J. Aspectos da variação fonológica na fala do Rio de Janeiro. Tese de doutorado. Rio de Janeiro: Pontíficia Universidade Católica do Rio de Janeiro, 1978 apud REIS, M.; DIAS, A. B. B. A vibrante final de infinitivo na fala de crianças em fase final de aquisição da linguagem: o efeito cumulativo de natureza fonomorfossintática sobre o fonema /r/. Revista Virtual de Estudos da Linguagem - ReVEL. V. 4, n. 7, agosto de 2006.

WALKER, J. A. Form, function, and frequency in phonological variation. Language Variation and Change, 24, pp 397-415. doi:10.1017/S0954394512000142. 2012. 
WEINREICH, U., LABOV, W.; HERZOG, M. I. Fundamentos empiricos para uma teoria da mudança linguística. Tradução: Marcos Bagno. São Paulo: Parábola Editorial, 2006.

WOLFRAM, W. A Sociolinguistic Description of Detroit Negro Speech. Washington, DC: Cent. Appl. Ling. 1969 apud ECKERT, P. Three Waves of Variation Study: The emergence of Meaning in the Study of Sociolinguistic Variation. Annual Review of Anthropology, 41. 87-100, 2012.

ZÁGARI, M. R. L. Esboço de um Atlas Linguístico de Minas Gerais. In: Socorro A. M. Cardoso (org.). Caminhos e perspectivas para a Geolinguística no Brasil. Seminário realizado na UFBA em novembro de 1996.

Os Falares Mineiros: Esboço de um Atlas Lingüístico de Minas Gerais. In: Vanderci de Andrade Aguilera. (org.). A Geolingüística no Brasil trilhas seguidas, caminhos a percorrer. 1 ed. Londrina: Editora da Universidade Estadual de Londrina, v. 1, p. 45-72, 2005. 


\section{ANEXO I}

\section{Roteiro da entrevista:}

CIDADE (aproximadamente 10 minutos)

Objetivos: descobrir o "grau de enraizamento" do informante na cidade onde vive/outras cidades; descobrir o "grau de mobilidade" da pessoa.

1. Há quanto tempo você mora em (Itanhandu/outra cidade para qual o informante se mudou e por quanto tempo morou em Itanhandu)? 2. Você gosta de morar aqui? (Se a resposta for negativa, perguntar por que não gosta, quais são os motivos que causam essa falta de empatia; se a resposta for positiva, perguntar quais as características da cidade que fazem com que o informante queira ficar.)

3. Por que você escolheu morar nesta cidade? (manter em mente que o informante pode não ter "escolhido" morar ali: pode ter sido porque a família já morava lá etc.)

a. Se o informante mora há bastante tempo: Como era a cidade antes/quando você se mudou para cá? Mudou muito?

b. Se o informante já não mora lá há muito tempo, ou se nem sempre viveu ali: Em que outros lugares você já morou? Como era lá comparado com essa cidade aqui? Onde você preferia morar?

c. Se foi a família do informante que escolheu morar ali... Quais as características da cidade que você acha que atraíram seus antepassados?

4. Você tem bastante contato com as pessoas aqui da cidade?

5. Hoje, tem alguma outra cidade em que você gostaria de morar?

INFÂNCIA (aproximadamente 5 minutos)

Objetivos: relaxar o informante (em geral, as pessoas gostam de falar de sua infância); obter informações sobre mudanças na cidade de Itanhandu; grau de mobilidade do informante; obter informações sobre escolaridade.

6. E como foi a sua infância em Itanhandu (Se o informante veio pequeno para Itanhandu perguntar os motivos que levaram sua familia a mudar-se para essa cidade)? Você pode contar um pouco de como foi, o que você fazia...? 
a. brincava na rua/dentro de casa? Do que vocês brincavam?

b. como eram os seus pais? eram rígidos...?

c. você costumava brincar com primos ou parentes que não moravam em Itanhandu (verificar de onde vinham esses parentes)?

7. Você foi pra escola na mesma cidade? Como era a escola? Você sempre estudou na mesma escola? Você gostava de ir pra escola? Tem algum professor que te marcou? Até que série você estudou?

8. Enquanto ainda era criança/adolescente, você ia pra outros lugares dentro da região (trata-se da região do sul de Minas)? (pra onde, pra fazer o quê...)

FAMÍLIA (aproximadamente 5 minutos)

Objetivos: obter informações sobre rede social do informante, grau de enraizamento na cidade.

9. Você tem irmãos? (é possivel que esta informação já tenha aparecido na parte sobre infância; neste caso, falar: "Você disse que tem uma irmã... Você tem outros irmãos?”) Quantos anos eles têm?

10. Seus pais são daqui de Itanhandu mesmo? (Se sim, perguntar também sobre avós, bisavós... até encontrar a primeira geração da família que veio para cá). Quantos anos eles (pais) têm? Quando e por que seus (pais/avós/bisavós) vieram para Itanhandu?

11. Você tem filhos? Quantos anos eles tem?

12. E o resto da família, tios, primos, também vivem aqui em Itanhandu? (Se sim, em que bairros? Moram próximo? Se não, onde? Tem contato sempre?)

TRABALHO/OCUPAÇÃO (aproximadamente 5 minutos)

Objetivos: obter informações sobre rede social do informante; características socioeconômicas.

13. Você trabalha aqui em Itanhandu? (se não souber onde a pessoa trabalha) Para casos em que o informante trabalha em cidades vizinhas: Por que você teve que sair da sua cidade para ir em busca de serviço?

14. O que você faz? Você pode me explicar um pouco?

15. Você gosta do seu serviço? (Se não, o que a pessoa preferiria fazer?) 
LAZER (aproximadamente 5 minutos)

Objetivos: obter informações sobre rede social do informante; mobilidade na cidade; características socioeconômicas.

16. E nas horas de lazer, o que você e sua família gostam de fazer? (Se saem, vão para que lugares?) Você acha que a cidade de Itanhandu tem boas opções de lazer? Quais? (Se a resposta for negativa descobrir o que falta na cidade que faz com que seus moradores procurem lazer fora dela).

17. A maioria dos seus amigos mora aqui nessa cidade mesmo? (Se não, onde?)

18. Você tem alguma atividade de recreação em grupo, algum clube...? Você exercita alguma prática religiosa? (Característica comum no interior, verificar a veracidade desse pressuposto e importância desse fator na vida das pessoas interioranas).

19. Quais são seus amigos mais antigos? Você mantém contato com os amigos de colégio? Eles continuam morando em Itanhandu?

20. Você costuma viajar? Para que lugares já viajou? O que você conheceu/viveu de mais interessante e marcante nesses lugares? Que lugares gostaria de conhecer?

A CIDADE DE ITANHANDU (aproximadamente 20 minutos)

21. Uma pesquisa recente feita em uma cidade grande mostrou que $57 \%$ das pessoas deixariam a cidade pesquisada caso pudessem. O que você acha disso? (se o informante perguntar, a pesquisa é do Ibope, foi publicada em janeiro/2010 e se referia a São Paulo) Quais motivos você acha que influenciam o desejo das pessoas de sair da grande cidade?

22. Você gosta de morar em Itanhandu? (Se não, em que lugar preferiria morar?) Por quê?

23. O que você acha que caracteriza a cidade (tanto as coisas boas quanto ruins)?

24. O que você acha que caracteriza o itanhanduense (tanto as coisas boas quanto ruins)?

25. Se você me visse pela primeira vez, você diria que eu sou itanhanduense? Por quê?

26. O que você mais gosta em Itanhandu? 
27. O que você não gosta em Itanhandu? (a depender do tópico mencionado pelo informante - falta de emprego, monotonia, saúde pública, administração da cidade etc. - procurar explorar mais o assunto. Por exemplo: você já foi sofreu com a falta de empregos? Como isso te afetou? (para obter narrativa pessoal) O que o governo e mais especificamente a prefeitura poderia fazer pra solucionar esse problema? (para obter uma fala mais distanciada).

a. Você sofre muito com o cheiro das granjas? Você sofreu com a imensa quantidade de moscas advindas do mau manejo das fezes das galinhas ou mesmo ocasionadas pelo mau cheiro das galinhas mortas? (buscando narrativa pessoal)

b. O que você acha que a prefeitura e a administração das granjas deveriam fazer para acabar com o mau cheiro? Quais medidas você acha que foram tomadas para que diminuísse o número de moscas na cidade? (buscando tom distanciado) (explorar o subtópico por aproximadamente 10 minutos)

28. Paras pessoas que não vivem em cidades interioranas, como você acha que elas imaginam que sejam essas cidades? Qual é a imagem que pessoas de fora de cidades pequenas têm desse tipo de cidade?

29. Você falou que já foi pra (X, Y, Z). Quando você foi pra esses lugares, as pessoas percebiam que você era itanhanduense, ou melhor, que você era mineiro? (Se sim, como elas percebiam?)

30. Quando você conhece alguém, você percebe se a pessoa não é daqui de Itanhandu?

a. Se sim, como você percebe? (Se o informante mencionar o modo de falar, seguir nessa linha e tentar conseguir informações mais precisas. É normal as pessoas não saberem definir o porquê, mas dá pra tentar tirar mais informações).

b. Se não: quando você ouve uma pessoa falando, por exemplo, você percebe que ela é de fora pelo sotaque?

PRODUÇÃO/PERCEPÇÃO/AVALIAÇÃO LINGUÍSTICA (aproximadamente 10 minutos)

31. Já que a gente tá falando de sotaque... qual o sotaque do Brasil que você mais gosta? E tem algum que te irrita? Como é que (o 
gaúcho/o carioca/o paulistano/o caipira etc. - a depender dos sotaques mencionados) fala $(\mathrm{m})$ ?

32. Aqui em Itanhandu tem muita gente de fora que veio morar aqui, né? (Perguntar ao informante se ela sabe de pessoas nessas condições) De onde vêm a maioria das pessoas? Quais motivos, na sua opinião, fizeram com que essas pessoas escolhessem Itanhandu para morar?

33. E como é que as pessoas falam na cidade de Itanhandu? (evitar usar a palavra "sotaque")

34. E aqui dentro do sul de Minas... você vê diferenças entre as diferentes regiões, diferentes cidades? (Se sim) Você poderia dar alguns exemplos? (É normal as pessoas responderem que não, mas se responderem que sim, tente obter informações mais precisas)

(Imprimir a lista de palavras, a notícia e o trecho, todos abaixo, para mostrar ao informante)

\section{LISTA de PALAVRAS:}

Apresentar ao informante a lista de palavras e dizer: "Agora eu queria te pedir pra ler algumas coisas. Eu tenho aqui uma lista de palavras, e eu queria que você lesse cada uma delas. Você pode dar uma olhada primeiro, antes de começar a ler." Esperar que o informante leia a lista de palavras, depois perguntar:

1. A gente estava falando de sotaques agora há pouco... Como você acha que uma pessoa de São Paulo falaria algumas dessas palavras? Tem diferenças?

2. E como um carioca falaria algumas dessas palavras?

3. Tem mais algum sotaque no Brasil que você conhece que falaria essas palavras de formas diferentes?

\section{LEITURA DE NOTÍCIA:}

Dizer ao informante: "Agora eu queria que você lesse esse texto. Você pode ler antes de falar em voz alta." Esperar que o informante leia a notícia.

\section{LEITURA DE TRECHO:}

Dizer ao informante: "Por último, queria que você lesse esse trechinho." Esperar que o informante leia o trecho. 
1. O que você acha desse modo de falar: “(V)Ocê fica sem ter o que fazer" (sem a pronúncia do v de "você" e com r retroflexo exagerado). Se a pessoa manifestar uma atitude negativa, perguntar: Como você acha que deveria ser? O que tem de errado aî?

2. Quem você acha que fala assim? (se falar "mineiros", perguntar: "você acha que todos os mineiros falam assim ou é uma coisa de uma cidade mais específica no estado?").

3. Você fala desse modo?

4. E o que você acha de "O copim de vidro quebrou" (com -nho reduzido a $-\mathrm{m}$; Fazer as mesmas perguntas acima)?

5. E o que você acha de "A porta tá aberta." (com retroflexo exagerado). Fazer as mesmas perguntas acima.

6. E tem mais algum modo de falar que você acha assim bem mineiro (itanhanduense)? 


\section{Lista de palavras}

alma

amargo

está plantando

argola

atitude

barqueiro

biscoito

caldo

carteiro

cerca

chácara

circo

cisne

curto

defender

pouquinho

elefante

varal

entender

entretenimento

erguer

fazenda

mortalha

firme

fornalha

furgão

fusquinha

geleira

gérmen de trigo

gordo

potinho de amendoim

Hércules

pato irmã

pulso

lento

mortadela Marba

mosca

necessidade

está malhando

orca

Ordem e progresso

orgânico

órgão

ostracismo

penteado

pertencimento

perto

porto

pentear

rapidez

estou fazendo

sabor de menta

soberba

trabalho

turco

urgente

tralha

vulto

zebra 


\section{Noticia}

Boletim Informativo da Prefeitura Municipal

Itanhandu, $1^{\circ}$ a 15 de novembro de 2007.

\section{Saneamento Básico}

\section{O governo Mauricio Ordine faz o melhor pelos Itanhanduenses}

Nunca se avançou tanto em obras de infraestrutura em Itanhandu, como nas de saneamento básico, realizadas pela prefeitura municipal que beneficiam, hoje, cerca de 1.200 pessoas no bairro Jardim e 12.000 habitantes que moram no perímetro urbano da cidade. Com a ampliação da ETA (Estação de Tratamento de Água) do Jardim, a municipal melhorou a qualidade do serviço prestado aos moradores.

Atualmente, são tratados 750 mil litros de água por dia, os quais passam por três etapas de purificação: filtragem, floculação e cloramento. A distribuição atende, além do Jardim, às comunidades dos Gonçalves, Padre Chiquinho e entorno da Pousada Vila Minas.

Já a ETA do Centro recebeu reforços nas estruturas, obras de contenção de encostas, troca de elementos filtrantes, e impermeabilização do elevado. 


\section{Depoimento}

Tá chovendo muito! Choveu tanto, tanto na semana passada que ficou uma piscina na minha casa. Ó, pra você ver: Molharam todos os armários, a cama, os colchões, tudo... Foi um sacrificio... O que a gente fez? Nós tivemos que erguer os móveis pra limpar tudo: a geladeira, o forno... minha irmã até veio me ajudar, sabe? E meus filhos compraram umas cadeiras novas, mas é aquela coisa, assim... quando chover de novo, vai molhar tudo outra vez. Você fica sem ter o que fazer. E tem um rio lá perto que sempre alaga... quer dizer, é água dentro e fora de casa! Daí, o que acontece? Fica aquele trânsito, os carros todos parados, a gente demora um tempão pra chegar em casa... Não aguento mais enchente nessa cidade... Agora que eu vou fazer? Os políticos falam, falam, mas eles tinham que fazer alguma coisa urgente. Você tá entendendo o que eu tô dizendo? 


\section{ANEXO II}

\section{FICHA DO INFORMANTE}

Documentador:

Nome do Informante:

Idade:

Pseudônimo:

Data de Nascimento:

Endereço:

Telefones para contato:

Ocupação:

Pessoas com quem mora:

Cidades em que já morou (indicar aproximadamente quanto tempo morou em cada cidade):

Escolas em que estudou:

Fundamental 1:

Fundamental 2:

Ensino Médio:

Faculdade:

Número de irmãos: ( ) mais velhos ( ) mais novos 
Nome, idade e escolaridade dos irmãos:

Nome do Pai:

Idade do Pai:

Grau de Escolaridade do Pai:

Ocupação do pai:

Natural de: ( ) Itanhandu( ) Outros

Nome da Mãe:

Idade da Mãe:

Grau de Escolaridade da Mãe:

Ocupação da mãe:

Natural de: ( ) Itanhandu ( ) Outros

Data da Entrevista:

Horário:

Local da Entrevista e breve descrição do local:

Como o documentador conheceu o informante: 
Grau de relação entre informante e documentador:

( ) Bastante próximo. O entrevistado faz parte do meu círculo imediato de amigos/familiares e conversamos frequentemente.

( ) Próximo. Conversamos frequentemente, mas o entrevistado não faz parte do meu círculo imediato de amigos/familiares.

( ) Próximo, mas não conversamos frequentemente.

( ) Neutro. Ele é meu conhecido, mas não nos falamos com frequência.

( ) Distante. Não o conhecia anteriormente e praticamente só conversamos na ocasião da entrevista.

Outras informações relevantes: 


\section{ANEXO III}

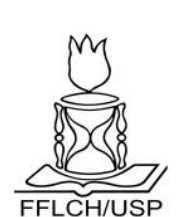

UNIVERSIDADE DE SÃO PAULO

FACULDADE DE FILOSOFIA, LETRAS E CIÊNCIAS HUMANAS

Av. Prof. Luciano Gualberto, 403 - Cx. Postal: 26097 - CEP: 01060970 - São Paulo

Fone: (011) 3091.4298 - e-mail: fll@usp.br

\section{Declaração}

Declaro ter consentido em gravar minha conversa com o aluno universitário Mariane Esteves Bieler da Silva. Entendo que essa gravação é idônea e que meus dados pessoais não serão tornados públicos.

Itanhandu, de de

(nome legivel e assinatura) 


\section{ANEXO IV}

Critérios gerais adotados na transcrição das 36 entrevistas sociolinguísticas que formam o corpus de Itanhandu - MG.

\begin{tabular}{|c|c|}
\hline Letras & $\begin{array}{l}\text { Transcreve-se toda a gravação em letras minúsculas, exceto nos } \\
\text { casos especificados abaixo. }\end{array}$ \\
\hline $\begin{array}{l}\text { Nomes próprios de } \\
\text { pessoas não públicas }\end{array}$ & $\begin{array}{l}\text { Indica-se apenas a inicial em maiúscula, seguida de ponto. } \\
\text { Exemplo: para indicar "Mariana", escreve-se M. }\end{array}$ \\
\hline $\begin{array}{l}\text { Nomes próprios de } \\
\text { pessoas públicas }\end{array}$ & $\begin{array}{l}\text { Deve-se transcrevê-lo completamente. Exemplo: "quando o Lula se } \\
\text { reelegeu...". }\end{array}$ \\
\hline Demais nomes próprios & $\begin{array}{l}\text { Transcreve-se por extenso, normalmente: Rio Grande do Sul, São } \\
\text { Paulo, Banco do Brasil, etc. }\end{array}$ \\
\hline Pontuação & $\begin{array}{l}\text { Não se usam ponto final e vírgula. Ponto de exclamação e ponto de } \\
\text { interrogação deve-se usar para indicar a entonação de certas } \\
\text { sentenças. }\end{array}$ \\
\hline Linhas & $\begin{array}{l}\text { Pula-se apenas uma linha para indicar a mudança de turno de } \\
\text { fala. }\end{array}$ \\
\hline Palavras estrangeiras & $\begin{array}{l}\text { Deve-se transcrevê-las sempre de acordo com a ortografia padrão } \\
\text { da lingua utilizada. } \\
\text { Exemplo: "eu gosto bastante de Friends... CSI..." }\end{array}$ \\
\hline Silabação & $\begin{array}{l}\text { Digita-se [silab.] logo após a palavra que sofreu silabificação. } \\
\text { Exemplo: "ele ficou apavorado [silab.]" }\end{array}$ \\
\hline Incerteza & $\begin{array}{l}\text { Se houver incerteza quanto ao que o falante pronunciou, digita-se } \\
\text { a palavra ou expressão entre parênteses. Além disso, coloca-se } \\
\text { entre parênteses sons que foram apagados pelo informante. } \\
\text { Exemplo: "(hoje em dia) a situação em São Paulo" } \\
\text { Exemplo: "(v)ocê não vê mais isso hoje". }\end{array}$ \\
\hline Inaudivel & Quando não se entende o que foi falado, indica-se por (xxx). \\
\hline Truncamentos & $\begin{array}{l}\text { Indica-se por / (barra) após a última sílaba da palavra proferida. } \\
\text { Ex.: "ca/ cachorro" }\end{array}$ \\
\hline Dados contextuais & $\begin{array}{l}\text { Deve-se notificá-los entre colchetes ([ ]). Exemplos: } \\
\text { [risos], [ruído], [tosse], etc. }\end{array}$ \\
\hline Hesitação & Indica-se por [hes.]; o uso de “eh" também indica hesitação. \\
\hline Sobreposição de vozes & $\begin{array}{l}\text { Os trechos em que há sobreposição de vozes devem vir entre } \\
\text { chaves (\{\}). Exemplo: } \\
\text { S1: "o Rio é maravilhoso... \{sempre gostei de ver o Rio nas\} } \\
\text { imagens da novela da Globo... } \\
\text { D1: \{você já esteve lá?\}" }\end{array}$ \\
\hline Pausas curtas & Deve-se indicá-las por reticências (...) \\
\hline $\begin{array}{l}\text { Pausas longas (acima de } 3 \\
\text { segundos) }\end{array}$ & $\begin{array}{l}\text { Além das reticências, deve-se especificar a duração em segundos } \\
\text { entre colchetes (... [ ]). } \\
\text { Exemplo: "deixa eu ver...[7] não acho que não" }\end{array}$ \\
\hline $\begin{array}{l}\text { Interjeições e marcadores } \\
\text { conversacionais }\end{array}$ & 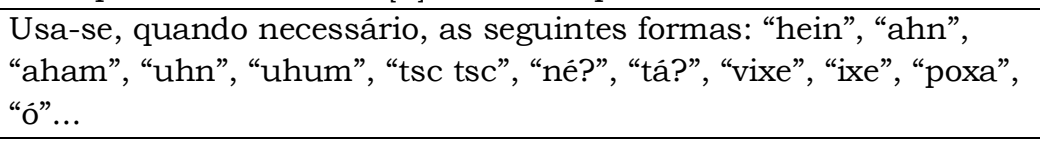 \\
\hline
\end{tabular}

